\title{
Soils and Rocks
}

An International Journal of Geotechnical and Geoenvironmental Engineering 


\section{SOILS and ROCKS}

\section{An International Journal of Geotechnical and Geoenvironmental Engineering}

Editor André Pacheco de Assis - University of Brasilia, Brazil

Co-editor Manuel Matos Fernandes - University of Porto, Portugal

Márcio Muniz de Farias University of Brasilia, Brazil

João Maranha

LNEC, Portugal

H. Einstein

MIT, USA

John A. Hudson

Imperial College, UK

Kenji Ishihara

University of Tokyo, Japan

Michele Jamiolkowski

Studio Geotecnico Italiano, Italy

Willy A. Lacerda

COPPE/UFRJ, Brazil

Claudio P. Amaral

Pontifical Catholic University, Brazil

Roberto F. Azevedo

Federal University of Viçosa, Brazil

Nick Barton

Consultant, Norway

Richard J. Bathurst

Royal Military College of Canada

Frederick Baynes

Baynes Geologic Ltd., Australia

Pierre Bérest

LCPC, France

Omar Y. Bitar

IPT, Brazil

Helmut Bock

$Q+S$ Consult, Germany

Laura Caldeira

LNEC, Portugal

Tarcisio Celestino

University of São Paulo-SC, Brazil

António S. Cardoso

University of Porto, Portugal

Chris Clayton

University of Surrey, UK

António G. Coelho

Consultant, Portugal

Nilo C. Consoli

Federal Univ. Rio Grande do Sul, Brazil

António G. Correia

University of Minho, Portugal

Rui M. Correia

LNEC, Portugal

Roberto Q. Coutinho

Federal Univ. of Pernambuco, Brazil

António P. Cunha

LNEC, Portugal

\section{Executive Board}

Fernando Schnaid

Federal Univ. Rio Grande do Sul, Brazil

\section{Associate Editors}

E. Maranha das Neves

Lisbon Technical University, Portugal

Nielen van der Merve

University of Pretoria, South Africa

Paul Marinos

NTUA, Greece

James K. Mitchell

Virginia Tech., USA

Lars Persson

SGU, Sweden

\section{Editorial Board Members}

R. Jonathan Fannin

University of British Columbia, Canada

Sérgio A.B. Fontoura

Pontifical Catholic University, Brazil

Roger Frank

LCPC, France

Maria H.B.O. Frascá

IPT, Brazil

Carlos D. Gama

Lisbon Technical University, Portugal

Vinod Garga

University of Ottawa, Canada

Nuno Grossmann

LNEC, Portugal

Richard J. Jardine

Imperial College, UK

Milton Kanji

University of São Paulo, Brazil

Peter Kaiser

Laurentian University, Canada

Luís L. Lemos

University of Coimbra, Portugal

José V. Lemos

LNEC, Portugal

Serge Leroueil

University of Laval, Canada

Robert Mair

University of Cambridge, UK

Mario Manassero

Politécnico di Torino, Italy

He Manchao

CUMT, China

João Marcelino

LNEC, Portugal

António C. Mineiro

New University of Lisbon, Portugal
Jorge Almeida e Sousa

University of Coimbra, Portugal

Harry G. Poulos

University of Sidney, Australia

Niek Rengers

ITC, The Netherlands

Fumio Tatsuoka

Tokyo University of Science, Japan

Luiz González de Vallejo

UCM, Spain

Teruo Nakai

Nagoya Inst. Technology, Japan

Claudio Olalla

CEDEX, Spain

Antonio M.S. Oliveira

University of Guarulhos, Brazil

Ennio M. Palmeira

University of Brasilia, Brazil

José D. Rodrigues

Consultant, Portugal

R. Kerry Rowe

Queen's University, Canada

Rodrigo Salgado

University of Purdue, USA

Sandro S. Sandroni

Consultant, Brazil

Luís R. Sousa

University of Porto, Portugal

Fabio Taioli

University of São Paulo, Brazil

Luis Valenzuela

Consultant, Chile

Ricardo Vedovello

São Paulo Geological Institute, Brazil

Andrew Whittle

MIT, USA

Jorge G. Zornberg

University of Texas/Austin, USA

Lázaro V. Zuquette

University of São Paulo, Brazil 
Soils and Rocks publishes papers in English in the broad fields of Geotechnical Engineering, Engineering Geology and Geoenvironmental Engineering. The Journal is published in April, August and December. Subscription price is US $\$ 90.00$ per year. The journal, with the name "Solos e Rochas", was first published in 1978 by the Graduate School of Engineering, Federal University of Rio de Janeiro (COPPE-UFRJ). In 1980 it became the official magazine of the Brazilian Association for Soil Mechanics and Geotechnical Engineering (ABMS), acquiring the national character that had been the intention of its founders. In 1986 it also became the official Journal of the Brazilian Association for Engineering Geology and the Environment (ABGE) and in 1999 became the Latin American Geotechnical Journal, following the support of Latin-American representatives gathered for the Pan-American Conference of Guadalajara (1996). In 2007 the journal acquired the status of an international journal under the name of Soils and Rocks, published by the Brazilian Association for Soil Mechanics and Geotechnical Engineering (ABMS), Brazilian Association for Engineering Geology and the Environment (ABGE) and Portuguese Geotechnical Society (SPG). In 2010, ABGE decided to publish its own journal and left the partnership.

\section{Soils and Rocks}

$\begin{array}{ll}1978, & 1(1,2) \\ 1979, & 1(3), 2(1,2) \\ 1980-1983, & 3-6(1,2,3) \\ 1984, & 7 \text { (single number) } \\ 1985-1987, & 8-10(1,2,3) \\ 1988-1990, & 11-13 \text { (single number) } \\ 1991-1992, & 14-15(1,2) \\ 1993, & 16(1,2,3,4) \\ 1994-2010, & 17-33(1,2,3) \\ 2011, & 34(1,2,3,4) \\ 2012, & 35(1,2,3) \\ \mathbf{2 0 1 3}, & \mathbf{3 6}(\mathbf{1}, \mathbf{2}, \mathbf{3})\end{array}$

ISSN 1980-9743 C CDU 624.131.1 
ISSN 1980-9743

\section{SOILS and ROCKS}

An International Journal of Geotechnical and Geoenvironmental Engineering

\section{Publication of}

\section{ABMS - Brazilian Association for Soil Mechanics and Geotechnical Engineering SPG - Portuguese Geotechnical Society Volume 36, N. 3, September-December 2013}

\section{Table of Contents}

ARTICLES

Universal Classification for the Use of Lateritic Soils in Low Cost Durables Pavements

J.K.G. Rodrigues, P. Reiffsteck, J.C. Auriol, M. Ndiaye

Dewatering Sludge in Geotextile Closed Systems: Brazilian Experiences

M.G.A. Guimarães, D.C. Urashima

Surprising Soil Behaviour in Soil Sampling

G.M.F. Jannuzzi, F.A.B. Danziger, I.S.M. Martins

Remediation Techniques Applied in Residual Clayey Soil (Oxisol) Contaminated by Diesel and Biodiesel L.R.R. Meneghetti, A. Thomé, F. Schnaid, L.M. Colla

Behavior of Clay-Tire Mixtures Subjected to Undrained Monotonic Loading

H. Soltani-Jigheh, V. Marefat, A. Ersizad

Numerical Analysis of El-Agrem Concrete Face Rockfill Dam

B. Moussai

Numerical Analysis of Reinforcement Strains at Failure for Reinforced Embankments over Soft Soils E.F. Ruiz, P.S. Hemsi, D.M. Vidal

TECHNICAL NOTE

Cadmium Transport Parameters in a Clayey Residual Soil with Different Values of Contaminant pH A. Thomé, E.P. Korf, R.S. Tímbola, N.C. Consoli 

Articles

\section{Soils and Rocks \\ v. 36, n. 3}





\title{
Universal Classification for the Use of Lateritic Soils in Low Cost Durable Pavements
}

\author{
J.K.G. Rodrigues, P. Reiffsteck, J.C. Auriol, M. Ndiaye
}

\begin{abstract}
The literature review of previous studies and the analysis of observations and knowledge gathered in Africa, as well as regional experience in Brazil, India and Australia on the influences of texture, grain size distribution and mineralogy conditions on the stability of materials used in pavement base have shown that the mechanical behaviour of lateritic soils is strongly influenced by their physical and mineralogical properties, we argue in this article that development of new procedures for classification of these soils as new building materials, that consider appropriate designs for the humid tropics and the nature and state parameters associated with the mechanical behaviour, can broaden the use of a higher percentage of local soils in pavement layers for low cost road compared to traditional techniques.
\end{abstract}

Keywords: lateritic soils, classification, low volume road.

\section{Introduction}

The difficulty in classifying tropical soils located in areas where "the laterization process" has a vital importance on their physical, chemical and mechanical properties is in the inability of traditional systems to correctly predict the mechanical behaviour of materials under the action of traffic and the environment. Classification systems such as those developed by the American Association of State Highway and Transportation Officials (AASHTO) and the Unified Soil Classification System (USCS) are not relevant when applied to some of these soils. Studies and practices have shown that recommendations based on these systems, particularly the activity of the clay fraction in the presence of water and the long term performance of gravel and sand fractions are not compatible with the results from the field and laboratory.

In this paper we analyze, from the Brazilian, Indian and Australian national experience and transnational experience on the African continent the influence of texture, grain size and mineralogy on the stability and classification of materials used in low costs pavement base. A new procedure for classification of lateritic soils is proposed.

\section{Laterization Process}

The laterization process includes a set of phenomena that lead to a considerable degree of weathering of bedrock soil, and an identification of items such as silica and oxide hydrates or hydroxides and metal, especially iron, aluminium, manganese and titanium (Maignein, 1966).

This process may be followed by other soil processes such as dragging hydroxides from the surface to a halfdepth horizon; hardening in concretions or shells or armor of metal hydroxides previously individualized and some- times accumulated; segregation of elements of an horizon by hydromorphy (Autret, 1983; Schellmann, 2009).

\subsection{Influence factors}

Factors that influence the laterization process are climate, topography, vegetation, bedrock, the dragging period with optimization by the drainage conditions (Autret, 1983).

\subsection{Geographic location of lateritic soil distribution}

A global census conducted by FAO shows that the lateritic soil distribution is localized in tropical regions (South America, Africa, India, Australia and South East Asia) (Fig. 1) FAO (2006). It is therefore mainly in developing countries where the issue of transport infrastructure development is vital.

\subsection{Product release "lateritic systems"}

Lateritic soil to be used in civil engineering is characterized by a high degree of alteration of minerals from the original rock with virtual elimination of alkaline and alkaline-earth, and partial silica; thrust decomposition of organic matter and a accumulation of more or less hydroxides and oxides of $\mathrm{Fe}, \mathrm{Al}, \mathrm{Ti}, \mathrm{Mn}$. To this may be added, at varying degrees, the accompanying leaching process, accumulation of organic matter and induration (Schellmann, 2009).

\subsection{Chemical composition of lateritic soil}

Lateritic soils contain as chemical components, a high percentage of oxides and hydroxides of $\mathrm{Fe}$ and $\mathrm{Al}$ (oxides and hydroxides of iron and / or alumina - sesquioxides) for some Gravelly lateritic soils up to near $80 \%$ of laterization process product.

J.K.G. Rodrigues, PhD, Associate Professor, Universidade Federal de Campina Grande, 58402-000 Campina Grande, PB, Brazil. e-mail: jkennedy@pq.cnpq.br. P. Reiffsteck, PhD, Professor, Université Paris Est/IFSTTAR-LCPC, 75732 Paris, France. e-mail: philippe.reiffsteck@lcpc.fr.

J.C. Auriol, PhD, Professor, IFSTTAR-LCPC - Nantes. Address : 58, Boulevard Lefebvre - 75732 Paris Cedex 15, France. e-mail: jean-claude.auriol@ lcpc.fr. M. Ndiaye, PhD Student, Ecole Centrale de Paris, 75732 Paris, France. e-mail: massam14ba@yahoo.fr.

Submitted on August 30, 2011; Final Acceptance on April 8, 2013; Discussion open until April 30, 2014. 


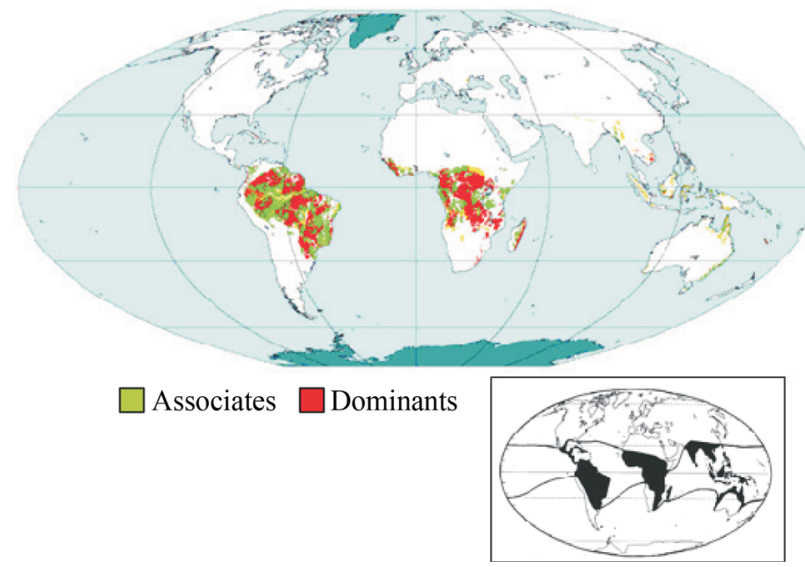

Figure 1 - Lateritic soil distribution (Ferralsols) over the world FAO (2006).

These components are generally in lateritic soils, regardless of specific behaviours, specific of clay minerals observed under tempered climate. Thus, although having a high surface area and small size, they do not present a swelling behaviour, have a significant cation exchange capacity in the $\mathrm{pH}$ conditions prevailing in these soils and have an excess of positive charges (not negative as in the case of clay minerals) (Villibor \& Nogami, 2009).

It is possible to observe the microstructure of fine grains lateritic soils using scanning electron microscopy (SEM). The presence of relatively large flakes, caking clay particles, having the appearance of "clouds" or "popcorn" and measuring from 1 to 2 to 50 to $100 \mathrm{~mm}$ in their largest dimension is observed (Fig. 2).

\section{Morphology of Lateritic Soils}

The induration of samples depends on factors such as degree of crystallization of components, assembly of the various constituents and the degree of aging.

The extremely varied structure can be reduced to three main types: hardened elements form an consistent and continuous skeleton, indurated elements as concretions or nodules free in the middle of an earth mass and hardened elements cement the pre-existing materials.

Their pigmentation is due to iron oxides more or less hydrated and sometimes manganese. The color of the soil is mixed but generally of strong intensities. The most common colors are: pink, red, yellow, brown and ocher.

The density varies in relatively large proportions (2.5 to 3.6) and depends on the chemical composition of lateritic soil. It increases with iron content and decreases with the concentration of alumina. Oxidized forms are denser than the hydrated forms.

The evolution of rock from inner to surface is characterised by different sets overlapping each other allowing to generally distinguish a set of weathering, a intermediate set of overall accumulation of metal oxyhydroxides and clay phases and a set of washed up upper crust of residual primary minerals resistant.

\section{Pedogenic Classifications}

Lateritic soils can be classified in a synthetic or analytic manner. The first classification is based on genetic factors and on properties of factors or pedogenic processes. The second considers mainly morphological characters, including pedogenic concerns (Maignein, 1966). The main denominations are: Laterite, tropical soils, lateritic soils, ferruginous soils, lateritic soils, Soil Ferseallitiques, ferrisols, Ferrasol, Andosols, Oxisols, Podzols, Latossols and Plinthosols.

\section{Geotechnical Classification}

\subsection{Particle size ditribution}

The particle size distribution of lateritic soils generally has:

- A high proportion of fines (below $80 \mu \mathrm{m}$ sieve) from 10 to $40 \%$;

- A refusal on the $2 \mathrm{~mm}$ sieve from 20 to $60 \%$;

- A variable hardness of gravels in the same deposit and this depending on the maturity of lateritic particles concretionned and the amount of sesquioxide which predominates in the aggregate; (a)

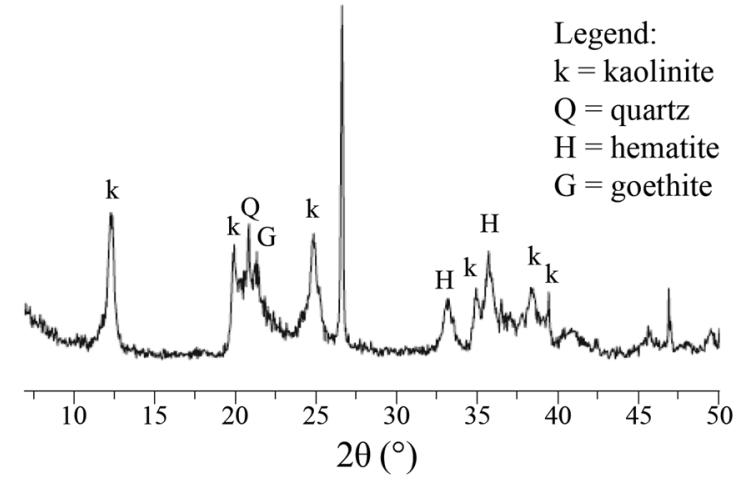

(b)

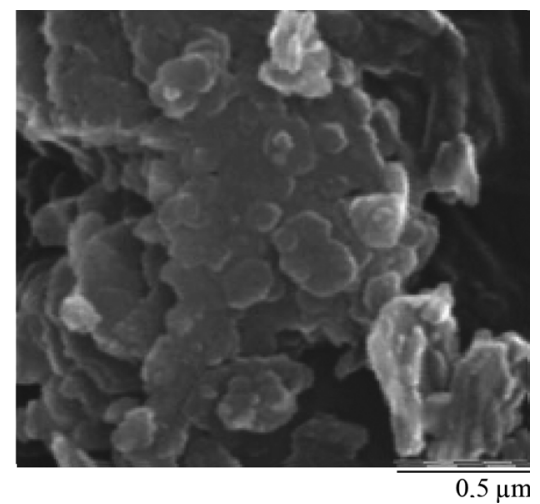

Figure 2 - Test results for lateritic soils (a) X-ray diffraction (b) SEM LNEC (2009). 
- The grading curves present frequently a step or a curvature indicating the absence of certain granular fractions. This step is between 8 and $0.2 \mathrm{~mm}$;

- Materials with hard aggregates, rich in iron, tend to have stable mechanical behaviour;

- In the granular fraction, the mineralogical composition of the silt fraction is generally simple, the predominance of quartz with the presence of lumps of clay appear clearly;

- The main constituents of the clay fraction (diameter less than $0.002 \mathrm{~mm}$ ) can be classified as: clay minerals, oxides and hydroxides of iron and / or aluminium, and organic constituents.

\subsection{Influence of test methodology on particle size distri- bution}

The metastable structure of lateritic soils is sensitive to changes in levels of thermal energy and therefore its physical properties. In terms of size, drying causes an increase in the size of the particles, leading clayey fraction and silt fraction to agglomerate up to the granulometry of a sand due to the coagulation of iron oxide during heating (Terzaghi, 1958; Moh \& Mazhar, 1969; Lyon, 1971).

For lateritic soils, increasing the mechanical energy results, due to its vulnerability, results in an increase of the apparent maximum dry density and content in fine sand, especially with the fraction in excess on the $80 \mu \mathrm{m}$ sieve and for fine soils which have a low clay content and a high $\mathrm{Fe}_{2} \mathrm{O}_{3}$ content (Novais \& Meireles, 1992).

\subsection{Plasticity limit}

The influence of sesquioxides $\left(\mathrm{Al}_{2} \mathrm{O}_{3}\right.$ and $\left.\mathrm{Fe}_{2} \mathrm{O}_{3}\right)$ made that lateritic soils have a plastic behaviour differed from that of soils under temperate climates. During the test, an increase of the surface area is observed due to the disintegration of particles and/or breakage of granular soil structure with consequently an increase of water absorption by

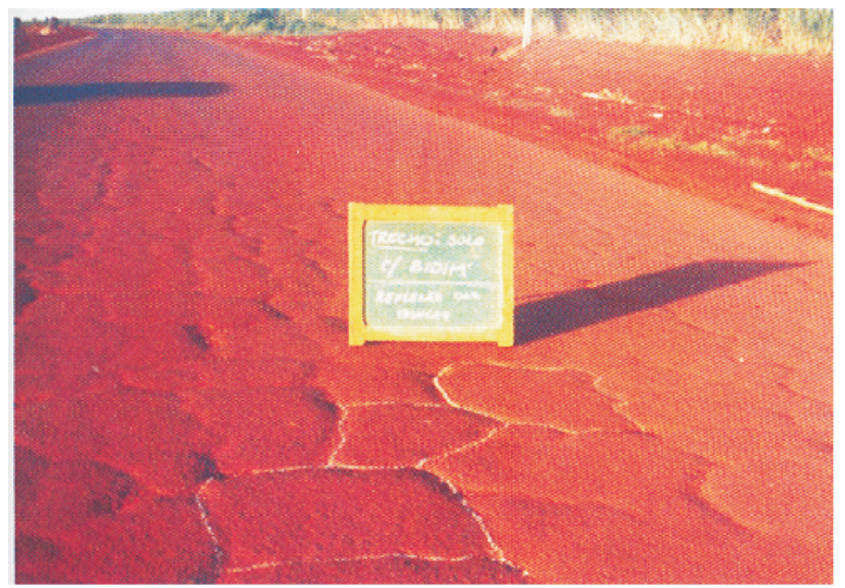

the sample (Moh \& Mazhar, 1969; Villibor \& Nogami, 2009).

\subsection{Shrinkage limit}

The knowledge of the shrinkage limit is important for predict whether lateritic soils, and especially their fine fractions, are unlikely to be subject, mainly in countries with well marked dry seasons, to shrinkage which could lead to cracking. It would then preferable to keep them safe from moisture changes or possibly not use them without improvement or stabilization (Fig. 3) (Autret, 1983).

\subsection{Durability}

The strength and durability of hardened laterite depends on their chemical composition, age and homogeneity. The iron-rich laterites hardened are harder than those that are rich in alumina (Lyon, 1971; Enuvie \& Hudec, 1992).

The results of measurements of specific gravity and absorption show a relationship with the durability of coarse particles. The durability of coarse elements increases with the weight. The behaviour of fine elements can be linked with the absorption and not with density. The durability of coarse and fine elements increases when the water absorption decreases.

\subsection{Compaction characteristics}

Factors influencing the properties of compacted lateritic soils can be separated into two groups (Lyon, 1971). The first group of these factors is related to soil genesis, the second relates to pre-treatment methods applied prior to testing. The factors are:

- Texture: the most important genetic factor;

- The influence of the transformation of hydrated halloysite méthalloysite result of the drying in the oven;

- Position of the sample in the soil profile (depth of the sample);

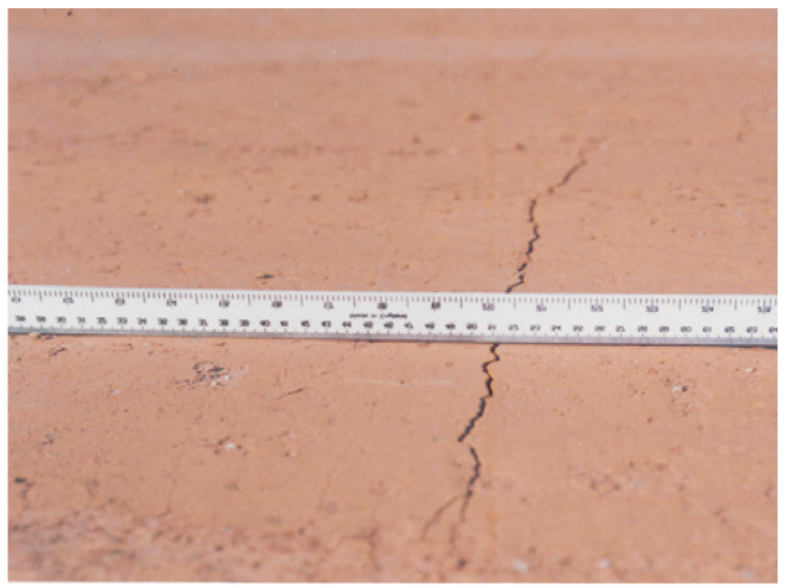

Figure 3 - Cracking on pavement made of fine and coarse lateritic soils (Villibor, 2009). 
- Erosion of concretionned lateritic gravel during compaction and the degree of laterization process maturity;

- For a given energy and for lateritic fine soils more than gravelly ones, drying in the oven always gives higher maximum dry density and lower optimum moisture content, while the soils at natural water content give the lowest maximum dry density and the highest optimum water content.

\subsection{Bearing characteristics}

For ISTED (1990) the stability and bearing capacity lateritic soils depend on:

- The maximum grain size D;

- The sieving of $80 \mu \mathrm{m}$;

- The residue on the sieve of $20 \mathrm{~mm}$;

- The step of the grading curve between $80 \mu \mathrm{m}$ and $2 \mathrm{~mm}$;

- Plasticity;

- The fragility of the nodules (changes during compaction) and;

- The mineral nature of fine particles.

\section{Classification System for Lateritic Soils Used in Low Cost Paving Platform}

Various studies show that it is possible to establish classification systems tailored to lateritic soils (Fall, 1953; Sharp et al., 2001) for use in low cost pavement based on the nature and state parameters as well mechanical properties. To do this, it is important that test execution are compatible with the specificities of soil in tropical regions, with measured reference values to be adopted, being consistent with the type of traffic on pavements (Villibor \& Nogami, 2009).

Figures 4 and 5 illustrates the logical sequence of a proposed classification for lateritic soils based on numerous literature reviews and using as inputs the parameters of nature and state and the mechanical behaviour measured during laboratory testing.

In this method two aspects are considered: first, the metastable structure of lateritic soils, sensitive to changes in levels of thermal and mechanical energy and secondly the physical and mineralogical properties (the influence of sesquioxides) compared to the resistance, durability and plasticity.

Soils are classified according to their plasticity and particle size (gravelly, sandy or fine soil). Finally, classes are established based on the mechanical behaviour from the test results on degradability, fragmentability, embrittlement, bearing capacity and shrinkage limit (Figs. 5 and 6).

At this stage of our study, the creation of a database of cases will allow the validation of this new classification. This will be done in the framework of an international cooperation.

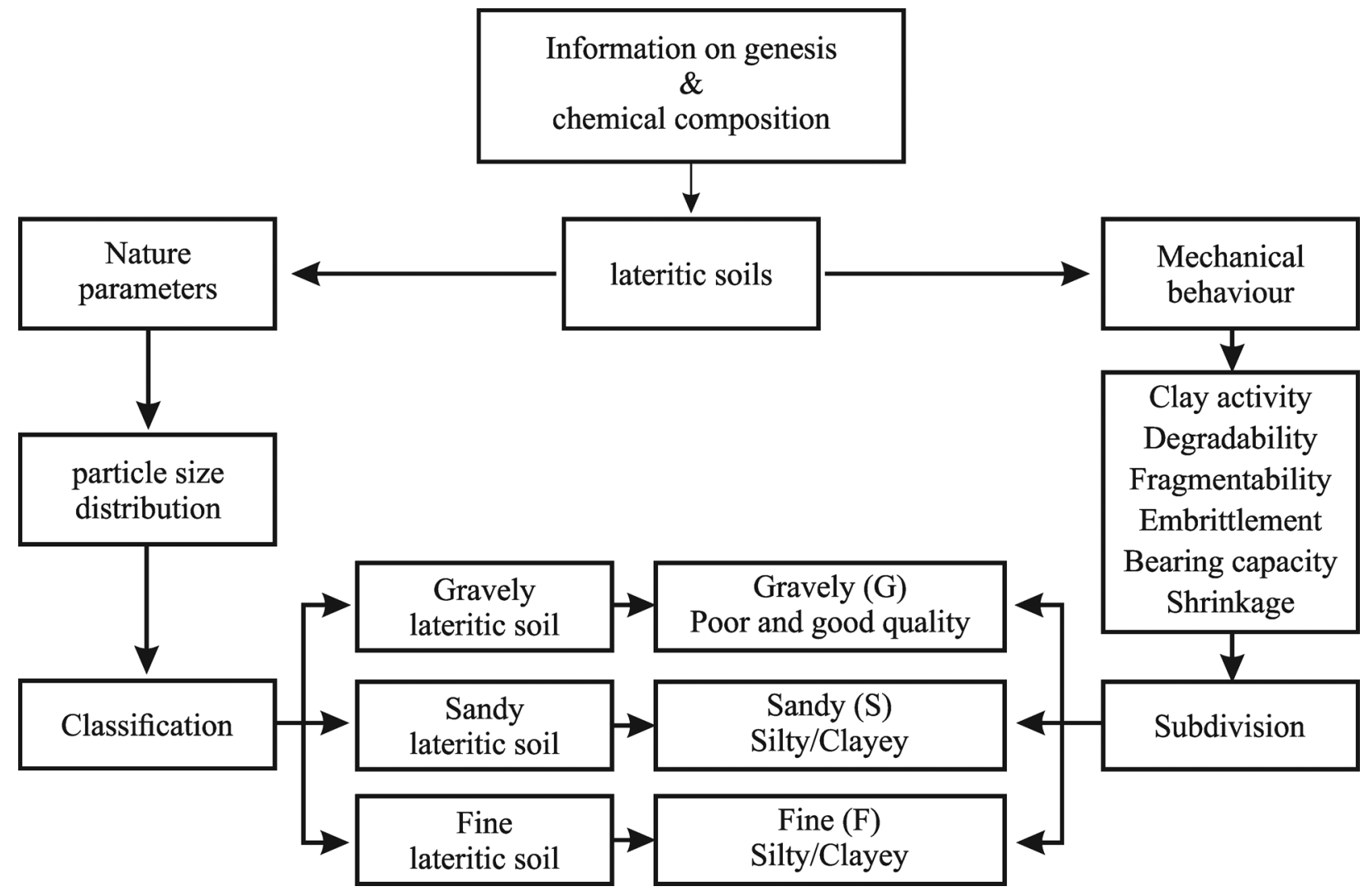

Figure 4 - Chart with the criteria for a proposed classification of lateritic soils. 


\section{Case Study}

For the case study we choose three soil samples from the Brazilian Northeast Region, based in previous knowledge on its materials' characteristics, on geographic localization and region's.

\subsection{Reservoir - Rio Grande do Norte State}

Located in the Metropolitan Region of Natal, more precisely in São Gonçalo of Amarante, the reservoir C is in the Natal's International Airport area which is used as sub-base of the airport's runway and taxi-in space.

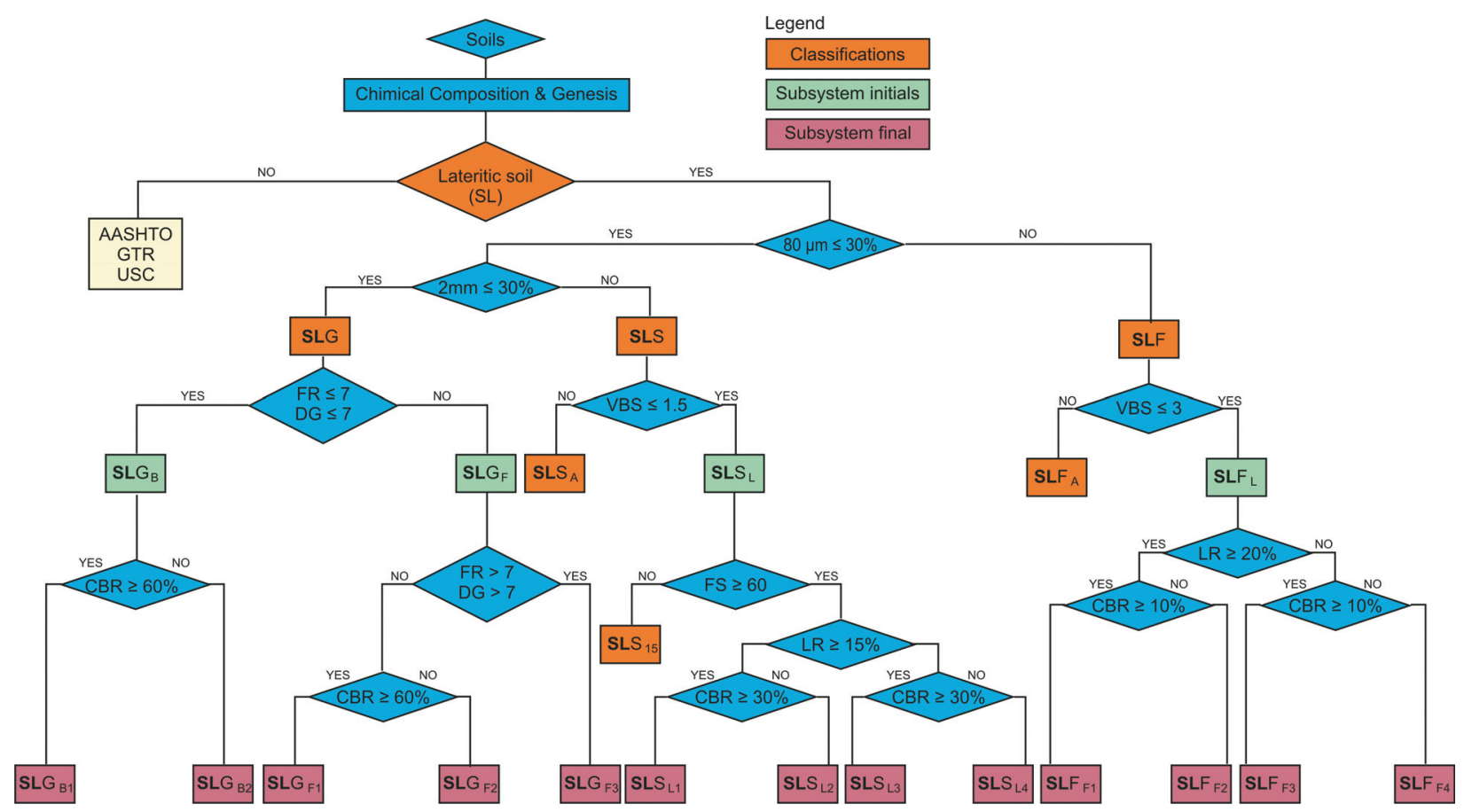

Figure 5 - Layout with the criteria for a proposed classification of lateritic soil.

\begin{tabular}{|c|c|c|c|c|c|c|c|c|c|c|c|c|c|c|c|}
\hline \multicolumn{16}{|c|}{$\begin{array}{l}\text { Lacteritic Soils (SL) } \\
\text { (Genesis and chemical compositions) }\end{array}$} \\
\hline \multicolumn{11}{|c|}{$80 \mu \mathrm{m} \leq 30 \%$} & \multirow{2}{*}{\multicolumn{5}{|c|}{$80 \mu \mathrm{m}>30 \%$}} \\
\hline \multicolumn{5}{|c|}{$2 \mathrm{~mm} \leq 30 \%$} & \multicolumn{6}{|c|}{$2 \mathrm{~mm}>30 \%$} & & & & & \\
\hline \multicolumn{5}{|c|}{ Gravely Lateritic Soils (SLG) } & \multicolumn{6}{|c|}{ Sandy Lateritic Soils (SLS) } & \multicolumn{5}{|c|}{ Fine Lateritic Soils (SLF) } \\
\hline \multicolumn{2}{|c|}{$\begin{array}{c}\mathrm{FR} \leq 7 \\
\& \\
\mathrm{DG} \leq 7\end{array}$} & \multicolumn{2}{|c|}{$\begin{array}{c}\mathrm{FR}>7 \\
\text { ou } \\
\mathrm{DG}>7\end{array}$} & \multirow{4}{*}{$\begin{array}{c}\mathrm{FR}>7 \\
\& \\
\mathrm{DG}>7\end{array}$} & \multicolumn{5}{|c|}{ VBS $\leq 1.5$} & \multirow{4}{*}{ VBS $>1.5$} & \multicolumn{4}{|c|}{ VBS $\leq 30 \%$} & \multirow{4}{*}{ VBS $>3$} \\
\hline \multirow{3}{*}{$\begin{array}{l}\text { CBR } \\
\geq 60 \%\end{array}$} & \multirow{3}{*}{$\begin{array}{c}\mathrm{CBR} \\
>60 \%\end{array}$} & \multirow{3}{*}{$\begin{array}{l}\text { CBR } \\
\geq 30 \%\end{array}$} & \multirow{3}{*}{$\begin{array}{c}10 \% \leq \mathrm{CBR} \\
\leq 30 \%\end{array}$} & & FS $\leq$ & & FS & 60 & \multirow{3}{*}{$\mathrm{FS}>60$} & & \multicolumn{2}{|c|}{ LR $\geq 20 \%$} & \multicolumn{2}{|c|}{$\mathrm{LR}<20 \%$} & \\
\hline & & & & & \multicolumn{2}{|c|}{$\mathrm{LR} \geq 15 \%$} & \multicolumn{2}{|c|}{ LR $<15 \%$} & & & \multirow{2}{*}{$\begin{array}{l}\text { CBR } \\
\geq 10 \%\end{array}$} & \multirow{2}{*}{$\begin{array}{c}\mathrm{CBR} \\
<10 \%\end{array}$} & \multirow{2}{*}{$\begin{array}{l}\text { CBR } \\
\geq 10 \%\end{array}$} & \multirow{2}{*}{$\begin{array}{l}\text { CBR } \\
<10 \%\end{array}$} & \\
\hline & & & & & $\begin{array}{c}\text { CBR } \\
\geq 30 \%\end{array}$ & $\begin{array}{l}\text { CBR } \\
<30 \%\end{array}$ & $\begin{array}{l}\text { CBR } \\
\geq 30 \%\end{array}$ & $\begin{array}{l}\text { CBR } \\
<30 \%\end{array}$ & & & & & & & \\
\hline $\mathrm{SLG}_{\mathrm{B} 1}$ & SLG $_{B 2}$ & $\mathrm{SLG}_{\mathrm{F} 1}$ & $\mathrm{SLG}_{\mathrm{F} 2}$ & SLG $_{\mathrm{F} 3}$ & SLS $_{\mathrm{LI}}$ & SLS $_{\mathrm{L} 2}$ & $\mathrm{SLS}_{\mathrm{L} 3}$ & SLS $_{\mathrm{L} 4}$ & SLS $_{L 5}$ & SLS $_{A}$ & $\mathbf{S L F}_{\mathrm{F} 1}$ & $\mathrm{SLF}_{\mathrm{F} 2}$ & $\mathrm{SLF}_{\mathrm{F} 3}$ & $\mathrm{SLF}_{\mathrm{F} 4}$ & $\mathrm{SLF}_{\mathrm{A}}$ \\
\hline $\begin{array}{r}1 \\
\text { treat }\end{array}$ & nent & $\begin{array}{l}\text { With } \\
\text { treatment }\end{array}$ & & & $\begin{array}{c}\text { No } \\
\text { treatment }\end{array}$ & & \multicolumn{4}{|c|}{ With treatment } & $\begin{array}{c}\text { No } \\
\text { treatment }\end{array}$ & \multicolumn{4}{|c|}{ With treatment } \\
\hline \multicolumn{5}{|c|}{ Base Layer $(\mathrm{CBR} \geq 60 \%)$} & \multicolumn{6}{|c|}{ Fondation Layer (CBR $\geq 30 \%$; LR $\geq 15 \%$ ) } & \multirow{5}{*}{\multicolumn{5}{|c|}{ Sub-Base Layer (CBR $\geq 10 \%$; LR $\geq 20 \%$ ) }} \\
\hline $\begin{array}{r}\mathrm{No} \\
\text { with }\end{array}$ & $\begin{array}{l}\text { treatment } \\
\text { CBR } \geq 30\end{array}$ & & With treatme & & $\begin{array}{r}\text { No tre } \\
\text { with CBI }\end{array}$ & $2 \geq 10 \%$ & & With & reatment & & & & & & \\
\hline & Fondatic & In Layer (CF & $3 \mathrm{R} \geq 30 \%$ & & & & & & & & & & & & \\
\hline & & No treatmen & & & & Sub-Base & Layer $(\mathrm{Cl}$ & $\mathrm{R} \geq 10 \%$ & $\mathrm{LR} \geq 15 \%$ & & & & & & \\
\hline Sub & Base Lay & $\mathrm{er}(\mathrm{CBR} \geq 1$ & $0 \% ; L R \geq 15$ & & & & & & & & & & & & \\
\hline $\begin{array}{l}\text { Observ } \\
\text { Traffic } \\
\text { SLG = } \\
\text { L = Silt } \\
\text { FR = F }\end{array}$ & $\begin{array}{l}\text { tions: } \\
=\mathrm{N}<10^{5} \\
\text { iravely La } \\
; \mathrm{A}=\mathrm{Clay} \\
\text { agmentabi }\end{array}$ & $\begin{array}{l}\mathrm{P}<13 \text { Tonn } \\
\text { teritic Soils; } \\
\text { rey; } \mathrm{F}=\text { poo } \\
\text { lity coefficie }\end{array}$ & $\begin{array}{l}\text { fes } \\
\text { SLS = Sandy } \\
\text { quality; B = } \\
\text { ent DG = Deg }\end{array}$ & $\begin{array}{l}\text { Lateritic } \\
\text { good qua } \\
\text { gradabilit }\end{array}$ & $\begin{array}{l}\text { Soils; SL } \\
\text { ality. } \\
\text { y coefficie }\end{array}$ & $\begin{array}{l}\mathrm{F}=\text { Fines } \\
\mathrm{nt} ; \mathrm{FS}=\mathrm{E}\end{array}$ & $\begin{array}{l}\text { teritic S } \\
\text { orittlem }\end{array}$ & $\begin{array}{l}\text { ils. } \\
\text { nt coeff }\end{array}$ & t; LR & rink & t; VB & lue $\mathrm{N}$ & len & & \\
\hline
\end{tabular}

Figure 6 - Proposition of a classification system for lateritic soil. 


\subsection{RC Reservoir - Pernambuco State}

The RC Reservatoir is located in the Recife's Metropolitan Region and was used as sub-base material of a highway pavement.

\subsection{PIC Reservoir- Piauí State}

The third reservatoir, called $P I C$, located $70 \mathrm{~km}$ of Picos City, at Highway 316 borders, among the cities of Inhuma and Ipiranga.

Results from X-Rays Diffraction Analysis of soils studied are shown in Fig. 7. The peaks shown in the diffractometer for the three soil samples indicate the presence of Quartzo $\left(\mathrm{SiO}_{2}\right)$ and of Kaolinite $\left(2 \mathrm{SiO}_{2} \mathrm{Al}_{2} \mathrm{O}_{3} 2 \mathrm{H}_{2} \mathrm{O}\right)$.

According to Nogami \& Villibor (1995), due to the lateritization process the clay fraction of lateritic soils is constituted essentialy by clay minerals of the Kaolinite Group and by oxides and hydroxides of Ferro and/or. Therefore results obtained with the help of diffraction tests indicate that the material we analyzed are probably lateritic soils.

The microphotographs of soils samples obtained in the Scanning Electron Microscopy (SEM) are show in

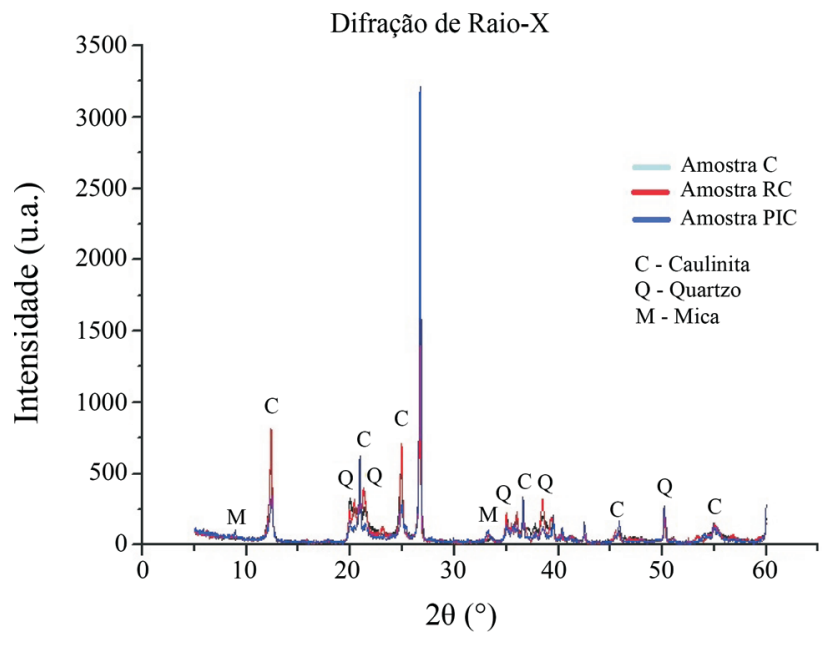

Figure 7 - Diffraction of X-rays - C Sample.

Fig. 8, regarding to sample $\mathrm{C}$; in the Fig. 9, regarding to sample, and int He Fig. 10, regarding to sample, with 1,000, 3,000, 5,000, 10,000 and 20,000 times magnification.

We observed typical patterns of materials which suffered the lateriticzation process, a marking characteristic of

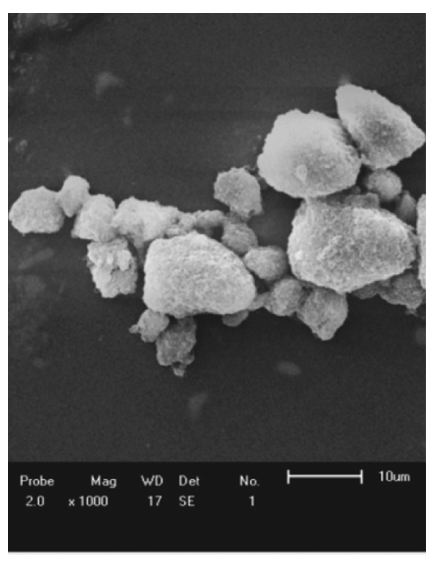

a) Ampliação de 1.000 vezes

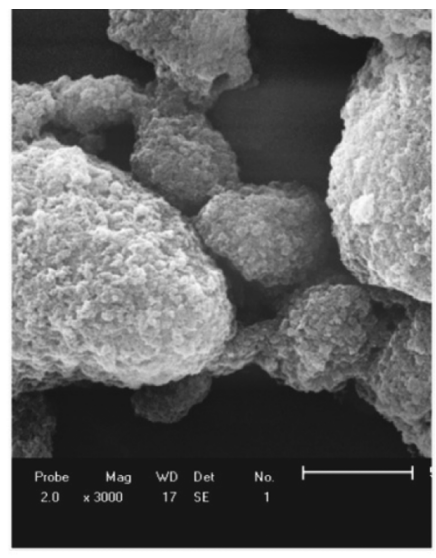

b) Ampliação de 3.000 vezes

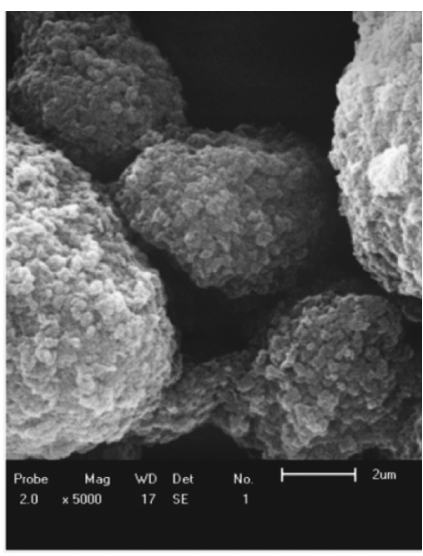

c) Ampliação de 5.000 vezes

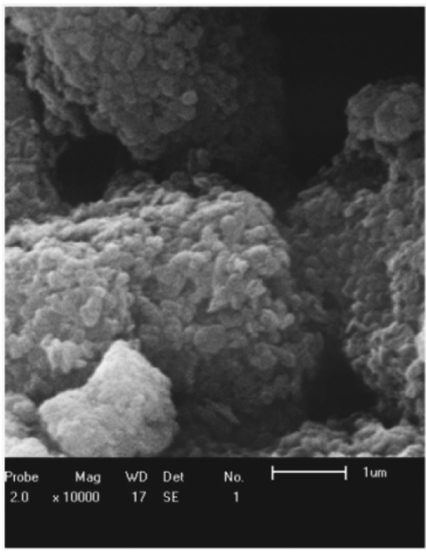

d) Ampliação de 10.000 vezes

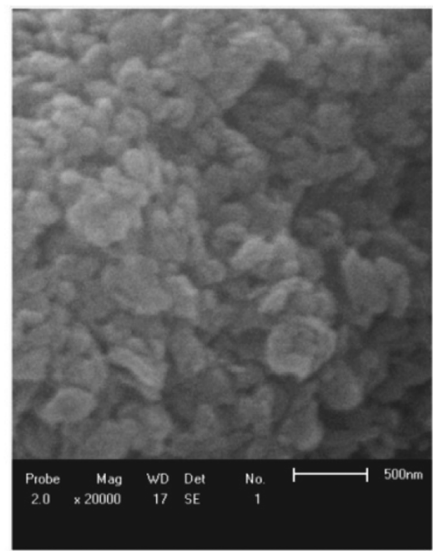

e) Ampliação de 20.000 vezes

Figure 8 - Microphotographs (MEV) of the C Sample. 


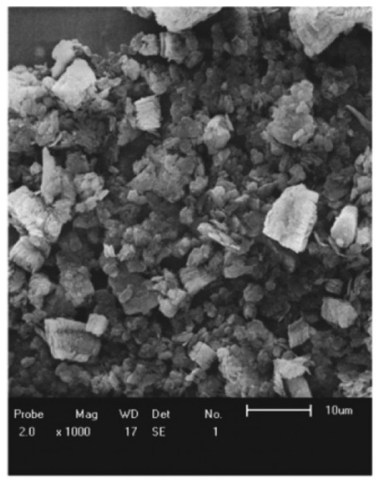

a) Ampliação de 1.000 vezes

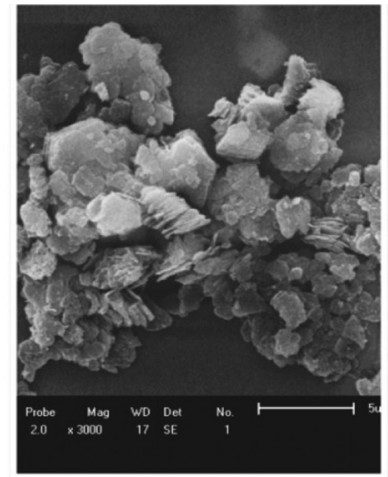

b) Ampliação de 3.000 vezes

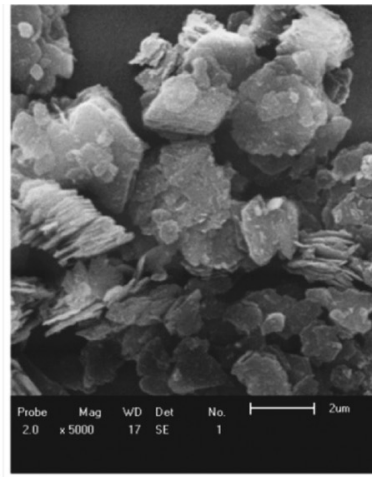

c) Ampliação de 5.000 vezes

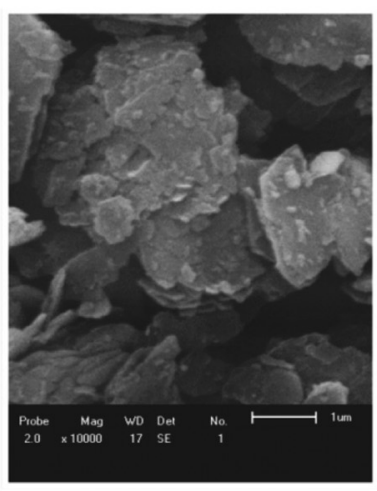

d) Ampliação de 10.000 vezes

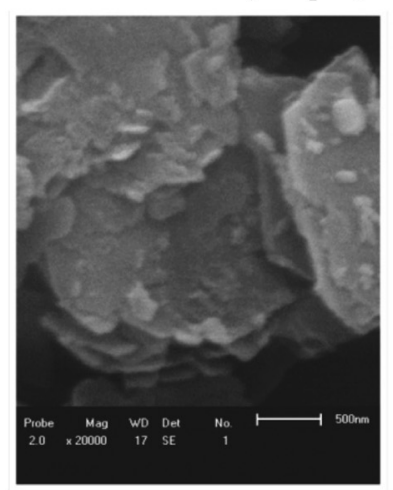

e) Ampliação de 20.000 vezes

Figure 9 - Microphotographs (MEV) of the RC Sample.

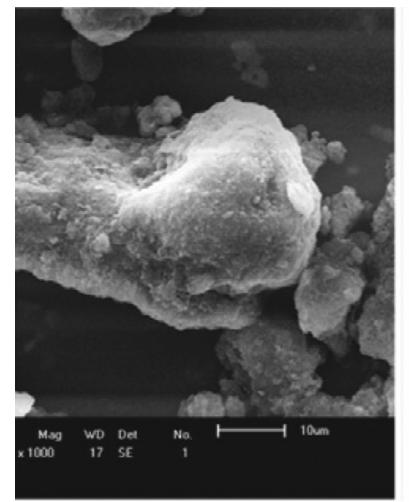

a) Ampliação de 1.000 vezes

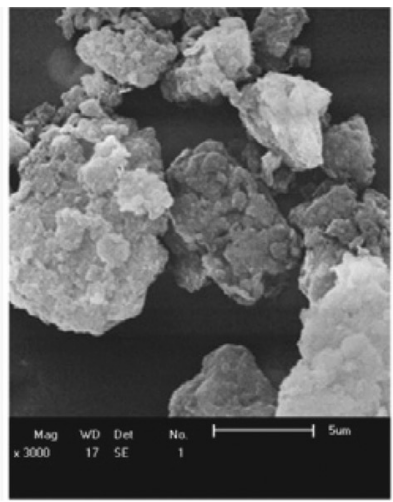

b) Ampliação de 3.000 vezes

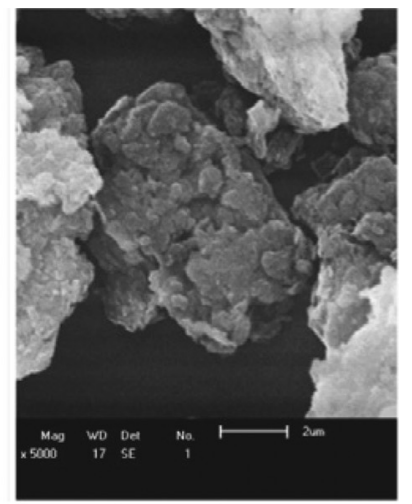

c) Ampliação de 5.000 vezes

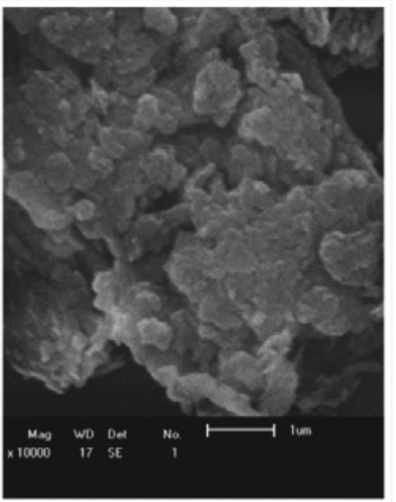

d) Ampliação de 10.000 vezes

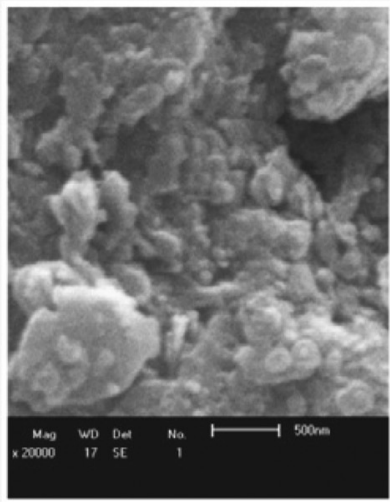

e) Ampliação de 20.000 vezes

Figure 10 - Microphotographs of PIC Sample. 
Table 1 - Universal soil classification parameters.

\begin{tabular}{lcccc}
\hline Laboratory test & & C sample & RC sample & PIC sample \\
\hline Brazilian standard & $\%<0.08 \mathrm{~mm}$ & 19.91 & 25.56 & 13.03 \\
& $\%<2.00 \mathrm{~mm}$ & 98.70 & 99.31 & 62.65 \\
\hline French standard & $\%<0.08 \mathrm{~mm}$ & 19.85 & 27.17 & 31.52 \\
& $\%<2.00 \mathrm{~mm}$ & 98.41 & 99.25 & 60.96 \\
\hline Fragmentability coefficient & & - & - & - \\
Degradability coefficient & & - & 1.4 & 2.0 \\
VBS (g/100 g) & & 31.8 & 37.4 & 71.7 \\
Embrittlement coefficient $(\%)$ & & 27.1 & 24.6 & 35.0 \\
Contraction limit $(\%)$ & 62.45 & 12.37 & 13.21 \\
CBR $(\%)$ & & - & \\
\hline
\end{tabular}

lateritic soils, due to its cemented appearance. There is a clear presence of quartzo and again the occurrence of an amorphous layer of Ferro and Aluminium oxides and hydroxides, involving the Kaolinite in the lateriticzation process.

Differences observed among images of C, RC and PIC samples were caused probably by soil reaction to the sample dispersion process or due to characteristics of the samples fractions we analyzed. According to the results obtained in the SEM there's no doubt the three samples have chemical composition compatible with soils whose origin is lateritic. In the RC soil one can clearly observe the Kaolinite clay mineral stacking in a hexagonal form.

\section{Classifications of Soils}

The Universal Soils Classification required parameters are presented in Table 1. The classification we produced is detailed in Table 2. In summary the soils we studied were classified as Sandy lateritic soils with high retraction and with middle to low bearing capacity. Therefore they need particle size or chemical in order to avoid fissures and to improve their bearing capacity when used in highways pavements as base and sub-base material.

Due to its high retraction and to its necessity of stabilization, results after stabilization procedures probably will be compatible with the demands of bearing capacity in layers of base and sub-base of low volume of traffic, being

Table 2 - Universal soils classification.

\begin{tabular}{ll}
\hline Sample & Lateritic universal lateritic soils classification \\
\hline C reservatoir & Sandy Lateritic Soil \\
& SLS $_{\mathrm{A}}$ \\
RC reservatoir & Sandy Lateritic Soil \\
& SLS $_{\mathrm{S} 2}$ \\
PIC reservatoir & Sandy Lateritic Soil / Fine Lateritic Soil \\
& SLS $_{\mathrm{A}} / \mathrm{FLS}_{\mathrm{S} 1}$ \\
\hline
\end{tabular}

unnecessary additional costs with the increase of the compacting energy.

\section{Conclusion}

The new classification procedure proposed takes into account the appropriate design criteria to the tropical humid climate, and the specific nature and state parameters associated with the mechanical behaviour of lateritic soils. It is expected to provide for much higher use of local soils in pavement layers. This study is part of a growth policy leading to saving resources and optimizing the lifecycle of infrastructure adapted for emerging countries.

\section{Acknowledgments}

The authors wish to thank the Laboratoire Central des Ponts et Chaussées (LCPC / France) and the Conselho Nacional de Desenvolvimento Cientifico e Tecnologico (CNPq / Brazil) for financial support for this research action.

\section{References}

Autret, P. (1983) Latérites et Graveleux Latéritiques. Phd Dissertation. Institut des Sciences et des Techniques de L'équipement et de L'environnement Pour le Développement, Laboratoire Central des Pontes et Chaussées, Paris, 120 p.

Akpokodje, E.G. \& Hudec P.P. (1992) Factors controlling properties and durability of laterite gravel aggregates. Journal of Materials in Civil Engineering, ASCE, v. 4:1, p. $58-70$.

Fall, M. (1993) Genèse et Formation des Sols Latéritiques. Phd Dissertation. Faculté des Sciences et TechniquesUCAD, Institut National Polytechnique de Lorraine, Nancy, 240 pp.

Food and Agriculture Organization of United Nation - FAO (2006). World Reference Base for Soil Resources, World Soil Resources Reports, Rome, 128 pp. 
ISTED (1990) Utilisation des Graveleux Latéritiques en Technique Routière. Synthèses. Institut des Sciences et des Techniques de l'Equipement et de l'Environnement Pour le Développement, Centre Expérimental de Recherches et D'Études du Bâtiment et des Travaux Plubics, Paris, 203 pp.

Lyon Associates Inc. (1971) Une Etude Géotechnique pour Agence pour le Développement International, Les Sols Latéritiques et d'Autres Sols Difficiles d'Afrique, Lyon Associates, $135 \mathrm{pp}$.

Laboratório Nacional de Engenharia Civil - LNEC. (1969) Engineering properties of lateritic soils. VII International Conference on Soil Mechanics and Foundation Engineering, Mexico, $122 \mathrm{pp}$.

Maignein, R. (1966). Review of research laterites. Natural Resource, UNESCO, Paris, 142 pp.

Moh, Z.C. \& Mazhar, M.F. (1972). Effects of method of preparation on index properties of lateritic soils. Pro- ceeding of the Specialyty Session, Engineering Properties of Lateritic soils, $123 \mathrm{pp}$.

Ferreira, H.N. \& Meireles, J.M.F., Influência nas Propriedades Geotécnicas de Solos Lateriticos, do Umedecimento e da Temperatura. Laboratório de Engenharia de Angola, p. 251-259.

Sharp, K.G., Vuong, B.T., Rollings, R.S., Baran, E., Foley, G.D., Johnson-Clark, J.R. \& Metcalf, J.B. (2009) An Evaluation of the Field and Laboratory Properties of Lateritic Gravels.

Schellmann, W. An Introduction in Laterite, available at http://www.laterite.de/index.html.

Terzaghi, K. \& Robertson, R.H.S (1958).The design and perfomance of the sasumua dam. ICE Proceedings, v. 9:4, p. 369-394.

Villibor, D.F. \& Nogami, J.S. (2009) Pavimentos Econômicos: Tecnologia do Uso dos Solos Finos Lateriticos. Arte \& Ciência, São Paulo, 218 pp. 



\title{
Dewatering Sludge in Geotextile Closed Systems: Brazilian Experiences
}

\author{
M.G.A. Guimarães, D.C. Urashima
}

\begin{abstract}
The use of geotextile closed systems for the dewatering of sludge is a new technology that has been used in recent years in Brazil and globally. This technology has relevant technical and environmental advantages. The variables that influence the operation and evaluation of the efficacy are under constant investigation by the scientific community. This paper presents a state-of-the-art analysis of the use of geotextile closed systems for the dewatering of sludge with high water content, contributing to a better understanding of the fundamentals involved in the technical and scientific application of this technology. This paper also presents the Brazilian experiences with the dewatering of sludge generated in different sectors. This subject has significant relevance; it is a new method to reduce the volume of sludge produced on a large scale and enable final disposal with low environmental impacts.
\end{abstract}

Keywords: : dewatering, geotextile closed systems, sludges.

\section{Introduction}

In Brazil and globally, a current major problem is the increasing production of residuals with high pollution potential, such as byproducts from processes for obtaining goods, materials and services. Therefore, studies on proper residual disposal and handling are of great importance.

The sludge dewatering technique for high liquid content waste using a geotextile closed system has recently proven to be an efficient and viable solution for the reduction of liquid content and consequent reduction in final volume for disposal from a technical, economic and environmental perspective. This technique enables the retention and containment of solid mass, provides one response to questions about the disposal of waste generated by human activities in different segments, and even allows the re-use of dewatering waste in different industries (Fowler et al., 2002; Moo-Young et al., 2002; Moo-Young \& Tucker, 2002; Muthukumaran \& Ilamparuthi, 2006; Lawson, 2008; Satyamurthy \& Bhatia, 2009a).

Since the 1960s, tubes constructed of geotextiles have been used as a containment technology in geotechnical works. In Brazil, in the 1980s, geotextile containment booms were executed within the city of Cubatão-SP (Bogossian et al., 1982).

To better understand the phenomenon of sludge dewatering in geotextiles, several laboratory and field studies have been performed in recent years (Moo-Young et al., 2002; Moo-Young \& Tucker, 2002; Koerner \& Koerner, 2006; Muthukumaram \& Ilamparuthi, 2006; Lawson, 2008; Liao \& Bathia, 2008; Satyamurthy \& Bathia, 2009a; Cantré \& Saathoff, 2011). Models have also been developed. For example, the model proposed by Leshchinsky \&
Leshchinsky (2002) assessed the mechanical stresses in the filling of a geotextile closed system and the Urashima (2002) assessed the simulation of filtration in suspension model.

Recent studies have demonstrated numerous advantages in the use of geotextile closed systems for dewatering sludge. These systems have proven effective for treating sludge generated from Water Treatment Plants (WTP), domestic sewage, industrial processes and the processing of ore (mining), among others.

This paper presents a state-of-the-art technology solution for the dewatering of sludge in geotextiles closed systems, contributing to a better understanding of the technical-scientific methodologies used recently and demonstrating the importance and relevance to the environmental segment. This paper also presents examples of laboratory studies and field applications performed in Brazil.

\section{Dewatering in Geotextile Closed Systems}

\subsection{Initial considerations}

A geosynthetic is "a product at least one of whose components is made from a synthetic or natural polymer, in the form of a sheet, a strip or a three-dimensional structure, used in contact with soil and/or other materials in geotechnical and civil engineering applications" (NBR ISO 10318, 2013).

The first applications of geosynthetics date back to the 1950s, with fabrics manufactured for use as a separation and filter layer between granular soil and soil of low resistance and for critical filtration applications in coastal pro-

M.G.A. Guimarães, PhD. Student, Departamento de Engenharia de Infraestrutura Aeronáutica, Instituto Tecnológico de Aeronáutica, São José dos Campos, SP, Brazil. e-mail: maggeisielly@yahoo.com.br.

C. Urashima, Associate Professor, Departamento de Engenharia Civil, Centro Federal de Educação Tecnológica de Minas Gerais, Belo Horizonte, MG, Brazil. e-mail: urashima@civil.cefetmg.br.

Submitted on January 21, 2013; Final Acceptance on August 2, 2013; Discussion open until April 30, 2014. 
jects in the Netherlands and the United States (Shukla \& Yin, 2006).

The geosynthetics commonly studied for the dewatering of fine waste are the woven and nonwoven geotextiles and the geocomposites formed by woven and nonwoven geotextiles. These materials must demonstrate good filtration performance, which corresponds to the retention capacity of the solid, while allowing the free passage of fluid.

The introduction of geotextile closed systems for the dewatering of sludge was recorded in the 1990s with sewage sludge (a cohesive material with high moisture content and high resistance to filtration), providing the first analysis of dewatering sludge (Fowler et al., 1996; Lawson, 2008). Figure 1 illustrates the application of a geotextile closed system in the dewatering of sludge, commonly referred to as geotextile bags or geotextile tubes, depending on geometrical shape and volume.

The dewatering of sludge in geotextiles is expanding, with increasing use in new applications (Lawson, 2008). The granular soil filters are being replaced by geotextile filters in many environmental projects, which is the oldest application of geosynthetics in civil engineering projects (Christopher et al., 1993).

One of the advantages of using geotextiles for dewatering sludge is that they can be customized for specific project dimensions, depending, for example, on the space available for installation. They can also be stacked on one another (Koerner \& Koerner, 2006; Lawson, 2008). Furthermore, geotextiles provide for the rapid disposal of large volumes of sludge, ease of construction and installation, high efficiency, low costs, minimal environmental impacts (Fowler et al., 2002; Lawson, 2008) and reduced dependence on weather conditions for the realization of dewatering (Mendes et al., 2001).

In the design of dewatering systems with geotextiles, it is essential to match the functional properties of the geotextile with the properties required in the project (Vidal

(a)

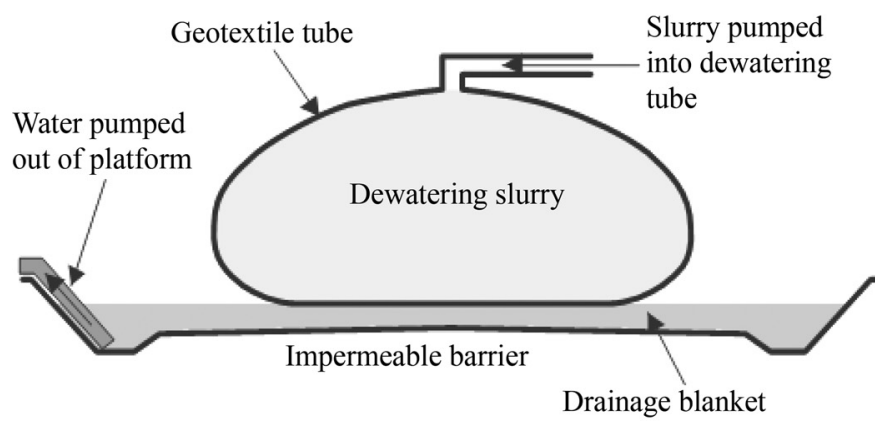

Figure 1 - Geotextile tube dewatering: (a) Details of dewatering; (b) Geotextile tubes used to dewater slurry waste volumes (Lawson, 2008). et al., 1999). The properties of the geotextile must be adapted to the functions and mechanical stresses that they will be subjected (Trentini et al., 2006). The mechanical resistance of the geotextile can be affected by seam performance, potential damage during installation and operation, an accidental increase in pressure pumping of the sludge on the tube, and degradation of the polymer chain by physical, chemical and/or biological agents, among others.

One of the consequences arising from the non-compatibility of seams is the disruption of the geotextile tube by sewing, resulting in leakage of sludge (Leshchinsky \& Leshchinsky, 2002), as illustrated in Fig. 2. Studies must be

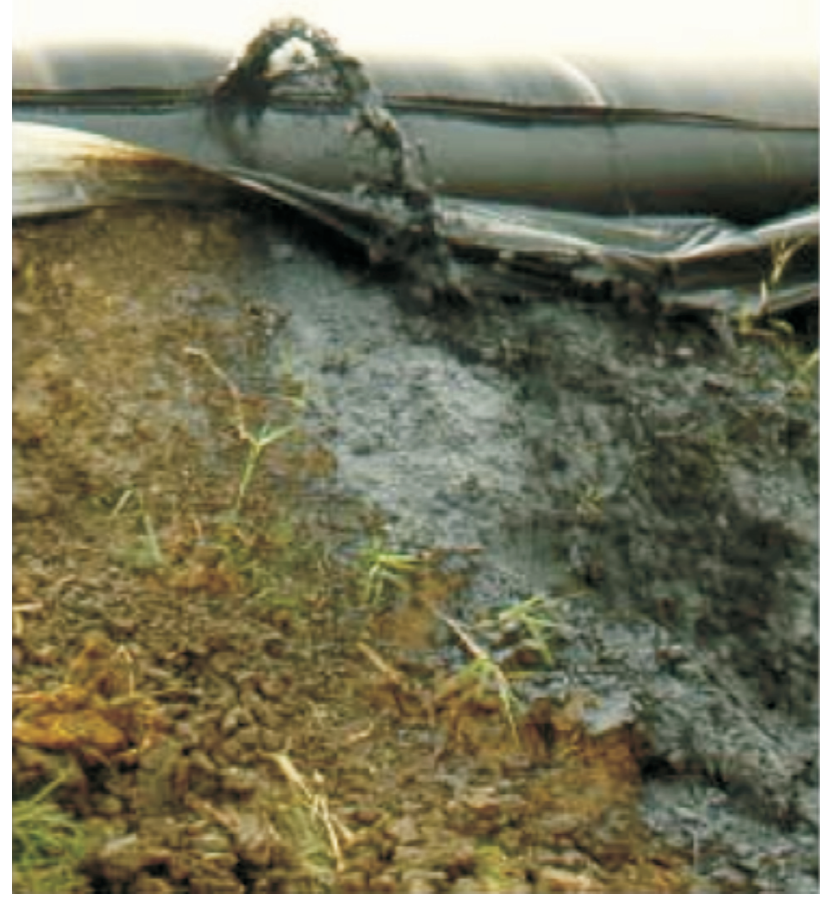

Figure 2 - Failure of a seam on a geotextile tube (Leshchinsky \& Leshchinsky, 2002).

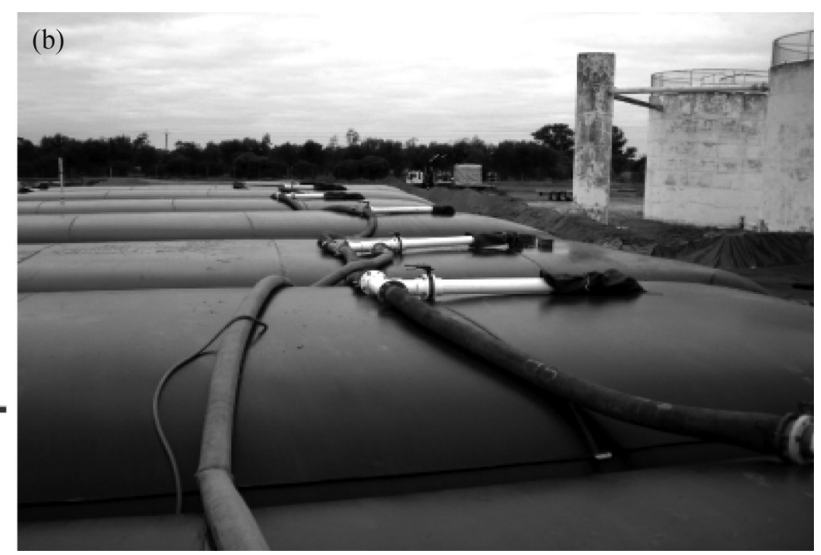


conducted on the efficiency of the seams to verify compatibility with the project requirements and on the factors that may affect the seam resistance, line type and number points, type of sewing and equipment used for its preparation (Ten Cate, 2010).

During dewatering, it is possible to consider two basic types of filtration mechanisms within the geotextile: initially the filtration of suspension particles and then, depending on the type of sludge to be dewatered, the filtration situation under porous conditions.

The filtration of suspension particles is a critical problem because of the hydraulic load loss that occurs when the particle finds the filter and tends to be deposited on surface of the geotextile. This occurs even for particles much smaller than the opening size of the filter element.

The behavior of a filtration system with suspension particles may vary according to the type of material. In the case of granular soil, the retained particles form a trapped material layer that remains permeable in a phenomenon equivalent to the increased thickness of the filter. In the case of cohesive soil, the problem of clogging becomes important. Usually, the clogging is caused by the deposition of a layer of low permeability soil upstream of the filter, as in the dewatering of sludge composed of fine particles (Urashima, 2002).

Depending on the size distribution of the sludge, there may be a tendency to form a pre-filter called a filter cake (Vidal \& Urashima, 1999; Pilarczyk, 2000; Koerner \& Koerner, 2006; Liao \& Bhatia, 2008), which is a mass adhered to the internal structure of the geotextile. This greater concentration of solids relative to the initial state of the sludge in dewatering can function as a low permeability hydraulic barrier.

During filtration under porous conditions, smaller particles of the soil adjacent to the filter may be transported through the geotextile, resulting in a soil structure rearrangement. This can function as a natural filter (pre-filter) according to the size distribution of the base material; the retention of larger particles contributes to the blocking of smaller particles reaching the geotextile (Urashima, 2002).

The filtration of suspension particles has been reported to be more critical to filtration in relation to porous conditions because they tend to deposit on the surface of the geotextile, creating a layer of low permeability (Urashima, 2002). This behavior may cause, in many cases, physical clogging, which can obstruct the passage of fluid through the geotextile, compromising the dewatering of the sludge (Leshchinsky et al., 1996; Vidal \& Urashima, 1999).

Koerner (2005) presents different design methods that ensure the retention of different particle size materials relative to the geotextile filtering openings, considering also a porous-low permeability condition.

Because of the complexity of the composition of the material being dewatered, which often contains very fine particles or organic components, the following condition requirements may influence the behavior of the dewatering systems:

- System compression and traction requirements;

- Intensity and velocity of flow inserted;

- Ambient condition requirements, including fluid characteristics, risks of system degradation, chemical alterations to be dewatered in the middle of the process, and possible physical, chemical or biological clogging.

\subsection{Factors influencing the process of dewatering}

There is a consensus in related literature on the importance of chemical conditioning. It is a 'key point' in the dewatering operations on sludge that presents a high resistance to filtration. The chemical conditioning can be performed with cationic, anionic or non-ionic polymers, depending on the physicochemical characteristics of the sludge. The chemical conditioning causes the solid-liquid separation of the sludge through the coagulation of the solids and the liberation of the adsorbed water, controlling the interaction between suspension, speed and degree of dewatering of the solid mass (Lawson, 2008; Castro et al., 2009; Guanaes, 2009; Satyamurthy \& Bhatia, 2009b). Therefore, an evaluation is necessary to select the most effective conditioning chemical for each type of sludge.

Visual observations of the characteristics of the floc formed (stability) and of the solid-liquid separation are a means to evaluate the polymer and its optimal dosage. However, an inadequate observation of the behavior of the sludge conditioning can result in an inaccurate determination of dosage as well as the indiscriminate use of flocculant polymers (Satyamurthy \& Bhatia, 2009b). It may even lead to changes in the chemical composition of the sludges (Tominaga, 2010).

Pressure and velocity are important in pumping the sludge to dewatering; high force values may result in the breaking of chemical conditioning, which compromises its functionality (Guanaes, 2009).

A parameter that greatly influences the dewatering process is the initial percent of solids in the sludge. At the beginning of filtration, there is a considerable removal of water retained in the solid mass as well as a small passage of suspended particles; the "filter cake" is formed after a period of dewatering. As the filter cake grows during filtration, the filtrate volume is reduced with the decrease in turbidity (Moo-Young et al., 2002; Moo-Young \& Tucker, 2002; Muthukumaran \& Ilamparuthi, 2006; Lawson, 2008).

The sludge dewatering causes a concentration of the solid mass within the geotextile closed systems and a decrease in volume, with a concentration of physical, chemical and biological parameters, when compared with the initial sludge values (Guanaes, 2009).

For materials that have a high liquid content and a low permeability, Umezaki et al. (2007, apud Tominaga, 2010) proposed the vacuum dewatering of high liquid content ma- 
terials in a geotextile closed system, based on the initial conception of Umezaki and Kawamura (2002, apud Tominaga, 2010). This dewatering method involves applying a vacuum pressure in the geotextile closed system, creating a suction effect that accelerates the dewatering.

Umezaki et al. (2007, apud Tominaga, 2010) then performed laboratory tests to compare the conventional dewatering method with vacuum dewatering. The geotextile closed system consisted of a double-layer bag and internal plate drainage. The authors noted a further reduction in the height of the geotextile closed system and achieved lower water contents in shorter periods of dewatering compared to the conventional method.

\subsection{Parameters for performance analysis}

The performance of dewatering systems can be evaluated through the following parameters: filtration efficiency (FE), dewatering efficiency (DE), infiltration efficiency (IE), piping (PP) and solids passing (SP).

The filtration efficiency is the relation between the total solids in the sludge before dewatering and the total solids in the filtrate after filtration (Moo-Young \& Tucker, 2002) and expressed as:

$$
\mathrm{FE}=\frac{\mathrm{TS}_{\text {initial }}-\mathrm{TS}_{\text {final }}}{\mathrm{TS}_{\text {initial }}} \times 100 \%
$$

where FE is the filtration efficiency $(\%), \mathrm{TS}_{\text {initial }}$ is the initial total solids in the sludge (mg.L $\left.\mathrm{L}^{-1}\right)$, and $\mathrm{TS}_{\text {final }}$ is the final total solids in the filtrate $\left(\mathrm{mg} . \mathrm{L}^{-1}\right)$.

Satyamurthy \& Bathia (2009b) stated that successful dewatering in geotextiles requires maximizing filtration efficiency and minimizing dewatering time (the time required to dehydrate a known volume of sludge).

The dewatering efficiency is defined as the change in the solids percentage before and after dewatering (MooYoung et al., 2002), given by:

$$
\mathrm{DE}=\frac{\mathrm{PS}_{\text {final }}-\mathrm{PS}_{\text {initial }}}{\mathrm{PS}_{\text {initial }}} \times 100 \%
$$

where DE is the dewatering efficiency $(\%), \mathrm{PS}_{\text {initial }}$ is the initial percent solids (\%), and $\mathrm{PS}_{\text {final }}$ is the final percent of solids $(\%)$.

The infiltration efficiency is defined as the relation between the water content of the sludge before and after dewatering (Muthukumaran \& Ilamparuthi, 2006), as described:

$$
\mathrm{IE}=\frac{\mathrm{W}_{\mathrm{i}}-\mathrm{W}_{\mathrm{f}}}{\mathrm{W}_{\mathrm{i}}} \times 100 \%
$$

where IE is infiltration efficiency $(\%), \mathrm{W}_{\mathrm{i}}$ is the initial water content of the sludge $(\%)$, and $\mathrm{W}_{\mathrm{f}}$ is the final water content of the sludge $(\%)$.

Urashima et al. (2010) demonstrated that the term infiltration efficiency is not the most appropriate for a dewatering process that uses a geotextile closed system. However, this equation is representative of the dewatering process.

The piping is a parameter that reflects the retention capability of a geotextile by weight of suspended solids passing through the geotextile during dewatering (Satyamurthy \& Bhatia, 2009a) and it is expressed as:

$$
\mathrm{PP}=\frac{\mathrm{TSS}_{\text {final }}}{\mathrm{A}}
$$

where PP is piping $\left(\mathrm{g} \cdot \mathrm{m}^{-2}\right), \mathrm{TSS}_{\text {final }}$ is the final total suspended solids $(\mathrm{g})$, and $\mathrm{A}$ is the effective area of the geotextile in dewatering $\left(\mathrm{m}^{2}\right)$.

However, the use of the suspended solids concentration in the evaluation of piping is not accurate because the solids present in the filtrate are, in fact, the total solids, which are the suspended solids plus the dissolved solids. Thus, Tominaga (2010) proposes the substitution of suspended solids with total solids.

The solids passing reflects the dewatering performance by comparing the suspended solids in the filtrate with the initial total solids of the sludge in accordance with the formulation proposed by Satyamurthy (2008, apud Satyamurthy \& Bhatia, 2009a). It is given by:

$$
\mathrm{SP}=\frac{\mathrm{TSS}_{\text {final }}}{\mathrm{TS}_{\text {initial }}} \times 100 \%
$$

where SP is the solids passing $(\%), \mathrm{TSS}_{\text {final }}$ is the total suspended solids in the filtrate $\left(\mathrm{mg} \cdot \mathrm{L}^{-1}\right)$ and $\mathrm{TS}_{\text {initial }}$ is the total initial solids of the sludge $\left(\mathrm{mg} \cdot \mathrm{L}^{-1}\right)$.

Among the parameters used in the quantification of a geotextile for dewatering, the solids passing is a simple and accurate measure of the dewatering system performance (Satyamurthy \& Bhatia, 2009a). Finally, Tominaga (2010) reported that the suspended solids in the solids passing (SP) formula should be replaced by the total solids in the filtrate, as also used in the piping (PP).

\section{Proposed of Standardization for Dewatering Tests}

\subsection{Cone tests}

The cone test is a methodology described by Lawson (2008) that evaluates the need to use a chemical conditioning agent to assist in the dewatering of sludges in geotextiles (Castro, 2005; Martins, 2006; Castro et al., 2009; Guanaes, 2009). This test also allows for the evaluation of the best dosage and concentration of polymeric additives to be added to the sludge under study, without the provision of behavior parameters.

As described previously, the use of a polymeric additive for solid-liquid separation has a great influence on the dewatering of fine sludges that have a high water content relative to solids, allowing the removal of adsorbed water in the solids. As a result, they enable a significant reduction in 
the volume of sludge for disposal or recycling and, in some cases, the recirculation of water to treatment or for re-use in the system.

It is important to determine the cost of each polymeric additive and the impact of increasing the dosage because there may be a high daily consumption of a polymeric additive depending on the volume and type of sludge.

As an example, the results of a cone test are presented to evaluate 6 (six) different polymeric additives for the solid-liquid separation of sludge used in the water purifiers of City Eloi Mendes (Minas Gerais, Brazil). The sludge used is shown in Fig. 3.

The polymeric additives were evaluated at a concentration of $0.004 \mathrm{~g} . \mathrm{L}^{-1}$. The dosages tested were $10 \mathrm{~mL}$ and $15 \mathrm{~mL}$ per $500 \mathrm{~mL}$ of sludge. The parameters evaluated in each cone test were the filtrate turbidity (NTU), the final water content of the sludge dewatering (Fig. 4a) and the final volume of filtrate (Fig. 4b) 10 minutes after the beginning of the test. Figure 5 shows the results obtained for the $10 \mathrm{~mL}$ dosage of polymeric additive. Figure 6 displays the results for the $15 \mathrm{~mL}$ dosage.

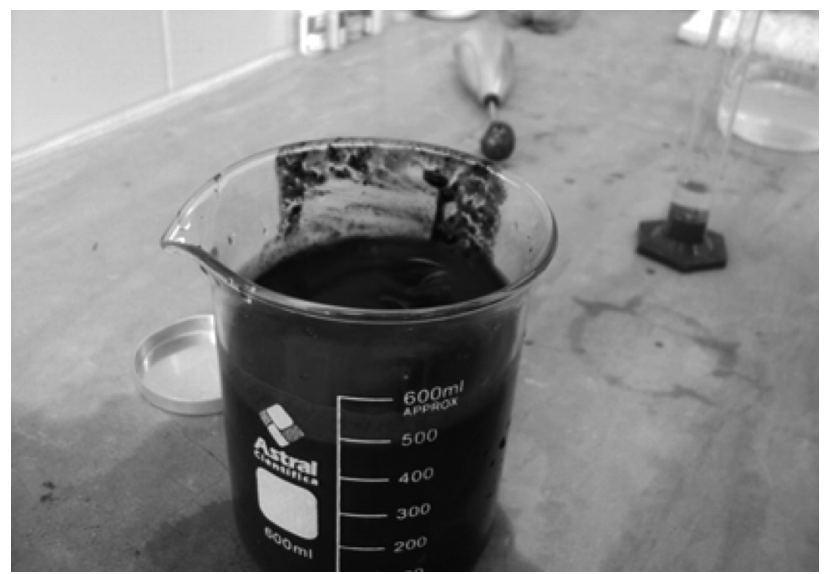

Figure 3 - Sludge utilized in cone tests.

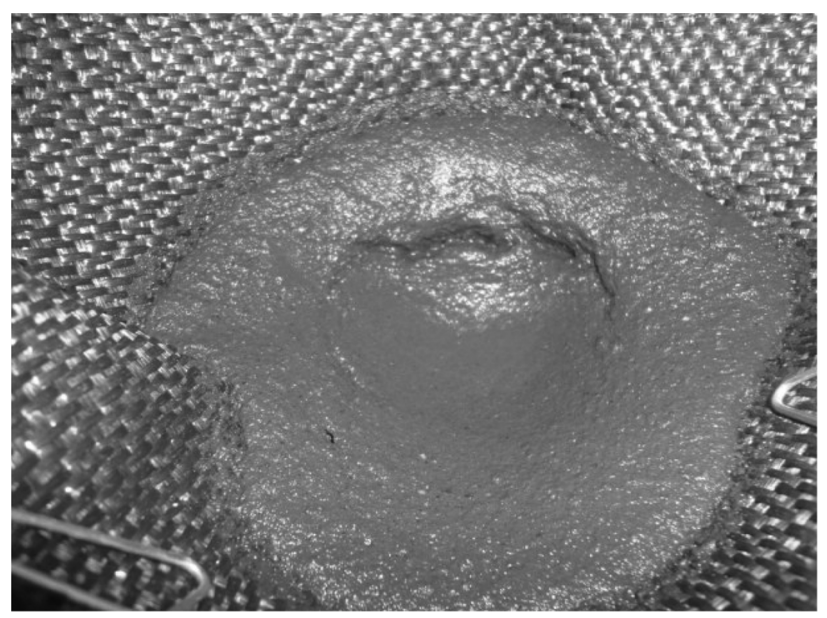

(a)
It is possible to verify that the turbidity (NTU), the volume of filtrate collected $(\mathrm{mL})$ and the final water content $(\%)$ differ for each type of chemical conditioning and even between the dosages used $(10 \mathrm{~mL}$ and $15 \mathrm{~mL})$. In general, low values of turbidity indicate a lower passage of small particles through the geotextile concomitantly with the passage of liquid present in the sludge. In addition, lower liquid contents indicate a greater removal of sludge liquid, which indicates better dewatering.

For the $10 \mathrm{~mL}$ dosage (Fig. 5), better results were obtained for the Polymer 934 because of the lower value of turbidity (NTU) and the good reduction of liquid present in the sludge. Additionally, $213.5 \mathrm{~mL}$ of filtrate was obtained, greater than the average amount of filtrate obtained among the other polymers tested $(204.0 \mathrm{~mL})$.

For the $15 \mathrm{~mL}$ dosage (Fig. 6), the Polymer 934 also excelled in terms of turbidity and volume of filtrate obtained. However, there was an increase in the final water content of the sludge (916.2\%). Even after increasing the polymer dosage to $15 \mathrm{~mL}$, there was no improvement in the

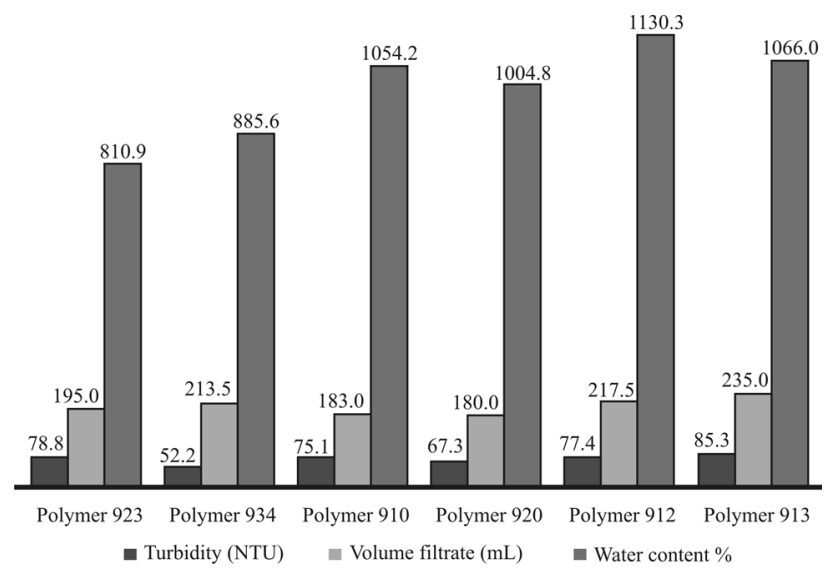

Figure 5 - Cone tests with $10 \mathrm{~mL}$ polymer dosage at a concentration of 0.004 g. $\mathrm{L}^{-1}$.

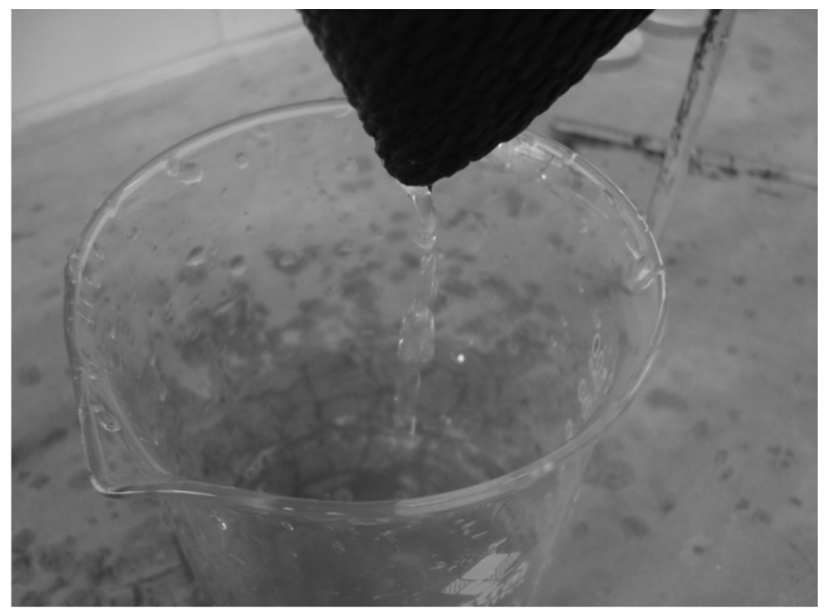

(b)

Figure 4 - Cone tests: (a) Sludge dewatering; (b) Filtrate obtained. 


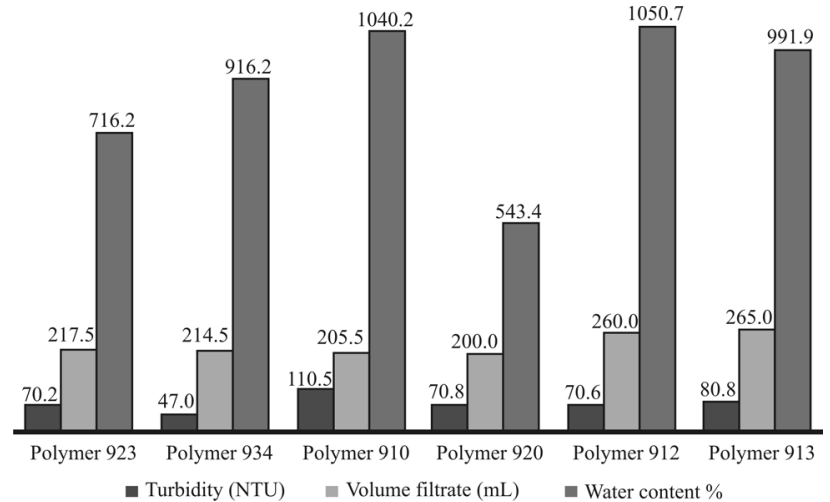

Figure 6 - Cone tests with $15 \mathrm{~mL}$ polymer dosage at a concentration of 0.004 g.L. $\mathrm{L}^{-1}$.

measured parameters (reduction of turbidity and water content, increase of volume of filtrate) for all of the tested polymers. Therefore, increasing the dosage does not necessarily result in better chemical conditioning, which emphasizes the importance of obtaining an optimum dosage, as also discussed in studies by Tominaga (2010).

\subsection{Dewatering tests in geotextile bags}

The ASTM International published a standard method to determine the flow rate of water and suspended solids in a geosynthetic permeable bag containing high water content sludges (ASTM D 7701, 2011). This methodology describes two test methods. One test involves using a geotextile bag with a $114 \mathrm{~cm}$ inner circumference, a length of $165 \mathrm{~cm}$ and a volumetric test capacity of 150 to $190 \mathrm{~L}$. The other test uses a geotextile bag with a $1.52 \mathrm{~m}$ circumference, a depth of $0.92 \mathrm{~m}$, with a volumetric test capacity of $19 \mathrm{~L}$.

The Geosynthetic Research Institute (GRI) has also proposed methodologies to analyze the behaviors of materials in dewatering, such as GRI-GT14 (2004) and GRIGT15 (2009). The first method is for field dewatering of solids in a hanging bag test (HBT), as shown in Fig. 7, with one of the faces open and a linear length between 0.3 and $7.0 \mathrm{~m}$.

The GRI-GT15 (2009) serves an identical purpose as the GRI-GT14 (2004); however, it uses geotextile bags with approximate dimensions of 50 to $65 \mathrm{~cm}$ in length, 38 to $65 \mathrm{~cm}$ in width and a volumetric capacity of 20 to $30 \mathrm{~L}$. These bags contain an adapter flange to guide the sludge with polymeric additives into the bags (Fig. 8). Another difference between the methods is that the GRI-GT15 (2009) allows for the monitoring of the dewatering performance over time by observing the dehydrated material column $(\mathrm{cm})$ by test time (min).

Castro et al. (2009) conducted a comparative study of both methods described above. This study showed that the GRI-GT15 (2009) method produces results very close the actual application of dewatering in geotextile bags; the

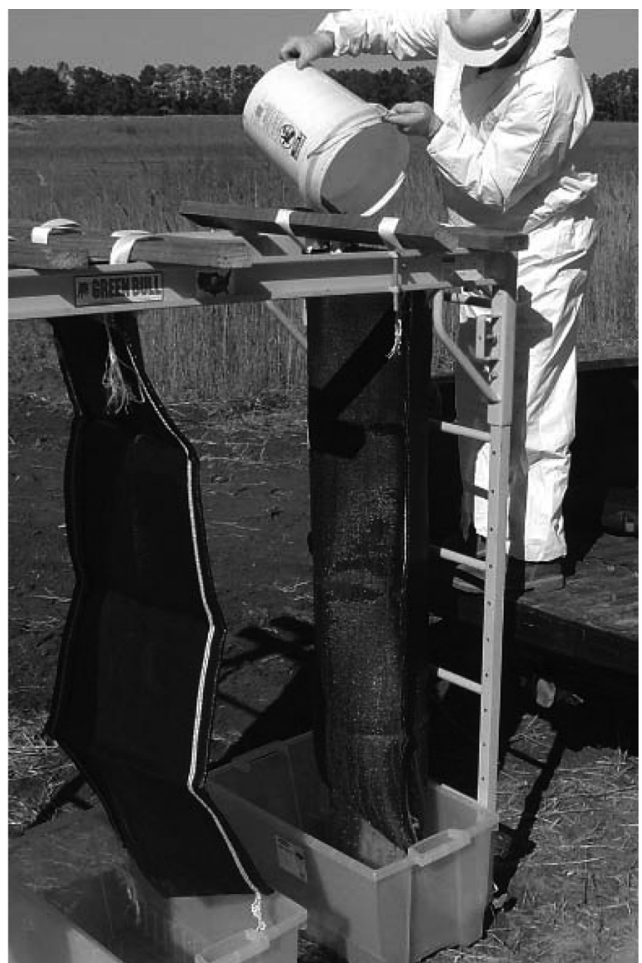

Figure 7 - Hanging bag test (Lawson, 2008).

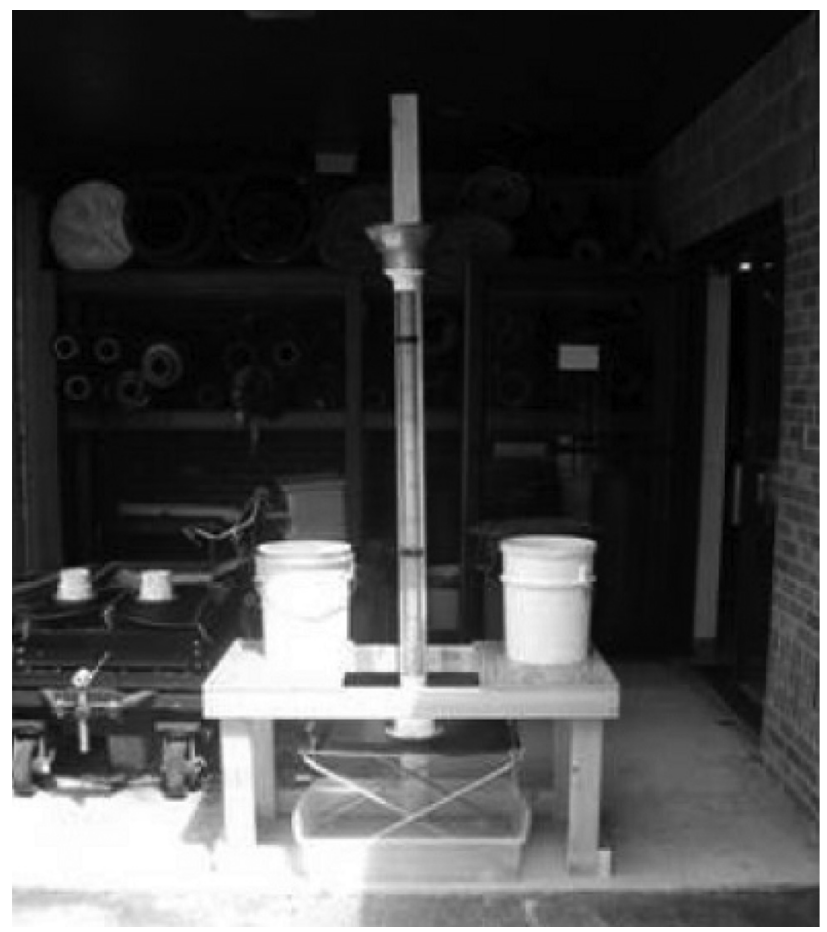

Figure 8 - Tests in geotextile closed according to GRI-GT15 (Geosynthetic Research Institute, 2009).

sludge remains confined within the geotextile bags, which allows for better dewatering and prevents rehydration of the dry sludge. There is also a low breakdown of chemical conditioning with the introduction of sludge within the geotex- 
tile bags compared to the methodology proposed by GT14GRI (2004) because it occurs at less critical conditions.

Tominaga (2010) conducted laboratory studies to evaluate the performance of geotextile closed systems for sludge dewatering, which included cone tests for the evaluation of chemical conditioning and tests of small dimensions as proposed by GRI-GT15 (2009). In their studies, Tominaga (2010) used three materials with high water contents (kaolinite, powder-rock and sludge from WTP) for dewatering.

Tominaga (2010) demonstrated some inaccuracies in the methodology proposed by GT15-GRI (2009), such as the reading of the descent level of the sludge in the transparent tube installed above the geotextile bag. There is no specification of important readings to measure the quality of filtrate and of sludge dewatering and also the dewatering performance. Thus, Tominaga (2010) suggested some changes in the methodology proposed by the GRI-GT15 (2009) to provide a better assessment of dewatering using geotextile closed systems, such as fixing a reservoir at the top of the standpipe with a valve to control the filling of the bags; suspending the standpipe from a tripod and brace; and replacing the nozzle in the flange of the geotextile bag with the nozzle in the sleeve formed by the geotextile in the lateral position of the bag.

\section{Brazilian Laboratory Study and Field Applications Experiences}

\subsection{Sludge dewatering at water treatment plants (WTPs)}

The residues generated in WTPs, called wash water and sludge decanter, are produced in large quantities that may equal $5 \%$ of the volume of water treated in the process (Fontana \& Cordeiro, 2005). These residues consist of fluids with high water contents, generally greater than $95 \%$ (Reali et al., 1999), and solid sludge.

Thus, the reduction in its volume minimizes the risk of contamination of water and environmental resources. This also reduces the volume of residues to be properly disposed of, with a reduction in transport and disposal costs (Fontana \& Cordeiro, 2005).

The legal aspects of environmental protection in Brazil have prompted studies of the treatment and final disposal of WTP residues (Fontana \& Cordeiro, 2005). The inadequate disposal of these residues in the environment leads to damaging impacts, such as siltation of watercourses, soil contamination (Reali et al., 1999; Andreoli et al., 2001) and water source contamination (Hoppen et al., 2003), and can aggravate water shortages for supply and purifiers (Mendes et al., 2001).

Urashima et al. (2010) conducted studies of WTP sludge dewatering using geotextile bags with dimensions $60 \mathrm{~cm} \times 50 \mathrm{~cm}$ and constructed of three types of geotextiles
(GT1, GT2 and GT3) with different filtration openings and tensile strength.

Cone tests were performed to verify the concentration and dosage of the polymer for sludge chemical conditioning.

Finally, a prototype was constructed (Fig. 9) that simulated the conditions of WTP pressure pumping. This prototype contains a reservoir for $75 \mathrm{~L}$ of residue, an inverter frequency to fix the average flow of pumping residue, a pressure transmitter and mixer screens for performing the chemical conditioning.

The dewatering system was assessed based on the filtration efficiency (FE), efficiency dewatering (DE) and infiltration efficiency (IE) parameters and on a verification of the decrease in filtrate turbidity during dewatering. This analysis is important because it is an indirect measure of the presence of solids or other particulate in the filtrate suspension.

Urashima et al. (2010) obtained average values of $98.1 \%$ for FE, $300.9 \%$ DE and $70.3 \%$ of IE for the three geotextiles tested (GT1, GT2 and GT3). This study showed that the geotextile bag has a good solid particle retention capacity, concomitant with free passage of liquid present in the sludge, thus enabling dewatering and reduction of large volumes for correct disposal or use in other industries as discussed in literature (Tsutuya \& Hirata, 2001; Hoppen et al., 2003; Oliveira et al., 2004; Hoppen et al., 2005).

Guimarães et al. (2012) conducted dewatering studies with successive pumping of sludge into the same geotextile bag, called dewatering with refills. The same equipment constructed by Urashima et al. (2010), after some adjustments to the structure, was used, as shown in Fig. 10.

There were three successive dewaterings conducted in the same geotextile closed system with dimensions of $60 \mathrm{~cm} \times 60 \mathrm{~cm}$. The time between the first and second dewatering was $72 \mathrm{~h}$, and the time between the second and third dewatering was 24 hours. The polymeric additive

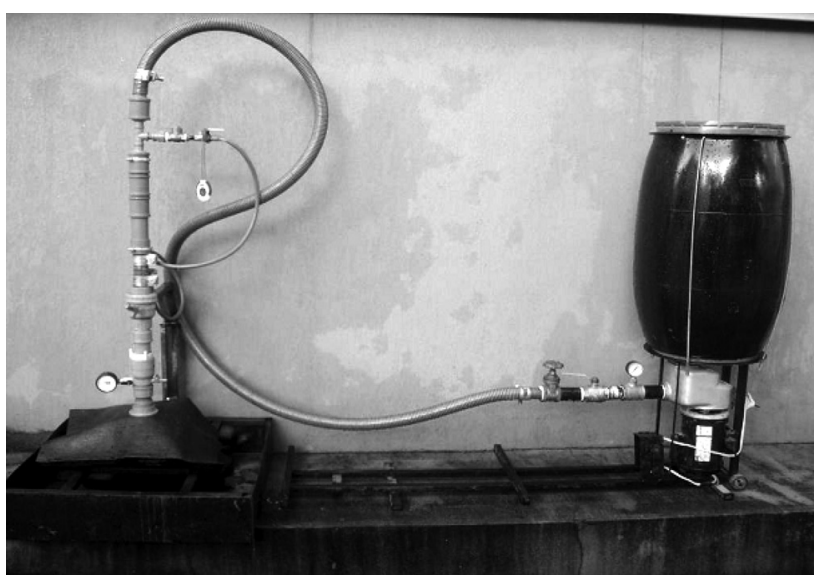

Figure 9 - Equipment for pressurized filling and dewatering (Urashima et al., 2010). 
used was identical to that used by Urashima et al. (2010), but in different concentrations. Each dewatering was performed with $75 \mathrm{~L}$ of sludge at an average sludge pumping flow of $0.75 \mathrm{~L} . \mathrm{s}^{-1}$.

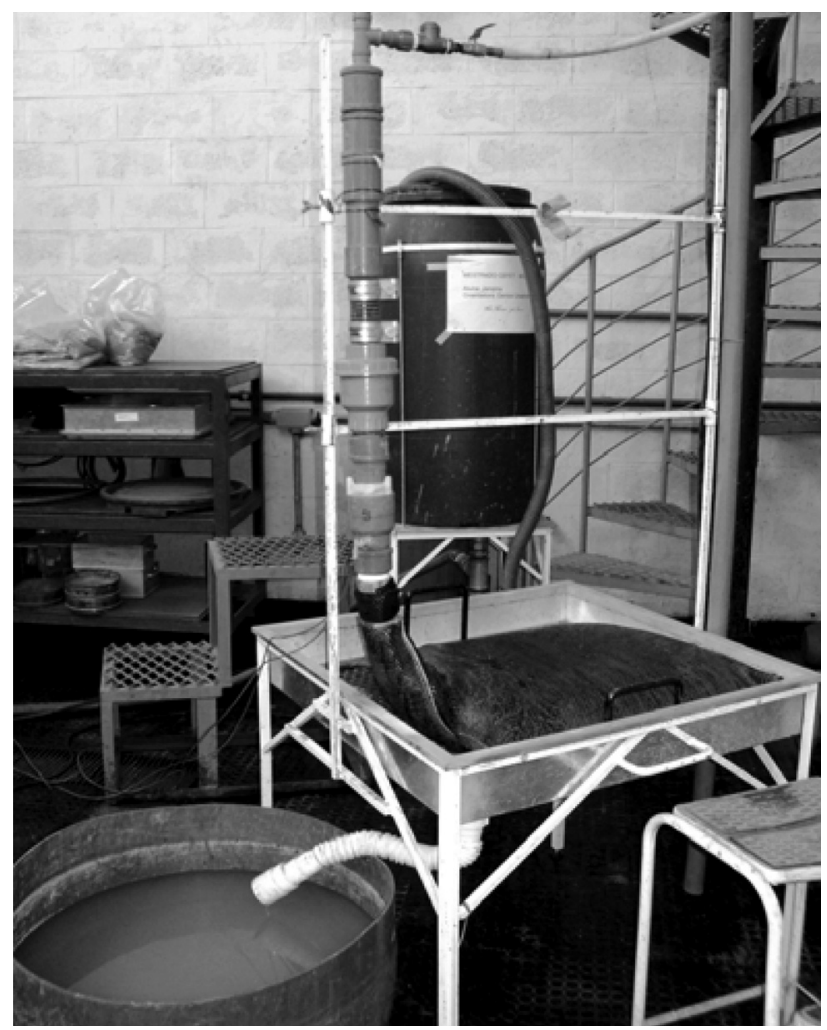

Figure 10 - Prototype for the dewatering of sludge from a WTP in a geotextile bag (Guimarães et al., 2012).

The dewatering system was assessed based on FE, PP and SP. The last two parameters were measured according to Tominaga (2010). The average results obtained were FE $97.2 \%, 2.8 \% \mathrm{SP}$ and PP $0.6 \mathrm{~g} . \mathrm{m}^{-2}$. There was an increase in FE after each dewatering and a decrease in SP and PP. This result indicates an increase in the retention of solid particles after successive recharges of sludge into the same geotextile bag.

\subsection{Sludge dewatering in mining}

Mining sludges are produced in the processing of raw ore (iron, bauxite, kaolin, graphite, gold, phosphate, etc.). They are generated in large volumes, and the granular characteristics depend directly on the beneficiation process used in mining.

Because of the increase in mining activities in Brazil, there has been an increase in sludge generation. This situation has been aggravated by the absence of final disposal sites, technical and environmental storage constraints and the costs associated with transportation to the storage location. This has become one of the greatest chal- lenges of modern geotechnical engineering (Bittar et al., 2010).

The dewatering of mining sludges in geotextile closed systems thus provides a viable solution to the techni$\mathrm{cal}$, economic and environmental concerns cited (Martins, 2006). In addition, the dewatering in geotextiles enables recirculation and recuperation of water inserted into the process, directly impacting the costs associated with beneficiation and producing smaller volumes of sludge for final disposal (Barbosa, 2011).

Gomes (2007) demonstrated some of the principles and potential applications of geotextile tubes for dewatering of mining sludges in pulp, highlighting the operational and economic advantages compared to conventional processes, such as the storage of sludge in dams with the risk of catastrophic rupture.

Martins (2006) used suspended geotextile bags (Fig. 11a) to conduct laboratory and field studies of the dewatering of sludges from the beneficiation of phosphate rock with two different particle sizes: fine-grained (called sludge), $100 \%$ of the particles with diameters of less than $0.074 \mathrm{~mm}$ (Fig. 11b); and granular sludge with sandy characteristics, $34 \%$ of the particles in the silt fraction (Fig. 11c).

Martins (2006) evaluated the effect of filtration efficiency $(\mathrm{FE})$ during the dewatering period, obtaining the final results in approximately $100 \%$ of the fine-grained (sludge) and granular sludge.

Barbosa (2011) conducted studies of dewatering of sludge produced from the beneficiation of phosphate rock with a high content of fine particles with silt characteristics. Geotextile bags were used (Fig. 12), with a size of $60 \mathrm{~cm} \mathrm{x}$ $60 \mathrm{~cm}$ and constructed of three geotextiles with different filtration openings and hydraulic permeability.

Dewatering tests conducted by Barbosa (2011) were performed by pumping the sludge that was chemically conditioned with anionic polymer. A prototype that simulated the conditions of pressure pumping of sludge building was used by Urashima et al. (2010).

Barbosa (2011) obtained average values of $99.1 \%$ for FE, $686 \%$ for DE, $0.9 \%$ for SP and 0.8 g.m 2 for PP for the three geotextile bags.

Bittar et al. (2010) performed studies on the dewatering of phosphate fine sludge from ore treatment processes (90\% of the particle sizes below 325 mesh) using geotextile bags of small dimension second GRI-GT15 (2009) and Castro et al. (2009) and sludge collected directly from the discharge point. The objective of this study was to evaluate the quality of the filtrate collected and to determine the time required to obtain the desired solids content during the dewatering in geotextile bags (Fig. 13).

Bittar et al. (2010) performed preliminary cone tests with different polymeric additives, reaching a concentration of 10 ppm (Fig. 14). 


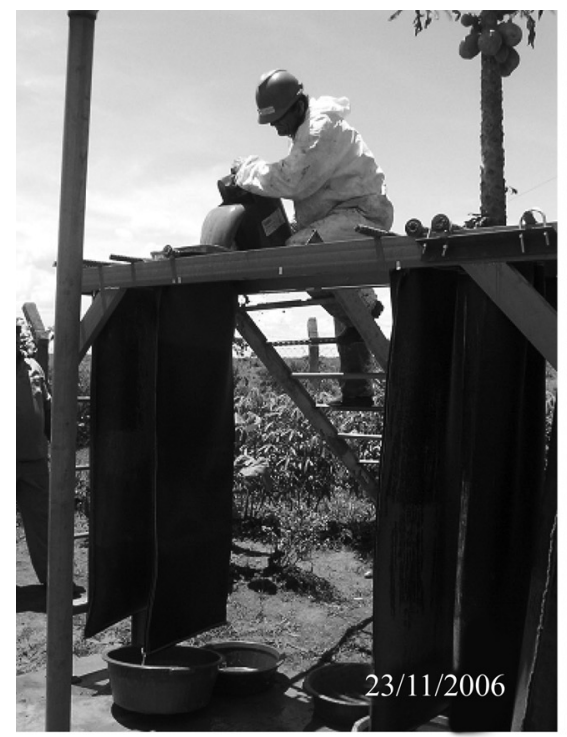

(a)

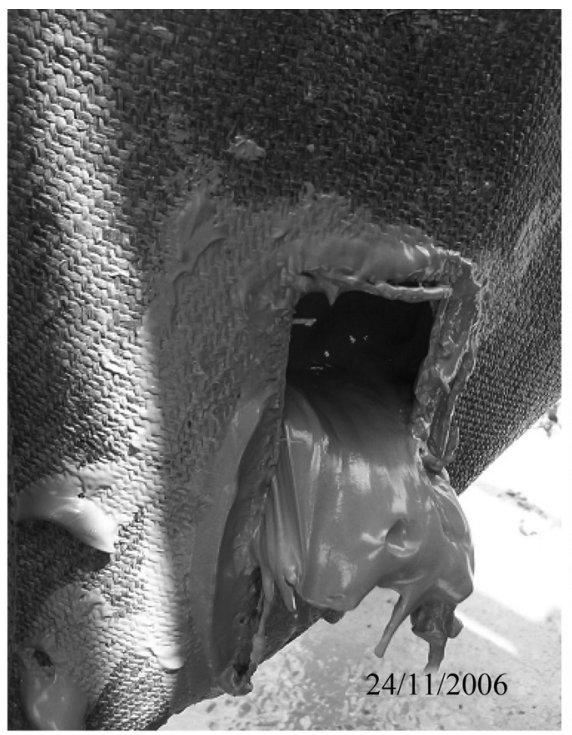

(b)

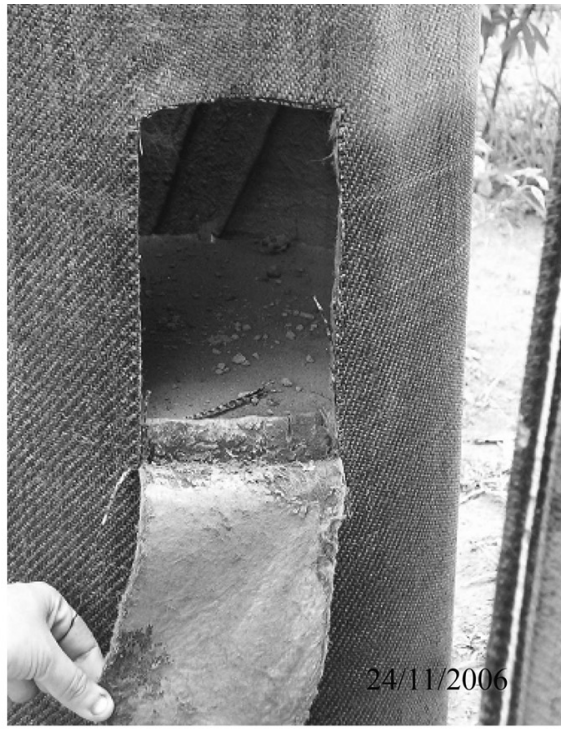

(c)

Figure 11 - Dewatering mining sludges in suspended geotextile bags: (a) Detail of bags used; (b) reject fine-grained (sludge); (c) granular sludge (Martins, 2006).

Bittar et al. (2010) obtained $\mathrm{P}_{2} \mathrm{O}_{5}$ and $\mathrm{MgO}$ concentrations similar to the initial mine deposit values, approximately $5 \%$ and $4 \%$, respectively. A total solids concentration of $74.70 \%$ was reached after 10 days of dewatering, with an initial value of total solids in the sludge of $12.60 \%$. Furthermore, the water content ranged from $87.40 \%$ (initially) to $25.3 \%$ during this period.

\subsection{Sludge dewatering of septic tank sludge}

Castro et al. (2008) performed a field implementation of four geotextile tubes for the dewatering of sewage sludge collected from septic tanks using vacuum trucks and from landfill leachate in the Rio das Ostras City (RJ, Brazil). Two geotextile tubes $30 \mathrm{~m}$ in length and $13.7 \mathrm{~m}$ in circumference and two geotextile tubes $60 \mathrm{~m}$ in length and $13.7 \mathrm{~m}$ in circumference (Fig. 15) were installed.

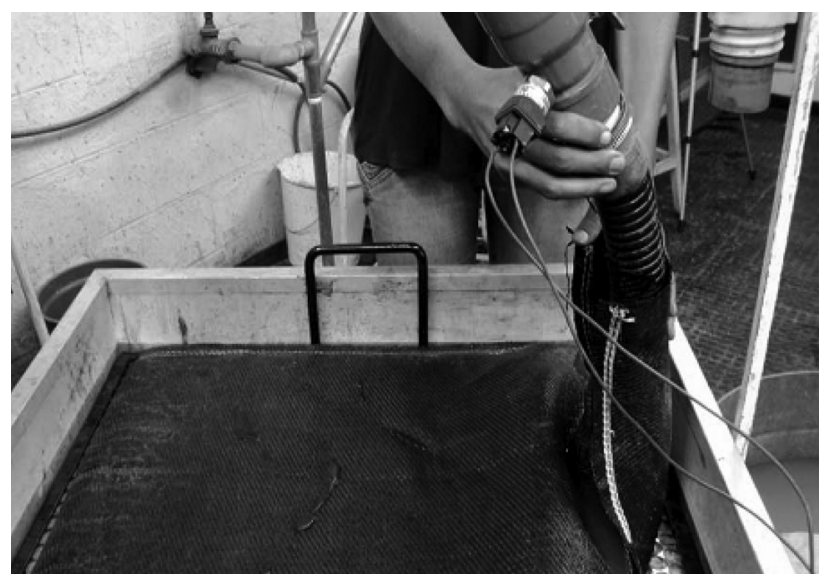

Figure 12 - Geotextile bag for dewatering sludge from beneficiation of phosphate rock (Barbosa, 2011).
The project was developed to reduce and dispose of large volumes of sludge generated in the city, which had no capacity to meet the high demands of sludge generation because of the large annual population increase. The project

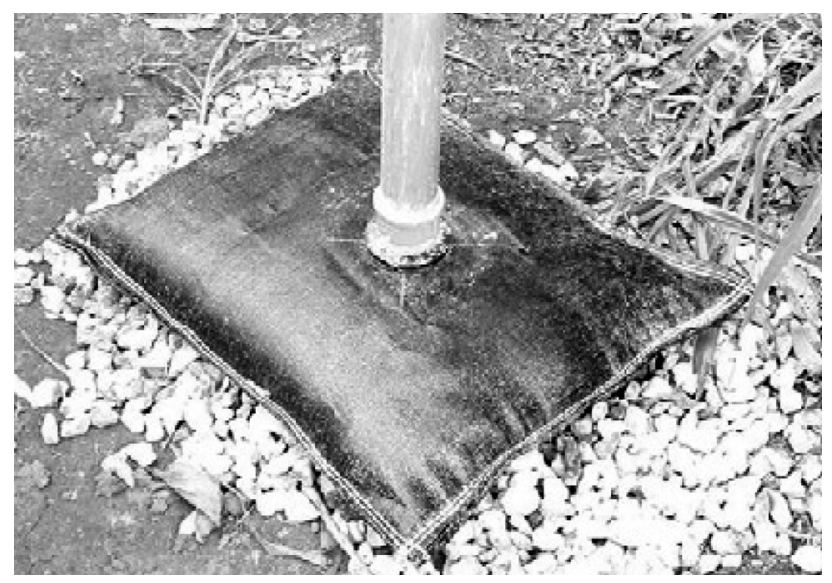

Figure 13 - Small scale geotextile tube (Bittar et al., 2010).

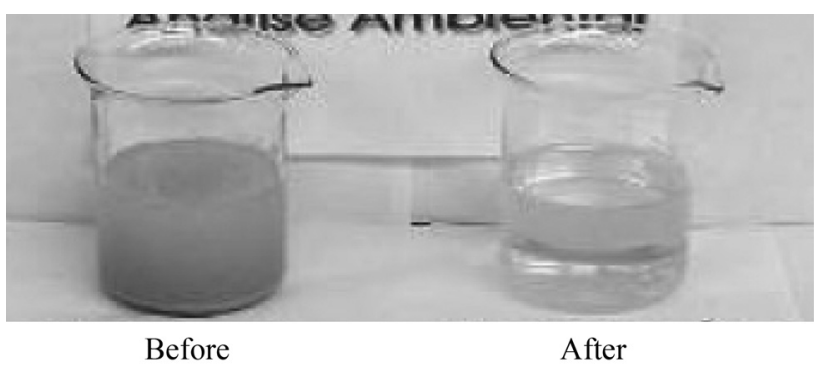

Figure 14 - Phosphate tailings passed, before and after the cone test (Bittar et al., 2010). 


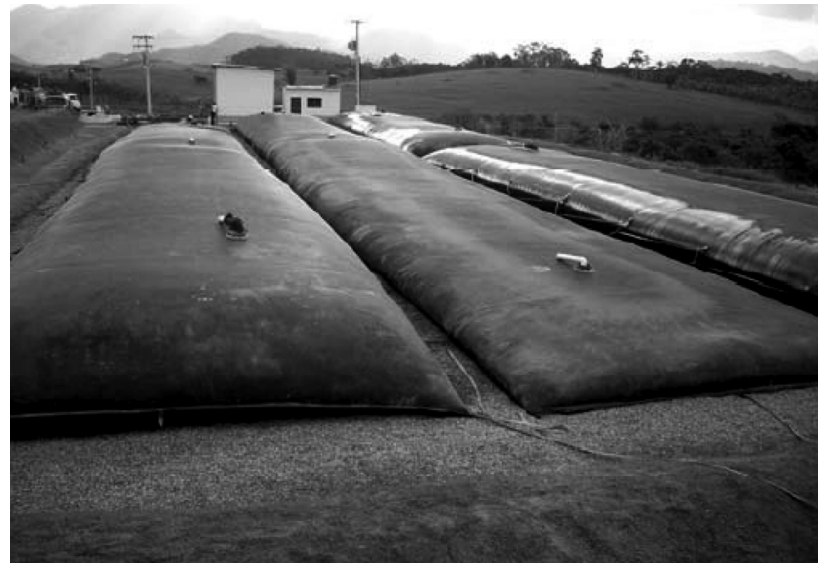

Figure 15 - Geotextile tubes for dewatering effluent in the Rio das Ostras City, RJ, Brazil (Castro et al., 2008).

met the demand of 34.000 cubic meters of sludge containing an average total suspended solids (TSS) of $1 \%$.

The sludge from the septic tanks and landfill leachate were mixed in an equalization tank, and a cationic polymer was added for flocculation. The sludge mixture was then pumped into the geotextile tubes to dehydrate the sludge, retaining the solid portion and removing the liquid (filtrate). Each geotextile tube was constructed with a drainage system to collect the liquid extracted from the sludge.

Castro et al. (2008) obtained satisfactory results, achieving a significant reduction in biochemical oxygen demand (BOD) and chemical oxygen demand (COD) as well as increased total suspended solids (TSS) after sludge dewatering. Furthermore, the filtrate collected was monitored periodically for chemical parameter acceptability for subsequent discharge and/or return to the sludge treatment system. A portion of the filtrate collected from the last geotextile tube was used for gardening in the Rio das Ostras City (RJ), and a portion was used for compacting landfill.

\subsection{Sludge dewatering of industrial effluent}

Escobar et al. (2010) presented a case study using geotextile tubes for the sludge dewatering of industrial effluent with a high moisture content contaminated with hydrocarbons, salts and other chemical compounds.

The sludge for dewatering originated from the cleaning of the cooling towers of the Brazilian Petrochemical Company Braskem - Petrochemical Basics Unit, which generated a total volume of $2200 \mathrm{~m}^{3}$.

The cooling towers were emptied, and a pump was used to remove and clean the sludge from the towers. The total volume of sludge was removed by six vacuum trucks, which transferred the sludge with a high moisture content and chemical contamination to two equalization tanks, with subsequent pumping into two geotextile tubes with a capacity of $400 \mathrm{~m}^{3}$ each. Polymer additives were added for flocculation of the sludges. Figure 16 illustrates the process steps and the location of the geotextile tubes used for sludge dewatering.

Escobar et al. (2010) reported promising results from the project: a $95 \%$ reduction in the volume of dewatering sludges after two months, in addition to the recovery and subsequent use of the entire filtrate drained from the geotextile tubes. Finally, the dewatering sludges were removed for disposal by CETREL, a Brazilian Waste Management and, providing a safe destination, from an environmental perspective, for the wastes generated during the cleaning of cooling towers.

\section{Discussion and Conclusion}

Geotextile closed systems have great application versatility, as exemplified by the Brazilian applications cited

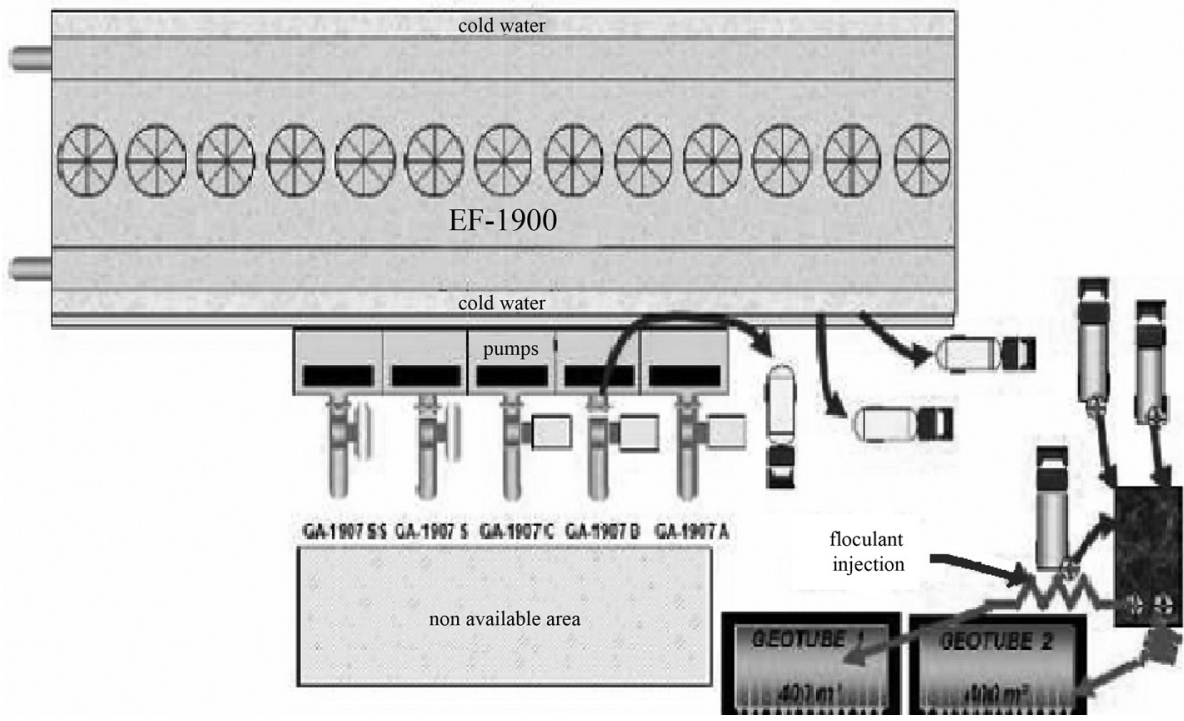

Figure 16 - Dewatering of Braskem Company mining sludges in geotextile tubes (Escobar et al., 2010). 
in this paper, such as the single dewatering system or when used together with other techniques. They have also demonstrated easy adaptability to different installation sites.

The efficiency parameters for the performance analysis of the dewatering systems are important in the evaluation of their behavior. These parameters can be affected by several factors, such as water content relative to solids, formation of filter cake, particle size and composition of sludge, opening size and hydraulic conductivity characteristics of the geotextile, and chemical conditioning requirements, among others.

For the good performance of the system under study, it is necessary to evaluate and observe the following aspects:

- The behavior of the seams in light of the field demands, along with the set of elements responsible for the life time of the geotextile closed system, and the mechanical strength and durability of the geotextiles considering physical, chemical and biological agents;

- The characterization of the materials to be dewatered because the efficiency of the method depends on the type of sludge to be dewatered and the filtering characteristics of the geotextile, which may be considered together or separately;

- The possible occurrence of physical, chemical and biological clogging. The physical clogging is an inherent factor. Tests should be conducted with the sludge and the geotextile to evaluate the clogging evolution and its acceptability.

Currently, there are several methodologies for the performance evaluation of geotextiles as a filter material to estimate possible results at a laboratory-scale. From these results, it is possible to optimize the geotextile closed system by improving the parameters that may improve its functioning.

In particular, the cone tests have been used successfully in several studies to preliminarily evaluate the need for chemical conditioning and dosage determination.

In the last decade, studies and field applications of the dewatering of residues and sludges in geotextile closed systems have been conducted in Brazil. These studies have shown promising results that indicate the feasibility of geotextile use in dewatering systems.

The dewatering of sludges in geotextile closed systems is of significant current technical and environmental relevance. It is an alternative technique to reduce the volume of sludge produced on a large scale, allowing its correct disposal and minimizing the environmental impacts resulting from improper disposal in the environment.

\section{Acknowledgments}

The authors wish to thank the Federal Center of Technological Education of Minas Gerais, CEFET-MG, Research Foundation of the State of Minas Gerais,
FAPEMIG, and the National Counsel of Technological and Scientific Development, CNPq, for the financial support.

\section{References}

Andreoli, C.V. (coordenador) (2001) Resíduos Sólidos do Saneamento: Processamento, Reciclagem e Disposição Final. Projeto PROSAB/ABES/RiMa, Rio de Janeiro, 282 pp.

ABNT (2013) Geossintéticos: Termos e Definições - NBR ISO 10318. Associação Brasileira de Normas Técnicas, Rio de Janeiro, Brasil, 22 pp.

ASTM (2011) Standard Test Method for Determining the Flow Rate of Water and Suspended Solids from a Geotextile Bag - D 7701. ASTM International, West Conshohocken, Pennsylvania, USA, 7 pp.

Barbosa, J.A. (2011) Análise laboratorial da eficiência de sistemas fechados de geotêxteis no desaguamento de lama de rocha fosfática, Dissertação de Mestrado, Departamento de Engenharia Civil, Centro Federal de Educação Tecnológica de Minas Gerais, Belo Horizonte, 115 pp.

Bittar, R.J.; Gomes, R.C.; Melo, L.C.Q.C. \& Martins, P.M. (2010) Feasibility studies for phosphate fine tailing disposal in geotêxtil tubes. Proc. 9th International Conference on Geosynthetics, Geosynthetics for a Challenging World, Guarujá, v. 3. pp. 1111-1114.

Bogossian, F.; Smith, R.T.; Vertematti, J.C. \& Yabek, O. (1982) Continuous retaining dikes by means of geotextiles. Proc. 2nd Conference on Geotextiles, Las Vegas, pp. 211-216.

Cantré, S. \& Saathoff, F. (2011) Design parameters for geosynthetic dewatering tubes derived from pressure filtration tests. Geosynthetics International, v. 18:3, p. $90-103$.

Castro, N.P.B. (2005) Tubular Sistemas Tubulares para Contenção de Lodo e Sedimentos Contaminados. Dissertação de Mestrado, Departamento de Engenharia Civil, Instituto Tecnológico de Aeronáutica, São José dos Campos, 103 pp.

Castro, N.P.B.; Melo, L.C.Q.C. \& Escobar, L.G.B (2008) Environmental integrated solution for septic tank sludge and landfill leachate using geotextile tubes dewatering technology. Proc. The First Pan American Geosynthetics Conference and Exhibition, Cancun, pp. 419-424.

Castro, N.P.B.; Martins, P.M.; Stephens, T. \& Melo, L.C.Q.C. (2009) Tests to Evaluate Dewatering and Filtration Efficiency for Geotextile Tubes Design. Proc. Geosynthetics 2009, Salt Lake City, Utah, 9 pp.

Christopher, B.R.; Holtz, R.D. \& Fischer, G.R. (1993) Research needs in geotextile filter design. In: Brauns, J.; Heibaum, M. \& Schuler, U. (eds) Filters in geotechnical and hydraulic engineering. Proc. First International Conference Geofilters, Karlsruhe, p. 19-26. 
Escobar, L.G.B.; Ribeiro, J.A.M.; Castro, N.P.B. \& Melo, L.C.Q (2010) Dewatering of contaminated materials with high moisture content in a short period of time using geotextile tubes in Camaçari, Brazil. Proc. 9th International Conference on Geosynthetics, Geosynthetics for a Challenging World, Guarujá, v. 3. p. 1309-1312.

Fontana, A.O. \& Cordeiro, J.S. (2005) Gestão Integrada como Busca de Solução para Rejeitos de ETA's - O Caso de Cardoso - SP. Proc. $23^{\circ}$ Congresso Brasileiro de Engenharia Sanitária e Ambiental, CD-ROM, Campo Grande, Mato Grosso do Sul, 10 pp.

Fowler, J.; Bagby, R.M. \& Trainer, E. (1996) Dewatering sewage sludge with geotextile tubes. Proc. 49th Canadian Geotechnical Conference, St. John's New Foundland, $30 \mathrm{pp}$.

Fowler, J.; Duke, M.; Schimidt, C.B.; Bagby, R.M. \& Trainer, E. (2002) Dewatering sewage sludge and hazardous with geotextile tubes. Proc. 7th International Conference on Geosynthetics, Nice, p. 1007-1012.

GRI (2004) Standard Test Method for the Hanging Bag Test for Field Assessment of Fabrics Used for Geotextile Tubes and Containers - GRI-GT14. Geosynthetics Research Institute, Folsom, PA, United States of America, 9 pp.

GRI (2009) Standard Test Method for the Pillow Test for Field Assessment of Fabrics/Additives Used for Geotextile Bags, Containers, and Tubes - GRI-GT15. Geosynthetics Research Institute, Folsom, PA, United States of America, 9 pp.

Giroud, J.P.; Delmas, P. \& Artieres, O. (1998) Theoretical basis for development of a twolayer geotextile filter. Proc. 6th International Conference on Geosynthetics, Atlanta, p. 1037-1044.

Gomes, R.C. (2007) Sistemas de disposição de rejeitos de mineração utilizando geotubos como estruturas de desaguamento e/ou de contenção. Proc. $5^{\circ}$ Simpósio Brasileiro de Geossintéticos/REGEO, CD-ROM, Recife, $8 \mathrm{pp}$.

Guanaes, E.A. (2009) Análise Laboratorial do Desaguamento do Lodo Residual de Estação de Tratamento de Água por Meio de Geossintéticos. Dissertação de Mestrado, Departamento de Engenharia Civil, Centro Federal de Educação Tecnológica de Minas Gerais, Belo Horizonte, 129 pp.

Guimarães, M.G.A; Urashima, D.C. \& Vidal, D. (2012) Evaluation the performance of closed geotextiles system for the waste dewatering of water treatment plant (WTP) - The efficacy dewatering. Proc. Second Pan American Geosynthetics Conference \& Exhibition/ GeoAmericas 2012, Lima, 8 pp.

Hoppen, C.; Andreoli, C.V.; Portella, K.F.; Sales, A. \& Joukoski, A. (2003) Estudo da incorporação do lodo centrifugado da estação de tratamento de Água Passaúna em matriz de concreto, com dosagem de 3\%. Proc. $22^{\circ}$ Congresso Brasileiro de Engenharia Sanitária e Ambiental, CD-ROM, Joinville, Santa Catarina, 10 pp.

Hoppen, C.; Portella, K.F.; Joukoski, A.; Baron, O.; Franck, R.; Sales, A.; Andreoli, C.V. \& Paulon, V.A. (2005) Co-disposição de lodo centrifugado de Estação de Tratamento de Água (ETA) em matriz de concreto: método alternativo de preservação ambiental. Cerâmica, n. 51, p. 85-95.

Koerner, R.M. (2005) Design with Geosynthetics. Fifty Edition. Prentice Hall, Upper Saddle River, 818 pp.

Koerner, G.R. \& Koerner, M.R. (2006) Geotextile tube assessment using a hanging bag test. Geotextiles and Geomembranes, v. 24:2, p. 129-137.

Lawson, C.R. (2008) Geotextile containment for hydraulic and environmental engineering. Geosynthetics International, v. 15:6, p. 384-427.

Leshchinsky, D. \& Leshchinsky, O. (2002) GeoCoPS (2.0): Suplemental Notes. ADAMA Engineering, Inc, Newark, 24 pp.

Leshchinsky, D.; Leshchinsky, O.; Ling, H.I. \& Gilbert, P.A. (1996) Geosynthetic Tubes for Confining Pressurized Slurry: Some Design Aspects. Journal of Geothechnical Engineering, p. 682-690.

Liao, K. \& Bathia, S.K. (2008) Geotextile tube dewatering: filtration criteria. Proc. The First Pan American Geosynthetics Conference \& Exhibition, Cancun, pp. 506513.

Martins, P.M. (2006) Utilização de Tubos Geotêxteis para Desaguamento de Rejeitos de Mineração. Dissertação de Mestrado, Departamento de Engenharia Civil, Instituto Tecnológico de Aeronáutica, São José dos Campos, $161 \mathrm{p}$.

Mendes, R.L.; Ferreira Filho, S.S; \& Scian, J.B. (2001) Desaguamento Mecânico por Filtro Prensa de Lodos Gerados em Estações de Tratamento de Água. Proc. $21^{\circ}$ Congresso Brasileiro de Engenharia Sanitária e Ambiental, CD-ROM, João Pessoa, Paraíba, Brasil, 10 pp.

Moo-Young, H.K.; Gaffney, D.A. \& Mo, X. (2002) Testing Procedures to assess the viability of dewatering with geotextiles tubes. Geotextiles and Geomembranes, v. 20, p. 289-303.

Moo-Young, H.K. \& Tucker, W.R. (2002) Evaluation of vacuum filtration testing for geotextile tubes. Geotextiles and Geomenbranes, v. 20, p. 191-212.

Muñoz, C.S. (2005) Desempenho de Geotêxteis na Filtração de Solos Internamente Instáveis. Dissertação de Mestrado, Departamento de Engenharia Civil, Instituto Tecnológico de Aeronáutica, São José dos Campos, $119 \mathrm{pp}$.

Muthukumaran, A.E. \& Ilamparuthi, K. (2006) Laboratory studies on geotextile filters as used in geotextile tube dewatering. Geotextiles and Geomenbranes, v. 24, p. 210-219.

Oliveira, E.M.S.; Machado, S.Q. \& Holanda, J.N.F. (2004) Caracterização de resíduo (lodo) proveniente de estação 
de tratamento de águas visando sua utilização em cerâmica vermelha. Cerâmica, v. 50, p. 324-330.

Pilarczyk, K.W. (2000) Geosynthetics and Geosystems in Hydraulic and Coastal Engineering. A.A. Balkema, Roterdam, Netherlands, 936 pp.

Reali, M.A.P. (coordenador) (1999) Noções Gerais de Tratamento e Disposição Final de Lodos de Estações de Tratamento de Água. Rede Corporativa de Pesquisas, Projeto PROSAB, ABES, Rio de Janeiro, 240 pp.

Satyamurthy, R. (2008) Experimental Investigations of Geotextile Tube Dewatering. PhD Dissertation, Syracuse University, Syracuse, Nova York, 233 pp.

Satyamurthy, R. \& Bhatia, S.K. (2009a) Experimental evaluation of geotextile dewatering performance. Proc. Geosynthetics 2009, Utah, p. 464-473.

Satyamurthy, R. \& Bhatia, S.K. (2009b) Effect of polymer conditioning on dewatering characteristics of fine sediment slurry using geotextiles. Geosynthetics International, v. 16:2, p. 83-96.

Shukla, S.K. \& Yin, J.H. (2006) Fundamentals of Geosynthetic Engineering. Taylor \& Francis Group, Balkema, The Netherlands, $428 \mathrm{pp}$.

Ten Cate (2010) Seaming of Geosynthetics. Technical Note, Ten Cate Geosynthetics North America, Pendergrass, GA, $12 \mathrm{p}$.

Tominaga, E. (2010) Análise dos Procedimentos para Avaliação de Desempenho de Sistemas Fechados com Geotêxtil para Desaguamento. Master Dissertation. Departamento de Engenharia Civil, Instituto Tecnológico de Aeronáutica, São José dos Campos, 126 pp.

Trentini, R.S., Vidal, D.M. \& Martins, P.M. (2006) Chemical ageing and creep analyses - influence of synergy and test specimen preparation. Proc. 8th International Conference on Geosynthetics, Rotterdam, v. 4. p. 16091612.

Tsutuya, M.T. \& Hirata, A.Y. (2001) Aproveitamento e disposição final de lodos de estação de tratamento de água do Estado de São Paulo. Proc. 21 ${ }^{\circ}$ Congresso Brasileiro de Engenharia Sanitária e Ambiental, CD-ROM, João Pessoa.

Umezaki, T. \& Kawamura, T. (2002) Techniques of dewatering and volume reduction of surplus with high water content using vaccum consolidation method with paper bag. Proc. Symposium of Ground Improvement, v. 7, p. 59-64 (in Japanese).

Urashima, D.C. (2002) Simulação do Processo de Retenção de Partículas por Filtros Têxteis. Tese de Doutorado, Instituto Tecnológico de Aeronáutica, São José dos Campos, 199 pp.

Urashima, D.C.; Guanaes, E.A.; Guimarães, M.G.A.; Pontes, P.P. \& Vidal, D.M. (2010) Laboratory studies on geotextiles tubes dewatering by pressure filtration test in reduced model. Proc. 9th International Conference on Geosynthetics, Geosynthetics for a Challenging World, Guarujá, v. 2, p. 951-954.

Vidal, D.M.; Fabrin, T. \& Montez, F.T. (1999) O Conceito de Fatores de Redução Aplicados às Propriedades dos Geossintéticos. Proc. I Simpósio Sul-Americano de Geossintéticos / $3^{\circ}$ Simpósio Brasileiro de Geossintéticos, Rio de Janeiro, v. 1, p. 189-198.

Vidal, D.M. \& Urashima, D.C. (1999) Dimensionamento de filtros e drenos em geossintéticos. Proc. Simpósio Sul-Americano de Geossintéticos, CD-ROM, Rio de Janeiro, 16 pp. 



\title{
Surprising Soil Behaviour in Soil Sampling
}

\author{
G.M.F. Jannuzzi, F.A.B. Danziger, I.S.M. Martins
}

\begin{abstract}
Thick wall (6.6 mm wall thickness) plastic samplers, $97.2 \mathrm{~mm}$ in internal diameter (area ratio of 29\%), $700 \mathrm{~mm}$ in length (length of soil sample $640 \mathrm{~mm}$ ), with a cutting edge angle of $23^{\circ}$, without clearance and with a sampler head have been used to collect very soft clay samples at Sarapuí II test site. Very good to excellent and good to fair quality samples have been surprisingly obtained in most cases, which were attributed to a combination of five factors: the absence of an inside clearance, the low friction of the plastic sampler, the small "trick" to close the top of the sampling rods assuring that suction would be imposed on the top of the sample, the very careful handling and trimming process, combined with no extrusion of the sample, and the small ratio between specimen diameter and sample diameter. It is still too early to propose the use of thick wall plastic samplers - in combination with the procedures outlined above - to be used in regular undisturbed soft clay sampling, and more research is needed to identify the role of each procedure in the final result. However, if confirmed, the procedures adopted will allow significant cost saving with respect to the use of thin wall brass (or stainless steel) samplers.
\end{abstract}

Keywords: sampling, soft clay, sample quality.

\section{Introduction}

It is well known that the quality of the sample plays an important role on the results of laboratory tests. There are several types of samplers to collect samples of soft clay, both onshore and offshore.

The Sherbrooke sampler (Lefebvre \& Poulin, 1979) is generally considered the best onshore sampler (e.g., Hight et al., 1992), since a block sample with a large diame$\operatorname{ter}(250 \mathrm{~mm})$ is carved into the soil. However, when used in very soft soils it might be unsuitable, since it does not have a lateral support and the sample is retrieved mostly by the diaphragm that cuts the soil at the bottom of the sampler. Therefore, when the block is retrieved, failure of the sample due to its self-weight may occur, as observed by Oliveira (2002) when sampling in a very soft clay at Barra da Tijuca, Rio de Janeiro.

Piston samplers are generally considered able to provide good quality samples (e.g., Lunne et al., 1997, Tanaka \& Nishida, 2007), both when displacement method and preaugering are used. However, they are more difficult to operate than simple thin wall tubes (or Shelby tubes). Although piston samplers have been used in Brazil for a long time (e.g., Costa Filho et al., 1977, Lacerda et al., 1977), the Brazilian practice has been mostly related to the use of thin wall tubes, fitted with a sampler head with a suction ball valve to help keeping the sample during recovery.

A number of authors (e.g., Hvorslev, 1949, Kallstenius, 1963, Lefebvre \& Poulin, 1979, La Rochelle et al., 1981, Baligh et al., 1987, Hight et al., 1992, Tanaka \& Tanaka, 1999) have studied the factors that affect the quality of the sample. Lunne \& Long (2006) have recently re- viewed the role of the sampler characteristics, as listed below, in the sample quality:

- Sample diameter;

- Wall thickness;

- Cutting edge angle;

- Inside clearance;

- Inside friction;

- Outside friction.

Reference must be made to Lunne \& Long (2006) to a detailed analysis of each factor. Very briefly it must be stated that the larger the sample diameter, the smaller the wall thickness and the cutting edge angle the better the quality of the sample. Concerning the sample diameter, the Brazilian standard NBR 9820 (1997) is more stringent than other standards, once the minimum external diameter allowed for sampling in regular conditions is $100 \mathrm{~mm}$. In fact, samplers with $75 \mathrm{~mm}$ in diameter are commonly used in many countries (Lunne \& Long, 2006).

The presence of an inside clearance is still an issue. Numerical analyses have indicated (e.g., Baligh et al., 1987, Clayton et al. 1998) that inside clearance might be responsible for sample disturbance. Some well-known samplers do not have internal clearance, such as the Laval sampler (La Rochelle et al., 1981) and the Japanese thin wall standard piston sampler (Tanaka \& Tanaka, 1999). However, once the main purpose of the inside clearance is to reduce the inside friction, a number of samplers do have an internal clearance, especially when long samples are to be retrieved, as in the case of offshore samplers (Lunne \& Long, 2006).

As mentioned before, inside friction is one of the main causes of disturbance, and the smaller the inside fric-

G.M.F. Jannuzzi, MSc, PhD Student, Research and Teaching Assistant, COPPE and Escola Politécnica, Universidade Federal do Rio de Janeiro, Rio de Janeiro, RJ, Brazil. e-mail: jannuzzi@coc.ufrj.br.

F.A.B. Danziger, DSc, Associate Professor, COPPE and Escola Politécnica, Universidade Federal do Rio de Janeiro, Rio de Janeiro, RJ, Brazil. e-mail: danziger@ coc.ufrj.br. Ian Schumann Marques Martins, DSc, Associate Professor, COPPE and Escola Politécnica, Universidade Federal do Rio de Janeiro, Rio de Janeiro, RJ, Brazil. e-mail: ian@ coc.ufrj.br. Submitted on January 24, 2013; Final Acceptance on September 27, 2013; Discussion open until April 30, 2014. 
tion the better the quality of the sample. Outside friction must also be reduced, once it is able to generate shearing stresses in the soil below the cutting edge (Eide \& Andresen, 1977).

\section{Evaluation of Sample Quality}

Specimen can be defined as the portion of the soil trimmed from the sample to be used to carry out the test. Therefore, it must be pointed out that what is called sample quality is indeed specimen quality in most cases, provided that the final evaluation is carried out on the specimen, and not on the sample. However, once the designation sample quality is broadly used in the technical literature, it will be kept in the present paper.

The sample quality depends on a number of factors, from the sample retrieval from the ground (which affecting factors were presented in the previous section) until the extrusion (when performed), final trimming and positioning into the test apparatus. Sample extrusion, although carried out routinely, has been questioned and a procedure in which the tube sample is cut in short lengths has been proposed (Germaine, 2003, quoted by Ladd \& DeGroot, 2003), as illustrated in Fig. 1.

No definitive method exists to determine the absolute sample quality (Ladd \& DeGroot, 2003). The influence of sample disturbance in consolidation tests has been studied for a long time (e.g., Schmertmann, 1953). Sample disturbance reduces the yield stress, $\sigma_{v m}^{\prime}$, (or the overconsolidation ratio, OCR) and the compression index, $C_{c}$, in the range of lower effective stresses. Moreover, the " $\mathrm{S}$ " shaped

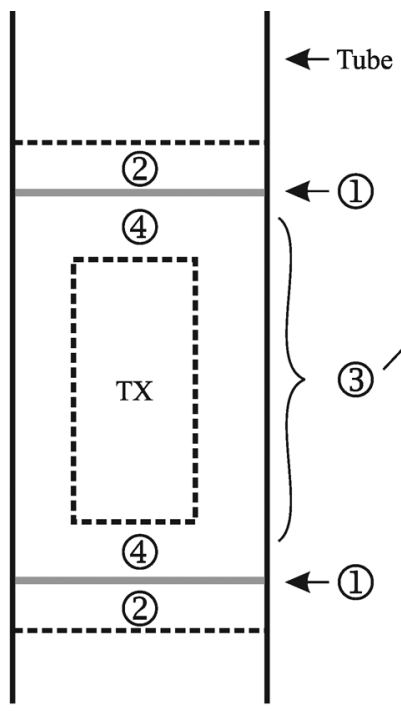

(1) Cut tube soil with horizontal band saw

(2) W, and $2+/$ - torvane tests, remove clay, seal with wax (50/50 paraffin and petroleum jelly: LaRochelle et. al. 1986) and caps curve for a good sample is "smoothed", as illustrated e.g. by Coutinho (1976) for the Sarapuí soft clay (Fig. 2).

The observations above are of qualitative nature. Quantitative criteria to evaluate the sample quality have been proposed, and the one suggested by Lunne et al. (1997) is very much used nowadays (Table 1). This criterion is based on the $\Delta \mathrm{e} / \mathrm{e}_{\mathrm{o}}$ ratio, where $\Delta \mathrm{e}=\mathrm{e}-\mathrm{e}_{\mathrm{o}}$ is the difference between the void ratio at the vertical effective stress in the field, e, and the initial void ratio, $\mathrm{e}_{\mathrm{o}}$.

The use of the criterion included in Table 1 implies the need of performing the tests. The evaluation of the sample quality prior to the tests can be done, and X-ray pictures have been used for many years (e.g., Hvorslev, 1949). Measurements of initial suction in the sample, comparison of shear wave velocity measured on the specimen with that obtained in situ have also been used (e.g., Hight \& Leroueil, 2003, Landon, 2004, Lunne \& Long, 2006, Tanaka \& Nishida, 2007).

\section{Sample Quality of Brazilian Soft Clays}

Oliveira (2002) and Coutinho (2007) considered that the limits established by Lunne et al. (1997) are too strict to the very soft plastic organic Brazilian clays, and suggested to release them (Table 2). Andrade (2009) proposed more classes in the modified criterion (Table 3 ).

\section{Surprising Behaviour}

\subsection{General}

According to the Brazilian standard NBR 9820 (1997) the tube samplers do need to have a clearance. As

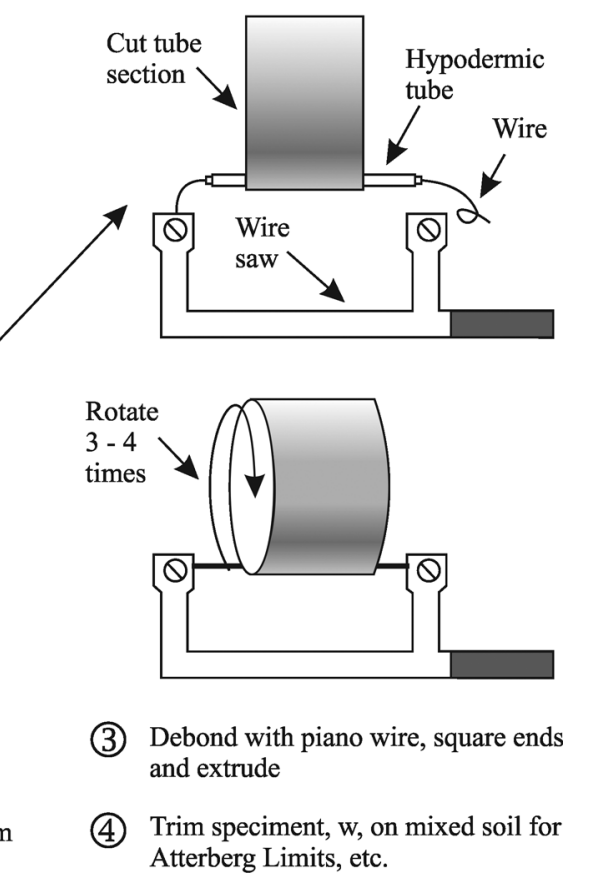

Figure 1 - Procedure for obtaining test specimen from tube sample (Germaine, 2003, after Ladd \& DeGroot, 2003). 
previously shown, the presence of the clearance is still an issue. Therefore it has been argued by the authors of the present paper that the presence of the clearance would be

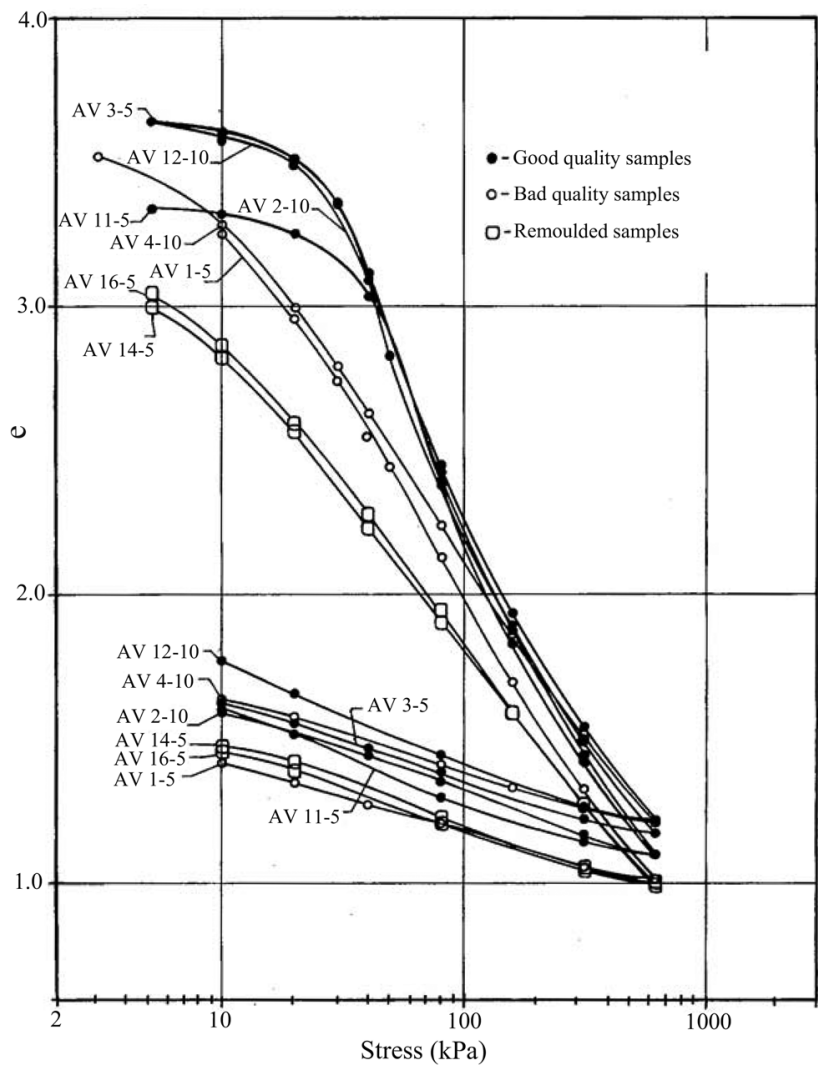

Figure 2 - Influence of sample disturbance in consolidation tests in the case of Sarapuí soft clay (adapted from Coutinho, 1976). responsible for the classification very good to excellent seldom being obtained for Brazilian samples, which led to the suggestions to release the Lunne et al. (1997) criterion presented in the previous section. In other words, the need for releasing the Lunne et al. (1997) criterion would be a consequence of the sampling procedure and not a consequence of the characteristics of the Brazilian very soft clays. It must be pointed out that a piston sampler similar to the Japanese sampler, $76 \mathrm{~mm}$ in diameter, $1 \mathrm{~m}$ in length and no inside clearance was developed by Bertuol et al. (2010) and successfully used in a very soft clay from Rio Grande do Sul, south of Brazil.

Besides, as mentioned in section 1, although piston samplers have been used in Brazil, this kind of sampler demands a procedure which is not straightforward, and thin wall tubes, fitted with a sampler head to help keeping the sample during sample recovery, are commonly used. However, the use of thin wall tubes might demand a significant time to guarantee the proper retrieval of the sample. In fact, hours are needed in some cases to allow the pore pressure generated during the penetration of the tube sampler to dissipate and provide the necessary strength on the soil at the contact with the tube.

In order to solve this problem, and still keeping the simplicity of the operation, a new sampler is under development at COPPE, Federal University of Rio de Janeiro. This new sampler will cut the sample from the bottom as done by the Sherbrooke sampler.

To compare the quality of the samples from the new sampler, sampling series were planned. The first series of tests would be performed with a thick wall plastic tube sampler $(97.2 \mathrm{~mm}$ in internal diameter, $6.6 \mathrm{~mm}$ in wall thick-

Table 1 - Lunne et al. (1997) criterion to evaluate sample disturbance.

\begin{tabular}{lcccc}
\hline OCR & \multicolumn{3}{c}{$\Delta{\mathrm{e} / \mathrm{e}_{\mathrm{o}}}$} \\
\cline { 2 - 5 } & Very good to excellent & Good to fair & Poor & Very poor \\
\hline $1-2$ & $<0.04$ & $0.04-0.07$ & $0.07-0.14$ & $>0.14$ \\
$2-4$ & $<0.03$ & $0.03-0.05$ & $0.05-0.10$ & $>0.10$ \\
\hline
\end{tabular}

Table 2 - Lunne et al. (1997) criterion to evaluate sample disturbance modified by Oliveira (2002) and Coutinho (2007).

\begin{tabular}{cccccc}
\hline \multirow{2}{*}{ OCR } & \multicolumn{4}{c}{$\Delta \mathrm{e} / \mathrm{e}_{\mathrm{o}}$} \\
\cline { 2 - 5 } & Very good to excellent & Good to fair & Poor & Very poor \\
\hline $1-2.5$ & $<0.05$ & $0.05-0.08$ & $0.08-0.14$ & $>0.14$ \\
\hline
\end{tabular}

Table 3 - Lunne et al. (1997) criterion to evaluate sample disturbance modified by Andrade (2009).

\begin{tabular}{ccccccc}
\hline OCR & \multicolumn{5}{c}{$\Delta \mathrm{e}_{\mathrm{e}}$} \\
\cline { 2 - 6 } & Very good to excellent & Very good to good & Good to fair & Fair to poor & Poor to very poor & Very poor \\
\hline $1-2.5$ & $<0.05$ & $0.05-0.065$ & $0.065-0.08$ & $0.08-0.11$ & $0.11-0.14$ & $>0.14$ \\
\hline
\end{tabular}




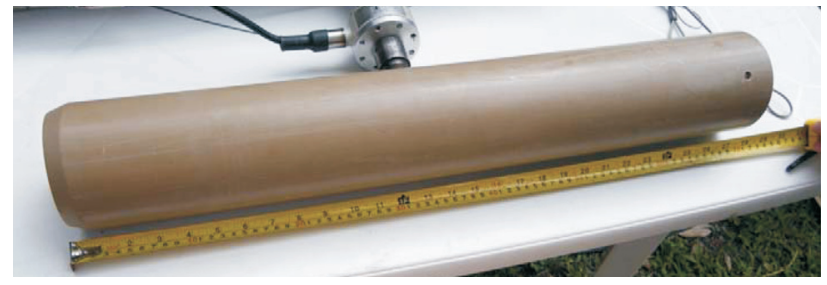

Figure 3 - Thick wall plastic sampler.

ness, area ratio of $29 \%$ ), with a cutting edge of $23^{\circ}$, without clearance. The sampler length is $700 \mathrm{~mm}$, and the length of soil sample is $640 \mathrm{~mm}$ (Fig. 3). A sampler head regularly used with thin wall samplers was machined to fit in the thick wall plastic sampler (Fig. 4).

Poor quality samples were expected to be obtained, which would be in between the 2 extremes of the very good to excellent quality samples expected with the new sampler and the very poor quality samples obtained by a process of completely remoulding in the laboratory. However, this was not verified, as shown below, and very good to excellent and good to fair quality samples were surprisingly obtained in most cases with the thick wall plastic sampler.

\subsection{The test site}

The Sarapuí soft clay test site has been used since the 1970's as a research site, and a number of in situ and laboratory tests have already been performed (e.g., Lacerda et al., 1977, Werneck et al., 1977, Ortigão et al., 1983). A general report about the deposit was provided by Almeida \& Marques (2003). In the last fifteen years, however, security reasons have prevented the use of the test site. A new area (named Sarapuí II) in the same deposit, $1.5 \mathrm{~km}$ from the previous area and inside a Navy Facility, has been used since then (Fig. 5). Two researches on pile behaviour have been carried out at the Sarapuí II site (Alves, 2004, Francisco, 2004, Alves et al., 2009). The initial tests with the torpedo-piezocone (Porto et al., 2010, Jannuzzi et al., 2010,

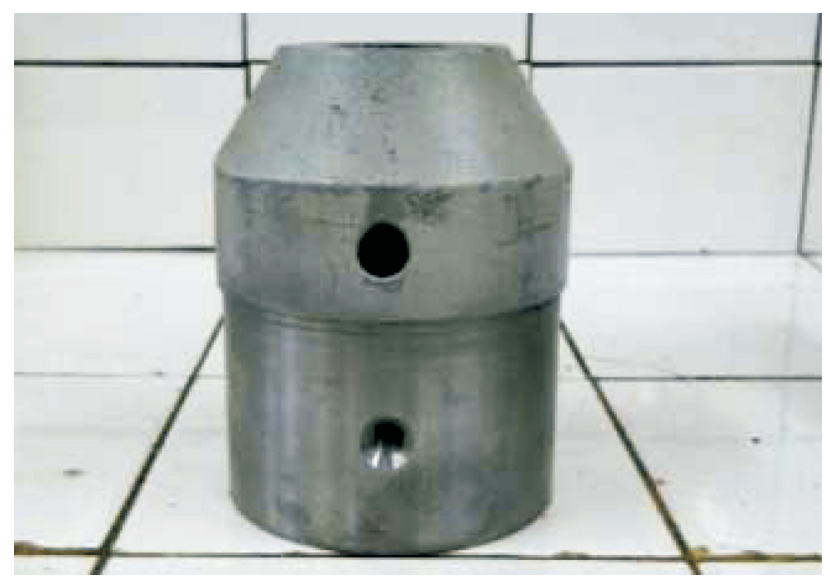

Figure 4 - Sampler head regularly used with thin wall brass sampler machined to be used with the thick wall plastic sampler.

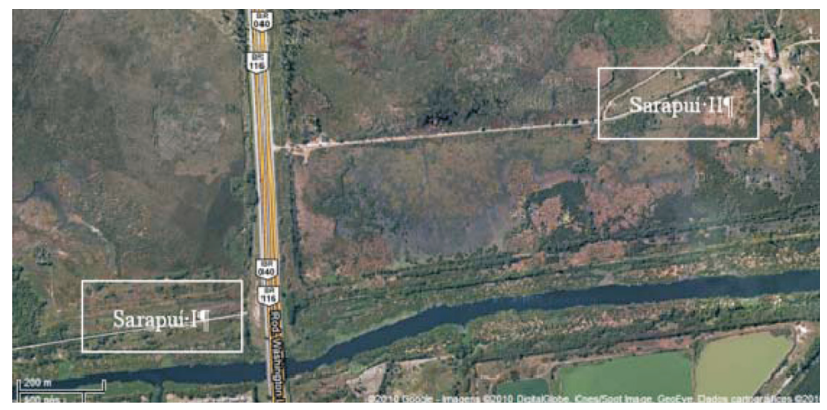

Figure 5 - Sarapuí II test site with respect to the early Sarapuí I test site.

Henriques Jr. et al., 2010) were also performed at Sarapuí II test site.

A number of in situ tests have been performed at Sarapuí II. In fact, 9 boreholes for SPTs (performed each meter in Brazil), 7 CPTUs, 51 vane tests (in 5 deployments), 4 T-bar tests and 4 SDMT tests were conducted (Jannuzzi, 2009, 2013), both in natural soil and under an old embankment (Jannuzzi et al., 2012). The very soft clay material in this particular area varies from $6.5 \mathrm{~m}$ to $10 \mathrm{~m}$. The Atterberg limits, natural water content and specific gravity are shown in Fig. 6 and a typical piezocone test in Fig. 7.

\subsection{Samples collected}

\subsubsection{General}

Once the aim of the sampling series with the plastic thick wall sampler was to allow a comparison with the new sampler, the same procedure to collect the samples in the case of thin wall brass sampler regularly used at COPPE, Federal University of Rio de Janeiro and by many other institutions was used. In other words, care was taken with respect to all sampling steps, whenever possible. This includes:

i) Proper cleaning of the sampler prior to its insertion into the ground;

ii) Proper cleaning of the borehole; this was not always achieved, because of the way it is regularly executed, by wash boring and using a sharp cutting metallic device with 2 jetting bits, manually controlled, precludes careful control of the excavation of the borehole;

iii) Proper control of the rate of penetration of the sampler, with a device adapted at the tripod regularly used to perform SPT in Brazil. Although this procedure had already been used in the past, the most common procedure is to simply push the rod stem with the sampler manually;

iv) Proper control of the penetrated length of the sampler;

v) Care when retrieving the sampler;

vi) Proper handling, storage and transportation to the laboratory.

Samples were collected every $0.5 \mathrm{~m}$ in 2 deployments, in order to cover the whole profile. Six samples were 


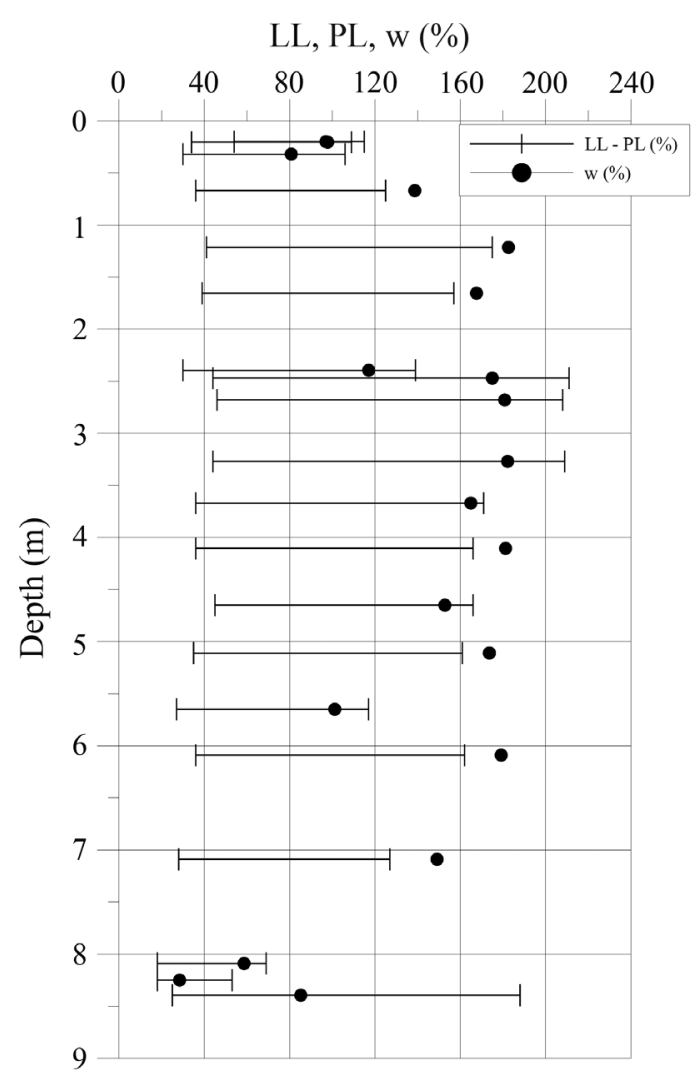

(a)

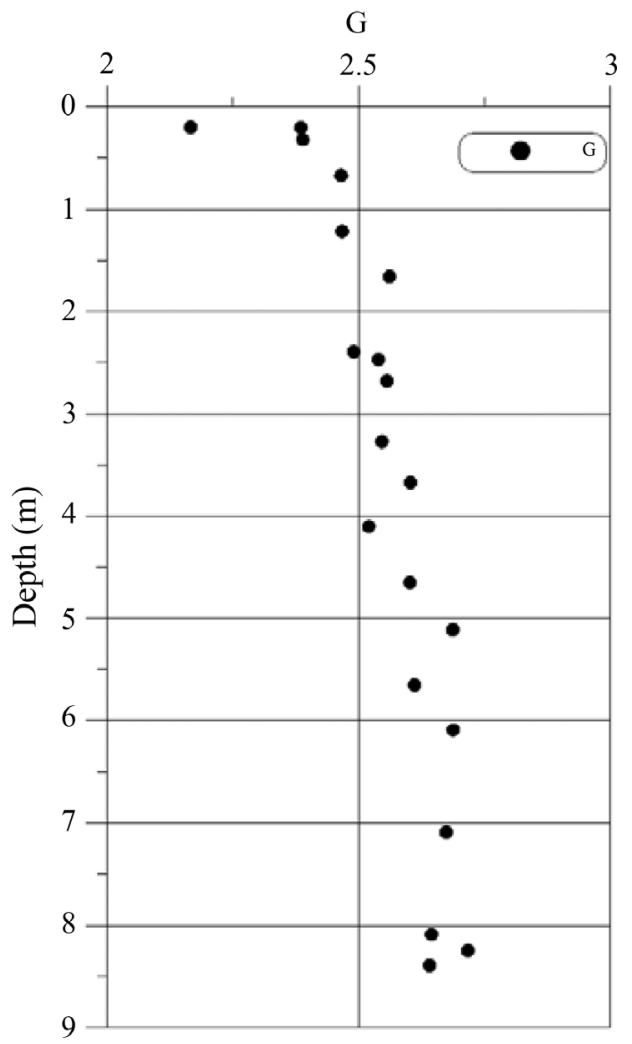

(b)

Figure 6 - (a) liquid limit (LL), plastic limit (PL) and natural water content (w); (b) specific gravity (G) from Sarapuí II test site.

randomly chosen to be used for consolidation tests, and the average depth of the corresponding specimens are $1.06 \mathrm{~m}$, $2.10 \mathrm{~m}, 3.09 \mathrm{~m}, 4.24 \mathrm{~m}, 5.40 \mathrm{~m}$ and $7.44 \mathrm{~m}$.

\subsubsection{Handling and trimming in laboratory}

A procedure similar to the one described in section 2 and illustrated in Fig. 1 has been used for a number of years at the Rheology Laboratory of the Group of Geotechnical Laboratories Jacques de Medina, at COPPE, Federal University of Rio de Janeiro. This procedure is illustrated below, see also Aguiar (2008) and Andrade (2009). The first step is to cut a desired slice of the sampler with a band saw (Fig. 8), which must be done with a proper support. The sampler is turned while it is cut, in order not to cut the sample. Despite the thick wall, the procedure is much easier and faster than with the thin brass sampler. Then the sample is cut with a thin guitar string. The next step is to carefully introduce the guitar string, driven by a long thick needle, longitudinally into the slice produced, as shown in Fig. 9.

Then the string is used to separate the sample from the sampler slice by a number of rotations, typically 4 . This procedure also provides room for driving the consolidation ring without bulges at the top of the sample. In the case of consolidation tests, the consolidation ring $(71.4 \mathrm{~mm}$ in internal diameter) is then pushed into the sample with the aid of another ring. Thus, since the consolidation ring thickness is $1.2 \mathrm{~mm}$, the external $12 \mathrm{~mm}$ of the sample is removed (which is done in the last step). After this step the guitar string is used again, now in order to allow an easy extrusion of the sample from the sampler. The last step is removing the soil from the outside of the consolidation ring, using the removed material to determine the water content of the soil.

\subsection{Tests performed}

Incremental loading (IL) $24 \mathrm{~h}$ consolidation tests were conducted at the controlled temperature room of the Rheology Laboratory. The values of $\Delta \mathrm{e}_{\mathrm{e}}$ vs. depth are shown in Fig. 10a, where the Lunne et al. (1997) criterion is also indicated. Since the criterion depends on OCR, the obtained values are shown in Fig. 10b. It can be observed that very good to excellent quality was obtained for the samples at $1.06 \mathrm{~m}$ and $2.10 \mathrm{~m}$ depth, and good to fair at $3.09 \mathrm{~m}$ and $7.44 \mathrm{~m}$ depth. The samples at $4.24 \mathrm{~m}$ and $5.40 \mathrm{~m}$ depth did present very poor and poor quality respectively, which could be anticipated from the simple observation of the samples. In fact, it was later found that the method of excavating and cleaning the borehole by wash boring was not efficient at all, and soil from the excavation stayed in many cases inside the borehole, which could not be detected when positioning the sampler at the bottom of the borehole. This means that in these cases this remoulded material was sampled, not the natural soil. This was clearly the case of 


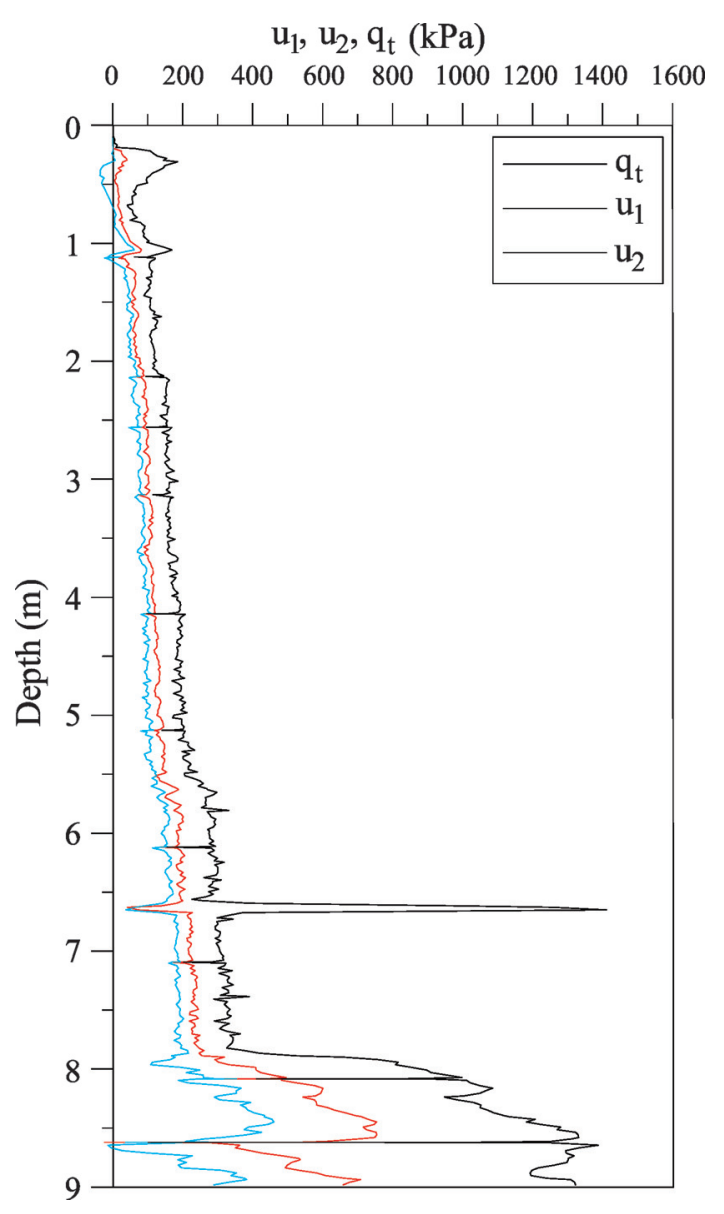

Figure 7 - Corrected cone resistance $\left(q_{\mathrm{f}}\right)$ and pore pressures at cone face $\left(\mathrm{u}_{1}\right)$ and cone shoulder $\left(\mathrm{u}_{2}\right)$ from typical piezocone test at the Sarapuí II test site.

the sample at $4.24 \mathrm{~m}$ depth. The specimen at $5.40 \mathrm{~m}$ contained a very significant amount of shells, part of which needed to be removed and the specimen completed with lumps of the sample.

The quality of the samples can also be inferred from the trend of OCR $v s$. depth, where it is clearly observed that the values of OCR for the samples at $4.24 \mathrm{~m}$ and $5.40 \mathrm{~m}$ are underestimated. The compression curve for the test at $2.10 \mathrm{~m}$ depth is shown in Fig. 11, where the very good to excellent quality of the sample can be observed by the shape of the curve.

\section{Discussion}

It might be argued that the surprisingly very good to excellent quality of the obtained samples may be attributed to the very low effective stresses, once the samples corresponding to $1.06 \mathrm{~m}$ and $2.10 \mathrm{~m}$ have provided the best results ( $\Delta \mathrm{e} / \mathrm{e}_{\mathrm{o}}$ of only 0.006 and 0.013 , respectively). It might also be argued that the Lunne et al. (1997) criterion is limited to $\mathrm{OCR}=4$, and the sample at $1.06 \mathrm{~m}$ (the best result) has an OCR of 8.5. However, the tests performed at $3.09 \mathrm{~m}$ and $7.44 \mathrm{~m}$ have also provided good to fair quality samples

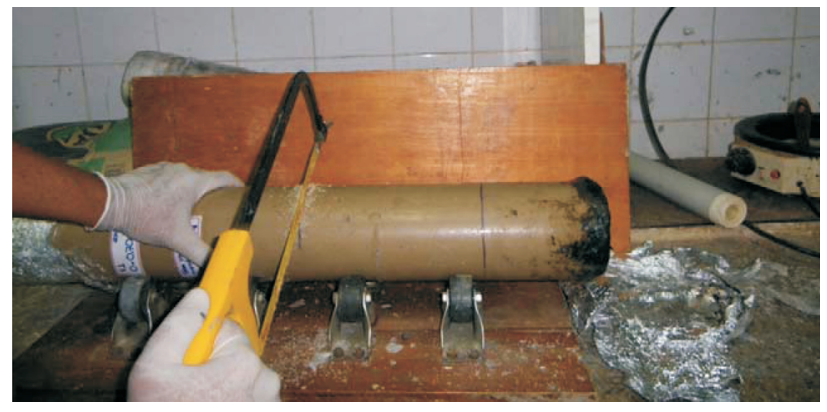

Figure 8 - Cutting the tube sampler with a band saw.

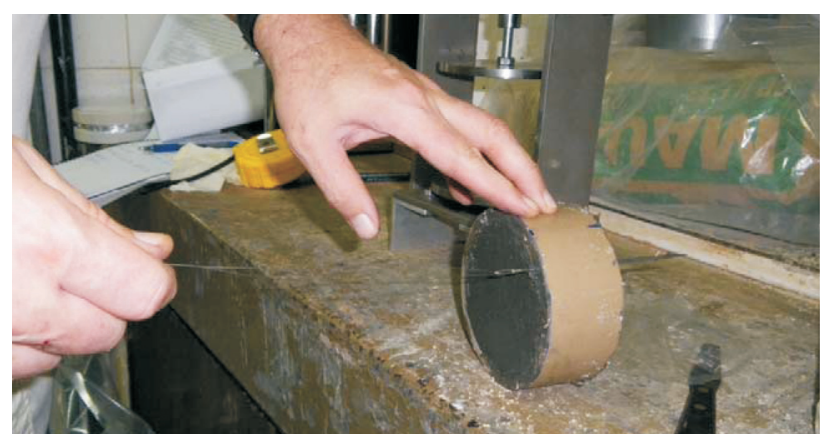

Figure 9 - Needle used to guide the introduction of a guitar string longitudinally into the sample.

according to the Lunne et al. (1997) criterion. On the other hand, it might be argued that the two samples which presented the very poor and poor results would have provided good to fair results in case the problems mentioned in the previous section did not occur. The results are indeed quite surprising, since the geometry of the sampler used do not fit into any suggestion of adequate geometry of samplers designed to get good samples, as e.g. the one by Andresen (1981), shown in Fig. 12. In fact, the cutting edge angle of $23^{\circ}$ is not even included in the chart.

In summary, it seems that the very good results obtained are due to the following reasons:

i) The absence of an inside clearance. The obtained results do indicate that the inside clearance should be avoided in onshore samplers, differently e.g. from the Brazilian standard.

ii) The low friction of the plastic sampler. As mentioned in Section 1, both the internal friction and the external friction affect the sample quality. In the case of the plastic sampler used the very low friction might have contributed to the obtained results.

iii) The small "trick" to close the top of the sampling rods, assuring that suction would be imposed on the top of the sample, reducing the risk of sample sliding inside the sampling tube.

iv) The very careful handling and trimming process, combined with no extrusion of the sample as in the traditional process. 

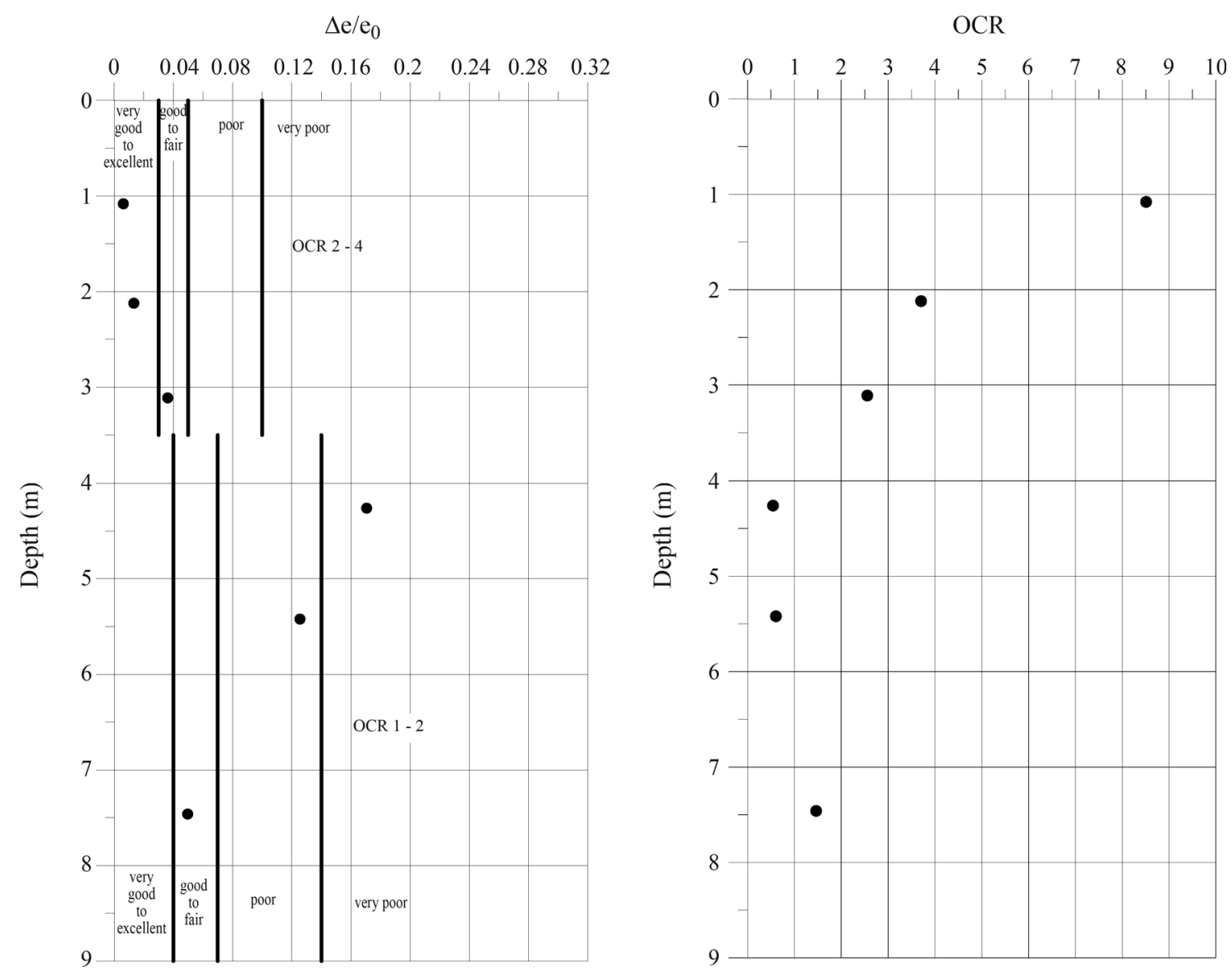

Figure 10 - (a) $\Delta \mathrm{e}_{\mathrm{e}} \mathrm{e}_{\mathrm{o}} v s$. depth for IL $24 \mathrm{~h}$ consolidation tests from specimens obtained from thick wall plastic sampler at Sarapuí II test site; (b) OCR vs. depth from the same specimens.

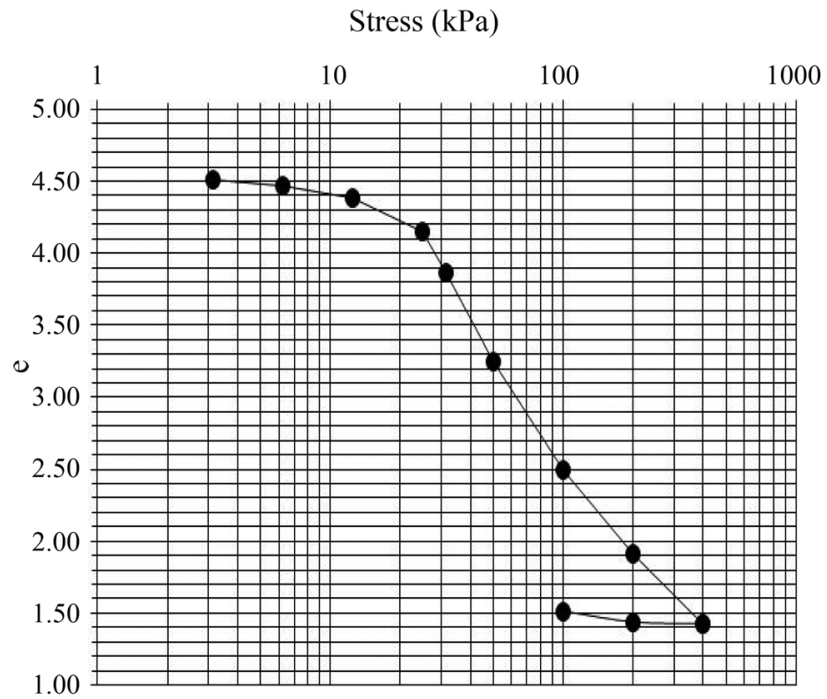

Figure 11 - Compression curve, specimen from $2.10 \mathrm{~m}$ depth.

v) The small ratio between specimen diameter and sample diameter, of 0.73 . Reference must be made to e.g., Bjerrum (1973), Lunne et al. (2006) and Tanaka \& Tanaka (2009) on this particular subject.

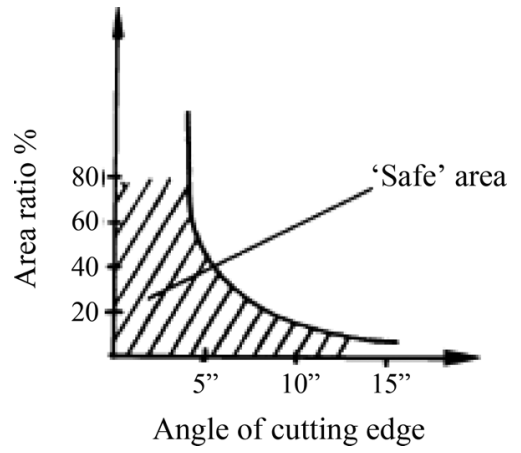

Figure 12 - Relationship between disturbance, cutting edge angle and area ratio (Andresen, 1981).

The combination of these five factors seems to be the key of the very good to excellent and good to fair unexpected quality of the samples obtained with the thick wall plastic sampler. It is still too early to propose the use of thick wall plastic samplers - in combination with the procedures outlined above - to be used in regular soil sampling to obtain undisturbed samples, and more research is needed to identify the role of each procedure in the final result. However, the results are encouraging enough to suggest the con- 
tinuation of the research. If confirmed, the procedures adopted will allow significant cost saving, once the brass sampler costs roughly 8 times more than the plastic sampler. Besides, cutting the thick wall plastic sampler in slices is much easier than the thin wall brass sampler, not only because of the effort needed in the procedure, but also because cutting the thin wall sampler must be done with care in order not to deform the sample.

Two points - working in opposite directions with respect to the sample quality evaluation of the tests performed in Sarapuí II soft clay - must still be considered for future research:

- The criterion proposed by Lunne et al. (1997) is based on CRS consolidation tests, not in IL tests. Since CRS tests generally produce strains smaller than IL tests, the values of $\Delta \mathrm{e} / \mathrm{e}_{\mathrm{o}}$ included in table 1 could be a little big larger for the case of IL tests.

- It has been found (e.g., Berre \& Bjerrum, 1973) that highly plastic clays are less subjected to disturbance than low plastic clays.

\section{Conclusions}

Surprisingly, very good to excellent and good to fair quality samples of the very soft plastic organic Sarapuí II clay have been obtained with a thick wall $(6.6 \mathrm{~mm}$ wall thickness) plastic sampler, $97.2 \mathrm{~mm}$ in internal diameter (area ratio of 29\%), $700 \mathrm{~mm}$ in length (length of soil sample $640 \mathrm{~mm}$ ) with a cutting edge angle of $23^{\circ}$ and no inside clearance, which were attributed to the combination of five factors: the absence of an inside clearance, the low friction of the plastic sampler, the small "trick" to close the top of the sampling rods assuring that suction would be imposed on the top of the sample, the very careful handling and trimming process, combined with no extrusion of the sample and the small ratio between specimen diameter and sample diameter.

It is still too early to propose the use of thick wall plastic samplers - in combination with the procedures outlined above - to be used in regular soil sampling to obtain undisturbed samples in soft clays, and more research is needed to identify the role of each procedure in the final result. However, the results are encouraging enough to suggest the continuation of the research. If confirmed, the procedures adopted will allow significant cost saving with respect to the use of thin wall brass (or stainless steel) samplers.

\section{Acknowledgments}

The authors would like to acknowledge the financial support provided by CENPES/PETROBRAS, and the permission of Comando da Estação Rádio da Marinha no Rio de Janeiro to use part of its facilities at BR-040 motorway as a geotechnical test site.
Tom Lunne, from the Norwegian Geotechnical Institute (NGI), reviewed the paper and offered very valuable comments.

\section{References}

Aguiar, V.N. (2008) Consolidation Characteristics of Santos Clay. M.Sc. Thesis, COPPE, Federal University of Rio de Janeiro, Rio de Janeiro, 223 pp. (in Portuguese).

Almeida, M.S.S. \& Marques, M.E.S. (2003) The Behaviour of Sarapuí Soft Clay. In T.S. Tan, K.K. Phoon, D.W. Hight, and S. Lerouell (eds) Characterisation and Engineering Properties of Natural Soils, Balkema, v. 1, pp. 477-504.

Alves, A.M.L. (2004) The Influence of Soil Viscosity and Time on the Dynamic Pile-Soil Interaction in Clays. D.Sc. Thesis, COPPE, Federal University of Rio de Janeiro, Rio de Janeiro (in Portuguese).

Alves, A.M.L.; Lopes, F.R.; Randolph, M.F. \& Danziger, B.R. (2009) Investigations on the dynamic behavior of a small-diameter pile driven in soft clay. Canadian Geotechnical Journal, v. 46:12 p. 1418-1430.

Andrade, M.E.S. (2009) Contribution to the Study of Santos Soft Clays. M.Sc. Thesis, COPPE, Federal University of Rio de Janeiro, Rio de Janeiro, 397 pp. (in Portuguese).

Andresen, A. (1981) Exploration, sampling and in-situ testing of soft clay. Soft clay engineering. In: Brand, E.W. \& Brenner, R.P.(eds) Developments in Geotechnical Engineering, v. 20. Elsevier, pp. 245-308.

Baligh, M.M.; Azzouz, A.S. \& Chin, C.T. (1987) Disturbance due to ideal tube sampling. Journal of the Geotechnical Engineering Division, ASCE, v. 113:GT7, p. 739-757.

Berre, T. \& Bjerrum, L. (1973) Shear strength of normally consolidated clays. Proc. VIII International Conference on Soil Mechanics and Foundation Engineering, Moscow, v. 1.1, pp. 39-49.

Bertuol, F.; Bressani, L.A. \& Bica, A.V.D. (2010) Geotechnical characterization of the sensitivity of a sedimentary soil from Rio Grande do Sul with a new sampler. Proc. X Brazilian Conference on Soil Mechanics and Geotechnical Engineering, Gramado, CD (in Portuguese).

Bjerrum, L. (1973) Problems of soil mechanics and construction on soft clays. State-of-the-art report to session. IV Proc. VIII International Conference on Soil Mechanics and Foundation Engineering, Moscow, v. 3, pp. 111-159.

Clayton, C.R.I.; Siddique, A. \& Hopper, R.J. (1998) Effects of sampler design on tube sampling disturbance - Numerical and analytical investigations. Géotechnique, v. 48:6, p. 847-867.

Costa Filho, L.M.; Werneck, M.L.G. \& Collet, H.B. (1977) The undrained shear strength of a very soft clay. Proc. 
IX International Conference on Soil Mechanics and Foundation Engineering, Tokio, v. 1, pp. 69-72.

Coutinho, R.Q. (1976) Consolidation Characterisitics with Lateral Drainage of a Soft Clay from Fluminense Plains. M.Sc. Thesis, COPPE, Federal University of Rio de Janeiro, Rio de Janeiro (in Portuguese).

Coutinho, R.Q. (2007) Characterization and Engineering Properties of Recife Soft Clays - Brazil. Characterization and Engineering Properties of Natural Soils, Taylor and Francis - Balkema, Editors Tan, Phoon, Hight and Leroueil, v. 3, pp. 2049-2100.

Eide, O. \& Andresen, A. (1977) Exploration, sampling and in-situ testing of soft clay. State-of-the-art report. Proc. Conference on Geotechnical Aspects of Soft Clays, Bangkok.

Francisco, G.M. (2004) Time Effect on Piles in Soft Clay. D.Sc. Thesis, COPPE, Federal University of Rio de Janeiro, Rio de Janeiro (in Portuguese).

Germaine, J.T. (2003) Personal Communication to Ladd and DeGroot (2003).

Henriques Jr., P.R.D.; Porto, E.C.; Medeiros Jr., C.J.; Foppa, D.; Costa, R.G.B.; Fernandes, J.V.V.; Danziger, F.A.B.; Jannuzzi, G.M.F.; Guimarães, G.V.M. \& Silva Jr., S.P. (2010) The development of the torpedo-piezocone: Purpose, challenges and initial test results. Proceedings (CD) of the XV Brazilian Conference on Soil Mechanics and Geotechnical Engineering, Gramado (in Portuguese).

Hight, D.W.; Boese, R.; Butcher, A.P.; Clayton, C.R.I. \& Smith, P.R. (1992) Disturbance of Bothkennar clay prior to laboratory testing. Géotechnique, v. 42:2, p. 199-217.

Hight, D.W . \& Leroueil, S. (2003) Characterisation of Soils for Engineering Purposes. Characterisation and Engineering Properties of Natural Soils, Balkema, v. 1, pp. 255-360.

Hvorslev, M.J. (1949) Subsurface Exploration and Sampling of Soils for Civil Engineering Purposes. The Waterways Experiment Station, Corps of Engineers, U.S. Army, Vicksburg, Miss, $521 \mathrm{p}$.

Jannuzzi, G.M.F. (2009) The Characterisation of Sarapuí II Soft Clay Site by In-Situ Testing. M.Sc. Thesis, COPPE, Federal University of Rio de Janeiro, Rio de Janeiro (in Portuguese).

Jannuzzi, G.M.F. (2013) Innovative and Traditional Methods to Characterise the Sarapuí II Soft Clay. Ph.D. Thesis, COPPE, Federal University of Rio de Janeiro, Rio de Janeiro (in Portuguese).

Jannuzzi, G.M.F.; Danziger, F.A.B.; Guimarães, G.V.M.; Silva Junior, S.P.; Henriques Jr, P.R.D.; Porto, E.C.; Medeiros Jr., C.J.; Foppa, D.; Costa, R.G.B. \& Fernandes, J.V.V. (2010) Initial onshore test results with the torpedo-piezocone at Sarapuí II test site. Proceedings (CD) of the XV Brazilian Conference on Soil Me- chanics and Geotechnical Engineering, Gramado (in Portuguese).

Jannuzzi, G.M.F.; Danziger, F.A.B.; Martins, I.S.M. \& Guimarães, G.V.M. (2012) The ability of in situ tests to detect the soil region affected by an embankment on soft clay. Proc., IV International Conference on Soil Characterization, ISC'4, Porto de Galinhas, v. 1, pp. 515-521.

Kallstenius, T. (1963) Studies on clay samples taken with standard piston sampler. Proc. Royal Swedish Geotechnical Institute, v. 21. pp 210.

Lacerda, W.A.; Costa Filho, L.M.; Coutinho, R.Q. \& Duarte, E.R. (1977) Consolidation characteristics of Rio de Janeiro soft clay. Proc., Conference on Geotechnical Aspects of Soft Clays, Bangkok, pp. 231-243.

Ladd, C. \& DeGroot, D. (2003) Recommended practice for soft ground site characterization: Arthur Casagrande Lecture. Proc., 12th Panamerican Conference on Soil Mechanics and Geotechnical Engineering, Boston, v. 1, pp. 3-57.

Landon, M.M. (2004) Field Quantification of Sample Disturbance of a Marine Clay Using Bender Elements. M.Sc. Thesis, University of Massachusetts, Amherst, MA.

La Rochelle, P.; Sarrailh, J.; Tavenas, F.; Roy, M. \& Leroueil, S. (1981) Causes of sampling disturbance and design of a new sampler for sensitive soil. Canadian Geotechnical Journal v. 18:1, p. 52-66.

Lefebvre, G. \& Poulin, C. (1979) A new method of sampling in sensitive clay. Canadian Geotechnical Journal, v. $16: 1$, p. $226-233$.

Lunne, T. \& Long, M. (2006) Review of long seabed samplers and criteria for new sampler design. Marine Geology, v. 226:1-2, p. 145-165.

Lunne, T.; Berre, T.; Andersen, K.H.; Strandvik, S. \& Sjursen, M. (2006) Effects of sample disturbance and consolidation procedures on measured shear strength of soft marine Norwegian clays. Canadian Geotechnical Journal, v. 43:7, p. 726-750.

Lunne, T.; Berre, T. \& Strandvik, S. (1997) Sample disturbance effects in soft low plastic Norwegian clay. Proc. Symp. on Recent Developments in Soil and Pavement Mechanics, Rio de Janeiro, pp. 81-102.

NBR 9820 (1997) Undisturbed sampling of soft soils - Procedure. Brazilian Standard (in Portuguese).

Oliveira, J.T.R. (2002) The Influence of Sample Quality on the Stress-Strain-Strength Behaviour of Soft Clays. Ph.D. Thesis, COPPE, Federal University of Rio de Janeiro, Rio de Janeiro.

Ortigão, J.A.R.; Werneck, M.L.G. \& Lacerda, W.A. (1983) Embankment failure on clay near Rio de Janeiro. Journal of the Geotechnical Engineering Division, ASCE, v. $109: 11$, p. $1460-1479$.

Porto, E.C.; Medeiros Jr., C.J.; Henriques Jr., P.R.D.; Foppa, D.; Ferreira, A.C.P.; Costa, R.G.B.; Fernandes, 
J.V.V.; Danziger, F.A.B.; Jannuzzi, G.M.F.; Guimarães, G.V.M.; Silva Jr., S.P. \& Alves, A.M.L. (2010) The development of the torpedo-piezocone. Proc. of the 29th International Conference on Ocean, Offshore and Arctic Engineering, OMAE 2010, American Society of Mechanical Engineers, New York.

Schmertmann, J. (1953) The undisturbed consolidation behavior of clay. Transactions ASCE, v. 120, pp. 12011227.

Tanaka, H. \& Nishida, K. (2007) Suction and shear wave velocity measurements for assessing sample quality.
Studia Geotechnica et Mecanica, v. XXIX:1-2, p. 163175.

Tanaka, H. \& Tanaka, M. (1999) Key factors governing sample quality. In: Tsuchida, Nakase (Eds.), Characterization of Soft Marine Clays. Balkema, pp. 57-81.

Werneck, M.L.G.; Costa Filho, L.M. \& França, H. (1977) In-situ permeability and hydraulic fracture tests in Guanabara bay clay. Proc. Conference on Geotechnical Aspects of Soft Clays, Bangkok, pp. 399-416. 


\title{
Remediation Techniques Applied in Residual Clayey Soil (Oxisol) Contaminated by Diesel and Biodiesel
}

\author{
L.R.R. Meneghetti, A. Thomé, F. Schnaid, L.M. Colla
}

\begin{abstract}
Biodegradation in residual basaltic soil contaminated by diesel fuel and biodiesel was assessed by three different techniques comprising natural attenuation, bioaugmentation, and bioventing. The soil was described in terms of its physicochemical and microbiological characteristics, showing favorable bioremediation conditions. Natural attenuation was monitored throughout the experiment. Bioaugmentation was performed using bacteria pre-selected from the soil at the concentration of $\sim 3.0 \times 10^{6} \mathrm{CFU} \mathrm{mL}^{-1}$. In the bioventing process, the soil was aerated during a period of $4 \mathrm{~h}$ a day at a pressure of $280 \mathrm{kPa}$. Bioremediation was assessed by counting the colony forming units (CFU g ${ }^{-1}$ of soil) and by degradation of contaminants using gas chromatography for 120 days. The highest microbial density was observed at 30 days in natural attenuation and at 60 days in bioaugmentation and bioventing. Biodiesel-contaminated soils had the largest microbial activity and highest degradation of carbon chains. At 120 days, bioaugmentation was the most efficient bioremediation technique, with the largest biodegradation rate for the light fraction of diesel (78.5\%) and for biodiesel esters $(98.6 \%)$. Bioventing was more efficient than natural attenuation for both contaminants, indicating the presence of aerobic bacteria at the analyzed soil depth.
\end{abstract}

Keywords: bioremediation, microorganisms, contaminants, aeration, residual soil.

\section{Introduction}

The contamination of soils and groundwater by petroleum hydrocarbons has grown in recent decades, especially because of the high frequency of contamination episodes and of the impacts of these episodes on the environment. Even though large accidental oil spills are often reported in the media, it is estimated that the major source of contamination by diesel fuel is related to small fuel leaks in containers, to mechanical or human error during unloading operations, or even to accidents during the transportation of this chemical.

According to Wolicka et al. (2009), the risk posed to the environment depends on the characteristics of the contaminated area (surface and/or depth) and on the chemical composition of petroleum hydrocarbons. In the case of fuel leaks into the soil, a wide range of physicochemical and biological processes are indicated for remediation of these hydrocarbons. Physicochemical processes such as air injection, soil vapor extraction, vapor removal and bioremediation are some of the remediation processes used in current practice. (Sharma \& Reddy, 2004).

Bioremediation processes have become recognized as alternatives for the treatment of soils contaminated by organic substances and have been preferred as they are based on natural and relatively simple methods that are less aggressive and more appropriate for the maintenance of ecological balance, aside from their low cost compared to other remediation processes (Bento et al., 2005, Mathew et al., 2006).

The bioremediation of organic pollutants by biodegradation is based on the capacity of microbial populations to modify or decompose pollutants. Biodegradation occurs by the action of soil microorganisms (natural attenuation) or inoculation of contaminated soil with bacteria (bioaugmentation), under natural process or stimulated by nutrients such as nitrogen and phosphorus (biostimulation) or by oxygen (bioventing) (Troquest et al., 2003).

The soil natural microbiological activity or the inoculated microorganisms are used in bioremediation processes to reduce the concentration and/or toxicity of different pollutants, including petroleum hydrocarbons (Alexander, 1994; Rajashekara Murthy et al., 2010; Castro-Gutiérrez et al., 2012; Lalevic et al., 2012). The major microorganisms that potentially degrade hydrocarbons in the soil include the genera Nocardia, Pseudomonas, Acinetobacter, Flavobacterium, Micrococcus, Arthrobacter, Corynebacterium, Achromobacter, Rhodococcus, Alcaligenes, Mycobacterium, Bacillus, Aspergillus, Mucor, Fusarium, Penicillium,

L.R.R. Meneghetti, MSc., Researcher, Graduate Program in Civil and Environmental Engineering, University of Passo Fundo, BR285, Bairro São José, Caixa Postal 611 99001-970 Passo Fundo, RS, Brazil. e-mail: lilianerebechi@yahoo.com.br.

A. Thomé, PhD., Professor, Graduate Program in Civil and Environmental Engineering, University of Passo Fundo, BR285, Bairro São José, $99001-970$ Passo Fundo, RS, Brazil.e-mail: thome@upf.br.

Fernado Schnaid, PhD., Professor, Graduate Program in Civil Engineering, Federal University of Rio Grande do Sul, Av. Osvaldo Aranha 99, 3 Andar, 90035190 Porto Alegre, RS, Brazil. e-mail: fernando@ufrgs.br.

L.M. Colla, PhD., Professor, Graduate Program in Civil and Environmental Engineering, University of Passo Fundo, BR 285, Bairro São José, 99001-970 Passo Fundo, RS, Brazil. e-mail: lmcolla@upf.br.

Submitted on April 8, 2013; Final Acceptance on August 2, 2013; Discussion open until April 30, 2014. 
Rhodotorula, Candida and Sporobolomyces, as reported by Leahy \& Colwell, 1990; Bento et al., 2003; Alvarez \& Illman, 2006; Sørensen et al., 2011.

Several studies have been recently carried out on bioremediation of soils contaminated by biodiesel and by diesel (Trindade, 2002; Bento et al., 2005; Byun et al., 2005; Hwang et al., 2006; Mariano, 2006; Wolicka et al., 2009; Bücker et al., 2011; Sørensen et al., 2011; Moliterni et al., 2012). However, little is known about the biodegradation potential of these contaminants in residual soil (Oxisol). This kind of soil is very common in different parts of the world and it is located mainly on developing countries.

The aim of the present study was to assess the biodegradation potential of a residual clayey soil (Oxisol) contaminated by diesel and biodiesel oil using three bioremediation processes: natural attenuation, bioaugmentation, and bioventing.

\section{Materials and Methods}

The experiments were undertaken ex situ using a residual clayey soil (oxisol) for addition of contaminants. Undisturbed soil samples were obtained at a depth of $1.2 \mathrm{~m}$, from B horizon. The physicochemical characteristics of the soil are shown in Table 1 . With respect to particle sizes, the residual soil contains $70 \%$ clay, $6 \%$ silt and $24 \%$ fine sand (ASTM D422). Although the soil presents high clay amount in its composition, it can be observed in Table 1 that the soil has high hydraulic conductivity. The oxisol has well-structured aggregates and are composed of mixture of kaolinite and Fe oxide (hematite). This makes the soil composed with stable aggregates and they are responsible for high infiltration and, as consequence, high hydraulic conductivity.

For all tests undisturbed soil samples were molded into cylindrical shape, $100 \mathrm{~mm}$ high and $75 \mathrm{~mm}$ in diameter and were placed in bioreactors made of screw-capped polyvinyl chloride (PVC) tubes with $100 \mathrm{~mm}$ in diameter and $200 \mathrm{~mm}$ in length. The samples were inserted inside the PVC tube and the lateral space was filled with commercial gypsum slurry, thus furthering a state of containment after its cure. This was necessary to avoid preferential flow between soil and the tube wall, since the cured gypsum has hydraulic conductivity a hundred times lower than soil used in this work.

Natural soil samples were contaminated with diesel fuel (of type C, sold at gas stations in Brazil) and with animal derived biodiesel (B100). The contaminants were autoclaved to clean all microorganisms that could be present in oil and only allow soil microorganism in the biodegradation process. The contaminant was poured on the samples in an amount equal to the void volume of the sample. The percentage of absorbed contaminant was about $4 \%$ in relation to the dry soil mass for all samples. The contaminants physicochemical characteristics are specified in $\mathrm{Ta}-$ ble 2 .

The density of soil microbial communities was evaluated using culture media in plates by spread plate technique. Although this method has limitations about the growth of microorganisms in culture medium (as it is estimated that $1 \%$ of the microorganisms are cultivable), this form of indirect evaluation is most adopted as a method for evaluation of the occurrence, density and diversity of microorganism in soil.

First, the soil sample was homogenized for 2 min with sterile distilled water using 1:9 ratio. Later, dilutions up to $10^{-5}$ were carried out and $100 \mu \mathrm{L}$ of each dilution was added to the surface of Petri dishes containing Plate Count Agar (PCA). The dishes were incubated at $30^{\circ} \mathrm{C}$ for $48 \mathrm{~h}$ and microbial growth was determined by counting the colony forming units (CFU), and the results were expressed as CFU g ${ }^{-1}$ of soil.

Thereafter, the different colonies were transferred to culture media for purification and isolated growth and later identification by physiological and biochemical tests (Cappuccino \& Sherman, 1996; Quinn et al., 2002; Tortora, et al., 2008).

The resistance of the isolated bacteria to hydrocarbons was tested using the Bushnell-Hass Broth (BH), con-

Table 1 - Physicochemical characteristics of natural soil used in bioremediation.

\begin{tabular}{lccc}
\hline Parameters/Soil & Values & Parameters/Soil & Values \\
\hline Natural moisture $(\%)$ & 34 & $\mathrm{H}_{2} \mathrm{O} \mathrm{pH}$ & 5.4 \\
Specific Gravity $-\mathrm{G}$ & 2.7 & $\mathrm{P}\left(\mathrm{mg} / \mathrm{dm}^{3}\right)$ & 4 \\
Liquid Limit $\left(\omega_{\mathrm{L}}\right)(\%)$ & 53 & $\mathrm{~K}\left(\mathrm{mg} / \mathrm{dm}^{3}\right)$ & 28 \\
Plastic Limit $\left(\omega_{\mathrm{p}}\right)(\%)$ & 42 & $\mathrm{H}+\mathrm{Al}\left(\mathrm{cmol}_{\mathrm{c}} / \mathrm{dm}^{3}\right)$ & 6.2 \\
Plasticity Index $(\mathrm{PI})(\%)$ & 11 & $\mathrm{CEC}\left(\mathrm{cmol}_{\mathrm{c}} / \mathrm{dm}^{3}\right)$ & 8.6 \\
Saturation rate $(\%)$ & 74.2 & Saturation $-\mathrm{Bases}(\%)$ & 28 \\
Porosity $(\%)$ & 55 & Saturation $-\mathrm{Al}(\%)$ & 50 \\
Void ratio & 1.24 & Saturation $-\mathrm{K}(\%)$ & 0.8 \\
Organic Matter $(\%)$ & $<0.8$ & Hydraulic Conductivity $(\mathrm{m} / \mathrm{s})$ & $1.4 \times 10^{-5}$ \\
\hline
\end{tabular}


Table 2 - Physicochemical characteristics of conventional diesel oil and chemical characteristics of animal-derived biodiesel.

\begin{tabular}{lccc}
\hline Characteristics * & Diesel (\%) & Characteristics** & Biodiesel (\%) \\
\hline Sulfur $(\%)$ & 0.3 & Myristic acid (14:0) & 5.03 \\
Carbon $(\%)$ & 86 & Palmitic acid (16:0) & 29.09 \\
Hydrogen $(\%)$ & 13.4 & Palmitoleic acid (16:1) & 3.22 \\
Oxygen $(\%)$ & 0 & Stearic acid $(18: 0)$ & 25.33 \\
Aromatics $(\% \mathrm{v} / \mathrm{v})$ & 31.5 & Oleic acid $(18: 1)$ & 35.85 \\
Viscosity at $40{ }^{\circ} \mathrm{C}(\mathrm{cSt})$ & 2.5 to 5.5 & Linoleic acid $(18: 2)$ & 1.48 \\
Cetane number $(\mathrm{CN})$ & 42 & Saturated & 59.45 \\
Density at $15{ }^{\circ} \mathrm{C}\left(\mathrm{kg} / \mathrm{m}^{3}\right)$ & 0.849 & Unsaturated & 40.55 \\
Cloud point ${ }^{\circ} \mathrm{C}$ & 1 & Cetane number $(\mathrm{CN})$ & 69 \\
Calorific value $(\mathrm{MJ} / \mathrm{kg})$ & 42.30 & Viscosity at $40{ }^{\circ} \mathrm{C}(\mathrm{cSt})$ & 5.14 \\
Moisture $(\mathrm{ppm})$ & 58 & Cloud point ${ }^{\circ} \mathrm{C}$ & $8-10$ \\
& & Calorific value $(\mathrm{MJ} / \mathrm{kg})$ & 39.33 \\
& & Moisture $(\mathrm{ppm})$ & 1390 \\
\hline
\end{tabular}

Source: * NPA (2010), ** Schuller (2007).

taining $1 \%$ of diesel and tetrazolium chloride (TTC) as indicator according to the method proposed by Braddock \& Catterall (1999) referenced by Bento et al. (2005) and Cerqueira \& Costa (2009).

The inocula were incubated at $30{ }^{\circ} \mathrm{C}$ and $150 \mathrm{rpm}$ for 14 days. Microbial growth was qualitatively determined by violet color development (indicating reduction of the indicator via respiration).

The inoculum used for bioaugmentation was prepared with the isolated microorganisms that were able to degrade diesel fuel. An aliquot of $1,000 \mu \mathrm{L}$ of each bacterial suspension was used in $50 \mathrm{~mL}$ of liquid $\mathrm{BH}$ medium, kept under orbital agitation at $120 \mathrm{rpm}$ and $28{ }^{\circ} \mathrm{C}$. After $24 \mathrm{~h}$ of incubation, successive dilutions in peptone water at $0.1 \%$ were performed and Petri dishes containing PCA were inoculated for the count of microorganisms in the inoculum. The bioaugmentation inoculum had the concentration of approximately $3.0 \times 10^{6} \mathrm{CFU} \mathrm{mL}^{-1}$ of the microbial consortium. Afterwards, $1,000 \mu \mathrm{L}$ of the inoculum from each isolate was slowly added (poured) on the 500gram soil samples in each bioaugmentation treatment.

An aeration device was developed for the bioventing process (Fig. 1). It is composed by an air compressor and a water filter (this was used to avoid the air contamination by the compressor oil). This equipment allowed air to flow upwards in samples. This air was used as a source of biostimulation for microbial growth. It was used a daily continuum ventilation for four hours at pressure of $280 \mathrm{kPa}$.

Bioremediation trials were carried out in triplicates, and soil samples were assessed at predefined times, namely at 30, 60, 90 and 120 days, as outlined in Table 3.

Moisture and $\mathrm{pH}$ were measured accordingly. Moisture losses as high as $8.75 \%$ were observed during bioventing treatments (compared to moisture at baseline). With regard to $\mathrm{pH}$, slight acidification was observed in all experiments, but the largest variation occurred in treatment bioventing + biodiesel of the bioventing procedure, in which $\mathrm{pH}$ dropped from 5.4 to 4.4 .

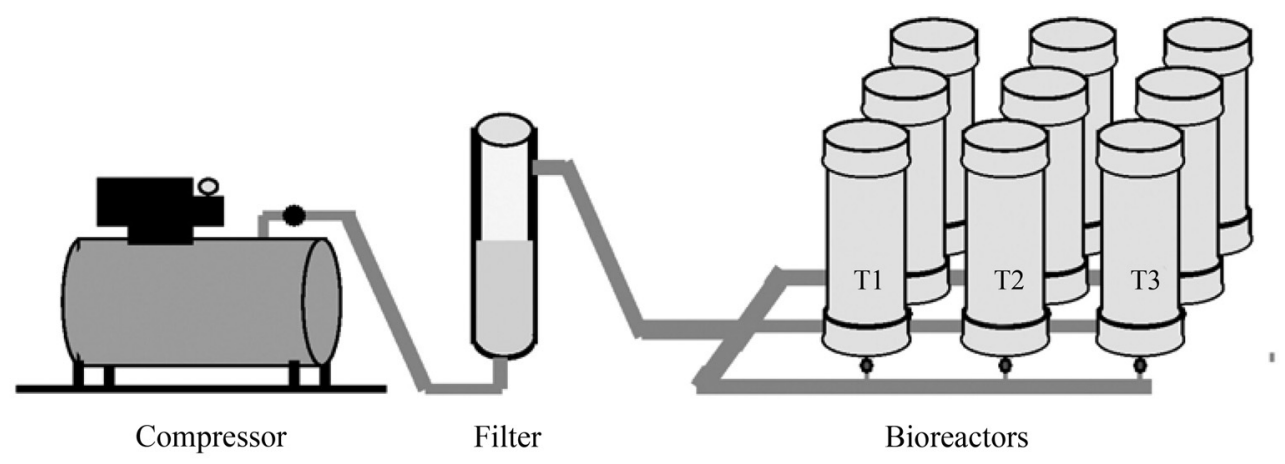

Figure 1 - Aeration device layout. 
Table 3 - Treatments used in the bioremediation experiment.

\begin{tabular}{lcc}
\hline Treatments & Contaminants & Bioremediation procedures \\
\hline Natural Attenuation (T1) & No contaminant & Control \\
Natural Attenuation (T2) & Diesel & Natural Attenuation \\
Natural Attenuation (T3) & Biodiesel & Natural Attenuation \\
Bioaugmentation (T4) & No contaminant & Control* $^{*}$ \\
Bioaugmentation (T5) & Diesel & Bioaugmentation * \\
Bioaugmentation (T6) & Biodiesel & Bioaugmentation * \\
Bioventing (T7) & No contaminant & Control** \\
Bioventing (T8) & Diesel & Bioventing** \\
Bioventing (T9) & Biodiesel & Bioventing** \\
\hline
\end{tabular}

*Bacterial inoculum $\left(\sim 3.0 \times 10^{6} \mathrm{CFU} \mathrm{mL} \mathrm{mL}^{-1}\right)$.**Period: four daily hours at a pressure of $280 \mathrm{kPa}$.

The Soxhlet method (USEPA, 1996) was used for the extraction of soil contaminants. The contaminants were quantified by a Varian Gas Chromatograph (model 3400) equipped with a flame ionization detector. Hydrogen was used as carrier gas at a flow rate of $2 \mathrm{~mL}$. $\mathrm{min}^{-1}$. Injector and detector temperatures were $250{ }^{\circ} \mathrm{C}$ and $300{ }^{\circ} \mathrm{C}$, respectively. A PE $=$ WAX capillary column $(30 \mathrm{~m} \mathrm{x} 0.25 \mathrm{~mm}$ x $0.25 \mu \mathrm{m}$ ) was used for determination of hydrocarbons, with an initial oven temperature of $35^{\circ} \mathrm{C}$, increasing from $5{ }^{\circ} \mathrm{C}$ $\min ^{-1}$ to $245^{\circ} \mathrm{C}$, and remaining at the latter temperature for $20 \mathrm{~min}$. The CP Sil 88 capillary column (50 m x $0.25 \mathrm{~m} \mathrm{x}$ $20 \mu \mathrm{m})$ was used for determination of fatty acids, with an initial temperature of $140{ }^{\circ} \mathrm{C}$, increasing $1{ }^{\circ} \mathrm{C} \mathrm{min}$ until $^{-1}$ reaching $185^{\circ} \mathrm{C}$. Hydrocarbons and fatty acids were identified by comparing retention times with specific standards quantified by normalization of the areas.

The experiments were conducted independently in triplicates. The count of microorganisms in $\mathrm{CFU} \mathrm{g} \mathrm{g}^{-1}$ of soil was normalized by logarithmic transformation and assessed by analysis of variance (ANOVA) and Tukey's test at $5 \%$ for comparison of the means.

\section{Results and Discussion}

The microorganisms isolated from the natural soil (used in bioaugmentation) were identified as bacteria of the species Bacillus circulans and Pseudomonas aeroginosa. These bacteria are referenced in the literature as organic pollutant degraders (Bento \& Gaylard, 2001; Alvarez \& Illman, 2006; Labbé et al., 2007).

The population density of microorganisms is influenced by bioremediation treatments and should be estimated in order to determine the relationship between microbial activity and the degradation rate. The Table 4 shows the means for the total number of microorganisms (CFU/g soil) and significant differences with a 95\% confidence interval (Tukey's test) for the bioremediation of natural soils, contaminated by diesel and biodiesel, through natural attenuation, bioaugmentation and bioventing. Figure 2 shows the results for microbial count ( $\left.\log \mathrm{CFU} \mathrm{g}^{-1}\right)$ of soils, comparing the same contaminant under effect of the three different treatments.

It can be observed in Fig. 2a that microbial count in the control experiment decreased over time, being statistically significant compared to the initial time after 60 days $(\mathrm{p}=0.037)$. On the other hand, soils contaminated by diesel and biodiesel and submitted to natural attenuation maintained the concentration of microorganisms when compared to initial time ( $\mathrm{p}>0.05)$ all through the bioremediation process for treatment $\mathrm{T} 2$ (diesel used as contaminant) and up to 90 days for treatment T3 (biodiesel used as

Table 4 - Microbial count in different treatments and the statistical differences concerning the interaction between time and treatment.

\begin{tabular}{|c|c|c|c|c|c|c|c|c|c|}
\hline \multirow[t]{2}{*}{ Time (d) } & \multicolumn{9}{|c|}{ Total plate count ( $\log \mathrm{CFU} \mathrm{g}{ }^{-1}$ of soil) } \\
\hline & $\mathrm{T} 1$ & $\mathrm{~T} 2$ & T3 & $\mathrm{T} 4$ & T5 & T6 & $\mathrm{T} 7$ & $\mathrm{~T} 8$ & T9 \\
\hline 0 & $3.28^{\mathrm{Ab}}$ & $3.28^{\mathrm{Ab}}$ & $3.28^{\mathrm{Ab}}$ & $3.89^{\mathrm{Aa}}$ & $3.89^{\mathrm{Aa}}$ & $3.89^{\mathrm{Aa}}$ & $3.28^{\mathrm{Ab}}$ & $3.28^{\mathrm{Ab}}$ & $3.28^{\mathrm{Ab}}$ \\
\hline 30 & $2.73^{\mathrm{ABb}}$ & $2.94^{\mathrm{Ab}}$ & $3.30^{\mathrm{Ab}}$ & $3.67^{\mathrm{Ba}}$ & $2.97^{\mathrm{Bb}}$ & $2.74^{\mathrm{Cb}}$ & $2.84^{\mathrm{Bb}}$ & $2.93^{\mathrm{Ab}}$ & $2.89^{\mathrm{Bb}}$ \\
\hline 60 & $2.55^{\mathrm{Bcd}}$ & $2.93^{\mathrm{Abcd}}$ & $3.07^{\text {Aabd }}$ & $3.55^{\mathrm{BCa}}$ & $3.19^{\mathrm{Bab}}$ & $3.61^{\mathrm{Ba}}$ & $3.64^{\mathrm{Aa}}$ & $2.34^{\mathrm{Bc}}$ & $3.23^{\text {Aab }}$ \\
\hline 90 & $2.21^{\mathrm{Bc}}$ & $2.82^{\text {Aab }}$ & $2.88^{\mathrm{ABab}}$ & $3.23^{\mathrm{Ca}}$ & $3.07^{\mathrm{Bab}}$ & $2.79^{\mathrm{Cab}}$ & $2.58^{\mathrm{cbc}}$ & $2.19^{\mathrm{Bc}}$ & $2.57^{\mathrm{Cbc}}$ \\
\hline 120 & $2.39^{\mathrm{Ba}}$ & $2.78^{\mathrm{Aa}}$ & $2.41^{\mathrm{Ba}}$ & $2.55^{\mathrm{Da}}$ & $2.79^{\mathrm{Ba}}$ & $2.38^{\mathrm{Da}}$ & $2.49^{\mathrm{Ca}}$ & $2.13^{\mathrm{Ba}}$ & $2.58^{\mathrm{BCa}}$ \\
\hline
\end{tabular}

Values with the same lowercase letter superscript, in each row, are not significantly different at the 95\% confidence level, based on Tukey's range test. Values with the same uppercase letter superscript, in each column, are not significantly different at the $95 \%$ confidence level, based on Tukey's range test. 
contaminant). Although treatment of natural attenuation did not differs significantly over time, the presence of contaminant contributed to maintain the concentration of autochthonous microorganisms in the soil during the study period, to be sources of carbon and energy to the metabolism, determinant factor for the bioremediation.

Bioaugmentation in treatments T4, T5 and T6 (Fig. 2b) revealed that the microbial count decreased at 30 days of bioremediation compared to the initial time (comparison by the Tukey's test denoted by capital letters in Table 4, p < 0.05). Nonetheless, comparing the microbial count at 30 days of treatment for the three experiments indicates that the addition of contaminant (T5 and T6) caused microbial concentration to fall more sharply than that of T4 (3.67 significantly higher than 2.97 and 2.74 at a significance level lower than 0.05 , compared to treatments T4, T5 and T6 at 30 days, small letters on Tukey's test, Table 4). The inoculated bacteria, although they were in the growth stage, needed time to adapt to the contaminated medium.
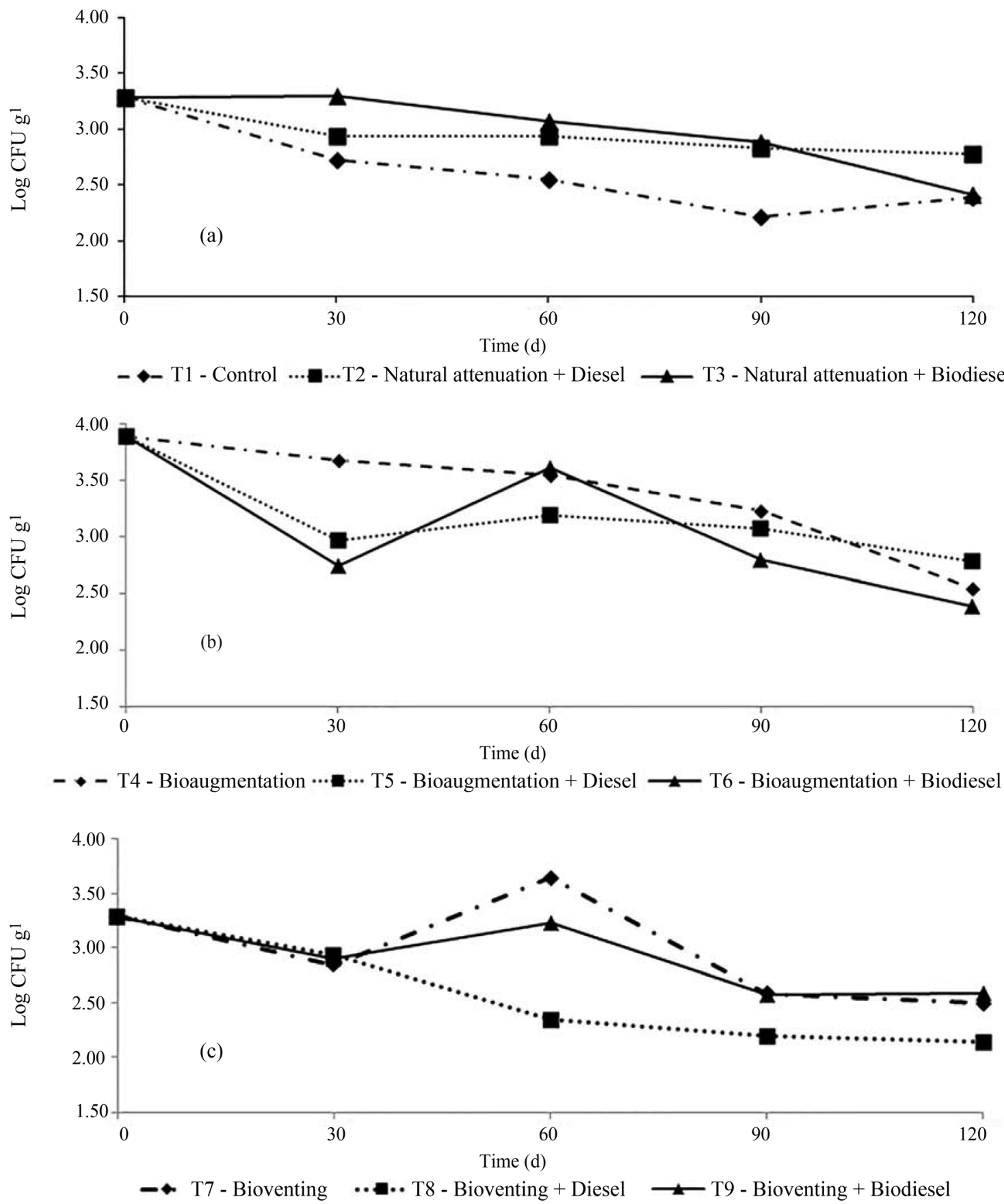

Figure 2 - Microbial density (CFU/g soil) of treatments over time. (a) Natural Attenuation, (b) Bioaugmentation and (c) Bioventing. 
In bioremediation trials in which bioventing was used (Fig. 2c), there was a significant reduction $(\mathrm{p}<0.05)$ in the concentration of microorganisms in the soil compared to the results obtained for treatments T7 (bioventing of contaminant-free soil) and T9 (bioventing of biodiesel-contaminated soil) at 30 days and at baseline. Even though microbial count decreased in T8 (bioventing of dieselcontaminated soil) relative to baseline values, no significant difference was found between these counts $(p>0.05)$. However, after 30 days of bioremediation, there was a significant reduction in microbial concentration in dieselcontaminated soils and in biovented in a period of up to 120 days, when counts are compared with those obtained in experiments T7 and T9. This may have been caused by a toxic effect on the metabolites produced during diesel bioremediation after 30 days of treatment (T8).

By comparing the control experiment in the natural attenuation treatment (T1) with the control experiment in the bioventing treatment (T7), microbial activity continues to increase up to 60 days under aerobic conditions whereas this activity begins to decline in the natural soil at 30 days. This increase in population density in treatment T7 indicates the presence of facultative aerobic/anaerobic microorganisms at this depth. These results are in agreement with those obtained by Österreicher-Cunha et al. (2004). They demonstrated that the natural soil when biostimulated with air (control + bioventing) had larger population density than the untreated natural soil (control), showing the presence of aerobic microorganisms. After 40 days, microbial population increased in all of the other treatments, confirming that microorganisms need some time to adapt to the bioremediation conditions imposed on the medium.

The rate of diesel and biodiesel degradation obtained by gas chromatography at the end of the experiment is shown in Fig. 3. The highest biodiesel biodegradation rates occurred in treatments T6 (bioaugmentation) and T9 (bioventing), amounting to $96.8 \%$ and $90.6 \%$, respectively, followed by natural attenuation (T3), with a rate of $60.6 \%$. Biodiesel biodegradation was easier than that of diesel in treatments T2, T5 and T9, as a consequence of the different chemical composition of contaminants. The results ob-

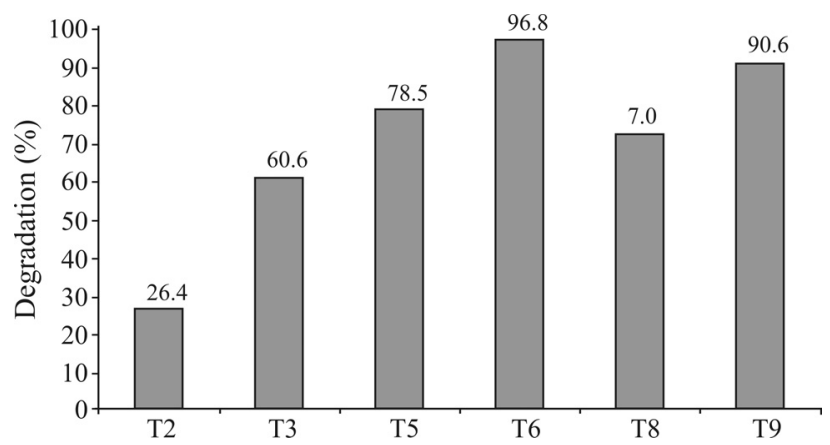

Figure 3 - Degradation rate for diesel oil and biodiesel in bioremediation treatments at 120 days. tained in this work are in agreement with those found by Cyplik et al. (2011) and Lapinskiené et al. (2006). They found that the biodegradation caused by a microbial consortium relies on the type of fuel used and on the available aerobic conditions, and thus biodiesel degradation is faster than that of diesel under aerobic conditions. Biodiesel is much more biodegradable than fossil diesel due to its chemical features (Zhang et al., 1998).

Figures 4 and 5 show the degradation rate of carbon chains for biodiesel and diesel, respectively. Biodiesel yielded 99\% degradation of palmitic (C16:0), palmitoleic (C16:1), stearic (C18:0) and oleic (C18:1) acids in bioaugmentation; 97\% for palmitic (C16:0) and oleic (C18:1) acids in bioventing, and 68\% for oleic acid (C18:1) in natural attenuation.

The highest degradation rate for the light fraction (C12-C23) of TPH found in diesel (Fig. 4) was observed in bioaugmentation $(78.5 \%)$, followed by bioventing $(72 \%)$ and natural attenuation (26\%). These findings are similar to those obtained by Bento et al. (2005) for bioremediation. These authors observed that bioaugmentation (63-84\%) was more efficient in diesel degradation than were biostimulation $(72 \%)$ and natural attenuation $(47 \%)$. Also, according to Bento et al. (2003), bioaugmentation with

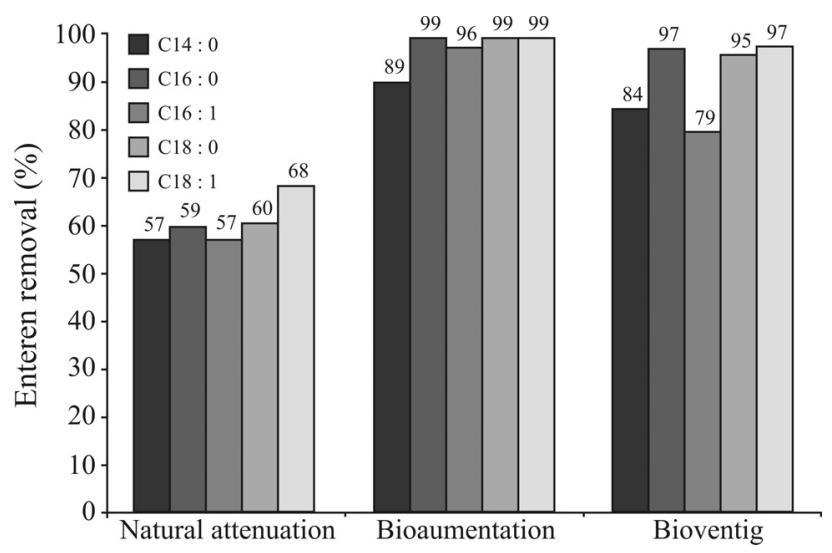

Figure 4 - Degradation rate for biodiesel esters.

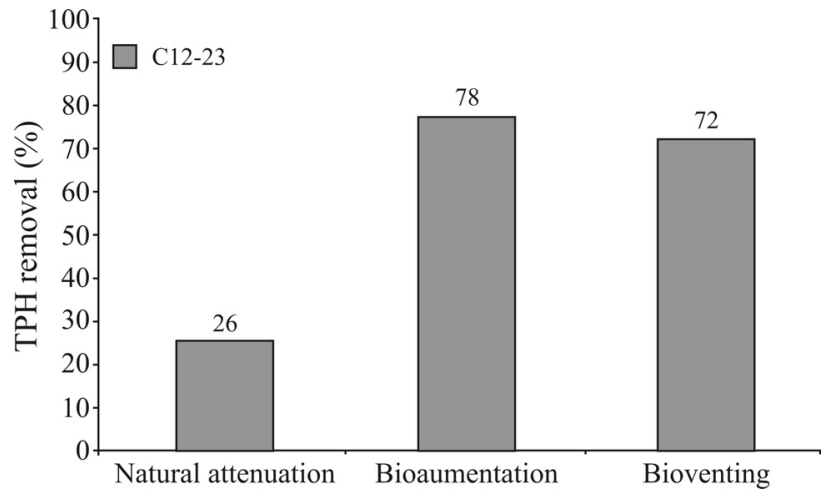

Figure 5 - Degradation rate for the light fraction of diesel (C12-23). 
inocula from bacteria pre-selected from a contaminated medium provides higher degradation, as they recognize diesel oil hydrocarbons more easily, using them as source of energy for their growth. Bioremediation studies conducted in laboratory by Capelli et al. (2001) also demonstrated a reduction of over $70 \%$ of TPH when inoculated by pre-selected bacteria.

Other bioremediation studies carried out by Sayara et al. (2011) and Kauppi et al. (2011) demonstrated that biostimulation with nutrients and oxygen is more efficient than bioaugmentation. Sayara et al., 2011 assessed the degradation of several aromatic polycyclic hydrocarbons (APHs) in the soil by applying bioaugmentation, biostimulation, and natural attenuation. After 30 days, analyses showed that the inoculum of fungus $T$. versicolor did not improve the degradation of APH significantly. However, biostimulation degraded $89 \%$ of APHs while natural attenuation degraded $29.5 \%$ (carried out by microorganisms of the indigenous soil).

As presented in Table 4, the 120 days of studied bioremediation techniques do not show statistical differences in the evaluation of microorganisms, however, it can be observed in Fig. 3, that there is a great difference in the percentage of degradation among the techniques, being the degradation of 26.4\% for T2 (Natural Attenuation + diesel), while the degradation for the technique T6 (Bioaugmentation + biodiesel) was $96.8 \%$.

\section{Conclusion}

This study assessed the biodegradation potential of a residual clayey soil (Oxisol) contaminated by diesel and biodiesel, comparing natural attenuation, bioaugmentation and bioventing processes, allowing to identify differences in contaminant degradation.

The highest degradation took place in the treatments of biodiesel-contaminated soil, compared to those contaminated by diesel, due to the chemical characteristics of contaminants.

Bioaugmentation was the bioremediation procedure with the best test results owing to the inoculum of microorganisms pre-selected from the residual soil, with $78.5 \%$ degradation of the light fraction of diesel (TPH) and 96.8\% degradation of fatty acid esters of biodiesel.

Bioventing yielded higher biodegradation rates than natural attenuation because of the presence of aerobic bacteria in the residual soil.

Microorganisms of the genera Bacillus circulans and Pseudomonas aeroginosa have shown to be efficient organic pollutant degraders in residual clayey soil (oxisols).

The inoculum of degrading microorganisms, associated with the addition of nutrients (oxygen, nitrogen, phosphorus and/or potassium) allows increasing the degradation of soil contaminants by reducing time and costs of remediation processes.

\section{Acknowledgments}

The authors wish to express their gratitude to the Brazilian Research Council (CNPq/MCT and CAPES/MEC) and Rio Grande do Sul State Research Foundation (FAPERGS) for their financial support.

\section{References}

Alexander, M. (1994) Biodegradation and Bioremediation. Academic Press, San Diego, 453 pp.

Alvarez, P.J.J. \& Illman, W.A. (2006) Bioremediation and Natural Attenuation: Process Fundamentals and Mathematical Models. John Wiley \& Sons, New Jersey, 612 pp.

Bento, F.M. \& Gaylarde, C.C. (2001) Microbial contamination of stored diesel oil: Studies in Brazil. International Biodeterioration and Biodegradation, v. 47, p. 107-112.

Bento, F.M.; Camargo, F.A.O.; Okeke, B. \& Frankenberger-Jr., W.T. (2003) Bioremediation of soil contaminated by diesel oil. Brazilian Journal of Microbiology, v. 34, p. 65-68.

Bento, F.M.; Camargo, F.A.O.; Okeke, B.C. \& Frankenberger, W.T. (2005) Comparative bioremediation of soils contaminated with diesel oil by natural attenuation, biostimulation and bioaugmentation. Bioresource Technology, v. 96, p. 1049-1055.

Braddock, J.F. \& Catterall, P.H. (1999) A simple method for enumerating gasoline- and diesel-degrading microorganisms. Bioremediation. Journal, v. 3, p. 81-84.

Bücker, F.; Santestevan, N.A.; Roesch, L.F.; Jacques, R.J.S.; Peralba, M.C.R.; Camargo, F.A.O. \& Bento, F.M. (2011) Impact of biodiesel on biodeterioration of stored Brazilian diesel oil. International Biodeterioration and Biodegradation, v. 65, p. 172-178.

Byun, I.-G.; Nam, H.-U.; Song, S.K.; Hwang, I-S.; Lee, T-H. \& Park, T.-J. (2005) Monitoring of bioventing process for diesel-contaminated soil by dehydrogenase activity, microbial counts and the ratio of n-alkane/isoprenoid. Korean Journal Chem. Eng., v. 22, p. 917-921.

Capelli, S.M.; Busalmen, J.P. \& Sanches, S.R. (2001) Hydrocarbon bioremediation of a mineral-base contaminated waste from crude oil extraction by indigenous bacteria. International Biodeterioration and Biodegradation, v. 47, p. 233-238.

Cappuccino, J.G. \& Sherman, N. (1996) Microbiology: A Laboratory Manual. The Benjamin/Cummings Publishing Company Inc., Menlo Park, California, pp. 441.

Castro-Gutiérrez, V.M.; Rodríguez-Rodríguez, C.E. \& Vargas-Azofeifa, I. (2012) Hydrocarbon degrading microflora in a tropical fuel-contaminated aquifer: Assessing the feasibility of PAH bioremediation. International Journal of Environmental Research, v. 6:1, p. 345-352. 
Cerqueira, V.S. \& Costa, J.A.V. (2009) Biodegradation of toluene and fish oil in contaminated soil using chemical and biological surfactants. New Chemical, v. 32, p. 394-400.

Cyplik, P.; Schmidt, M.; Szulc, A.; Marecik, R.; Lisiecki, P.; Heipieper, H.J.; Owsianiak, M.; Vainshtein, M. \& Chrzanowski, L. (2011) Relative quantitative PCR to assess bacterial community dynamics during biodegradation of diesel and biodiesel fuels under various aeration conditions. Bioresource Technology, v. 102, p. 4347-4352.

Kauppi, S.; Sinkkonen, A. \& Romantschuk, M. (2011) Enhancing bioremediation of diesel-fuel-contaminated soil in boreal climate: Comparison of biostimulation and bioaugmentation. International Biodeterioration and Biodegradation, v. 65, p. 359-368.

Labbé, D.; Margesin, R.; Schinner, F.; Whyte, L. \& Greer, C. (2007) Comparative phylogenetic analysis of microbial communities in pristine and hydrocarbon contaminated Alpine soils. FEMS Microbiology Ecology, v. 59, p. 466-475.

Lalevic, B.; Raicevic, V.; Kikovic, D.; Jovanovic, L.; Surlan-Momirovic, G.; Jovic, J.; Talaie, A.R. \& Morina, F. (2012) Biodegradation of MTBE by bacteria isolated from oil hydrocarbons-contaminated environments. International Journal of Environmental Research, v. 6:1, p. 81-86.

Lapinskiené, A.; Martinkus, P. \& Rébzdaite, V. (2006) Eco-toxicological studies of diesel and biodiesel fuels in aerated soil. Environmental Pollution, v. 142, p. 432-437.

Leahy, J.G. \& Colwell, R.R. (1990) Microbial degradation of hydrocarbons in the environment. Microbiol. Rev., v. 54, p. 305-315.

Mariano, A.P. (2006) Evaluation of the Potential for Bioremediation of Soils and Groundwater Contaminated Diesel. Dissertation, UNESP-Rio Claro, 147 pp (in Portuguese).

Mathew, M.; Tan, L.R.; Su, Q.; Yang, X.; Baxter, M. \& Senior, E. (2006) Bioremediation of $6 \%$ [w/w] dieselcontaminated mainland soil in Singapore: Comparison of different biostimulation and bioaugmentation treatments. Engineering Life Science, v. 6, p. 63-67.

Moliterni, E.; Rodriguez, L.; Fernández, F.J. \& Villaseñor, J. (2012) Feasibility of different bioremediation strategies for treatment of clayey and silty soils recently polluted with diesel hydrocarbons. Water Air Soil Pollut, v. 223, p. 2473-2482.

National Petroleum Agency (2010). Chemical composition of diesel. Retrieved in July, 4 2010. Avaliable at http//www.anp.gov.br (in Portuguese).

Österreicher-Cunha, P.; Vargas Jr., E.A.; Guimarães, J.R.D.; Campos, T.M.P., Nunes, C. M.F.; Costa, A.; Antunes, F. dos S.; Silva, M.I.P. \& Mano, D.M. (2004)
Evaluation of bioventing on a gasoline-ethanol contaminated undisturbed residual soil. Journal of Hazardous Materials, v. 110, p. 63-76.

Quinn, P.J.; Markey, B.K.; Carter, M.E.; Donnelly, W.J. \& Leonard, F.C. (2002) Veterinary Microbiology and Microbial Diseases. Blackwell Science Ltda, Ames, Iowa, 912 pp.

Rajashekara Murthy, H.M.; Thakur, M.S. \& Manonmani, H.K. (2010) Degradation of Technical grade hexachlorocyclohexane in soil slurry by a defined microbial consortium. International Journal of Environmental Research, v. 4:3, p. 471-478.

Sayara, T.; Borràs, E.; Caminal, G.; Sarrà, M. \& Sánchez, A. (2011) Bioremediation of PAHs-contaminated soil through composting: influence of bioaugmentation and biostimulation on contaminant biodegradation. International Biodeterioration and Biodegradation, v. 65, p. 859-865.

Schuller, A. (2007) Biodiesel production and quality control by HPLC. Retrieved Jan. 15. Avalible at http:// www.perkinelmer.com.br/home/seminarios/biodiesel (in Portuguese).

Sharma, H.D. \& Reddy, K.R. (2004) Geoenvironmental Engineering: Site Remediation, Waste Containment and Emerging Waste Management Technologies. John Wiley \& Sons, Inc. Hoboken, New Jersey, 968 pp.

Sørensen, G.; Pedersen, D.V.; Nørgaard, A.K.; Sørensen, K.B. \& Nygaard, S.D. (2011) Microbial growth studies in biodiesel blends. Bioresource Technology, v. 102, p. 5259-5264.

Tortora, G.J.; Funke, B.R. \& Case, C.L. (2008) Microbiology: An Introduction. 10th Edition. Benjamin Cummings, Menlo Park, California, 960 pp.

Trindade, P.V.O. (2002) Evaluation of Biostimulation and Bioaugmentation Techniques in the Process of Bioremediation of Soils Contaminated with Petroleum Hydrocarbons. Dissertation, Federal University of Rio de Janeiro. 127 pp (in Portuguese).

Troquest, J.; Larroche, C. \& Dussap, C.G. (2003) Evidence for the occurrence of an oxygen limitation during soil bioremediation by solid-state fermentation. Biochemical Engineering Journal, v. 13, p. 103-112.

USEPA - United States Environmental Protection Agency (1996) Method 3540c, Soxhlet extraction, 1996. Retrieved Feb 2, 2011 from www.epa.gov/sw-846/pdfs/3540c.pdf.

Wolicka, D.; Suszek, A.; Borkowski, A. \& Bielecka, A. (2009) Application of aerobic microorganisms in bioremediation in situ of soil contaminated by petroleum products. Bioresource Technology, v. 100, p. 32213227.

Zhang, X.; Peterson, C.; Reece, D.; Haws, R. \& Moller, G. (1998) Biodegradability of biodiesel in the aquatic environment. Trans. ASAE, v. 41, p. 1423-1430. 


\title{
Behavior of Clay-Tire Mixtures Subjected to Undrained Monotonic Loading
}

\author{
H. Soltani-Jigheh, V. Marefat, A. Ersizad
}

\begin{abstract}
Soil - tire mixtures have been recently used as construction materials in civil engineering projects. In this research, a number of undrained triaxial tests were carried out on the compacted clay-tire mixtures and their behaviors were compared with behavior of pure clays. The results of the tests indicate that adding more than about 20\%-30\% tire to the low plasticity clay doesn't reduce the shear strength in comparison with the associated values of pure clay. In the mixtures made of high plasticity clay, the shear strength decreases by increasing tire content. Moreover, friction angle and cohesion values vary with increasing tire-chips, which is completely dependent on the clay plasticity. The results also demonstrated that, for the mixtures of low plasticity clay, maximum excess pore water pressure occurs in the specimens with tire content of about $10 \%-20 \%$. For the mixtures consist of high plasticity clay, at low consolidation stress, the pore water pressure decreases slightly with an increase in tire content. At high consolidation stress, excess pore water pressure induced within these mixtures increases slightly with an increase in tire-chips content. Adding tire-chips to the clay also lead to increase deformability of mixtures considerably.
\end{abstract}

Keywords: clay-tire-chip mixtures, triaxial test, shear strength, pore water pressure.

\section{Introduction}

A large volume of waste tires is being generated every year and results in major environmental hazards worldwide. Rubber Manufacturer's Association (2013) estimates that about 296.7 million tires (5170.5 thousand tons) were generated in the USA in 2009 and the total percent of tires consumed in end-use markets reached approximately $84.9 \%$. It also estimates that about $12.6 \%$ of scrap tires have been disposed in the land at the end of 2009.

It has also been reported that about 20 million tires were produced in Iran 2005 and about 10 million scrap tires were added to the existing stockpile annually. Therefore, in the last decade, considerable research and development has been carried out for the use of tire crumbs in asphaltic pavement layers in Iran (Iran Transportation Research Institute, 2006) and it is also essential to find beneficial ways of recycling and/or reusing tires.

According to Humphrey (1999), using scrap tires in civil engineering projects are advantageous because of their low density, high durability, and high thermal insulation and in many cases least cost compared to other fill materials. These materials are used for reinforcing soft soil in road and embankment construction (Bosscher et al., 1997; Heimdah \& Druscher, 1999; Velazco et al., 2000; Zornberg \& LaRocque, 2005), as lightweight fill materials (Bosscher et al., 1997; Tatlisoz et al., 1998; Lee et al., 1999; Edil \& Bosscher, 1994), as an additive material to asphalt (Foose et al., 1996; Tuncan et al., 1998), as a source for creating heat (Lee et al., 1999), and as landfill barrier materials (Al Tabbaa \& Aravinthan, 1998; Al Tabbaa et al., 1997; Baykal \& Alpatly, 1995).

Bosscher et al. (1993) reported that an embankment constructed with sand-tire shreds operated satisfactorily even when subjected to heavy loads. They also found that the long-term settlement of such embankment could be alleviated if a soil cap with a thickness of $1 \mathrm{~m}$ overlies the sand-shred mixtures. Bosscher et al. (1997) performed large-scale models of tire-chips embankments and showed that tire chip-soil mixtures exhibit a significant initial plastic compression under load.

Lee et al. (1999) carried out triaxial tests on pure tire-chips and tire-chips mixed with sand. Youwai \& Bergado (2004) carried out drained triaxial compression tests on shredded tire-sand mixtures with different amount of tire-chips. They found that with an increase in sand content, the strength and unit weight of mixtures increase and deformation due to isotropic compression decreases. Rate of reduction in deformation was significant when the sand in the mixture was more than $30 \%$.

Former studies have mainly concentrated on determining engineering properties of tire-chips alone and/or various mixtures of tire-chips with sand as a lightweight fill material for embankment construction (Lee et al., 1999; Edil \& Bosscher, 1994; Foose et al., 1996; Garga \& Zargarbashi, 2002; Zornberg et al., 2004; Venkatappa \& Dutta, 2006; Vafaeian \& Mehran-Nia, 2006; Ghazavi \& Sakhi, 2005).

H. Soltani-Jigheh, Assistant Professor, Azarbaijan Shahid Madani University, Tabriz, Iran. e-mail: hsoltani@azaruniv.ac.ir.

V. Marefat, Lecturer, Bonab University, Velayat Highway, Bonab, East Azerbaijan, Iran. e-mail: v.marefat@bonabetu.ac.ir.

A. Ersizad, Master in Geotechnical Engineering, Islamic Azad University, Zanjan Branch, Zanjan, Iran. e-mail: ersizad@gmail.com.

Submitted on April 13, 2013; Final Acceptance on October 2, 2013; Discussion open until April 30, 2014. 
Some investigators have recently been studied the behavior of clay - tire mixtures. Cetin et al. (2006) added two types of tire-chips to clay and indicated that the shear strength increases up to $30 \%$ for fine and $20 \%$ for coarse tire-chip mixtures. Moreover, with the increase tire-chips up to $40 \%$ cohesion of samples increases, while the angle of internal friction decreases. For the tire-chips more than $40 \%$, the cohesion decreases, whereas the angle of internal friction grows up. They also demonstrate that under lower normal pressures percent of tire-chips do not have considerable effect on the vertical strains or volume change during shear. However, under higher normal pressures, originally high negative vertical strains for the clayey soil alone decrease considerably for the fine tire-chip mixtures or become slightly above zero or positive for the coarse tire-chips mixtures up to $50 \%$. They concluded that the dry densities of clay-tire chip mixtures are lower than that of pure clayey soil.

Özkul \& Baykal (2007) investigated the influence of rubber fiber inclusion on the shear behavior of low plasticity clay by performing a series of triaxial compression tests under confining stresses ranging from $50 \mathrm{kPa}$ to $300 \mathrm{kPa}$. They pointed that the contribution of rubber fibers to the strength of clay mixtures decreases with increasing levels of confining stress. A limit confining pressure also exists beyond which the presence of rubber fibers tend to degrade the strength of the clay.

When confining stresses are below this limit value the peak drained strength of the composite specimens is higher, occurs at greater strains, and has higher post peak strength in comparison with the associated values of unreinforced clay. During undrained loading, composite specimens again have higher peak strengths but show faster strength development compared to samples of clay alone. In addition, they showed that the deformation behavior of the clay is significantly changed.

Overview of the previous studies reveals that the effects of tire-chips content and clay characteristics on the behavior of clay - tire mixtures have not clearly been investigated (Cetin et al., 2006; Özkul \& Baykal, 2007). In addition, the studies on behavior of these mixtures under undrained loading condition are incomplete. With this intend, a number of undrained triaxial tests are carried out on the compacted specimens made of clay-tire chips mixtures. Then, the obtained results are compared with the associated behavior of pure clay and an analysis is performed in terms of tire-chips content and clay plasticity. It should be noted that the materials presented in this article is a part of a comprehensive study on clay-tire mixtures and the effect of tire-chips size on the behavior of these mixtures published previously by Marefat \& Soltani-Jigheh (2011).

\section{Materials and Methods}

\subsection{Materials and sample preparation}

Samples were prepared by mixing cohesive clayey soils with 10, 20 and $30 \%$ tire-chips, free of steel belts, by weight. The tire-chips used in the mixtures were obtained from a local waste tire manufacturing plant which grinds them for reusing. The size of tire-chips were between $4.75 \mathrm{~mm}$ (No. 4 sieve) and 1/4" sieve, with an average size of $5.53 \mathrm{~mm}$ and specific gravity of 0.988 .

Major part of clayey soil used in the mixtures was locally obtained from the Azarshahr clay deposits in EastAzarbaijan state. This cohesive soil has index properties of $\mathrm{LL}=33 \%, \mathrm{PI}=12 \%$, and $\mathrm{G}_{\mathrm{S}}=2.698$ and denoted with AC. To investigate the effect of clay plasticity on the characteristics of clay-tire mixtures, an artificial clay was prepared by mixing $80 \%$ AC clay with $20 \%$ commercial bentonite. This clay is characterized by ACB and has index properties of $\mathrm{LL}=61 \%$, PI $=33 \%$, and $\mathrm{G}_{\mathrm{S}}=2.64$ (Table 1). According to Unified Soil Classification System (USCS), AC and ACB clays were categorized as $\mathrm{CL}$ and $\mathrm{CH}$, respectively (ASTM, 2008a). Mineral component and index properties of these clays are also listed in Table 1. Grading curves of tire-chips and clayey soils are depicted in Fig. 1 and also some grading specifications of these materials are listed in Table 2.

In order to model samples closely the prototype conditions, standard Proctor compaction tests were performed on the clayey soils and mixtures to determine compaction characteristics (ASTM, 2008b). The resulting compaction curves provide information on maximum dry unit weight $\left(\gamma_{\text {dmax }}\right)$ and optimum water content $\left(w_{\text {opt }}\right)$. Names of tested samples as well as some of their specifications are listed in Table 3. In the name of specimens, R3 shows the tire-chips

Table 1 - Mineral components and index properties of clayey soils.

\begin{tabular}{lcc}
\hline Clay type & AC & ACB \\
\hline Minerals & & \\
Calcite (\%) & 59 & 26 \\
Quartz (\%) & 17 & 21 \\
Feldspar (\%) & 12 & 14 \\
Clay minerals (\%) & $11^{*}$ & $37 * *$ \\
Other mineral & 1 & 2 \\
\hline Consistency indices & & \\
Liquid limit (\%) & 33 & 61 \\
Plastic limit (\%) & 21 & 28 \\
Plasticity index & 12 & 33 \\
Specific gravity & 2.698 & 2.64 \\
USCS classification & $\mathrm{CL}$ & $\mathrm{CH}$ \\
\hline
\end{tabular}

*This value indicates total percentage of clay minerals by weight, which mainly consists of Kaolinite, Illite, Chlorite and Montmorillonite, respectively.

**This value indicates total percentage of clay minerals by weight, which mainly consists of Montmorillonite, Kaolinite and Illite, respectively. 


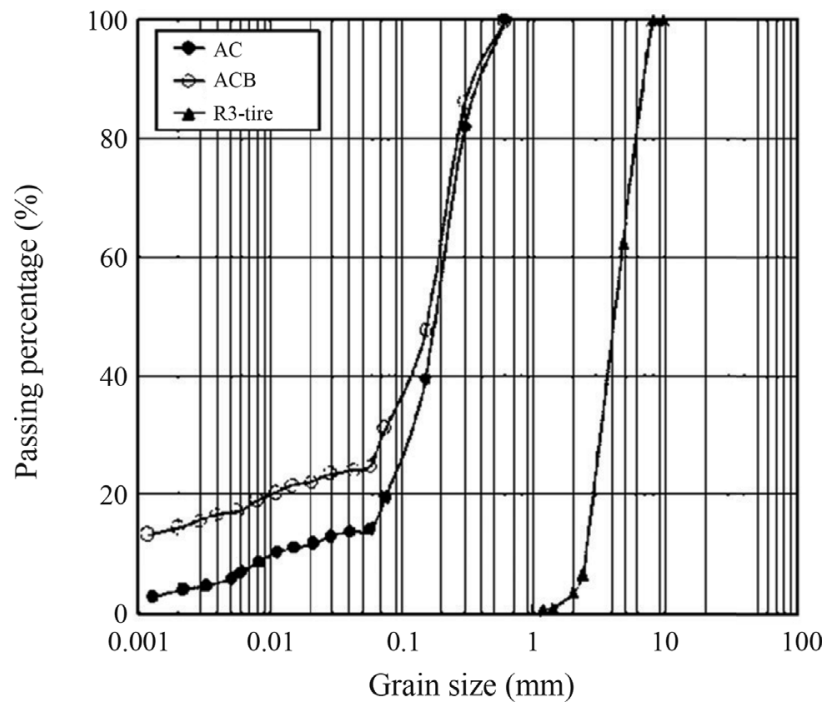

Figure 1 - Particle size distribution of used materials.

Table 2 - Some properties of used materials.

\begin{tabular}{lccc}
\hline Material & AC & ACB & R3-tire \\
\hline $\mathrm{D}_{10}$ & 0.01 & - & 2.5 \\
$\mathrm{D}_{30}$ & 0.14 & 0.07 & 3.4 \\
$\mathrm{D}_{60}$ & 0.19 & 0.21 & 4.6 \\
$\mathrm{C}_{\mathrm{u}}$ & 19 & $>25$ & 1.84 \\
$\mathrm{C}_{\mathrm{c}}$ & 10.31 & - & 1.005 \\
\hline
\end{tabular}

in the mixtures and $\mathrm{AC}$ and $\mathrm{ACB}$ stand for the type of clay matrix. The numbers denote the clay percent in weight; e.g., the specimen made of $80 \%$ AC clay and $20 \%$ R3 tire-chips was named as R3-AC80.

Soil specimens were then compacted in $50 \mathrm{~mm}$ diameter and $100 \mathrm{~mm}$ height steel mold with density of $0.95 \gamma_{\text {dmax }}$ at $1 \%$ of the optimum moistures. In order to obtain a uniform mixture, water was sprayed onto the surface of the materials and then mixed and placed in sealed plastic bags and stored overnight in a controlled humidity room.

Due to the presence of tire-chips, it was impossible to cut or trim compacted composite soil without causing considerable disruption. Hence, the specimens had to be compacted into a mold that was suitably sized for triaxial testing. A special splitting type cylindrical mold of $50 \mathrm{~mm}$ diameter and $100 \mathrm{~mm}$ height was used.

\subsection{Shear Testing}

After extruding the specimens from the mold, they were set up in triaxial cell. The triaxial apparatus had an automatic data acquisition and logging system was used during all stages of testing to periodically record cell pressure, back pressure, pore water pressure, load and deformation of tested specimens. A manually volume change was con- nected to the backpressure line for obtaining the volume change of specimens.

Standard consolidated undrained (CU) triaxial testing procedures were followed (ASTM, 2008c). To saturate the specimens, distilled water was transmitted through them and then incremental backpressure saturation with a pressure differential of $30 \mathrm{kPa}$ was applied. The backpressure was raised to a maximum of $375 \mathrm{kPa}$ and B value was calculated for each increment. Saturation of the specimens took approximately 4-7 days to complete until reaching at least $B$-value of 0.97 . The specimens were consolidated under three different effective consolidation stresses of 100 , 200 , and $300 \mathrm{kPa}$. Shearing was applied to the specimens with deformation rates of $0.05 \mathrm{~mm} / \mathrm{min}$ until reaching up to $18 \%$ strain and simultaneously shear-induced pore water pressure was measured.

\section{Typical Test Results}

Considering the large number of the tests, it is not possible to present all of their immediate results; hence, only typical results are introduced. However, all of the immediate results are compiled, analyzed, and presented in the following sections. The results of the tests on ACB100 and R3-AC80 specimens are typically presented in Figs. 2 and 3. These figures show variations of deviatoric stress $v s$. axial strain $\left(\varepsilon_{\mathrm{a}}\right)$, excess pore water pressure $(\Delta \mathrm{u}) v s . \varepsilon_{\mathrm{a}}$, and deviatoric stress $\left(\mathrm{q}^{\prime}=\sigma_{1}{ }_{1}-\sigma^{\prime}{ }_{3}\right) v s$. mean normal effective stress $\left(\mathrm{p}^{\prime}=\left(\sigma^{\prime}{ }_{1}+2 \sigma^{\prime}{ }_{3}\right) / 3\right)$.

\section{Analysis of Results}

\subsection{Stress-strain behavior}

A comparison of the stress-strain behavior of clay-tire mixtures with different amounts of $\omega_{R}$ was complied. Typical results of these comparisons for different R3-AC and R3-ACB specimens under $\sigma^{\prime}{ }_{3}=300 \mathrm{kPa}$ are presented in Figs. 4 and 5, respectively. In general, it can be observed that at low level of strains, the unamended clays is stronger than the clay-tire chip mixtures (Figs. 4a and 5a). In contrast, in high level of strains the trend is different; some mixtures are stronger than the pure clay and some others are weaker than the pure clays. In general, the effect of tirechips on the stress-strain curves is not considerable.

\subsection{Shear strength}

To study the effect of tire content on the shear strength of clayey soils, the variations of shear strength of specimens has been plotted in terms of tire-chips content (Fig. 6). As illustrated in this figure, the effect of tire-chips on the shear strength of clays depends on the clay plasticity. The shear strength of AC clay-tire mixtures reduces as the tire content $\left(\omega_{\mathrm{R}}\right)$ increases (in comparison with the associated values of unamended clay) until reaching a minimum value at a given tire content. After this given value, by increasing tire content in the specimens the shear strength 
rises up. This given value for $\omega_{\mathrm{R}}$ is about $10 \%-20 \%$ dependent on the value of $\sigma$ '. The shear strengths of specimens amended with $30 \%$ tire approximately equal to associated values of unamended clay. In contrast, for ACB clay-tire
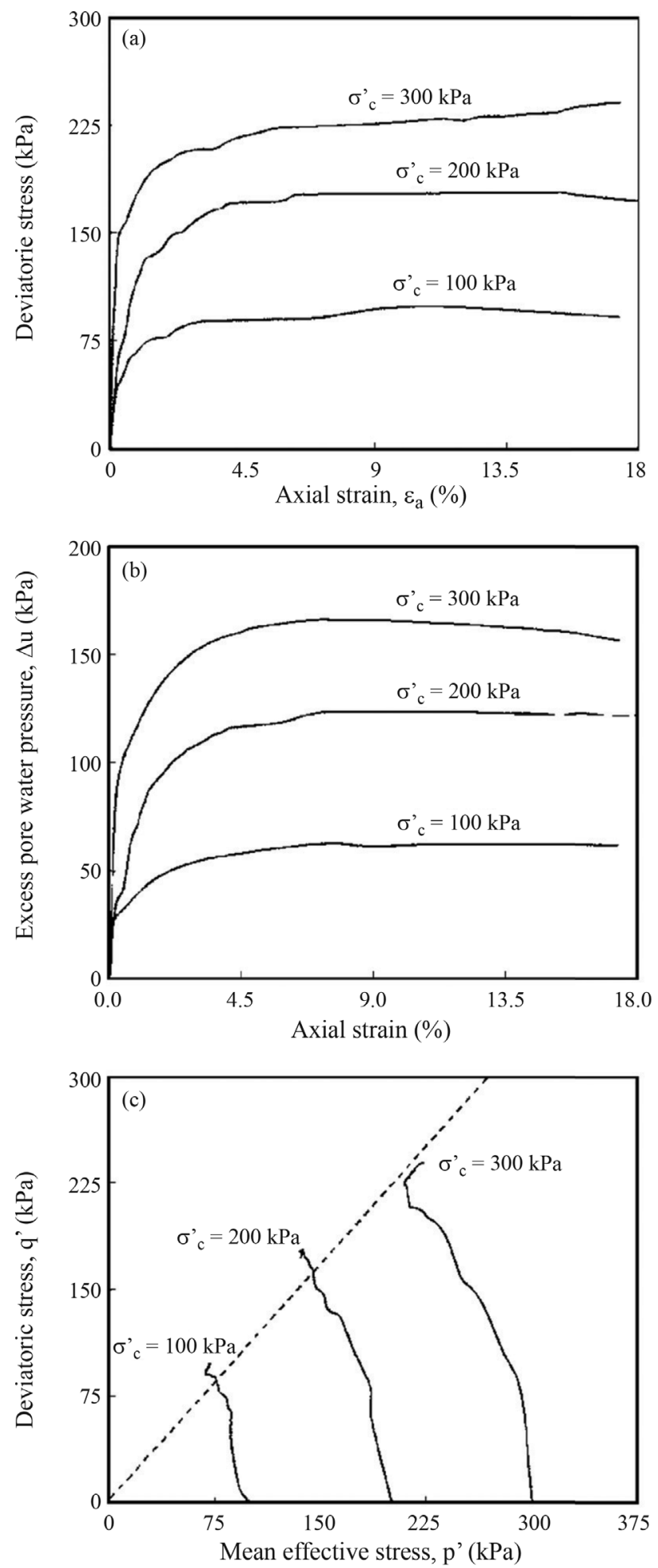

Figure 2 - Results of the tests on ACB100 specimen: a) stressstrain plots, b) $\Delta \mathrm{u} v s . \varepsilon_{\mathrm{a}}$, and c) stress paths on q'-p' space. mixtures, the shear strength reduces slightly as the tire content increases.

From Fig. 6, it can be realized that the shear strength of mixtures of high plasticity clay decreases with increas-
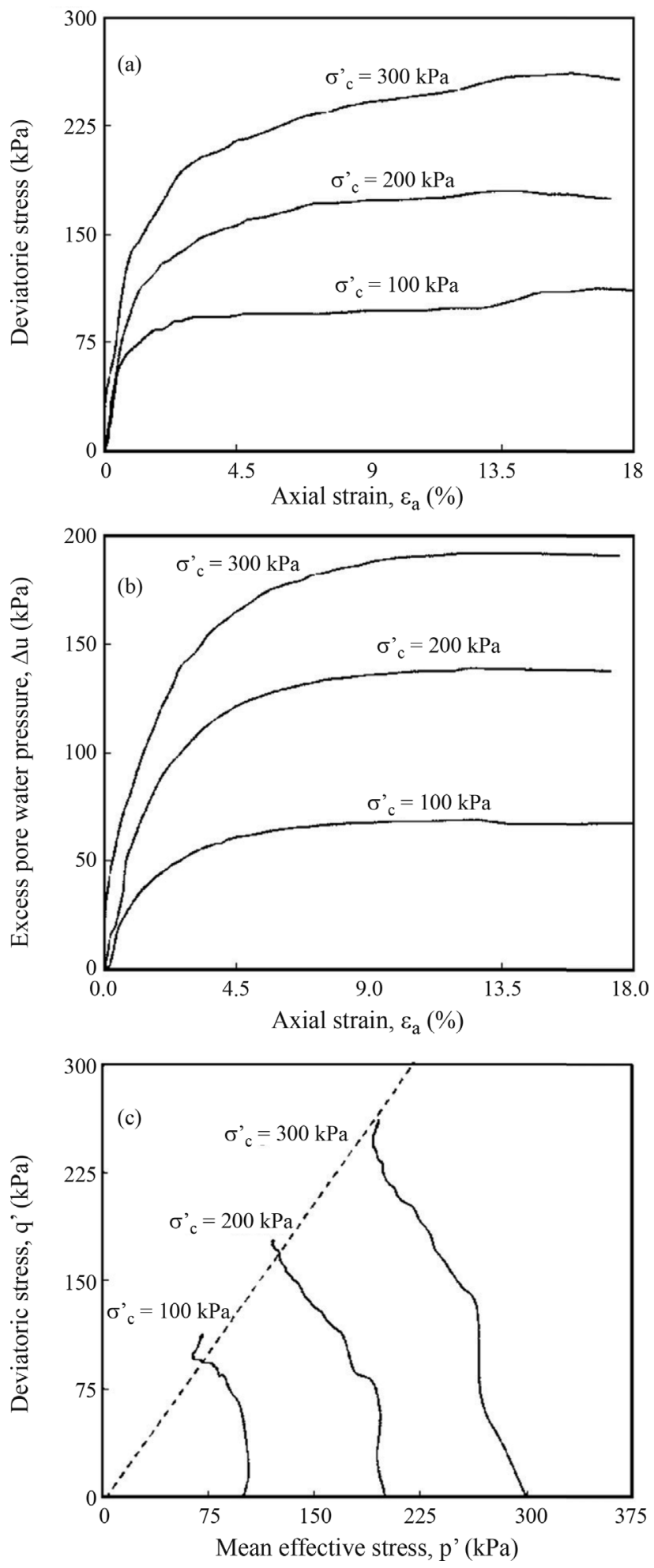

Figure 3 - Results of the tests on R3-AC80 specimen: a) stressstrain plots, b) $\Delta \mathrm{u} v s$. $\varepsilon_{\mathrm{a}}$, and c) stress paths on q'-p' space. 

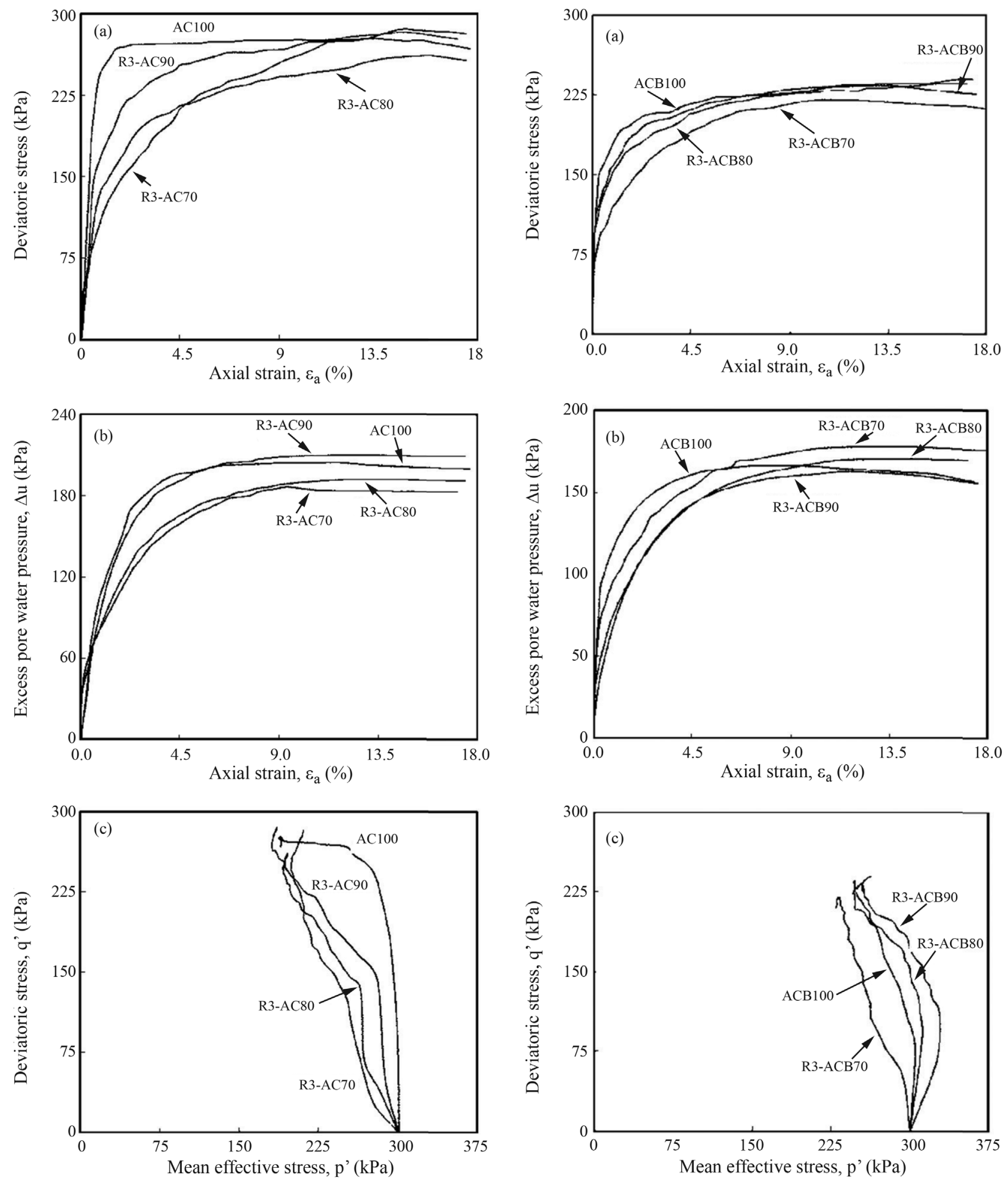

Figure 4 - Behavior of R3-AC specimens under $\sigma^{\prime}{ }_{\mathrm{c}}=300 \mathrm{kPa}$ : a) stress-strain plots, b) $\Delta \mathrm{u} v s . \varepsilon_{\mathrm{a}}$, and c) stress paths on q'-p' space.

ing the tire content. While for the specimens made of low plasticity clay, it is abated to a given value of $\omega_{R}$, and then the trend is altered conversely.

In addition, to investigate the effect of tire-chips on the values of shear strength parameters, the values of internal friction angle ( $\left.\phi^{\prime}\right)$ and cohesion (c') evaluated in terms 
of tire contents, as depicted in Fig. 7. It can be found that the changing $\phi$ ' and c' values with $\omega_{\mathrm{R}}$ are completely vice versa in the mixtures of $\mathrm{AC}$ and $\mathrm{ACB}$ clays.
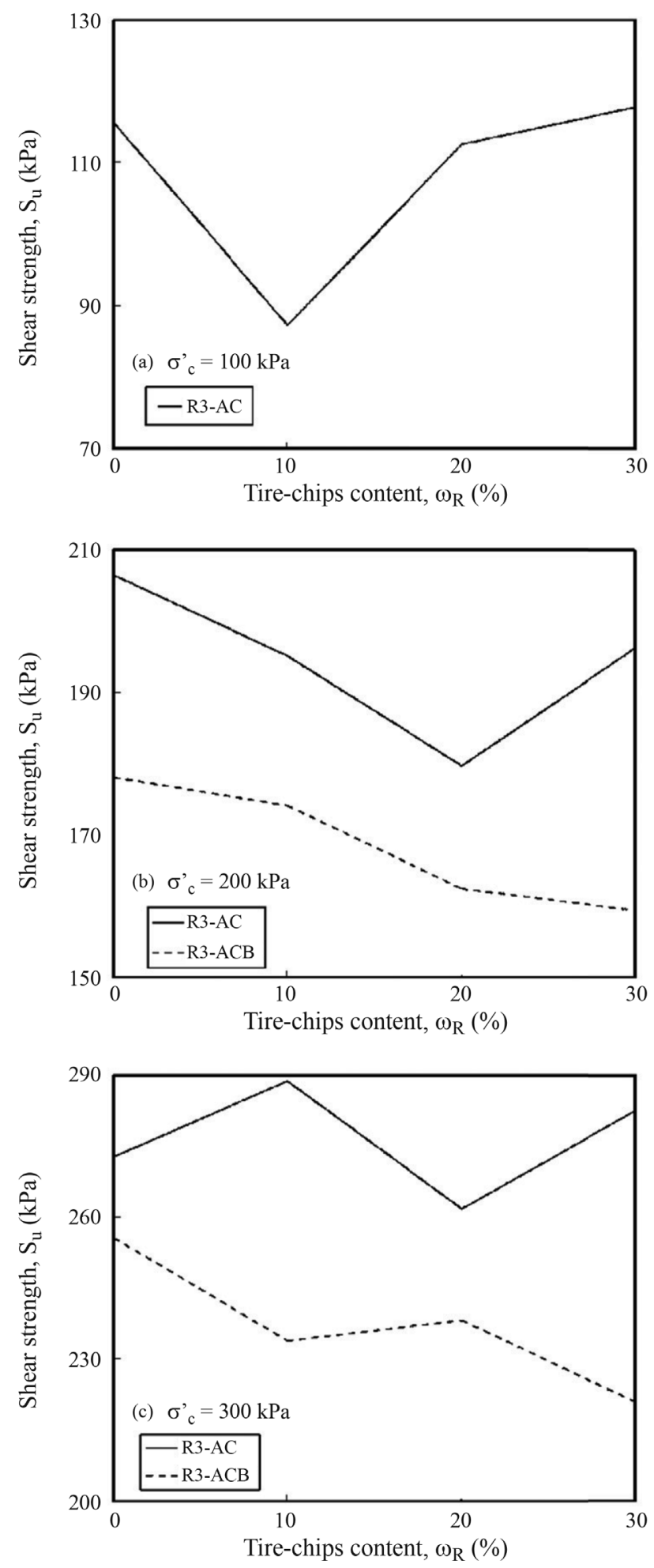

Figure 6 - Effect of tire-chips on the shear strength of specimens under $\sigma^{\prime}$ of: a) $100 \mathrm{kPa}$, b) $200 \mathrm{kPa}$, and c) $300 \mathrm{kPa}$.
As illustrated in Fig. 7b, the friction angle of R3AC90 specimen is higher than that of other specimens of R3-AC. The $\phi$ ' values of R3-AC80 and R3-AC70 specimens are lower than the associated value of AC100 specimen. Unlike, for the mixtures of ACB clay, the minimum value of $\phi$ ' obtained for the specimen with $\omega_{R}=10 \%$, and beyond this $\omega_{\mathrm{R}}$, the values of $\phi$ ' increase with increasing tire content. The $\phi$ ' values of R3-ACB80 and R3-ACB70 specimens are greater than the associated value of unamended clay.

Figure $7 \mathrm{~b}$ shows that changing cohesion parameter with tire content is strictly in contrast with the trends of $\phi$ ' in associated mixtures. The values of $c^{\prime}$ are the least and the most respectively for the mixed specimens of AC and ACB clays consist of $10 \%$ tire-chips. Thereafter, adding tirechips to the clays causes the cohesion increases and decreases, respectively. Similar trend for $\phi$ ' and c' was reported by Cetin et al. (2006) for mixtures comprising low plasticity clay.

To interpret the effect of tire-chips on the shear strength parameters, it can be said that AC clay includes
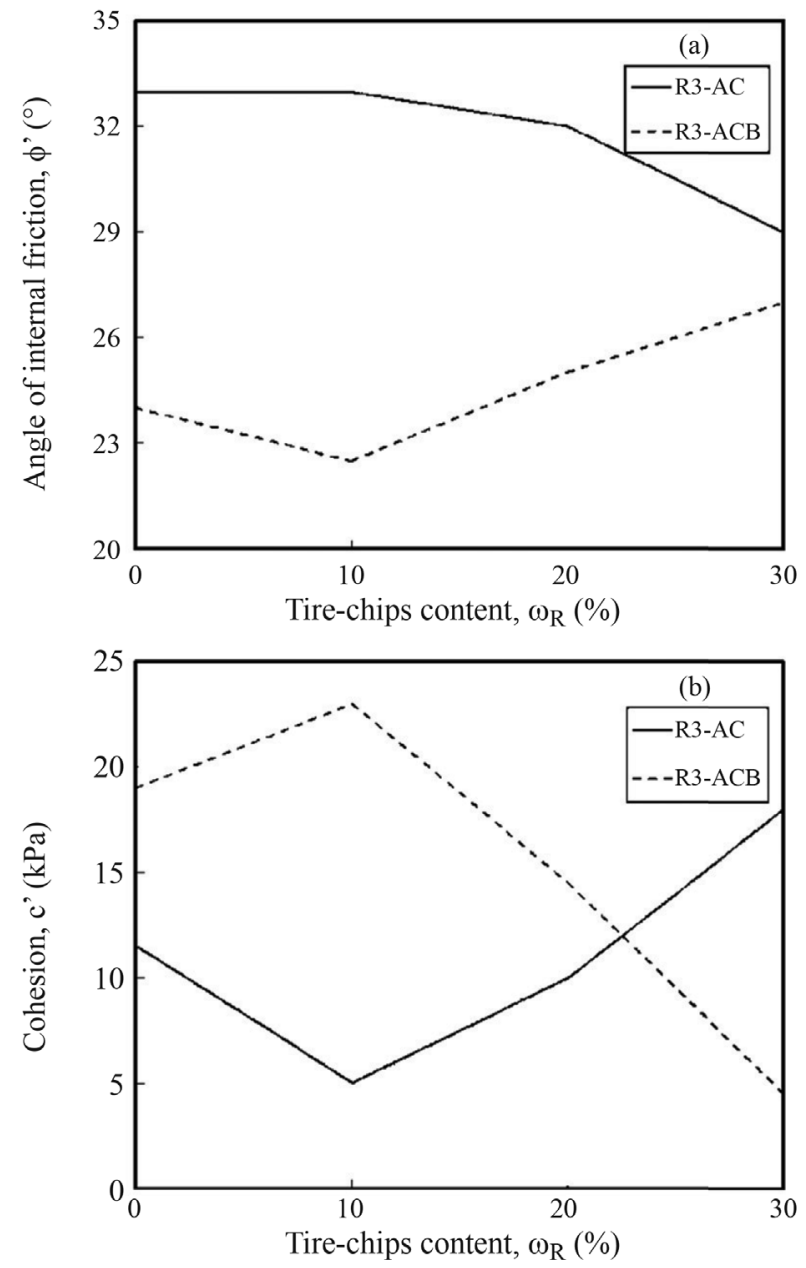

Figure 7 - Variations of a) friction angle, and b) cohesion, vs. tire content. 
low content of cohesive clay minerals and its shear strength is mostly based on the friction between particles and cohesion between soil particles plays small role. One may be concluded that the non-clay minerals of soil are stiffer than additive tire-chips; in other words, the total hardness of AC clay is higher than tire-chips. Thereupon, inclusion of tirechips reduces the friction angle; because tire-chips induce space between frictional particles or change contact structure to floating structure. The compaction may also induce cohesion between tire-chips and soil particles, which is higher than the cohesion between soil particles in low plasticity clay. Therefore, inclusion of tire chips heightens the cohesion values in $\mathrm{AC}$ mixtures.

Reversely, in high plasticity ACB clay, content of clay minerals is high, in general the soil is softer, and also its shear strength is mostly based on the cohesion between soil particles. When the tire-chips are added to the clay, the attractive force between clay minerals reduces which is lead to reduction in cohesion. Moreover, the tire-chips are stiffer than the predominant minerals of ACB clay, which cause to increase the friction angle of mixtures.

Comparison of failure envelopes of samples (see Fig. 8 and Table 3) shows that slope of the envelopes (M) does not affected significantly by inclusion of tire-chips to the clay.

\subsection{Deformability}

Secant deformation modulus $\left(\mathrm{E}_{50}\right)$ is an index of specimen deformability. Therefore, the values of $E_{50}$ for the specimens obtained from the associated stress-strain curves (Table 4) and variations of them plotted in terms of tirechips content as indicated in Fig. 9. This figure shows that, irrespective of clay matrix, the values of secant deformation modulus decreases with increasing tire-chips content; in other words, the deformability of specimens rises as $\omega_{R}$ increases. The rate of reduction is considerable for the

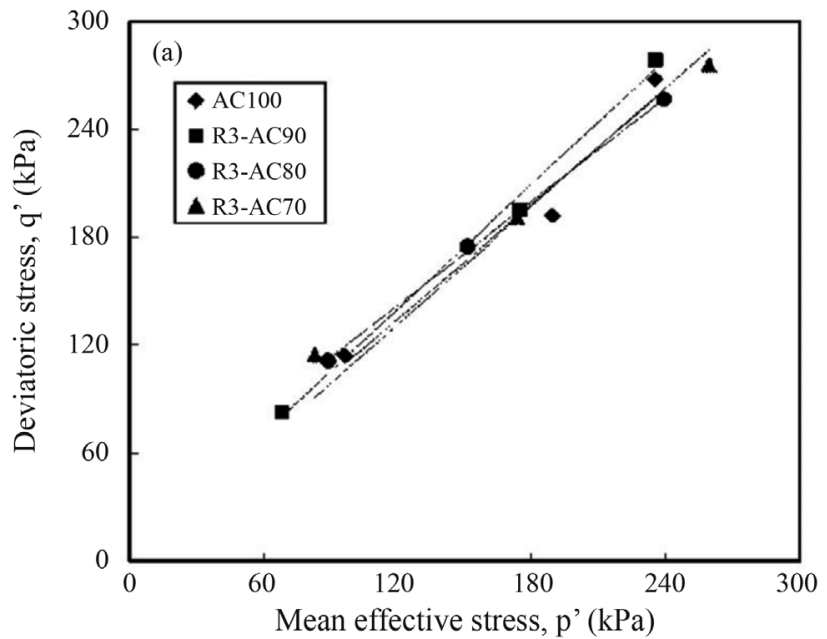

Table 3 - List of specimens with some specifications.

\begin{tabular}{lccccc}
\hline $\begin{array}{l}\text { Specimen des- } \\
\text { ignation }\end{array}$ & $\begin{array}{c}\text { Clay } \\
(\%)\end{array}$ & $\begin{array}{c}\text { Tire, } \\
\omega_{\mathrm{R}}(\%)\end{array}$ & $\begin{array}{c}\gamma_{\mathrm{dmax}} \\
\left(\mathrm{kN} / \mathrm{m}^{3}\right)\end{array}$ & $\begin{array}{c}\mathrm{w}_{\text {opt }} \\
(\%)\end{array}$ & $\mathrm{M}$ \\
\hline AC100 & 100 & 0 & 16.35 & 19.50 & 1.104 \\
R3-AC90 & 90 & 10 & 15.20 & 19.54 & 1.190 \\
R3-AC80 & 80 & 20 & 14.40 & 18.00 & 1.148 \\
R3-AC70 & 70 & 30 & 13.80 & 16.25 & 1.158 \\
ACB100 & 100 & 0 & 14.78 & 21.75 & 1.000 \\
R3-ACB90 & 90 & 10 & 13.63 & 18.51 & 0.940 \\
R3-ACB80 & 80 & 20 & 13.42 & 19.25 & 0.944 \\
R3-ACB70 & 70 & 30 & 13.10 & 20.25 & 0.948 \\
\hline
\end{tabular}

higher values of $\sigma^{\prime}$, and it is about $70 \%-80 \%$ for $\sigma_{\mathrm{c}}=300 \mathrm{kPa}$.

\subsection{Excess pore water pressure (EPWP or $\Delta \mathbf{u})$}

Comparison of Figs. 4a and 5a shows that shearinduced pore water pressure of unamended clays at low level of strains are higher than the similar values of mixed specimens, but at high level of strains the trend is changed. Maximum values of EPWP $\left(\Delta \mathrm{u}_{\max }\right)$ of the specimens vs. tire-chips content are presented in Fig. 10. This figure explains that the effect of tire-chips on $\Delta \mathrm{u}_{\max }$ depends on the type of clay. For the mixtures of AC clay, $\Delta \mathrm{u}_{\max }$ rises at first with increasing tire content up to $10 \%-20 \%$, dependent on the values of confining stress and, afterward, it begins to reduce. For the mixtures made of ACB clay, inclusion of tire-chips to the clay lead to decrease pore water pressure slightly at $\sigma_{\mathrm{c}}=200 \mathrm{kPa}$. But at consolidation stress of $300 \mathrm{kPa}$, maximum EPWP increases with an increase in tire-chips content. However, the effect of tire-chips on the excess pore water pressure in not most considerable and it is about $8 \%-15 \%$.

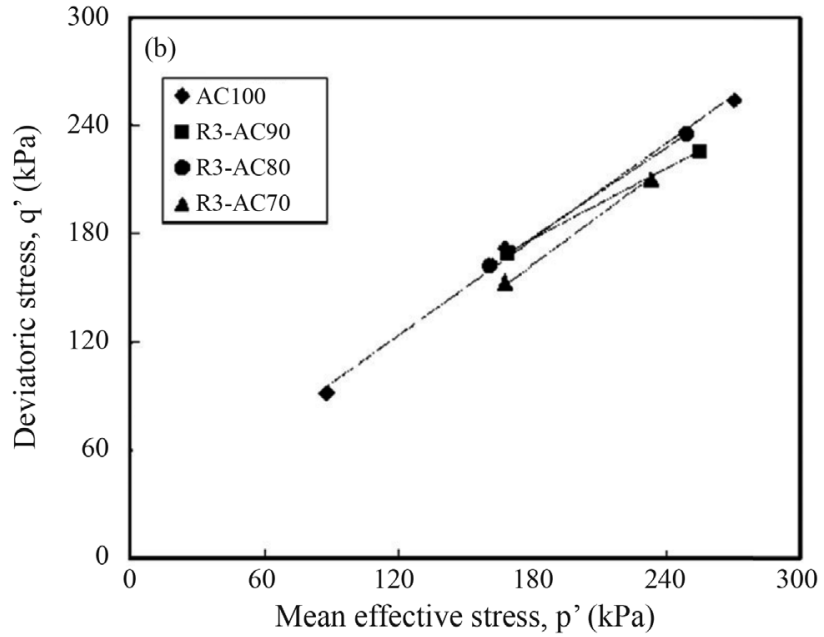

Figure 8 - Failure envelops of specimens comprising: a) AC clay, and b) ACB clay. 

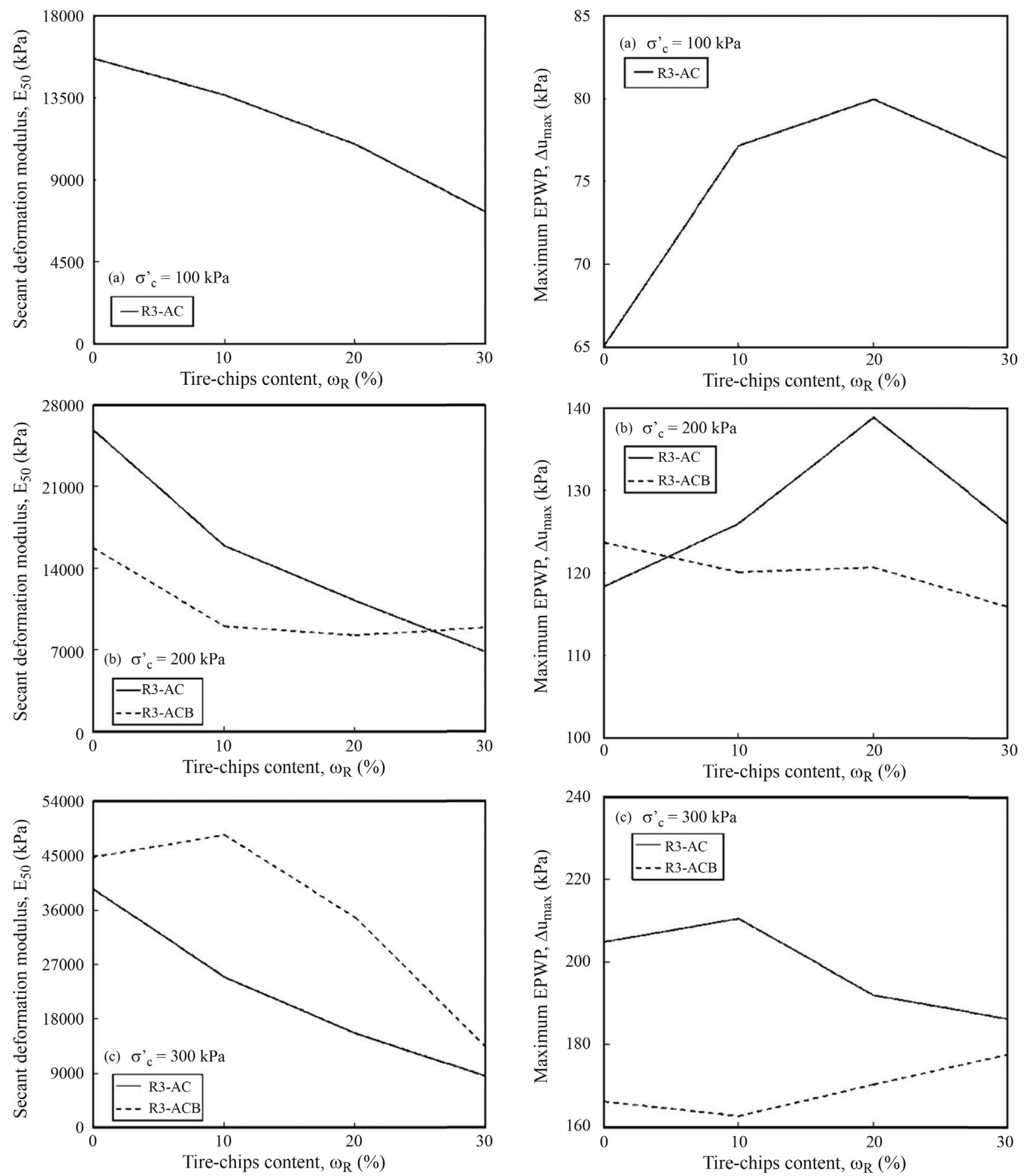

Figure 9 - Secant deformation modulus vs. tire chips content for: a) $\mathrm{AC}$, and b) $\mathrm{ACB}$, clay mixtures.

\subsection{Stress paths}

Study the stress paths indicates that at low level of strains the behavior of all the AC clay mixed specimens are contractive, but at large level of strains the behavior of

Figure 10 - Effect of tire-chips content on $\Delta u_{\max }$ values at $\sigma^{\prime}$ : a) $100 \mathrm{kPa}$, b) $200 \mathrm{kPa}$, and c) $300 \mathrm{kPa}$.

R3-AC80 and R3-AC70 specimens changes from contractive to dilative one. The results explain that the ACB100 and R3-ACB90 specimens have dilative behavior and with increasing $\omega_{\mathrm{R}}$ from $10 \%$ to $30 \%$ the behaviors change from dilative to contractive one. 
Table 4 - Values of $\mathrm{E}_{50}$ for all of the tested specimens.

\begin{tabular}{lcccc}
\hline \multirow{2}{*}{$\begin{array}{l}\text { Specimen } \\
\text { designation }\end{array}$} & Tire, $\omega_{\mathrm{R}}(\%)$ & \multicolumn{3}{c}{$E_{50}\left(\mathrm{kN} / \mathrm{m}^{2}\right)$} \\
\cline { 3 - 5 } & & $\sigma^{\prime}{ }_{\mathrm{c}}=100 \mathrm{kPa}$ & $\sigma^{\prime}{ }_{\mathrm{c}}=200 \mathrm{kPa}$ & $\sigma_{\mathrm{c}}=300 \mathrm{kPa}$ \\
\hline AC100 & 0 & 15635 & 25887 & 39503 \\
R3-AC90 & 10 & 13678 & 15950 & 24954 \\
R3-AC80 & 20 & 10961 & 11235 & 15649 \\
R3-AC70 & 30 & 7261 & 6840 & 8386 \\
ACB100 & 0 & - & 15745 & 44780 \\
R3-ACB90 & 10 & - & 8997 & 48495 \\
R3-ACB80 & 20 & - & 8265 & 34756 \\
R3-ACB70 & 30 & - & 8911 & 13218 \\
\hline
\end{tabular}

It can be concluded that adding the tire-chips to the clay changes the tendency of specimens during shearing. The change in tendency depends on the plasticity of clay matrix. Specimens made of low plasticity clay tend to contract during shearing, while adding tire-chips causes they exhibit dilative behavior. In contrast, specimens consisting of high plasticity clay represent relatively dilative behavior, whereas the mixtures of this clay with higher values of tire-chips tend to contract.

\section{Conclusions}

In the present study, a number of undrained triaxial tests were carried out on the compacted clay-tire mixtures and their behaviors were compared with the behavior of the unamended clay. The compaction tests showed that the units weights of mixed specimens are about 11\%-17\% lower than those of unamended clays. The majority of this decrease is due to the lower specific gravity of tire-chips.

The results of triaxial tests indicated that adding more than $20-30 \%$ tire-chips to the low plasticity clay don't reduce the shear strength in comparison with the associated values of unamended clays. While, in the mixtures made of high plasticity clay, as tire content increases the shear strength of specimen decreases. In addition, the friction angle and cohesion parameters are obviously dependent on the tire chips content and clay plasticity. However, tirechips in the range of $10 \%$ to $30 \%$ don't influence the shear strength much more, but it has considerable effect on the deformation modulus.

Also the results showed that when tire-chips added to the low plasticity clay, maximum excess pore water pressure occurs at tire content about $10 \%-20 \%$. For the mixtures made of high plasticity clay, the pore water pressure under low consolidation stress decreases slightly as the tire content decreases, while, it is increased with tire-chips content at high consolidation stress.

Finally, it can be concluded that possible usage of clay-tire mixtures as light construction material exists in the earth structures, without considerable reduction in shear strength. Hereby, it can be managed the waste tire materials and embedded them within the ground.

\section{Acknowledgments}

The authors greatly appreciate the financial assistance providing by the Bonab University.

\section{References}

Al Tabbaa, A. \& Aravinthan, T. (1998) Natural clayshredded tire mixtures as landfill barrier materials. Waste Management, v. 18:1, p. 9-16.

Al Tabbaa, A.; Blackwell, O. \& Porter, S. A. (1997) An investigation into the use of soil-tire mixtures as construction material. Journal of Environmental Technology, v. 18:9, p. 913-920.

ASTM (2008a) Standard Practice for Classification of Soils for Engineering Purpose (Unified Soil Classification System) - D 2487-00. ASTM International, West Conshohocken, Pennsylvania, USA, 11 pp.

ASTM (2008b) Standard Test Methods for Laboratory Compaction Characteristics of Soil Using Standard Effort- D 698-00. ASTM International, West Conshohocken, Pennsylvania, USA, 11 pp.

ASTM (2008c) Standard Test Methods for Consolidated Undrained Triaxial Compression Test for Cohesive Soils- D4767-95. ASTM International, West Conshohocken, Pennsylvania, USA, 11 pp.

Baykal, G. \& Alpatly, H.M. (1995) Permeability of tire soil liners under confinement. Proc. Geoenvir. 2000, Geotechnical Special Publication No. 46, Y.B. Acar \& D.E. Daniel (eds), New Orleans, pp. 718-731.

Bosscher, P.J.; Edil, T.B. \& Eldin, N. (1993) Construction and performance of shredded waste tire test embankment. Transportation Research Record No. 1345, Transportation Research Board, Washington, D.C., pp. 44-52.

Bosscher, P.J.; Edil, T.B. \& Kuraoka, S. (1997) Design of highway embankments using tire chips. ASCE Journal of Geotechnical and Geoenvironmental Engineering, v. 123:4, p. 295-304. 
Cetin, H.; Fener, M. \& Gunaydin, O. (2006) Geotechnical properties of tire-cohesive clayey soil mixtures as a fill material. Engineering Geology, v. 88:1-2, p. 110-120.

Edil, T.B. \& Bosscher, P.J. (1994) Engineering properties of tire chips and soil mixtures, ASTM Geotechnical Testing Journal,v. 17:4, p. 453-464.

Foose, G.J.; Benson, C.H. \& Bosscher, P.J. (1996) Sand reinforced with shredded waste tires, Journal of Geotechnical Engineering Division, v. 122:9, p. 760-767.

Garga, V.K. \& Zargarbashi, S. (2002) Shear strength analysis of backfill reinforced with shredded tires, Paramètres de calcul géotechnique. Magnan (ed.), Presses de l'ENPC/ LCPC, Paris.

Ghazavi, M. \& Sakhi, M.A. (2005) Optimization of aspect ratio of waste tire shreds in sand-shred mixtures using CBR tests. Geotechnical Testing Journal, v. 28:6, p. 1-6.

Heimdah, C. \& Druscher, A. (1999) Elastic anisotropy of tire shreds. ASCE Journal of Geotechnical and Geoenvironmental Engineering, v. 125:5, p. 383-389.

Humphrey, D.N. (1999) Civil engineering applications of tire shreds. Proc. Tire Industry Conf., Clemson University, March 3-5.

Iran Transportation Research Institute. (2006) Research reports for 2005. Ministry of Road and Transport, Tehran, Iran, http://www.rahiran.ir/premier.htm.

Lee, J.H.; Salgado, R.; Bernal, A. \& Lovell, C.W. (1999) Shredded tires and tire-sand as light weight backfill, ASCE Journal of Geotechnical and Geoenvironmental Engineering, v. 125:2, p. 132-141.

Marefat, V. \& Soltani-Jigheh, H. (2011) Laboratory behavior of clay-tire mixtures, World Apply Science Journal, IDOSI Publications, v.13:5, p. 1035-1041.

Özkul, Z.H. \& Baykal, G. (2007) Shear behavior of compacted tire fiber-clay composite in drained and undrained loading. ASCE Journal of Geotechnical and Geoenvironmental Engineering, v. 133:7, p. 767-781.

Rubber Manufacturer's Association. 2013, U.S. scrap tire management summary, 2005-2009, Updated September 2013, http://www.rma.org

Tatlisoz, N.; Edil T.B. \& Benson, C. (1998) Interaction between reinforcing geosynthetics and soil-tire chip mixtures. ASCE Journal of Geotechnical and Geoenvironmental Engineering, v. 124:11, p. 1109-19.
Tuncan, M.; Cetin, A.; Tuncan, A. \& Koyuncu, H. (1998) Assessment of waste tires and plastic on asphalt concrete pavement mixtures. Proc. 3rd Int. Cong. Envir. Geotech., Lisbon, Portugal, v. 2, pp. 667-672.

Youwai, S. \& Bergado, D.T. (2004) Numerical analysis of reinforced wall using tire chips-sand mixtures as backfill material. Computers and Geotechnics, v. 31:2, p. 103-114.

Vafaeian, M. \& Mehran-Nia, N.(2006) Evaluating the effect of waste fibers from the tire manufacturing in reinforcing the soil, 7th Int. Conf. of Civil Engrg., Tarbiat Modarres Uni. Tehran, No. F1696.

Velazco, D.; Rashid, H.; Tandon, V.; Ashur, S.; Nazarian, S. \& Picornell, M. (2000) Design and installation of instrumentation for performance monitoring of tire chip embankments, Research Report No.4930-1F, Conducted for Texas Department of Transportation.

Venkatappa Rao, G. \& Dutta, R.K. (2006) Compressibility and strength behaviour of sand-tyre chip mixtures. Geotechnical and Geological Engineering, v. 24:3, p. 711724.

Zornberg, J.G.; Cabral, A.R. \& Viratjandr, C. (2004) Behaviour of tire shred - Sand mixtures. Canadian Geotechnical Journal, v. 41:2, p. 227-241.

Zornberg, J.G. \& LaRocque, C.J. (2006). Engineering properties of tire bales for soil repairs and embankment construction, Report No. 5-9023-01-1, Center for Transportation Research at the University of Texas at Austin, August 2005; Revised February 2006.

\section{List of Symbols}

$\mathrm{E}_{50}=$ Secant deformation modulus

$\mathrm{LL}=$ Liquid limit

$\mathrm{M}=$ Slope of failure line

$\mathrm{PI}=$ Plasticity index

$\mathrm{p}^{\prime}=$ Mean effective stress $\left(=\left(\sigma_{1}^{\prime}+2 \sigma_{3}{ }_{3}\right) / 2\right)$

$\mathrm{w}=$ Water content

$w_{g}=$ Granular material content

$\Delta \mathrm{u}=$ Shear-induced excess pore water pressure

$\Delta \mathrm{u}_{\max }=$ Maximum shear-induced excess pore water pressure

$\gamma_{\mathrm{d}}=$ Dry density

$\sigma^{\prime}=$ Effective consolidation stress

$\mathrm{q}^{\prime}=$ Deviatoric stress $\left(=\sigma_{1}-\sigma_{3}\right)$ 


\title{
Numerical Analysis of El-Agrem Concrete Face Rockfill Dam
}

\author{
B. Moussai
}

\begin{abstract}
For concrete face rockfill dams, the behaviour of the concrete slab which provides the watertightness of the dam is a major concern. The deformation of the dam embankment during construction and operation leads to concrete slab deformation. This deformation should be compatible with the structural integrity of the concrete slab. This paper presents the numerical analysis of El-Agrem concrete face rockfill dam during reservoir filling using the finite element code Plaxis 2D-2010. Two models are used in this study, the Mohr Coulomb model and the Hardening Soil model to emphasize the impact of constitutive model on the dam deformation. The material stiffness parameters used in constitutive models were calibrated based on the available measured crest settlement. The analysis results indicate that the face slab deformation can be numerically predicted based on monitoring data at the dam crest and the Hardening Soil model gives a maximum slab deformation less than that obtained using Mohr Coulomb model.
\end{abstract}

Keywords: concrete face rockfill dam, stress-strain analysis, concrete slab deformation, rockfill behaviour.

\section{Introduction}

In recent years, the construction of concrete face rockfill dams has known a considerable interest in many parts of the world. The speed of construction, steep slopes, stabilizing effect of water load and resistance to seismic loading are some advantages of this type of dams compared to other types of embankment dams. However, the problems we may encounter with concrete face rockfill dams are the vulnerability of perimetric joints, deformations, cracks and aging of the concrete face slab.

The performance of a concrete face rockfill dam depends mainly on the performance of its concrete face slab. Won \& Kim (2008) studied the post-construction deformation of concrete face rockfill dams based on data published in the literature and showed that the crest and slab deformations depend mainly on the intact strength of the rockfill. They noticed that about $80 \%$ of the total long-term (after at least 10 years) deformation normal to the face slab occurs during the first filling and it is smaller than $0.5 \%$ of the dam height.

For concrete face rockfill dams, the most significant parameters to monitor are the deformation of the crest, the deformation of the concrete slab and the quantity of seepage through it. Crest deformation is usually obtained using surveying methods whereas the deformation of the concrete slab can be monitored by instruments such as inclinometers or settlement gauges. These instruments placed underwater are difficult to check or maintain and may fail to work. Therefore, in many dams, slab deformation measurements are not available such as Dix river dam, Kangaroo Creek dam, Little Para dam, Mangrove Creek dam, Serpentine dam, Wishon dam, etc. (Hunter et al., 2003).

The objective of this study is the prediction of the face slab deformation of El-Agrem concrete face rockfill dam based on available monitoring data at the dam crest using the finite element code Plaxis 2D-2010. The analyses were performed using two constitutive models, linear elastic perfectly plastic model (Mohr Coulomb model) and non-linear stress-strain constitutive model (Hardening Soil model).

\section{Constitutive Models}

The Mohr Coulomb model is a linear elastic perfectly plastic model with Mohr-Coulomb failure criterion.The model requires five input parameters namely Young's modulus $(E)$, Poission's ratio $(v)$, cohesion (c), friction angle $(\phi)$ and dilatancy angle $(\psi)$.

The hardening soil model is an advanced model applied for all types of soils and is based on shear and compression hardening. This model supersedes the hyperbolic model of Duncan \& Chang (1970) by using the theory of plasticity rather than the theory of elasticity and by including soil dilatancy and yield cap (Schanz et al., 1999). In contrast to Mohr-Coulomb model, the yield surface of a hardening plasticity model is not fixed in principal stress space but it can expand due to plastic straining (Brinkgreve et al., 2010).

The hyperbolic relationships for standard drained triaxial tests tend to yield curves, which can be described by:

$$
\begin{aligned}
& -\varepsilon_{1}=\frac{1}{E_{i}} \frac{q}{1-q / q_{a}} \text { for } q<q_{f} \\
& R_{f}=\frac{q_{f}}{q_{a}}
\end{aligned}
$$

where $E_{i}$ is the initial tangent Young's modulus, $q_{a}$ is the asymptotic value of the shear strength, $q$ is deviatoric stress, $\varepsilon_{1}$ is vertical strain, $q_{f}$ is the ultimate deviatoric stress derived from the Mohr-Coulomb failure criterion and $R_{f}$ is the failure ratio.

B. Moussai, Associate Professor, Member, ASCE USTHB University, Algiers, Algeria. e-mail: bmoussai@yahoo.ca.

Submitted on May 9, 2013; Final Acceptance on September 24, 2013; Discussion open until April 30, 2014. 


$$
\begin{aligned}
& E_{i} \text { is related to } E_{50} \text { by: } \\
& E_{i}=\frac{2 E_{50}}{2-R_{f}}
\end{aligned}
$$

The confining stress dependent stiffness modulus for primary loading $\left(E_{50}\right)$, for unloading and reloading $\left(E_{u r}\right)$ and for oedometer stress-strain conditions $\left(E_{\text {oed }}\right)$ are given by the following equations:

$$
\begin{aligned}
& E_{50}=E_{50}^{r e f}\left(\frac{c \cos \varphi-\sigma_{3}^{\prime} \sin \varphi}{c \cos \varphi+p^{r e f} \sin \varphi}\right)^{m} \\
& E_{u r}=E_{u r}^{r e f}\left(\frac{c \cos \varphi-\sigma_{3}^{\prime} \sin \varphi}{c \cos \varphi+p^{r e f} \sin \varphi}\right)^{m} \\
& E_{\text {oed }}=E_{\text {oed }}^{r e f}\left(\frac{c \cos \varphi-\frac{\sigma_{3}^{\prime}}{K_{0}^{n c} \sin \varphi}}{c \cos \varphi+p^{r e f} \sin \varphi}\right)^{m}
\end{aligned}
$$

where $E_{50}^{r e f}, E_{u r}^{r e f}, E_{o e d}^{r e f}$ are reference stiffness modulus corresponding to the reference confining pressure $p^{\text {ref }}, m$ is the amount of stress dependency, $K_{0}^{n c}$ is the $K_{0}$ value for normal consolidation, $c$ and $\varphi$ are strength parameters.

The triaxial modulus controls the shear yield surface and the oedometer modulus controls the cap yield surface.

\section{Calibration Procedure of Rockfill Material Parameters}

The finite element method is a useful tool, widely used in recent years to analyze the concrete face rockfill dams behaviour, but the accuracy of the finite element analysis depends on the selection of appropriate constitutive models and material parameters. The selection of the strength and stiffness parameters for dam materials needs much experience and engineering judgment, especially for rockfill materials. The rockfill testing data are usually limited or of low quality due to the large size of the rockfill elements which is difficult to test using conventional experimental equipments. Therefore, the parameters of rockfill materials used in the FEM analysis are often adopted from published data for similar materials.

The material stiffness modulus is essential for dam deformation prediction and the range of this parameter is very large, which make its estimation very approximate compared to other model parameters. In this study, the stiffness parameters of the rockfill materials are back analyzed based on the available crest monitoring data as follow:

- The Young's modulus ( $E$ ) of the MC model is calibrated by minimizing the deviation between the field observation and numerically computed results. The stiffness modulus obtained corresponds to the secant Young's modulus $E_{50}$. Loupasakis et al. (2009) evaluated the
Mohr Coulomb model for rockfill shell materials taken from an embankment dam and concluded that, the model theoretical curves that best match the triaxial experimental curves, are those having the secant stiffness modulus values $E_{50}$.

- The stiffness modulus $E_{50}^{\text {ref }}$ used in HS model is then evaluated based on the stiffness modulus $E_{50}$ obtained from MC model using the Eq. 4. This stiffness modulus can also be estimated using the expression:

$$
E_{50}^{r e f}=50\left(2-R_{f}\right) K
$$

This expression was derived from the combination of Eq. 3 and Janbu (1963) equation $E_{i}=K P_{a}\left(\sigma_{3}^{\prime} / P_{a}\right)^{n}$, where $K$ is the modulus number, $P_{a}$ is the atmospheric pressure, $\sigma_{3}^{\prime}$ is the minor principal stress and $n$ is the modulus exponent.

- $E_{u r}^{r e f}$ is set equal to 3 times $E_{50}^{r e f}$ as suggested in Plaxis manual and the oedometer stiffness parameter $E_{\text {oed }}^{\text {ref }}$ is then optimized by back analysis.

\section{El-Agrem Dam Characteristics}

The El-Agrem concrete face rockfill dam as shown in Fig. 1a, is located $15 \mathrm{~km}$ south - east of Jijel city (Algeria). The dam reservoir can store approximately 35 million cubic meters of water and provides drinking water to the surrounding region.

The dam is $64 \mathrm{~m}$ high and $395 \mathrm{~m}$ long with a crest width of $10 \mathrm{~m}$. The embankment volume is $1.6 \times 10^{6} \mathrm{~m}^{3}$ and consists of two zones of granitic rockfill materials as shown in Fig. 1b. Zone E1 comprises the majority of the embankment section with a maximum particle size of $0.6 \mathrm{~m}$ and compacted in layers of $0.8 \mathrm{~m}$ thick. Zone E2 is a $1 \mathrm{~m}$ thick transition zone consists of smaller-size rock, provided between the concrete face slab and the rockfill embankment.

The rockfill is compacted to a high density in order to minimize deformations and concrete slab cracks and leakage. The upstream and downstream slopes of the dam were established at $1.7 \mathrm{H}: 1 \mathrm{~V}$.

The concrete slab on the upstream side, provides the watertightness of the dam above the ground together with the perimetric joints and the plinth. The concrete slab has a total area of $31000 \mathrm{~m}^{2}$ with a variable thickness of $0.5 \mathrm{~m}$ at the base and $0.35 \mathrm{~m}$ at the top of the dam. The dam foundation consists of granite gneiss rock on the right bank and of marly rock on the left bank.

The dam embankment was almost completed in October 1993 (the embankment level reached was $140.5 \mathrm{~m}$ ), after that the construction activities were stopped for economic raisons. Construction activities resumed during the year 1999 and the embankment was raised to its final level $143 \mathrm{~m}$. The face slab was concreted during the year 2000, about 7 years after the end of embankment construction. 


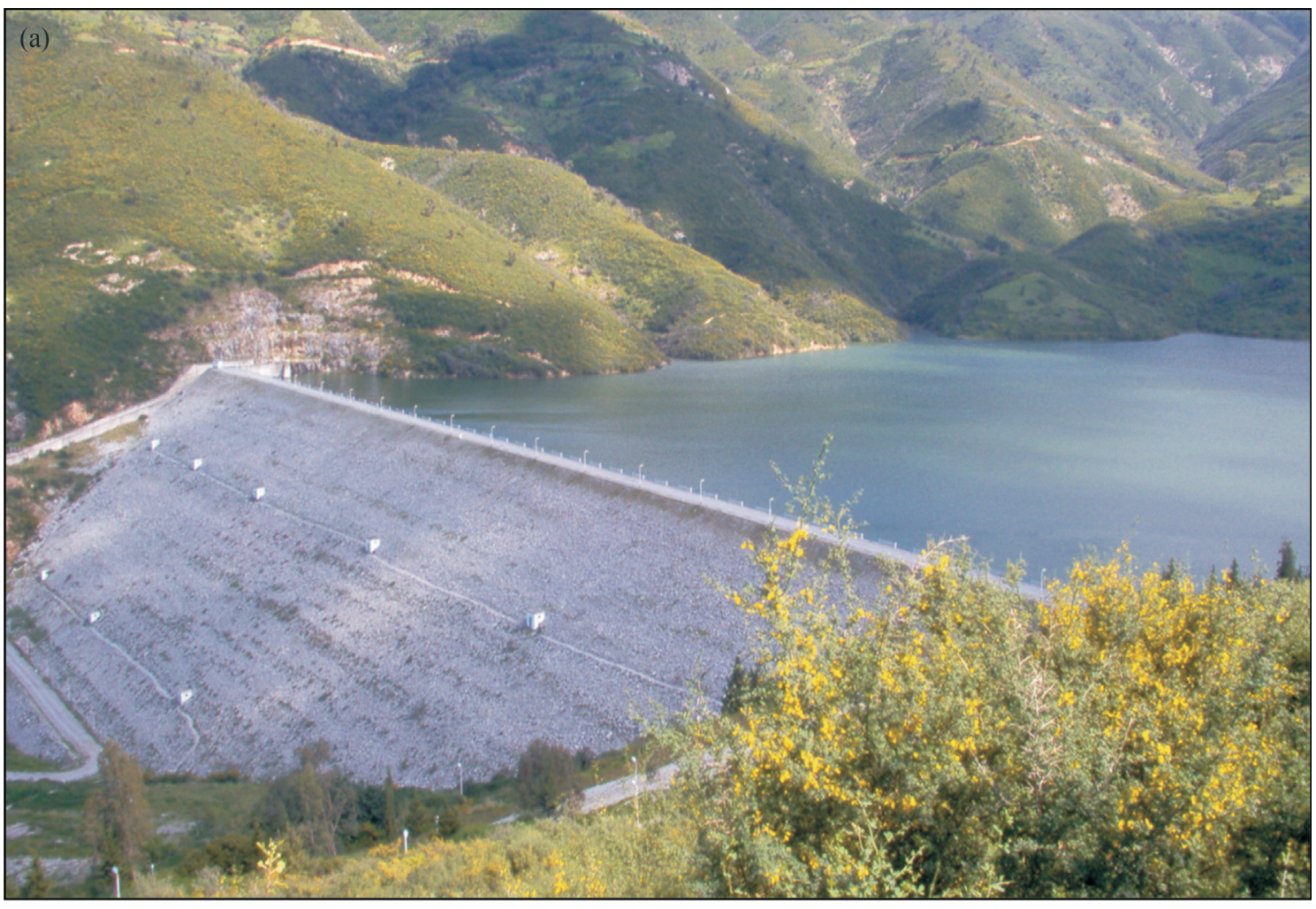

(b)

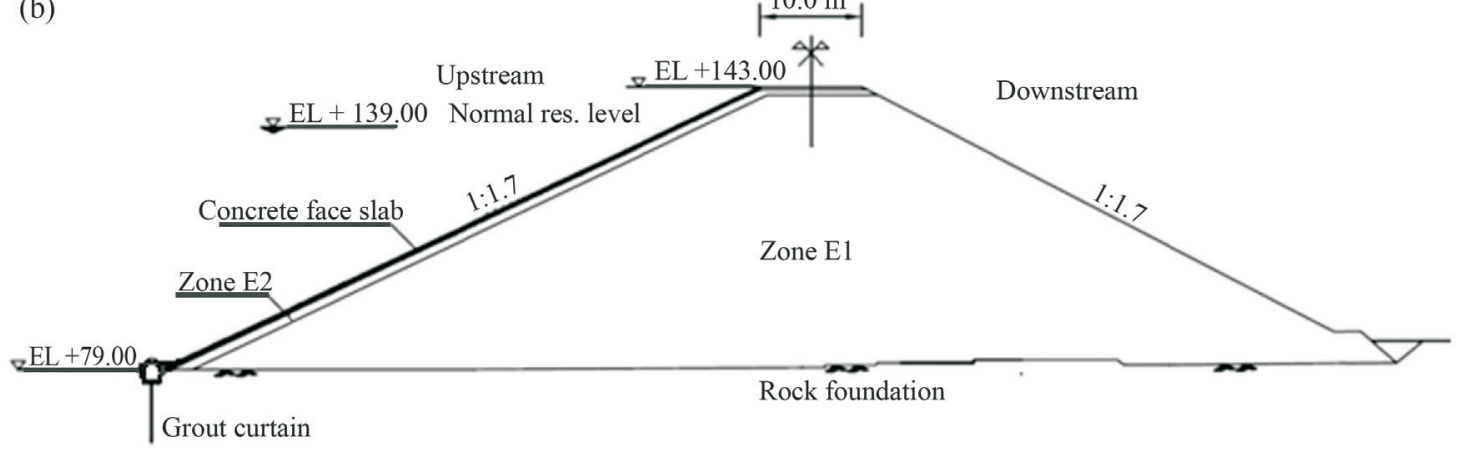

Figure 1 - a: General view of El-Agrem concrete face rockfill dam. b: Typical cross-section of El-Agrem concrete face rockfill dam.

Reservoir filling was started in 17 February 2001 (about three months after the completion of the face slab in November 2000) and the water level reached $99.21 \mathrm{~m}$ in 26 January 2002 and stabilized at this level until October 2002. From this date, the water level continued to increase and reached the normal pool level of $139 \mathrm{~m}$ in April 2003. Figure 2 shows the reservoir water level with respect to time.

The instrumentation system installed for monitoring the dam behavior includes geodetic monitoring system, inclinometers (no longer work), piezometers and flow measurement weir. The available geodetic monitoring data shows that the maximum crest settlement is about $0.035 \mathrm{~m}$. This value was obtained during the period from February 2001, which corresponds to the beginning of reservoir filling (that is more than 7 years after embankment construction and 3 months after concrete slab completion) to

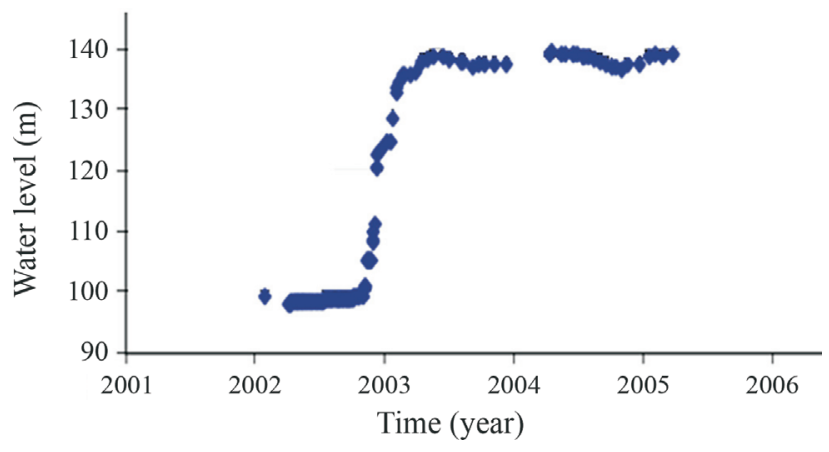

Figure 2 - Reservoir water level with respect to time.

September 2004 (that is 17 months after the end of the first reservoir filling).

The numerical study was conducted on the maximum cross - section of the dam resting on rock foundation using 
Table 1 - Rockfill parameters.

\begin{tabular}{|c|c|c|c|c|}
\hline Layer & Zone E1 & Zone E2 & Zone E1 & Zone E2 \\
\hline Model & Hardening Soil & Hardening Soil & Mohr Coulomb & Mohr Coulomb \\
\hline Unit weight: $\gamma / \gamma_{\text {sat }}\left(\mathrm{kN} / \mathrm{m}^{3}\right)$ & $19.5 / 20.5$ & $20 / 21$ & $19.5 / 20.5$ & $20 / 21$ \\
\hline Cohesion: c' (kPa) & 0 & 0 & 0 & 0 \\
\hline Friction angle: $\phi{ }^{\circ}$ & 45 & 42 & 45 & 42 \\
\hline Dilatancy angle $\psi^{\circ}$ & 15 & 12 & 15 & 12 \\
\hline Poisson's ratio: $v$ & - & - & 0.15 & 0.15 \\
\hline Young's modulus: $E(\mathrm{MPa})$ & - & - & $34 *$ & 80 \\
\hline Stiffness modulus: $E_{50}^{r e f}(\mathrm{MPa})$ & $29 *$ & 80 & - & - \\
\hline Stiffness modulus: $E_{\text {oed }}^{\text {ref }}(\mathrm{MPa})$ & $21 *$ & 80 & - & - \\
\hline Stiffness modulus: $E_{u r}^{r e f}(\mathrm{MPa})$ & 87 & 240 & - & - \\
\hline Poisson's ratio: $v_{u r}$ & 0.2 & 0.2 & - & - \\
\hline Stress dependent stiffness: $m$ & 0.25 & 0.25 & - & - \\
\hline Failure ratio: $R_{f}$ & 0.75 & 0.75 & - & - \\
\hline
\end{tabular}

*Obtained by back analysis.

Plaxis 2D-2010 software. The embankment was modelled using fifteen noded plane strain elements. Figure 3 shows the finite element model having 2228 elements and 18217 nodes.

The deformation of the dam foundation is considered negligible; therefore the model sets fixed displacements along the dam base in contact with the rock foundation. Furthermore, the dam is located in a wide valley (crest length / dam height equals to 6.1), thus three dimensional effect is negligible.

The concrete slab is modelled as linear elastic with Young's modulus equals to $30000 \mathrm{MPa}$ and Poisson ratio equals to 0.2. Rockfill materials are modelled with Mohr Coulomb and Hardening Soil models. Table 1 lists the parameters of the dam materials used in the numerical analysis. The dilation angle was estimated by the relation $\psi=\phi-$ 30 (Bolton, 1986).
The water pressure was applied as a triangular load distribution acting perpendicular to the face slab.

\section{Results and Discussion}

Only the stiffness parameters for the main rockfill zone $\left(E_{1}\right)$ were optimized by back analysis based on the available monitoring data while other parameters remained the same. The estimated values of the remainder models (MC and HS models) input parameters based on published data for similar materials are judged to be more accurate than stiffness parameters. The transition zone material $\left(\mathrm{E}_{2}\right)$ beneath the concrete face has no significant effect on the prediction of the dam deformation.

The Young's modulus for the main rockfill zone $\left(\mathrm{E}_{1}\right)$ used in MC model was calibrated based on the available measured crest settlement in situ $(35 \mathrm{~mm})$ and the best result was obtained when $E=34 \mathrm{MPa}$. This value agrees well

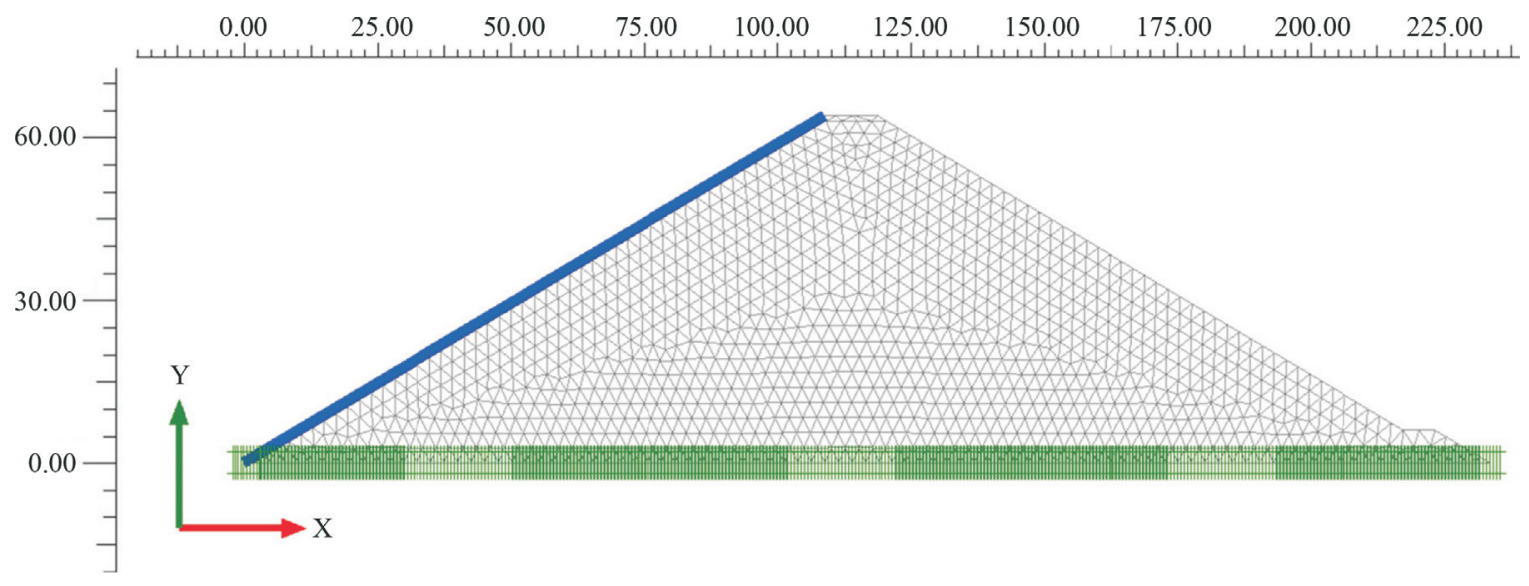

Figure 3 - Two dimensional finite element model. 
with the stiffness modulus of Xingo dam rockfill material measured at the end of construction ( $E=30$ to $39 \mathrm{MPa})$. This granite gneiss rockfill material has a maximum particle size of $650 \mathrm{~mm}$ and compacted in layers of $1 \mathrm{~m}$ thick (Pinto \& Marques, 1998).

Using Eq. 4 with $E_{50}=E=34 \mathrm{MPa}, m=0.25$ and an average confining pressure of the dam embankment of about $190 \mathrm{kPa}$, the computed $E_{50}^{\text {ref }}$ value used in HS model was found equals to $29 \mathrm{MPa}$. This value can be verified by introducing it into the Eq. 7 and calculating the number $\mathrm{K}$ used in hyperbolic model (Duncan \& Chang, 1970). This number was found equals to 464 , which agree with the typical values given by many authors for this parameter such as Duncan et al., 1980; Saboya et al., 1993; Liu et al., 2002; Massiera et al., 2006.

The oedometric stiffness modulus $E_{\text {oed }}^{r e f}$ is then back analyzed based on the available measured crest settlement in situ $(35 \mathrm{~mm})$ and the best results was obtained with $E_{\text {oed }}^{\text {ref }}=21 \mathrm{kPa}$, i.e., $E_{\text {oed }}^{\text {ref }}=0.72 E_{50}^{\text {ref }}$. This result agrees fairly well with that obtained by Pramthawee et al. (2011) for a concrete face rockfill dam main rockfill material with a maximum particle size of $800 \mathrm{~mm}\left(E_{\text {oed }}^{r e f}=0.8 E_{50}^{r e f}\right)$.

Figure 4 shows the variation of the total displacement with respect to dam height for the concrete slab, the downstream face and along the dam axis at the end of reservoir filling (water level at $139 \mathrm{~m}$ ). This figure indicates that, the maximum displacement of the concrete slab obtained using $\mathrm{MC}$ model is $0.26 \mathrm{~m}$ and takes place at a point about $44 \%$ of the dam height whereas HS model gives a maximum displacement of the concrete slab of $0.23 \mathrm{~m}$ and takes place at a point about $38 \%$ of the dam height.

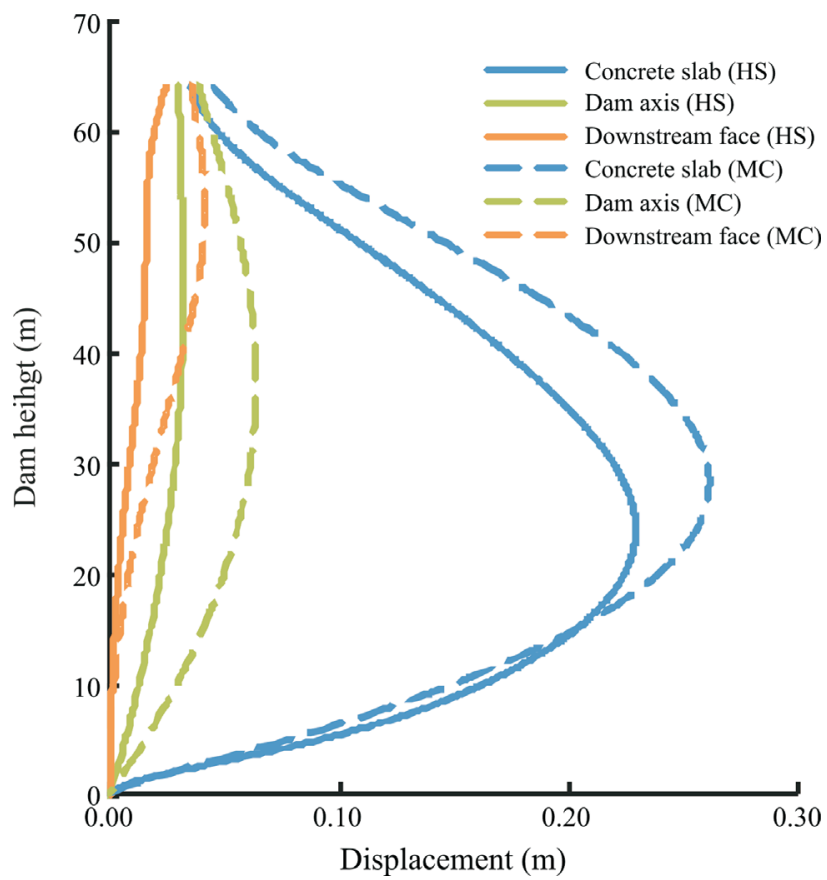

Figure 4 - Total displacement with respect to dam height at the end of reservoir filling.
The HS model resulted in concrete slab deformation less than MC model. This is attributable to the unloading behaviour of the upstream side of the dam where water load is applied, which is not taken into account by MC model.

Figure 5 indicates that the two models resulted in similar face slab deformation until the reservoir water depth reached about $40 \%$ of the dam height, after that the discrepancy between the two models increases with the increase of water depth. The maximum deformation normal to the face slab at the end of reservoir filling is less than $0.5 \%$ of the dam height and agreed with the results presented by Won \& Kim (2008).

Figure 6 shows that the crest settlement is not affected by water load when reservoir water depth is less than about $40 \% \mathrm{H}$ ( $\mathrm{H}$ is the dam height) for HS model and $60 \% \mathrm{H}$ for MC model. This can be explained by the fact that when the location of water load was far from the dam crest, no significant crest settlement was observed. With the increase of reservoir water level, the location of water load becomes

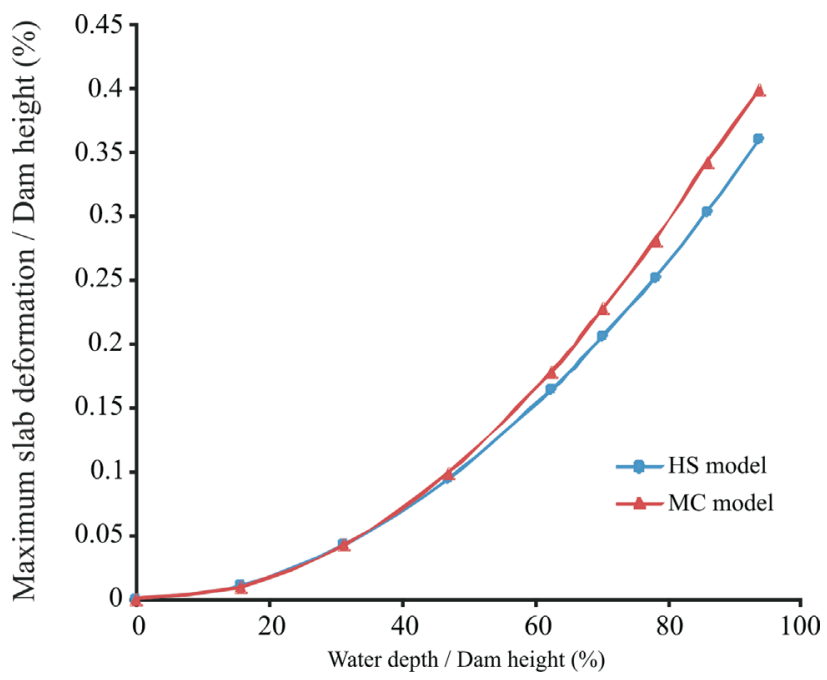

Figure 5 - Maximum deformation normal to the face slab vs. reservoir water depth expressed as a ratio of the dam height.

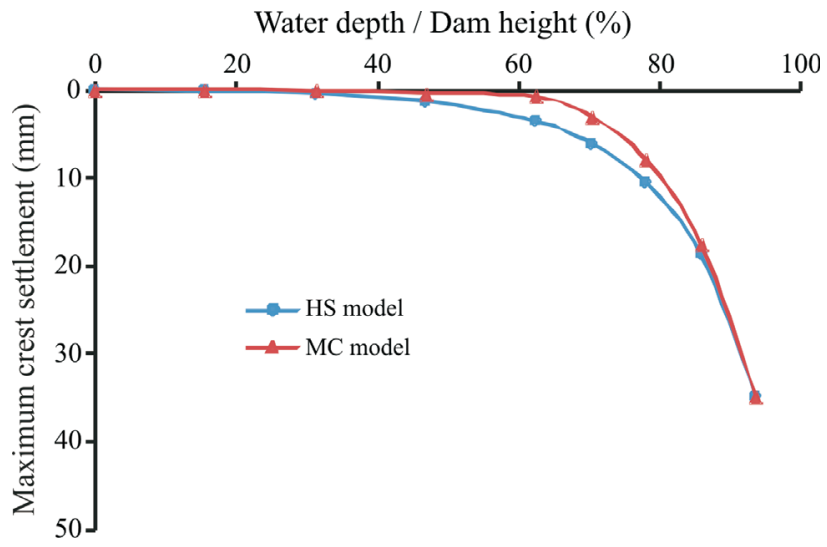

Figure 6 - Maximum crest settlement vs. reservoir water depth expressed as a ratio of the dam height. 
close to the crest, and then significant increase of crest settlement appears.

\section{Conclusions}

Since the reservoir filling in April 2003, the dam has performed well. The measured flow is less than $250 \mathrm{~L} / \mathrm{min}$. In the absence of monitoring data of the face slab deformation, numerical analysis was conducted to predict the face slab deflection. The parameters of the dam materials used in the numerical analysis were calibrated based on the available monitoring data of the crest settlement.

The numerical results indicate that the magnitude and location of the face slab maximum deflection are in good agreement with the results presented in the literature for concrete face rockfill dams (Hunter et al., 2003).

This study shows that from the measurement of the crest settlement which is easy to get from geodetic surveys, we can predict the face slab deformation using an advanced model (HS model) to simulate the behaviour of the rockfill materials. The HS model captures many important features of rockfill behaviour than MC model such as the nonlinearity of stress-strain relationship and stress dependency of stiffness.

\section{Acknowledgments}

The author is very grateful to the staff of ANBT (Agence Nationale des Barrages et Transferts) for providing the necessary data of the project.

\section{References}

Bolton, M.D. (1986) The strength and dilatancy of sands. Geotechnique, v. 36, p. 65-78.

Brinkgreve, R.B.J.; Swolfs, W.M. \& Engin, E. (eds) (2010) Plaxis 2D User's Manual. Plaxis 2010, Netherlands, 199 pp.

Duncan, J.M.; Byrne, P.; Wong, K.S. \& Babry, P. (1980) Strength, Stress-Strain and Bulk Modulus Parameters for Finite Element Analyses of Stresses and Movements in Soil Masses. Report No: UCB/GT/80-01, University of California, Berkeley, 70 pp.
Dancan, J.M. \& Chang, C.Y. (1970) Nonlinear analysis of stress and strain in soils J. of the soils mechanics and foundations division. ASCE, v. 96:SM5, p. 1629 - 1653.

Janbu, N. (1963) Soil compressibility as determined by oedometer and triaxial tests. Proceedings of European Conference on Soil Mechanics and Foundation Engineering, Wissbaden, Germany, pp. 19-25.

Hunter, G.; Glastonbury, J.; Ang, D. \& Fell, R. (2003) The performance of concrete face rockfill dams. UNICIV Report no. 413, The University of New South Wales, Sydney, 34 pp.

Liu, X.; Wu, X.; Xin, J. \& Tian, H. (2002) Three dimensional stress and displacement analysis of Yutiao concrete faced rockfill dam. Proc. of 2nd Int. Symp. on Flood Defense, Beijing, pp 1-10.

Loupasakis C.J. (2009) Evaluation of plasticity models ability to analyze typical earth dams soil materials. Geotech Geol Eng, v. 27. p. 71-80.

Massiéra, M.; Vautour, J.; Coulibaly, Y.; Hammamji, Y. \& Szostak-Chrzanowski, A. (2006) Prévisions des déformations et contraintes dans les barrages en enrochement avec masque amont béton. Proc. 2006 Annual General Conference of the Canadian Society for Civil Engineering, Calgary, Alberta, pp 1-10.

Pinto, N.L. \& Marques, P.L. (1998) Estimating the maximum face defletion in CFRDs. The International Journal on Hydropower \& Dams, Issue 6, pp. 28-30.

Pramthawee, P.; Jongpradist, P. \& Kongkitkul, W. (2011) Evaluation of hardening soil model on numerical simulation of behaviors of high rockfill dams. Songklanakarin J. Sci. Technol., v. 33. p. 325-334.

Saboya Jr., F. \& Byrne, P.M. (1993) Parameters for stress and deformation analysis of rockfill dams. Canadian Geotechnical Journal, v. 30, p. 690-701.

Schanz, T.; Vermeer, P.A. \& Bonnier, P.G. (1999) The hardening soil model: formulation and verification. Plaxis Symposium: Beyond 2000 in Computational Geothechnics. Amesterdam, Netherlands, pp. 281-296.

Won, M.S. \& Kim, S.Y. (2008) A case study on the post construction deformations of concrete face rockfill dams. Canadian Geotechnical Journal, v. 45. p. 845852. 


\title{
Numerical Analysis of Reinforcement Strains at Failure for Reinforced Embankments over Soft Soils
}

\author{
E.F. Ruiz, P.S. Hemsi, D.M. Vidal
}

\begin{abstract}
The use of geosynthetics as basal reinforcement in embankments constructed over soft soils provides technical and economic benefits by improving the stability of the structure, reducing horizontal displacements, homogenizing differential settlements, and reducing time of construction. An adequate design should include, however, more than routine limit equilibrium analyses, and should focus on understanding the soil-reinforcement interaction and mobilization of reinforcement strains during construction and with time, aspects that can be assessed with the use of finite elements simulations. This article presents the results of finite elements simulations for a hypothetical embankment over soft soil, applying the conceptual framework developed by Rowe \& Soderman (1987), Rowe et al. (1995) and Hinchberger \& Rowe (2003). Two approximate methods for obtaining the reinforcement allowable compatible strain at failure without the need for numerical simulations also are compared and discussed. The results in this article highlight the importance of assessing the mobilization of reinforcement strains during construction and taking into account soil-reinforcement interaction, given that reinforcement strains must be compatible with the soil system. An important implication, often overlooked in the past, is that the specification of geosynthetic materials for this application should be based on a minimum reinforcement stiffness modulus, i.e., the ultimate strength of the material may not suffice as a specification parameter.
\end{abstract}

Keywords: embankment on soft soil, geosynthetic, numerical analysis, reinforcement strain mobilization.

\section{Introduction}

Limit equilibrium methods have become widespread as a technique for assessing the undrained stability of reinforced embankments on soft soils (Jewel, 1982; Rowe, 1984). However, the application of this approach requires a certain assumption on the reinforcement strain at failure. Using the ultimate tensile strength of the geosynthetic reinforcement in limit equilibrium analyses (e.g., Michalowski, 1992) can lead to an overestimation of the short-term embankment stability, since reinforced embankments usually would have failed due to excessive displacements before the ultimate tensile strength of the reinforcement could be mobilized (Hinchberger \& Rowe, 2003). This article presents a case study of evaluation of undrained stability for a hypothetical geosynthetic-reinforced embankment on soft soil where the shear strength increases with depth. The simulation of the ultimate limit state response is carried out by using numerical modeling (Bergado et al., 1994, Palmeira et al., 1998) with the finite elements method, following the conceptual framework presented by Rowe \& Soderman (1987), Rowe et al. (1995) and Hinchberger \& Rowe (2003).

A simplified methodology to ensure adequate endof-construction (short term or undrained) stability by estimating the required minimum reinforcement stiffness modulus, $J_{\min }$, is also described. Attention is given to the mobilization of reinforcement strains under this condition.
Numerical results in terms of net embankment height, the development of contiguous plasticity of the soft soil, and allowable compatible strain are discussed. The objectives of this study are to develop comparisons between numerical results and two current approximate methods for obtaining reinforcement compatible strains, to develop a comparison between numerical results and traditional limit equilibrium results, and to discuss the implications of adopting an arbitrary reinforcement strain at failure on the stability of the embankment.

\section{Materials and Methods}

\subsection{Embankment geometry}

Figure 1 depicts the geometry adopted for this case study, representing a typical road embankment fill with design height, $h=2.30 \mathrm{~m}$, crest width, $b=28.8 \mathrm{~m}$, and side slopes $2(H): 1(V)$, constructed over a soft clay foundation of $D=8.0 \mathrm{~m}$ depth, with undrained shear strength at the surface, $S_{u}$, and a rate of increase of undrained shear strength with depth, $\rho_{c}$. An underlying permeable rigid stratum is assumed to occur below the soft clay layer.

\subsection{Mesh discretization and initial conditions}

Version 8.6 of the finite elements program PLAXIS (Plaxis, The Netherlands) (Brinkgreve \& Vermeer, 2004) was adopted in this study to simulate the construction and

E.F. Ruiz, MSc., Civil Engineer, Instituto Tecnológico de Aeronáutica, Praça Mal. Eduardo Gomes 50, São José dos Campos, SP, Brazil. e-mail: fernando@ huesker.com.br. P.S. Hemsi, Ph.D., Associate Professor, Instituto Tecnológico de Aeronáutica, Praça Mal. Eduardo Gomes 50, São José dos Campos, SP, Brazil. e-mail: paulosh@ ita.br. D.M. Vidal, DSc., Associate Professor, Instituto Tecnológico de Aeronáutica, Praça Mal. Eduardo Gomes 50, São José dos Campos, SP, Brazil. e-mail: delma@ ita.br. Submitted on May 22, 2013; Final Acceptance on August 9, 2013; Discussion open until April 30, 2014 


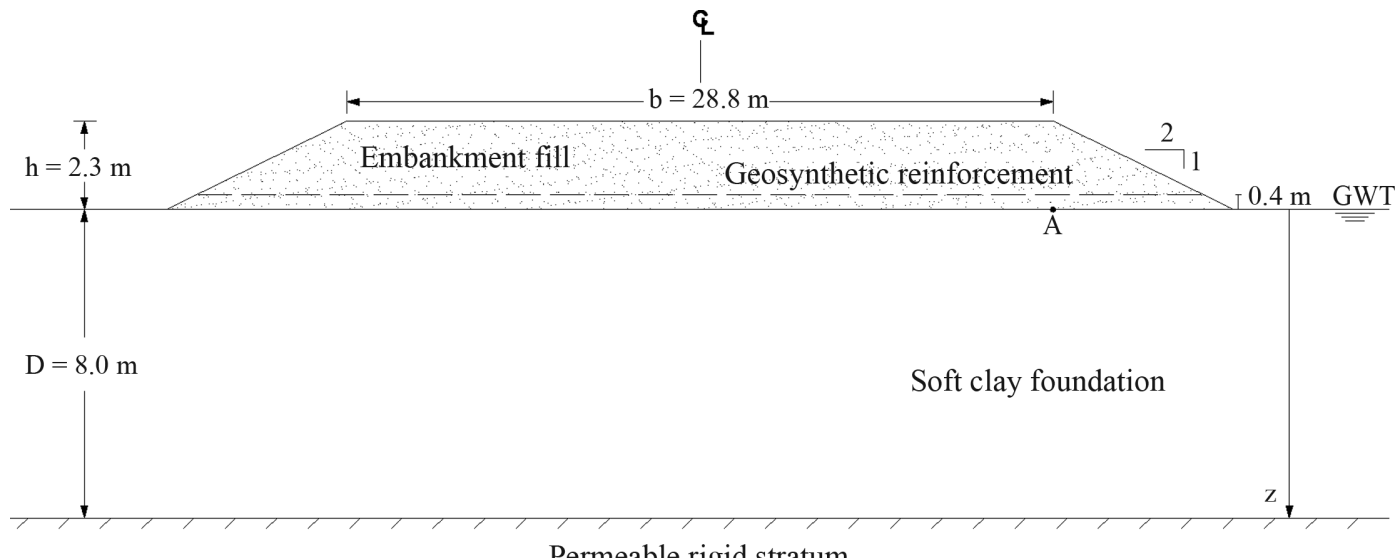

Permeable rigid stratum

Figure 1 - Adopted embankment cross-section and foundation soil stratigraphy for the case study.

short-term stability of the reinforced embankment. A small deformation and plane-strain finite elements analysis was conducted for the assumed embankment cross-section (Fig. 1).

A typical unstructured finite element mesh (Fig. 2) with fifteen-node triangular elements with fine global coarseness was selected to discretize the embankment fill and foundation soil. Five-node PLAXIS line elements with input elastic axial stiffness were used to model the geosynthetic reinforcement. Appropriate mesh size and boundary conditions (i.e., standard fixities option) were used to define the limits of the model and displacement restrictions around the cross-section.

Initial geostatic state of stresses was numerically calculated by adopting the $K_{o}$ procedure. Since a phreatic level was defined at ground surface, the hydrostatic initial porewater pressures were assessed automatically by the program. A rapid embankment construction was simulated by gradually turning on gravity on consecutive embankment layers in automatically defined thick lifts at a rate corresponding to instantaneous embankment construction (construction time is neglected). Due to the consideration of instantaneous construction, and short-term stability simulation, no soil water drainage was regarded in this case, i.e., the foundation soil was assumed to undergo undrained loading.

The model lateral extension was defined based on a PLAXIS recommendation that the model should extend laterally a distance (each side) equal to four times the total embankment width (in this case, 4 x $38 \mathrm{~m}=152 \mathrm{~m}$ to each side).

\subsection{Constitutive models and soil parameters}

The mechanical behavior of the foundation soft soil was modeled by using the Mohr-Coulomb constitutive model. Hence, it was assumed a soil with linear-elastic perfectly plastic stress-strain behavior, with fixed yield surface and non-associated plasticity rule. Anisotropy, progressive failure and more complex responses of the foundation soil were not modeled. The analyses were carried out in terms of total stresses, whereby the development of excess porewater pressures is not calculated by the program. The set of undrained soft clay parameters adopted for this study is presented in the top part of Table 1. The parameters were selected on the basis of typical values for Baixada Santista's (São Paulo state lowland) hollocenic alluvial normally to slightly over-consolidated soft clays (Massad, 2009), which are similar to parameters in other studies (e.g., Cappadoro et al., 2007, Moraes, 2002). Also, the parameter set is similar to that used by Hinchberger \& Rowe (2003).

A ratio $E_{u} / S_{u}=125$ was selected for estimating the undrained Young's modulus of the soft clay, in agreement with the range reported by Duncan \& Buchigani (1976), after a laboratory study carried out for a number of soft soils $\left(125<E_{u} / S_{u}<500\right)$. The lower-end value chosen corresponds to a critical condition in terms of deformability.

Purely frictional granular soil was assumed to model the embankment fill, i.e., the fill material was considered as being a pure sand. In order to represent the behavior of the sandy soil (i.e., stress-strain hyperbolic relation, stresslevel dependency of soil stiffness, shear and compression hardening), the Hardening soil model available in PLAXIS

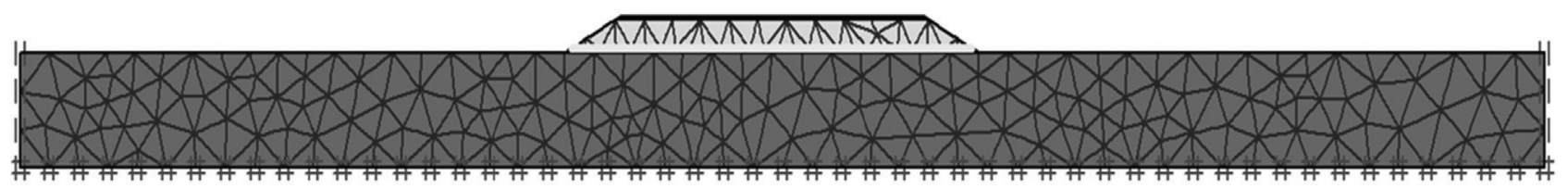

Figure 2 - Finite elements mesh based on triangular elements adopted for the numerical simulations. 
was chosen (Schanz et al., 1999, Brinkgreve \& Vermeer, 2004). The assumed properties for the soil representing the embankment fill are shown in the bottom part of Table 1.

\subsection{Interface parameters and reinforcement stiffness}

The considered position for the geosynthetic reinforcement was $0.40 \mathrm{~m}$ above the fill/soft soil interface. For modeling, the interface elements representing the fill/reinforcement interface were assumed to follow an elastic perfectly-plastic model (Mohr-Coulomb criterion), and the interface parameter $R_{\text {iner }}$ was chosen as being equal to 1.0 , meaning that the interface fill/reinforcement was assumed to exhibit the same shear strength as the fill soil immediately surrounding the interface. The shear resistance of the soft soil-fill interface was assumed to be equal to the un-

Table 1 - Geotechnical parameters assumed for the soft clay and the sand fill material.

\begin{tabular}{ll}
\hline Foundation soil & \\
\hline Undrained shear strength at surface $\left(S_{u 0}\right)$ & $5.0 \mathrm{kPa}$ \\
Rate of increase in undrained strength with & $1.50 \mathrm{kPa} / \mathrm{m}$ \\
depth, $\left(\rho_{c}\right)$ & \\
Total friction angle $(\varphi)$ & $0^{\circ}$ \\
Saturated unit weight $\left(\gamma_{\text {sat }}\right)$ & $15 \mathrm{kN} / \mathrm{m}^{3}$ \\
Undrained Poisson's ratio $\left(v_{u}\right)$ & 0.48 \\
Undrained Young's modulus $\left(E_{u}\right)$ & $E_{u} / S_{u}=125$ \\
Coefficient of lateral earth pressure at rest $\left(K_{0}^{\prime}\right)$ & 0.65 \\
\hline Embankment fill & \\
\hline Effective internal angle of friction $\left(\varphi^{\prime}\right)$ & $37^{\circ}$ \\
Effective cohesion intercept $\left(c^{\prime}\right)$ & $1.0 \mathrm{kPa}$ \\
Compacted unit weight $\left(\gamma_{b u l k}\right)$ & $18 \mathrm{kN} / \mathrm{m}^{3}$ \\
Poisson's ratio for unloading-reloading $\left(v_{u r}\right)$ & 0.20 \\
Secant triaxial stiffness modulus $\left(E_{50}\right)$ & $25,000 \mathrm{kPa}$ \\
Unloading-reloading stiffness modulus $\left(E_{u r}\right)$ & $75,000 \mathrm{kPa}$ \\
Oedometric stiffness modulus $\left(E_{o e d}\right)$ & $25,000 \mathrm{kPa}$ \\
Coefficient of lateral earth pressure at rest $\left(K_{0}{ }_{0}\right)$ & 0.47 \\
Power for stress-level dependency of stiffness $(m)$ & 0.50 \\
\hline & \\
\hline
\end{tabular}

drained shear strength of the foundation at the ground surface. The simplification $R_{\text {inter }}=1.0$ has been used in Rowe \& Soderman (1984), for example, and agrees with guidance from the PLAXIS manual.

The axial tensile stiffness $(J)$ of the slender bar elements used to model the elastic behavior of the geosynthetic reinforcement was varied in different simulation cases, i.e., from the value $J=0$ (unreinforced embankment) to varying $J$ values in different simulation cases, 300,800 , 500, 1000, 2000, 4000, 6000 and $8000 \mathrm{kN} / \mathrm{m}$.

\subsection{Definition of the ultimate limit state}

Ultimate limit states are associated with rotational and overall instability (as focused in this study), but also with other failure mechanisms, as depicted in Fig. 3 from the BS-8006 (2005).

These states are attained, for each specific mechanism, when disturbing forces or moments equal restoring forces or moments (available resistances). Margins and global factors of safety against attaining any limit state are provided by the use of partial load factors and partial material/resistance factors, producing design loads and design material parameters (BS-8006, 2005). For the case of reinforced embankments on soft foundation, Hinchberger \& Rowe (2003) and Rowe \& Taechakumthorn (2011) suggest the use of specific values for the partial factors, as shown in Table 2. Based on these partial factors, modified material parameters adopted to represent the ultimate limit state are also presented in Table 2 .

\section{Results and Discussion}

\subsection{Collapse height for the unreinforced embankment, $\mathrm{H}_{c}$}

By performing a conventional limit equilibrium analysis (slip circle, modified Bishop method) using the software GGU Stability (Civilserve GmbH, Germany), the collapse height for the embankment shown in Fig. 1 without reinforcement $(J=0)$ was estimated. In limit state design, the collapse height $H_{c}$ corresponds to the height at which the overturning moment is equal to the restoring moment for factored soil parameters (i.e., safety factor $=1.0$ ). The collapse height, $H_{c}$, for the unreinforced embankment was

Table 2 - Ultimate limit state design parameters considered for this study.

\begin{tabular}{|c|c|c|}
\hline Material parameters & Partial factors & Design values considered \\
\hline \multicolumn{3}{|l|}{ Foundation soil } \\
\hline Undrained shear strength at surface $-S_{u 0}=5.0 \mathrm{kPa}$ & $f_{c}=1.3$ & $S_{u 0} *=3.85 \mathrm{kPa}$ \\
\hline Rate of increase in undr. strength w/ depth $-\rho_{c}=1.50 \mathrm{kPa} / \mathrm{m}$ & $f_{c}=1.3$ & $\rho_{c}^{*}=1.15 \mathrm{kPa} / \mathrm{m}$ \\
\hline \multicolumn{3}{|l|}{ Embankment fill } \\
\hline Effective internal angle of friction $-\varphi^{\prime}=37^{\circ}$ & $f_{\phi}=1.2$ & $\varphi^{\prime} *=32^{\circ}$ \\
\hline Compacted unit weight $-\gamma_{b u l k}=18 \mathrm{kN} / \mathrm{m}^{3}$ & $f_{\gamma}=1.1$ & $\gamma_{\text {bulk }} *=20 \mathrm{kN} / \mathrm{m}^{3}$ \\
\hline
\end{tabular}




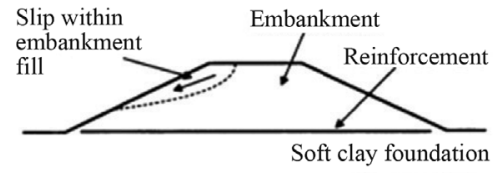

a) Local stability

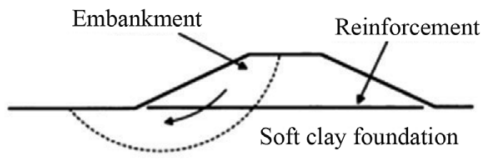

b) Rotational stability

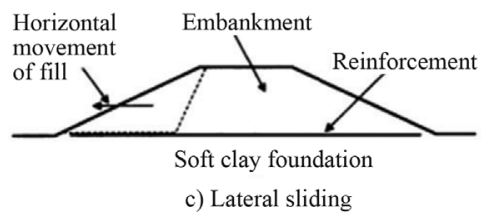

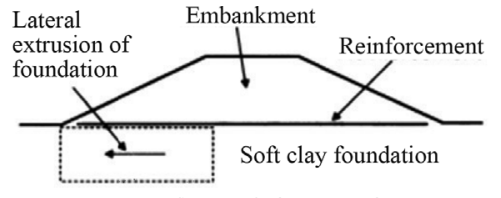

d) Foundation extrusion

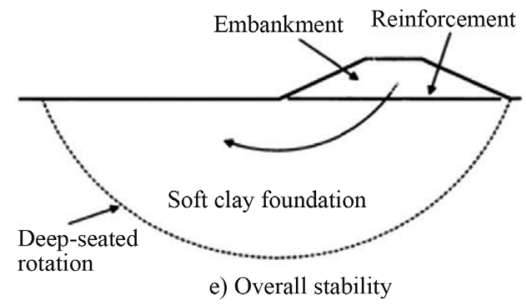

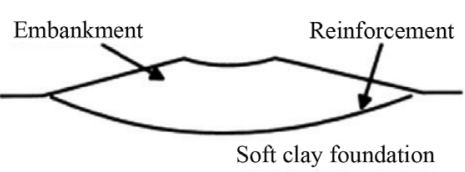

a) Reinforcement strain

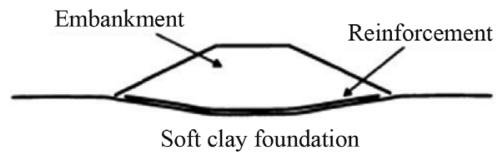

b) Foundation settlement

Figure 3 - Ultimate limit states for embankments on soft soils (modified from BS-8006, 2005).

found to be equal to $1.4 \mathrm{~m}$. Since $H_{c}$ is less than the required design height, $h=2.3 \mathrm{~m}$, the use of a geosynthetic reinforcement is necessary in order to attain the additional fill height.

Figure 4 shows the critical failure circle from limit equilibrium superimposed to the displacement vector field from a complementary finite elements simulation of the same case.

\subsection{Collapse height for the perfectly reinforced em- bankment, $\boldsymbol{H}_{m}$}

The theoretical maximum possible fill thickness for this case study, obtained for a perfectly-reinforced embankment (heavy reinforcement), $H_{m}$, was estimated based on plasticity limit analysis considering the problem of a rigid plate on soft foundation, as described by Almeida (1996). This maximum collapse height was estimated as being $H_{m}=2.50 \mathrm{~m}$, for factored soil parameters. Since the required design height $(h=2.30 \mathrm{~m})$ does not exceed $H_{m}$ $\left(h<H_{m}\right)$, the design embankment height may be achieved using embankment reinforcement. If $h>H_{m}$, soft soil im- provement (e.g., cement injection and mixing) or the use of a structural solution would be warranted.

\subsection{Net embankment height and reinforcement allow- able compatible strain}

The instantaneous construction of the embankment was numerically simulated until collapse using the ultimate limit state design parameters in Table 2 . The undrained stability of an embankment can be analyzed in terms of failure height of the structure. The failure height of a reinforced embankment can be defined as the height of fill at which the net embankment height ceases to increase. The net embankment height is defined as the fill thickness minus the vertical displacement caused by the undrained settlement of the soil (i.e., fill height above the original ground surface). Thus, the failure height was obtained by plotting the net embankment height (i.e., applied fill thickness minus the undrained vertical displacement of point " $A$ " indicated in Fig. 1) vs. the total applied fill thickness. Figure 5 illustrates this plot, for the case study with a reinforcement $J=500 \mathrm{kN} / \mathrm{m}$.

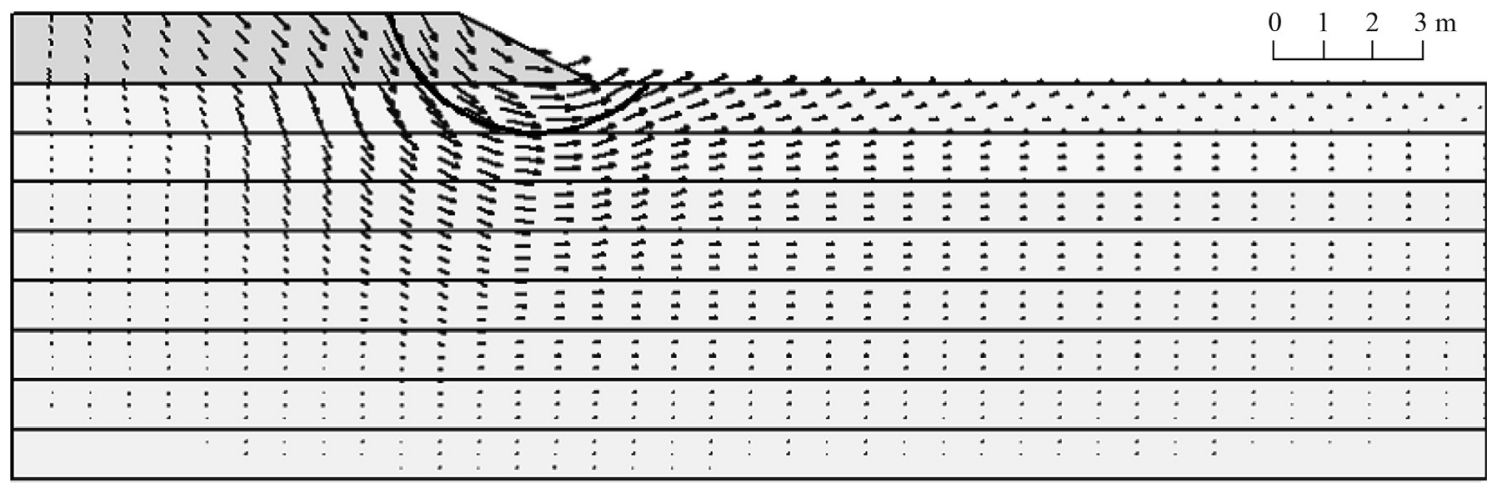

Figure 4 - Assessment of the embankment collapse height without reinforcement, $H_{c}=1.40 \mathrm{~m}$, using limit equilibrium, superimposed to finite elements vectors. 


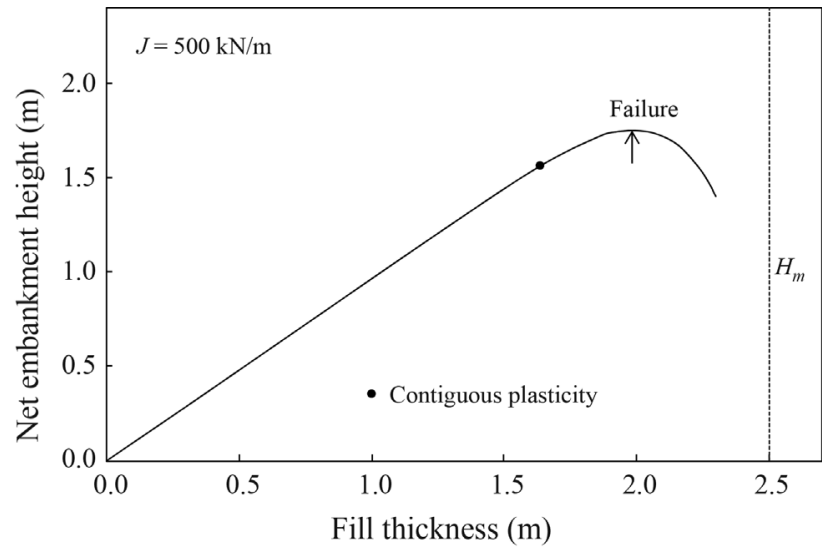

Figure 5 - Maximum net embankment height obtained by finite elements simulation of the case study with $J=500 \mathrm{kN} / \mathrm{m}$.

As can be observed, the failure of the reinforced embankment due to excessive subsidence occurs at a fill thickness of about $1.98 \mathrm{~m}$. Therefore, any additional fill placement beyond a thickness of $1.98 \mathrm{~m}$ will reduce the embankment performance without increasing the height of embankment fill above the original soft soil. For this reason, it is important to define the failure thickness of a reinforced embankment as the fill thickness corresponding to the maximum net embankment height. The degradation of the embankment performance can be explained as additional submersion of fill material into a plastic-state soft clay, with additional shearing and lateral movement (see Fig. 6). Rowe \& Soderman (1987) defined contiguous plasticity as the point where there is general plastic failure within the soft soil in the region of a potential collapse mechanism (i.e., the shear strength of the soil is fully mobilized along the potential collapse surface). For the unreinforced embankment, the maximum net fill height occurs at the onset of this limit. However, as indicated in Fig. 5 (see the contiguous plasticity point), for a reinforced embankment, the development of contiguous plasticity is only the first step towards failure, since some fill thickness can be supported by the reinforcement. Bergado et al. (2002) refer to the point of contiguous plasticity as primary failure. In Fig. 5, the fill thickness at the point of contiguous plasticity is $\sim 1.64 \mathrm{~m}$, which, in agreement with Bergado et al. (2002), occurs prior to failure due to excessive vertical displacement and complete degradation of performance.

In this study, the simulated zones of soft-soil plastification beneath the embankment were observed, particularly near the state of contiguous plasticity. The different configurations of soft-soil plasticity zones depend on the rigidities of both embankment/reinforcement and foundation soil, and the constitutive models (hardening soil for the embankment, in particular). For the condition of contiguous plasticity indicated in Fig. 5, the plastic zone within the foundation soil has become continuous resulting in an initial development of a potential failure plane.
Figure 6 shows the results of the numerical simulation in terms of the maximum mobilized reinforcement strains during embankment construction. At embankment failure, i.e., a fill thickness of $1.98 \mathrm{~m}$ (Fig. 5), the maximum reinforcement strain $\left(\varepsilon_{f}\right)$ is equal to $3.54 \%$ for $J=500 \mathrm{kN} / \mathrm{m}$. The works of Rowe \& Soderman (1987), Rowe et al. (1995) and Hinchberger \& Rowe (2003) provided a quantifiable framework for recognizing the fact that in most cases (as shown here for the case study) the mobilized reinforcement strains are still low (e.g., 3.54\%) when the soil mass is already reaching failure. Several reinforcement geosynthetics have a similar stiffness, but significantly higher tensile strains at failure ( $>3.54 \%$ ), meaning that these reinforcements would not be fully loaded in the field before significant degradation of the soil.

Significant strains in the reinforcement only begin to accumulate after a significant plastification of the foundation soil, as indicated by the abrupt change in the slope of the curve of Fig. 6 after the point of contiguous plasticity. Beyond the point of contiguous plasticity of the soil, the reinforcement becomes the element that prevents collapse from taking place. Conversely, for low levels of embankment loading and soft soil in an elastic state, reinforcement strains are extremely small. The strains developed in the reinforcement for a given embankment height will largely depend on the height of embankment relative to that height at which contiguous plasticity occurs (Rowe \& Soderman, 1987).

Past the maximum embankment height (failure, in Fig. 6), the placement of additional fill thicknesses will increase the plastification and degradation of the foundation soil, and be supported by additional elongation of the reinforcement, until a point of reinforcement collapse $(9.76 \%$, collapse point in Fig. 6).

The analyses were repeated for embankments with different reinforcement stiffness moduli, in three simulated cases, for $J=500,1000$ and $1500 \mathrm{kN} / \mathrm{m}$, as shown in Fig. 7 . From these results, the maximum net embankment height was found to increase with increasing the reinforcement

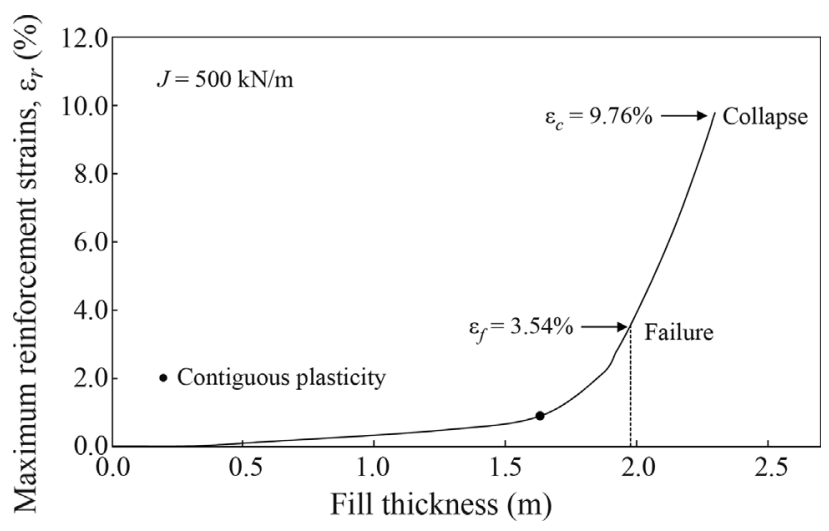

Figure 6 - Mobilized maximum reinforcement strains during embankment construction obtained by finite elements simulation of the case study with $J=500 \mathrm{kN} / \mathrm{m}$. 


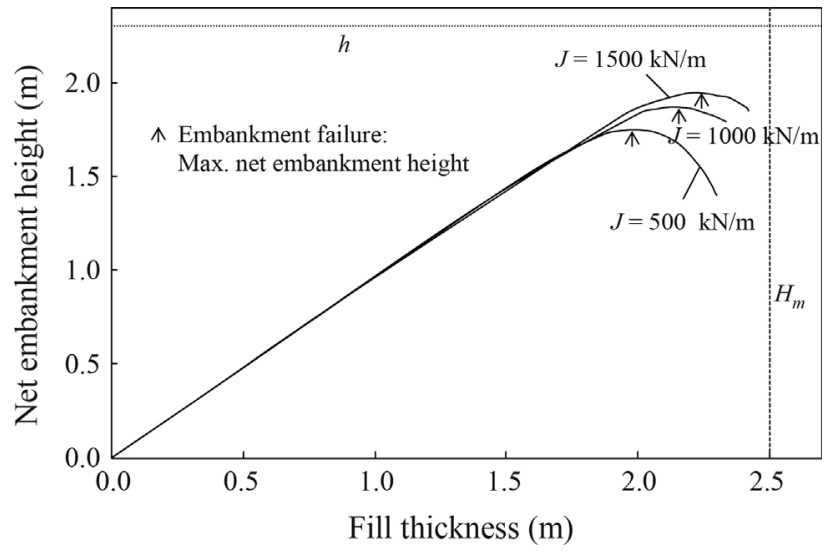

Figure 7 - Effect of varying $J$ from $500 \mathrm{kN} / \mathrm{m}$ to 1000 and $1500 \mathrm{kN} / \mathrm{m}$ on the maximum net embankment height obtained by finite elements simulation of the case study.

stiffness modulus, for a given soil profile, with maximum net embankment heights of $1.98 \mathrm{~m}, 2.33 \mathrm{~m}$, and $2.41 \mathrm{~m}$, for $J=500,1000$, and $1500 \mathrm{kN} / \mathrm{m}$, respectively. The effect of increasing $J$ on the increase in maximum net embankment height diminishes with the magnitude of $J$, which is compatible with the existence of an $H_{m}$.

In addition, Fig. 8 presents the results in terms of mobilized reinforcement strains during embankment construction considering the three different reinforcement stiffness moduli, $J=500,1000$ and $1500 \mathrm{kN} / \mathrm{m}$, for the simulated case. From the results, it is possible to observe that for the soft soil before contiguous plasticity the embankment strains are low and independent of reinforcement modulus. After contiguous plasticity, the reinforcement stiffness modulus becomes important, and different net embankment heights at failure are obtained for different values of $J$ (Fig. 7). As shown in Fig. 8, the mobilized reinforcement strains decrease slightly with increasing values of $J$, from 500 to $1500 \mathrm{kN} / \mathrm{m}$, for this case study. Hinchberger \& Rowe (2003) identify two different ranges of behavior, a first "under-reinforced" embankment range characterized

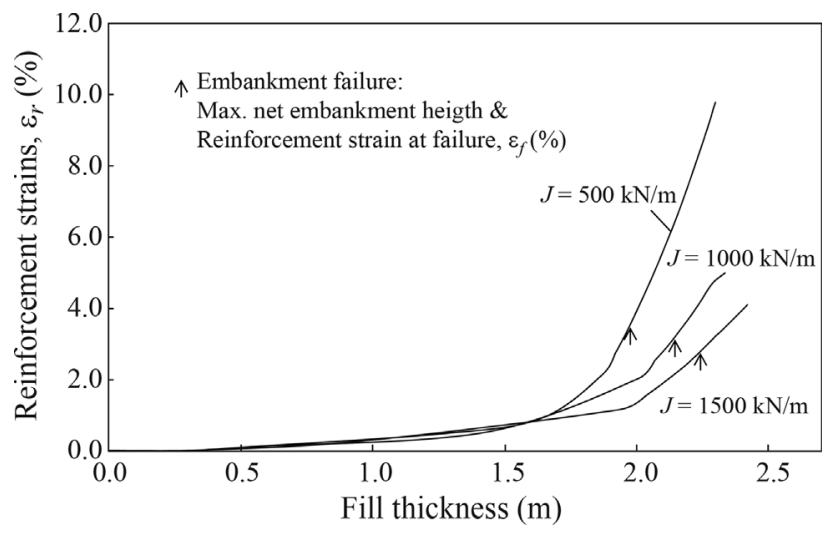

Figure 8 - Effect of varying $J$ from $500 \mathrm{kN} / \mathrm{m}$ to 1000 and $1500 \mathrm{kN} / \mathrm{m}$ on the mobilized reinforcement strains obtained by finite elements simulation of the case study. by mobilized reinforcement strains at failure (determined for the maximum net embankment height) that remain essentially constant for different values of $J$, and a second range of behavior characterized by reinforcement strains at failure that decrease with increasing reinforcement stiffness $(J)$, such that the mobilized reinforcement force $(F=J \times \varepsilon)$ approaches a constant value.

The results in Fig. 8 indicate that varying $J$ from 500 to $1500 \mathrm{kN} / \mathrm{m}$ includes both ranges of behavior, i.e., first "under-reinforced" behavior, and the second range of behavior. In order to better distinguish these two ranges, additional simulations were performed, extending the range in $J$ from 300 up to $8000 \mathrm{kN} / \mathrm{m}$. The obtained results are synthesized in Fig. 9. As expected, the maximum fill thicknesses at failure converge to the bearing capacity value given by plastic limit analysis. Based on the results, the range of "under-reinforced" embankment behavior was found to extend from $J=300$ to $1000 \mathrm{kN} / \mathrm{m}$, as indicated in Fig. 9 .

Hinchberger \& Rowe (2003) defined a reinforcement allowable compatible strain, $\varepsilon_{a}$, as being equal to the essentially constant strain occurring in the first range of behavior, i.e., under-reinforced embankment. Since the reinforcement strains in the first range are assumed to be constant, the allowable compatible strain for the embankment in this case study was calculated as being equal to the average value of the strains obtained for $J=300$ to $1000 \mathrm{kN} / \mathrm{m}$, shown in Table 3.

\subsection{Comparison with approximate methods}

Generally, finite elements analyses remain costly as routine design procedure, which warrants the convenience of analytical calculations and charts. Hinchberg \& Rowe (2003) introduced a chart for estimating the reinforcement allowable compatible strain simply, without requiring finite elements simulations to be performed.

For the unreinforced collapse height $H_{c}=1.40 \mathrm{~m}$, and factored rate of increase in undrained shear strength $\rho_{c}=1.15 \mathrm{kPa} / \mathrm{m}$, the allowable compatible strain for this

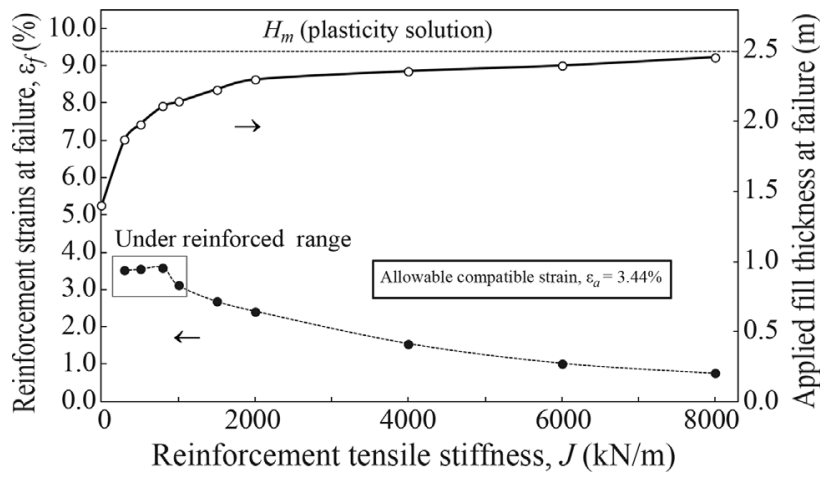

Figure 9 - Effect of varying $J$ from 300 to $8000 \mathrm{kN} / \mathrm{m}$ on the mobilized reinforcement strains at failure (closed circles, see lefthand side scale) and applied fill thicknesses at failure (open circles, see right-hand side scale) obtained by finite elements simulation of the case study. 
Table 3 - Calculation of a reinforcement allowable compatible strain for the embankment in this case study.

\begin{tabular}{lc}
\hline $\begin{array}{l}\text { Stiffness modulus ("un- } \\
\text { der-reinforced" range) } J\end{array}$ & $\begin{array}{c}\text { Reinforcement strain at failure } \\
(\mathrm{kN} / \mathrm{m})\end{array}$ \\
\hline 300 & $\varepsilon_{f}(\%)$ \\
500 & 3.51 \\
800 & 3.54 \\
1000 & 3.59 \\
\hline
\end{tabular}

Allowable compatible strain, $\varepsilon_{a}=3.44 \%$.

case study results equal to $3.9 \%$ using the chart depicted in Fig. 10.

Also, Futai (2010) proposed, on the basis of numerical simulations, analytical correlations for estimating the reinforcement allowable compatible strains at failure for different scenarios. This proposal was developed by considering a proportional variable for the undrained shear strength of the foundation soil as the main parameter $\left(\mathrm{Su}_{0}+7.5 \rho\right)$. The validation of the method was performed by comparing the calculated values and the measured strains of different instrumented embankments brought to failure.

For the factored soft-soil shear strength parameters in this study,

$$
S_{u 0}^{*}+7.5 \rho_{c}^{*}<16.2 \mathrm{kPa}
$$

and the correlation for allowable compatible strain to be used is (Futai 2010):

$$
\varepsilon_{a}=0.8 \frac{S_{u 0}^{*}+7.5 \rho_{c}^{*}}{9}
$$

which results in an estimated value of reinforcement allowable compatible strain of $2.2 \%$.

Thus, for this case study, estimation of the reinforcement allowable compatible strain using the simplified pro-

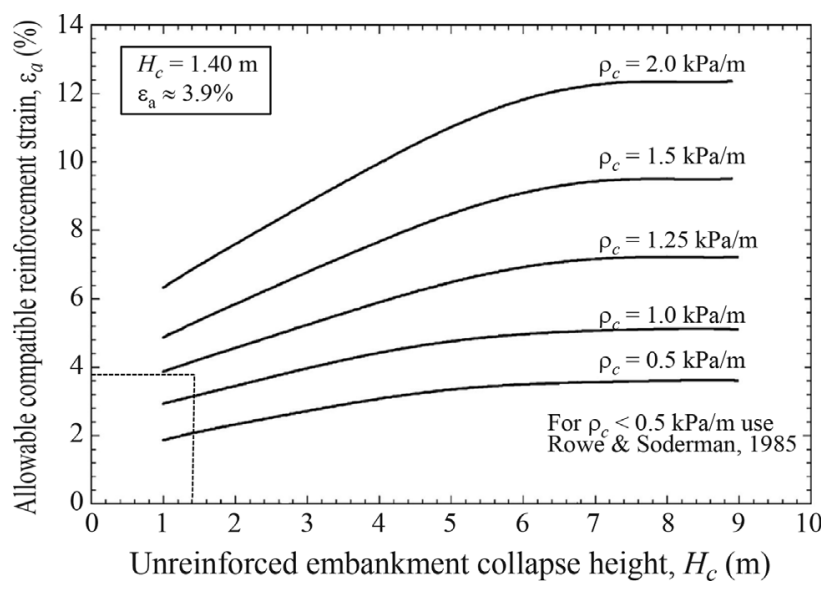

Figure 10 - Estimating the reinforcement allowable compatible strain for this case study using the chart by Hinchberger \& Rowe (2003). cedures resulted in either $15 \%$ overestimation (Hinchberg \& Rowe, 2003) or 35\% underestimation (Futai, 2010) with respect to the $\varepsilon_{a}$ evaluated based on numerical analyses, as shown in Table 4.

\subsection{Minimum secant reinforcement stiffness modulus}

The required reinforcement force, for the design fill thickness of $2.30 \mathrm{~m}$, can be evaluated using limit equilibrium for a factor of safety of 1.0 for factored soil parameters as being equal to $T_{r o}=50 \mathrm{kN} / \mathrm{m}$ (modified Bishop method, software $G G U$ Stability), as shown in Fig. 11.

Considering the reinforcement allowable compatible strain, $\varepsilon_{a}$, as being constant along the reinforcement length (i.e., the reinforcement as being uniformly pulled), it is possible to evaluate the minimum required secant reinforcement stiffness modulus for design, as follows:

$J_{\min }=\frac{\alpha_{r} T_{r o}}{\varepsilon_{a}}=1.15 \times 50 \mathrm{kK} / \mathrm{m} / 0.0344=1672 \mathrm{kN} / \mathrm{m}$

Adopting a reinforcement force correction factor, $\alpha_{r}=1.15$ (according to Hinchberger \& Rowe, 2003).

Thus, the reinforcement minimum required secant stiffness modulus results from the combination of results obtained from limit equilibrium analyses and finite elements analyses (or the approximate methods shown in 3.4). The geosynthetic reinforcement to be considered for the embankment in this case study must meet the requirements of minimum secant stiffness modulus of $1672 \mathrm{kN} / \mathrm{m}$ over a strain range of 0 to $3.44 \%$, and nominal ultimate strain greater than $3.44 \%$.

\subsection{Implications for design}

Often, the necessary reinforcement force $\left(T_{r o}\right)$ is known from limit equilibrium analyses but the magnitude of reinforcement strain is unknown. The fact that the reinforcement strain at which $T_{r o}$ is mobilized must be also compatible with the deformation of the soft soil, is sometimes disregarded. The requirement for geosynthetic reinforcement selection must be a minimum secant stiffness modulus, and not a minimum tensile strength. Assume that for the case study described in this article an arbitrary reinforcement strain of $10 \%$ was considered, without taking into account strain compatibility with the soil, for the $T_{r o}$ of $50 \mathrm{kN} / \mathrm{m}$ obtained from limit equilibrium for fill thickness

Table 4 - Comparison of reinforcement allowable compatible strain with approximated values obtained using two simplified procedures.

\begin{tabular}{lc}
\hline Approach & $\begin{array}{c}\text { Allowable compatible } \\
\text { strain, } \varepsilon_{a}(\%)\end{array}$ \\
\hline Finite Elements & 3.4 \\
Hinchberger \& Rowe (2003) & 3.9 \\
Futai (2010) & 2.2 \\
\hline
\end{tabular}




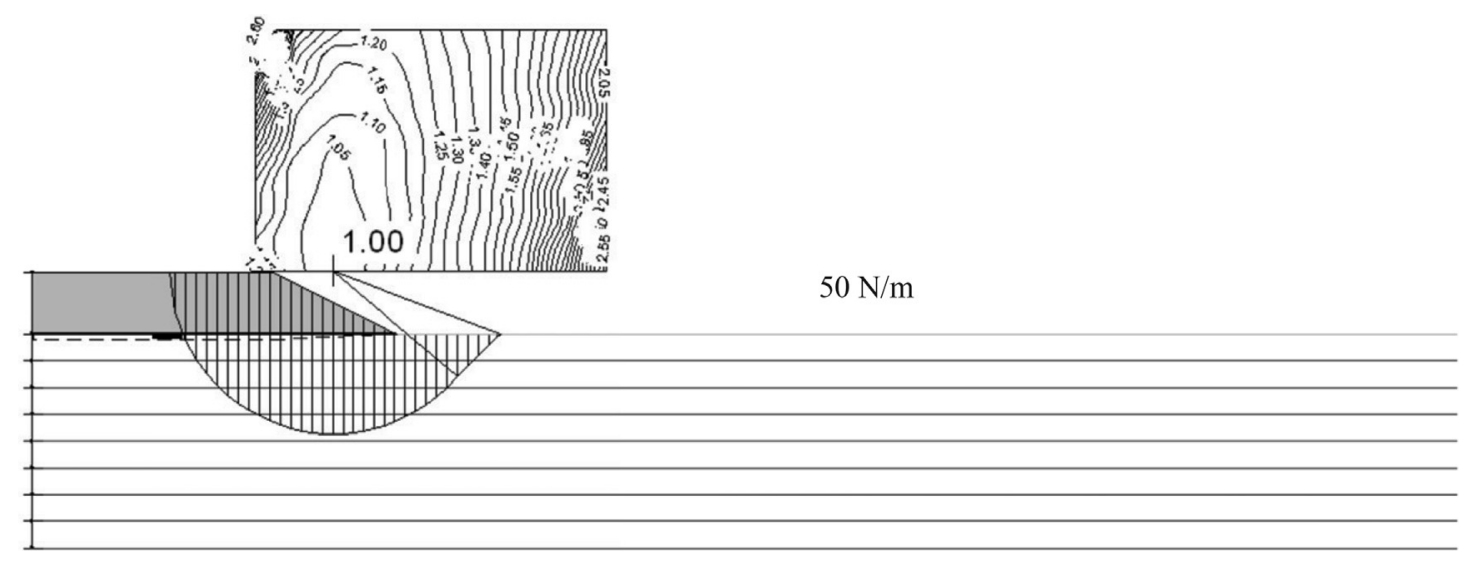

Figure 11 - Limit equilibrium stability analysis for factor of safety 1.0, allowing to estimate the required reinforcement force, $T_{r o}(G G U$ Stability).

Table 5 - Differential behavior between 'minimum' and 'arbitrary' reinforcement stiffness.

\begin{tabular}{lccc}
\hline Stiffness modulus, $J$ & $\begin{array}{c}\text { Applied fill thickness } \\
\text { at failure (FEM) }\end{array}$ & $\begin{array}{c}\text { Mobilized force } \\
\text { at failure (FEM), } T_{\text {mobf }}\end{array}$ & Global factor of safety (LE) \\
\hline$J_{\text {min }}=1672 \mathrm{kN} / \mathrm{m}$ & $2.28 \mathrm{~m}$ & $45.9 \mathrm{kN} / \mathrm{m}$ & 1.21 \\
$J_{\text {arbitrary }}=500 \mathrm{kN} / \mathrm{m}$ & $1.98 \mathrm{~m}$ & $17.7 \mathrm{kN} / \mathrm{m}$ & 1.02 \\
\hline
\end{tabular}

FEM: finite elements method.

LE: limit equilibrium.

of $2.30 \mathrm{~m}$. An arbitrary reinforcement stiffness modulus would be obtained, $500 \mathrm{kN} / \mathrm{m}$.

As shown in Table 5, finite elements analysis of the embankment with a reinforcement with $J=500 \mathrm{kN} / \mathrm{m}$ indicates a mobilized reinforcement force at failure of only $17.7 \mathrm{kN} / \mathrm{m}$. This force introduced into the limit equilibrium stability analysis results in an insufficient factor of safety (1.02).

Magnani et al. (2010) also described a similar type of behavior for the case study of a test embankment in Florianópolis, SC, Brazil, where the mobilized force in the reinforcement at failure was monitored by field instrumentation. The study verified that assuming a constant reinforcement force at failure and ignoring reinforcement strain may lead to an unconservative assessment of embankment stability.

\section{Conclusions}

Limit equilibrium analyses of the overall stability of reinforced embankments over soft soil can provide an estimate for a required reinforcement force for satisfactory factor of safety. However, an understanding of the soil-reinforcement interaction and mobilization of reinforcement strains during construction is critical for the correct definition of the geosynthetic reinforcement to employ. For a hypothetic embankment over soft soil considered in this study, the net embankment height, point of contiguous plasticity and reinforcement allowable compatible strain were studied following a previously defined theory. In addition, approximate methods for predicting the allowable compatible strain without the need for numerical simulations were verified, and one of the procedures overestimated the strain by $15 \%$, whereas the other underestimated the strain by $35 \%$. Finally, this article discussed the fact that the specification of geosynthetic materials for this application should be based on a minimum reinforcement stiffness modulus, instead of solely the ultimate strength of the material.

\section{References}

Almeida, M.S.S. (1996) Embankments on soft soils: from conception to performance evaluation. Ed. Universidade Federal do Rio de Janeiro, Rio de Janeiro, 216 pp (In Portuguese).

Bergado, D.T.; Long, P.V. \& Murthy, B.R.S. (2002) A case study of geotextile-reinforced embankment on soft ground. Geotextiles and Geomembranes, v. 20:6, p. $343-365$.

Bergado, D.T.; Long, P.V.; Lee, C.H.; Loke, K.H. \& Werner, G. (1994) Performance of reinforced embankment on soft Bangkok clay with high-strength geotextile reinforcement. Geotextiles and Geomembranes, v. 13:6-7, p. 403-420.

Brinkgreve, R.B.J. \& Vermeer, P.A. (2004) Reference Manual - Plaxis Finite Element Code for Soil and Rock 
Analysis Version 8.6, Balkema, Rotterdam, The Netherlands.

British Standard BS-8006 (2005) Code of Practice for Strengthened/Reinforced Soils and Other Fills. British Standards Group, United Kingdom.

Cappadoro, A.P.; Porta, R. \& Turello, D. (2007) Analysis of geogrids reinforced embankments over soft soils, numerical simulation. Graduate Thesis. Universidad Tecnológica Nacional, Santa Fe, Argentina, 275 pp (In Spanish).

Duncan, J.M. \& Buchigani, A.L. (1976) An engineering manual for settlement studies. Geotechnical Engineering Report, Department of Civil Engineering, University of California at Berkeley, p. 94.

Futai, M.M. (2010) Considerations on the influence of the secondary consolidation and the use of reinforcement in embankments on soft soils. Post-Doctoral Thesis. University of São Paulo, São Paulo, 178 pp (In Portuguese).

Hinchberger, S.D. \& Rowe, R.K. (2003) Geosynthetic reinforced embankments on soft clay foundations: predicting reinforcement strains at failure. Geotextiles and Geomembranes, v. 21:3, p. 151-175.

Jewell, R.A. (1982) A limit equilibrium design method for reinforced embankments on soft foundations. Proc. $2^{\text {nd }}$ International Conference on Geotextiles, Las Vegas, v. 4, pp. 671-676.

Magnani, H.O.; Ehrlich, M. \& Almeida, M.S.S. (2010) Embankments over soft clay deposits: contribution of basal reinforcement and surface sand layer to stability. Journal of Geotechnical and Geoenvironmental Engineering, v. 136:1, p. 260-264.

Massad, F. (2009) Marine soils from Santos region, characteristics and geotechnical properties. Ed. Oficina de Textos, São Paulo, p. 247. (In Portuguese).
Michalowski, R.L. (1992) Bearing capacity of nonhomogeneous cohesive soils under embankments. Journal of Geotechnical Engineering Division, v. 118:9, p. 10981118.

Moraes, C.M. (2002) Reinforced embankments over soft soils, numerical and analytical study. MSc. Thesis, Universidade Federal do Rio de Janeiro, Rio de Janeiro, p. 223 (In Portuguese).

Palmeira, E.M.; Pereira, J.H.F. \& da Silva, A.R.L. (1998) Back-analyses of geosynthetic reinforced embankments on soft soils. Geotextiles and Geomembranes, v. 16:5, p. 273-292.

Rowe, R.K. (1984) Reinforced embankments: analysis and design. Journal of the Geotechnical Engineering Division, v. 110:2, p. 231-246.

Rowe, R.K. \& Taechakumthorn, C. (2011) The interaction between reinforcement and vertical drains and effect of performance of embankments on soft ground. Soils and Rocks, v. 34:4, p. 261-275.

Rowe, R.K. \& Soderman, K.L. (1987) Reinforcement of embankments on soils whose strength increases with depth. Proc. Geosynthetics 87, New Orleans, pp. 266277.

Rowe, R.K.; Gnanendran, C.T.; Landva, A.O. \& Valsangkar, A.J. (1995) Construction and performance of a full-scale geotextile reinforced test embankment, Sackville, New Brunswick. Canadian Geotechnical Journal, v. 32:3, p. 512-534.

Schanz, T.; Vermeer, P.A. \& Bomeer, P.G. (1999) The Hardening Soil Model: formulation and verification. In: Beyond 2000 in Computational Geotechnics, 10 years of PLAXIS. Balkema, Rotterdam, The Netherlands. 



\section{Technical Note}

\section{Soils and Rocks \\ v. 36, n. 3}





\title{
Cadmium Transport Parameters in a Clayey Residual Soil with Different Values of Contaminant pH
}

\author{
A. Thomé, E.P. Korf, R.S. Tímbola, N.C. Consoli
}

\begin{abstract}
Pollutants containing metals are an important source of environmental impact. The contaminant's $\mathrm{pH}$ and the soil are factors that influence the migration in the subsurface. The determination of parameters through analytical solutions is fundamental to predict contaminant subsurface migration in porous media. The objective of this study was to analyze the cadmium (Cd) transport parameters present in solutions with different $\mathrm{pH}$ ranges in a clayey residual soil from Southern Brazil. Column tests were carried out with residual soil and contaminant solutions containing the following $\mathrm{pH}$ values: 1.35 and 4.50. The transport parameters $R_{d}, k_{d}$, and $D_{h}$ were determined. It was possible to verify that the magnitude of the parameters was increased with a higher $\mathrm{pH}$, a favorable factor for contaminant attenuation.
\end{abstract}

Keywords: column tests, residual soil, retardation factor, heavy metals, $\mathrm{pH}$ effect.

\section{Introduction}

Soil contamination by metals is a great environmental concern in many parts of the world due to fast industrialization, growing urbanization, the modernization of agricultural practices and inadequate waste disposal methods (Lestan et al., 2008). Brazil and developing countries still need further studies, particularly on the determination of contamination transport parameters in residual soils.

Waste containing metals originates mostly from solid urban and industrial waste; accidental leaks and spills; electroplating activities; mining and foundry; synthetic agricultural fertilizers and pesticides; atmospheric deposition of pollutants originated from volatilized phytosanitary products; vehicle emissions; waste incineration and transport; industrial processes and energy production processes; agricultural waste and sludge from effluent and sewage treatment plants (Bermea et al., 2002; Renella et al., 2004; Soares, 2004; Walker, 2006; Yong et al., 1992).

The main destination of solid waste is the soil. When these solid wastes have metallic constituents and they are disposed on the soil, they may contaminate not only the soil itself, but also, superficial waters (through superficial drainage) and groundwater (through migration to the subsurface). When the metals are present in the environment in concentrations many times higher than the natural ones, they can cause toxicity problems in exposed organisms such as plants, animals and humans. This is because they can penetrate in the food chain, due to their mobility in different environmental compartments (Nordberg et al., 2005; Repetto, 1995).
There are much researches being developed in Brazil and other countries about migration of contaminants in soils. However, studies capable of simulating the movement of contaminants in residual soils in Brazil still are necessary. This is important because they can help in the process of managing and controlling contamination of containment structures design. For these studies, it is necessary to obtain the transport parameters that characterize the physical and chemical nature of the distribution of contaminants in soils (Adebowale et al., 2006; Buszewski \& Kowalkowski, 2006; Giannakopoulou et al., 2007).

The transport of metal contaminants in subsurfaces is influenced by several factors that may determine greater, smaller or no movement in the soil, depending on the nature of the mechanisms involved. All these process are ruled by physical, chemical and biological processes (Yong et al., 1992; Shackelford, 1993; Costa, 2002; Moncada, 2004; Sharma \& Reddy, 2004; Knop et al., 2008).

The $\mathrm{pH}$ is one of the main factors that can influence the transport of metal in soils. The acid range presents the greatest mobility, which can vary and even suffer a reduction when the $\mathrm{pH}$ is close to neutral and basic, as described in the literature for residual soils (Basta et al., 2001; Costa, 2002; Elzahabi \& Yong, 2004; Jesus, 2004; Meurer et al., 2006; Lopes, 2009; Korf, 2011). In this study, this factor is assessed with the aim of investigating its influence on the nature of the physical and physicochemical processes involved in the transport of $\mathrm{Cd}$, reproducing contaminant from a variety of sources. It was chosen $\mathrm{Cd}$ due to its high mobility in soils, which offers critical conditions.

A. Thomé, Ph.D., Professor, Graduate Program in Civil and Environmental Engineering, Universidade de Passo Fundo, BR 285, Caixa Postal 611, $99001-970$ Passo Fundo, RS, Brazil. e-mail: thome@upf.br.

E.P. Korf, Professor, Environmental Engineering, Universidade de Passo Fundo, BR 285, Caixa Postal 611, 99001-970 Passo Fundo, RS, Brazil. e-mail: eduardokorf@ upf.br. R.S. Tímbola, Master Student, Graduate Program in Civil and Environmental Engineering, Universidade de Passo Fundo, BR 285, Caixa Postal 611, 99001-970 Passo Fundo, RS, Brazil. e-mail: rafaeltimbola@hotmail.com.

N.C. Consoli, Ph.D., Professor, Graduate Program in Civil Engineering, Universidade Federal do Rio Grande do Sul, Av. Osvaldo Aranha $99,3^{\circ}$ Andar, 90035190 Porto Alegre, RS, Brazil. e-mail: consoli@ufrgs.br.

Submitted on October 2, 2012; Final Acceptance on September 6, 2013; Discussion open until April 30, 2014. 
The objective of this study was to analyze the $\mathrm{Cd}$ transport parameters present in solutions with different $\mathrm{pH}$ ranges in a clayey residual soil from south Brazil.

\section{Material and Methods}

\subsection{Residual soil}

The soil sample was collected at the geotechnical experimental field of the University of Passo Fundo - UPF. The coordinates of the collection location are: Longitude 363903 m, Latitude 6876922 m (Coordinates UTM - Universal Transverse of Mercator - 22S).

In the pedological classification it is an oxisol (Streck, 2002). These soils are very deep, drained and highly weathered, presenting a sequence of $\mathrm{A}-\mathrm{Bw}$ and $\mathrm{C}$ horizons, where $\mathrm{Bw}$ is latossolic. These soils have little increase of clay with depth and gradual transition between the horizons. As they are very weathered, kaolinite and iron oxides predominate, resulting in low CEC (cation exchange capacity), high acidity and low nutrient stock (Streck, 2002). The geotechnical and chemical characterization of the soil from horizon B is presented in Table 1. The characterization shows low content of organic material, high content of clay, low $\mathrm{pH}$, which when compared with the zero point of charge (ZPC) shows a negative predominant charge.

\subsection{Contaminant solution}

The contaminant solution contains $\mathrm{Cd}$ dissolved in distilled water. Its concentration was extrapolated by 100 times the Brazilian Code Intervention Value for Groundwater - CONAMA (2009) what is equivalent at 167 times World Health Organization Recommendation Values - WHO (2004), simulating a large contamination source. The concentration inserted was $0.5 \mathrm{mg} \cdot \mathrm{L}^{-1}$, which was achieved through diluting a standard solution of $\mathrm{Cd}$ at a concentration of $1000 \mathrm{mg} . \mathrm{L}^{-1}$. The contaminant solution was prepared in the $\mathrm{pH}$ ranges 1.35 and 4.50 .

\subsection{Molding of the test samples}

An undisturbed soil sample was extracted from B horizon in the shape of $0.30 \mathrm{~m}$ edge cubic block, from which
Table 1 - Geotechnical and chemical characterization of the clayey residual soil.

\begin{tabular}{|c|c|}
\hline Parameter & Value \\
\hline Clay $(\%)$ & 68 \\
\hline Silt $(\%)$ & 5 \\
\hline Sand $(\%)$ & 27 \\
\hline Liquid Limit (\%) & 53 \\
\hline Plastic Limit (\%) & 42 \\
\hline Plasticity Index & 11 \\
\hline$G_{s}($ Specific gravity) & 2.67 \\
\hline Natural Water Content (\%) & 34 \\
\hline Natural Unit Weight $\left(\mathrm{kN} / \mathrm{m}^{3}\right)$ & 16.3 \\
\hline Void ratio & 1.19 \\
\hline Saturation degree $(\%)$ & 75.7 \\
\hline Porosity (\%) & 54 \\
\hline $\mathrm{pH}$ & 4.3 \\
\hline Zero Point of Charge (ZPC) & 3.1 \\
\hline Organic Matter Content (\%) & $<0.8$ \\
\hline $\operatorname{CEC}\left(\mathrm{cmol}_{\mathrm{c}} / \mathrm{dm}^{3}\right)$ & 8.6 \\
\hline SSA (Specific Surface Area) $)_{\text {intermaltexternal }}\left(\mathrm{m}^{2} / \mathrm{g}\right)$ & 33.86 \\
\hline
\end{tabular}

cylindrical probes were molded with $0.05 \mathrm{~m}$ diameter and variable heights. Table 2 presents the physical indices and dimensions of all the tested samples.

\subsection{Column test}

The column test was the methodology adopted to assess the attenuation capacity of the soil. The column test reproduces the transport of a pollutant through the soil (ASTM, 1995). The test is carried out in two stages, the first one is the saturation of the soil with distilled water, and the second one is the percolation of the contaminant solution, both performed in constant head and lasting about four hours each. The equipment used is a flexible wall permeameter with upstream flow that allows the samples to be tested simultaneously, hence, triplicates for each $\mathrm{pH}$. The confining pressure used in all tests was $40 \mathrm{kPa}$.

Table 2 - Physical indexes and dimensions of the samples tested.

\begin{tabular}{ccccccccc}
\hline $\mathrm{pH}$ & $\begin{array}{c}\text { Test } \\
\text { sample }\end{array}$ & $\begin{array}{c}\text { Water content } \\
(\%)\end{array}$ & $\begin{array}{c}\text { Height } \\
(\mathrm{cm})\end{array}$ & $\begin{array}{c}\text { Diameter } \\
(\mathrm{cm})\end{array}$ & $\begin{array}{c}\text { Specific weight } \\
\left(\mathrm{g} / \mathrm{cm}^{3}\right)\end{array}$ & $\begin{array}{c}\text { Void } \\
\text { ratio }\end{array}$ & $\begin{array}{c}\text { Porosity } \\
(\%)\end{array}$ & $\begin{array}{c}\text { Void volume } \\
\left(\mathrm{cm}^{3}\right)\end{array}$ \\
\hline \multirow{2}{*}{1.35} & 1 & 35.27 & 9.22 & 4.93 & 1.50 & 1.41 & 58 & 102.74 \\
& 2 & 32.50 & 6.40 & 5.17 & 1.43 & 1.46 & 59 & 79.85 \\
& 3 & 34.62 & 8.66 & 4.57 & 1.51 & 1.38 & 58 & 82.38 \\
\hline \multirow{2}{*}{4.50} & 4 & 35.27 & 8.04 & 4.74 & 1.57 & 1.29 & 56 & 80.10 \\
& 5 & 32.50 & 10.35 & 4.82 & 1.53 & 1.39 & 57 & 107.28 \\
& 6 & 32.50 & 12.09 & 4.84 & 1.56 & 1.27 & 56 & 124.06 \\
\hline
\end{tabular}


The effluent was collected each time that accumulated volume was sufficient for send the contaminant to analysis. The metal concentration was determined using an atomic absorption spectrophotometer.

After determining the metal concentration in the contaminated solution that was percolated through the samples, it was possible to obtain the contaminant's breakthrough curve. The contaminant breakthrough curve shows, on axis $x$, the number of percolated pores (percolated volume / void ratio - Vperc/Vv) or percolation time $(t)$, and on axis $y$ the relative concentration of the contaminant (concentration of percolated waste/initial concentration $-C / C_{0}$ ). Table 3 presents the hydraulic characteristics of the 6 samples tested.

\subsection{Determination of the transport parameters in the column test}

Retardation Factor $\left(R_{d}\right)$ was calculated by the method presented by Shackelford (2005), which defines the area above the breakthrough curve as the value for $R_{d}$. In this case, for the curves that did not reach $C / C_{0}=1$, the experimental data were extrapolated by linear trend until a unitary relation was reached.

The coefficient of distribution $\left(k_{d}\right)$ considers the linear relation between the mass absorbed by unit of solid mass and the concentration of the substance that remains in solution, after reaching equilibrium, in a saturated soil. Equation 1 presents the equation for $k_{d}$ (Ogata \& Banks, 1961). In the equation $r_{s}$ is the specific dry mass of the soil and $\mathrm{n}$ is the porosity.

$$
k_{d}=\frac{R_{d}-1}{\rho_{s}} \times n
$$

Ogata \& Banks (1961) developed an analytical solution for the model of contaminant transport in homogenous and saturated soils where there is interaction between the porous material and the contaminant. Equation 2 presents the analytical solution for a reactive solute followed by their initial and boundary conditions, where there is the occurrence of bio-physicochemical contaminant attenuation processes. In the equation $D_{h}$ is the hydrodynamic dispersion; $C / C_{0}$ is the relative concentration or concentration of percolated waste/initial concentration; $L$ is the unidimensional flow distance; $t$ is the percolation time, $v_{s}$ is the percolation velocity and erfc is the complementary error function for analytical solution.

$$
\begin{aligned}
& \frac{C}{C_{0}}=\frac{1}{2}\left[\operatorname{erfc}\left(\frac{R_{d} L-v_{s} t}{2 \sqrt{D_{h} R_{d} t}}\right)+e^{\frac{v_{s} L}{D_{h}}} \operatorname{erfc}\left(\frac{R_{d} L+v_{s} t}{2 \sqrt{D_{h} R_{d} t}}\right)\right] \\
& c(x, t)\left\{\begin{array}{l}
C(x, 0)=0 \Rightarrow x \geq 0 \\
C(0, t)=C_{0} \Rightarrow t \geq 0 \\
C(\infty, t)=0 \Rightarrow t \geq 0
\end{array}\right.
\end{aligned}
$$

The analytical solution was used to do the adjustment of a theoretical curve obtained through the Ogata and Banks solution (Eq. 2) to the transport curve (breakthrough) originated from the column test. For the construction of the theoretical curve, the " $\mathrm{C} / \mathrm{C}_{0}$ " values were found by fixing the parameters calculated and varying $D_{h}$ and time $(t)$, until the optimization of the adjustment to the experimental curve. The best adjustment of the theoretical to the experimental curve determined, by back analysis, the value of the $D_{h}$ parameter.

\section{Results and Discussion}

Figure 1 presents the experimental results of the column test, along with the curve, analytically adjusted by Ogata \& Banks (1961) methodology, to pH 1.35 and 4.50. The analysis of the experimental curves' adjustments to the theoretical model, presented in Fig. 1, shows that the relation $C / C_{0}=1$ was reached faster for $\mathrm{pH} 1.35$ than for $\mathrm{pH}$ 4.50. For $\mathrm{pH} 1.35$, on average, the maximum retention of ions of the contaminant in the soil occurred between $100 \mathrm{~min}$ and $200 \mathrm{~min}$ (5.98 Vperc/Vv and $11.35 \mathrm{Vperc} / \mathrm{Vv})$, respectively, after the start of the test.

The relation $C / C_{0}=1$ in the experimental curves occurred only with $\mathrm{pH} 1.35$. For $\mathrm{pH} 4.50$, only was possible reached $C / C_{0}=1$ through the extrapolation of the curve obtained by the analytical solution, showing an increase in the delay of the contamination plume in consonance with the $\mathrm{pH}$ increase.

Table 4 presents the transport parameters obtained for all the samples tested with $\mathrm{pH} 1.35$ and 4.50. The table shows the average, the standard deviation and the coeffi-

Table 3 - Hydraulic characteristics of the sample tested.

\begin{tabular}{lccccc}
\hline $\mathrm{pH}$ & Test & Hydraulic head $(\mathrm{m})$ & Hydraulic gradient (i) & Hydraulic conductivity $(\mathrm{m} / \mathrm{s})$ & Percolation velocity $(\mathrm{m} / \mathrm{s})$ \\
\hline \multirow{2}{*}{1.35} & 1 & 1.2 & 12.98 & $5.9 \times 10^{-6}$ & $7.67 \times 10^{-5}$ \\
& 2 & 1.2 & 18.69 & $3.7 \times 10^{-6}$ & $6.83 \times 10^{-5}$ \\
& 3 & 2.0 & 23.15 & $1.4 \times 10^{-6}$ & $3.17 \times 10^{-5}$ \\
\hline \multirow{2}{*}{4.50} & 4 & 2.8 & 14.23 & $7.2 \times 10^{-6}$ & $1.03 \times 10^{-4}$ \\
& 5 & 3.0 & 6.41 & $1.1 \times 10^{-5}$ & $6.83 \times 10^{-5}$ \\
& 6 & 2.7 & 9.47 & $1.2 \times 10^{-5}$ & $1.13 \times 10^{-4}$ \\
\hline
\end{tabular}




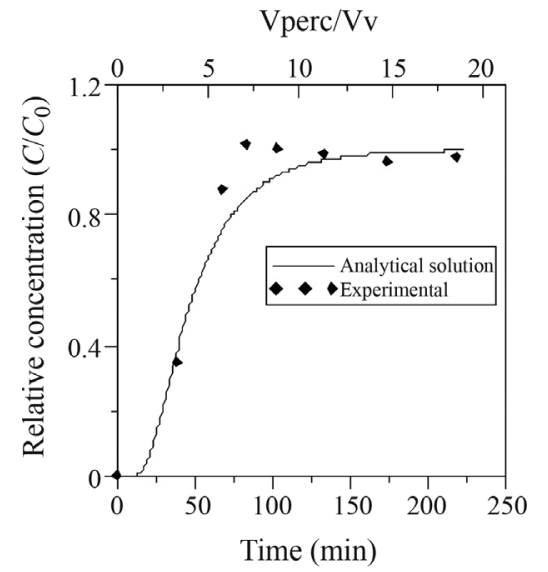

$\mathrm{CP} 1$

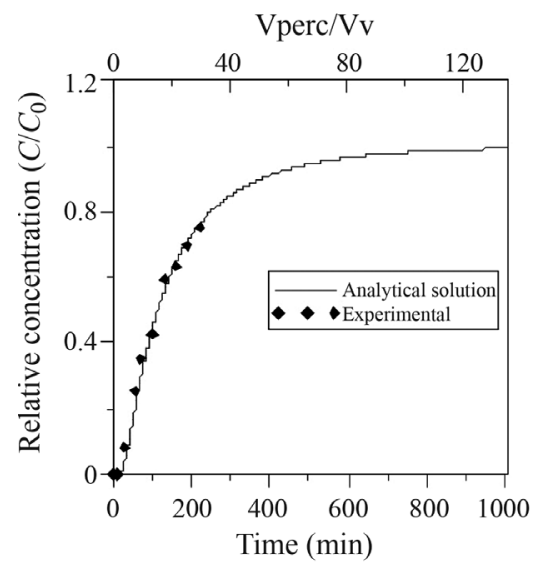

CP4
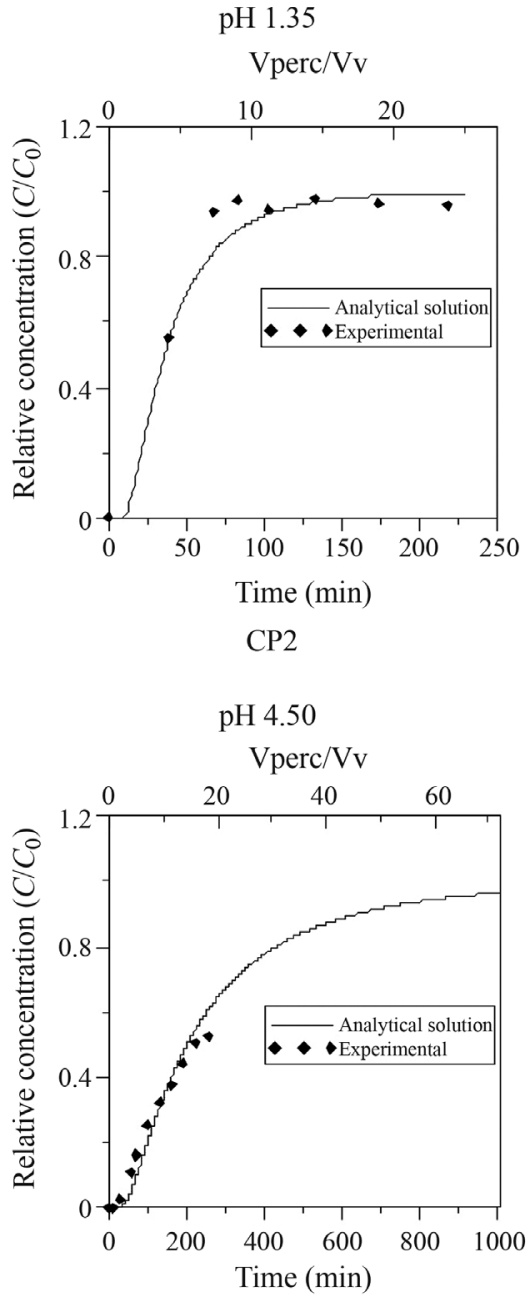

CP5

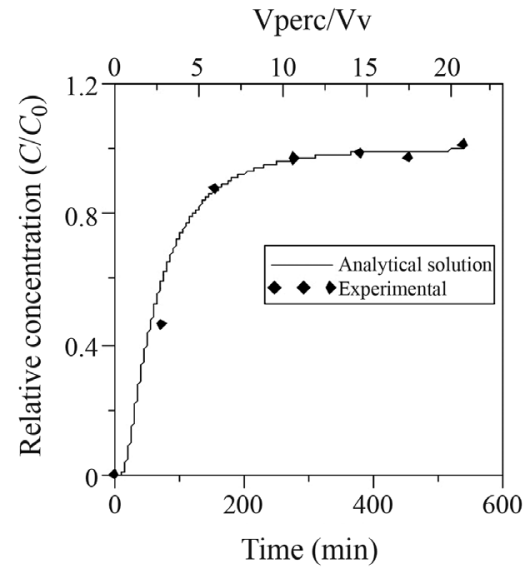

$\mathrm{CP} 3$

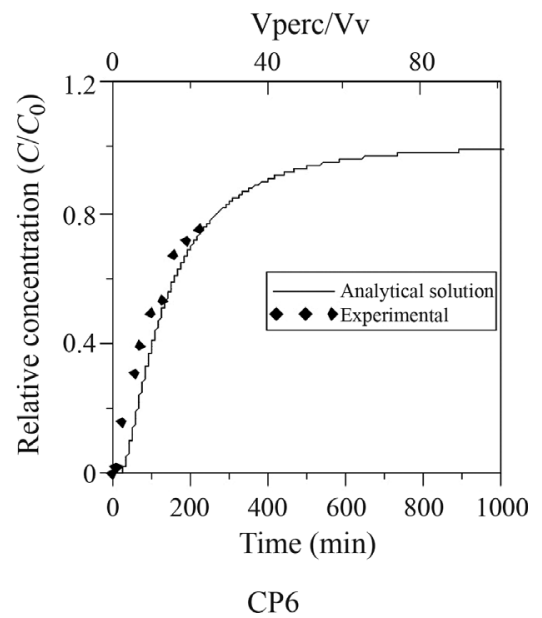

Figure 1 - Experimental results and adjustment by Ogata \& Banks (1961) methodology of the tests carried out with pH 1.35 and 4.50.

cient of variation for the results related to the samples tested with each $\mathrm{pH}$. For $R_{d}$ and $k_{d}$ the coefficient of variation was not higher than $20 \%$. However, for $D_{h}$ the value approached $35 \%$, on average. The analysis of the variance of the different $\mathrm{pHs}$ for $R_{d}, k_{d}$ and $D_{h}$ showed significance for all the responses $(\mathrm{p}<0.02)$.

The average values of the physicochemical parameters for $k_{d}$ were $2.55 \times 10^{-3} \mathrm{~m}^{3} \cdot \mathrm{kg}^{-1}$ with $\mathrm{pH} 1.35$ and 10.85 $\mathrm{x} 10^{-3} \mathrm{~m}^{3} \cdot \mathrm{kg}^{-1}$ with $\mathrm{pH} 4.50$, and for the $R_{d}$ parameter it was 5.83 with $\mathrm{pH} 1.35$ and 23.35 with $\mathrm{pH} 4.50$. When $\mathrm{pH}$ increase from 1.35 to 4.50 , it was observed a significant increase $(\mathrm{p}<0.001)$ in the delay parameters, by approximately 4 times. This fact was expected, once several authors state that an increase in $\mathrm{pH}$ can favor the metals precipitation and increase ionic exchange or changeable adsorption, which is one of the main contributing mechanisms to adsorption in soils with a predominance of variable surface charges (Elzahabi \& Yong, 2001; Basta et al., 2001; Costa, 2002; Jesus, 2004; Meurer et al., 2006; Lopes, 2009; Korf, 2011).
Yong et al. (1992) stated that the observed increase in metal retention capacity with the $\mathrm{pH}$ increasing occurs when the soil solution exceeds the zero point of charge. In this case, there is the formation of the $\mathrm{pH}$-dependent negative charge and may also occur precipitation reaction, as reported in the literature (e.g. Schwertmann \& Taylor, 1989; Lagrega, 1994; Elzahabi \& Yong, 2001; Adebowale et al., 2006).

The parameter $D_{h}$ presented a significant difference between the $\mathrm{pH}$ values studied, in the order of $1.22 \times 10^{-6} \mathrm{~m}^{2} / \mathrm{s}$ with $\mathrm{pH} 1.35$ and $5.00 \times 10^{-6} \mathrm{~m}^{2} / \mathrm{s}$ with $\mathrm{pH}$ 4.50. It was observed that the variation was approximately 4 times between the $\mathrm{pH}$ values studied, with the same relation maintained for the $k_{d}$ and $R_{d}$ values. This increase may have occurred due to the obtention of the parameter by back analysis of Eq. 2, which is influenced by parameter $R_{d}$.

In comparison with literature values, $D_{h}$ are higher than the ones obtained in similar studies, such as Azevedo et al. (2005) and Lange (2002), who studied respectively, the percolation of metals in clay soils of landfill and an 
Table 4 - Contaminant transport parameters obtained for $\mathrm{Cd}$.

\begin{tabular}{ccccc}
\hline $\mathrm{pH}$ & Test sample & $R_{d}$ & $k_{d}\left(\mathrm{~m}^{3} / \mathrm{kg}\right)$ & $D_{h}\left(\mathrm{~m}^{2} / \mathrm{s}\right)$ \\
\hline 1.35 & 1 & 5.00 & $2.09 \times 10^{-3}$ & $1.50 \times 10^{-6}$ \\
& 2 & 5.50 & $2.45 \times 10^{-3}$ & $1.50 \times 10^{-6}$ \\
& 3 & 7.00 & $3.10 \times 10^{-3}$ & $6.67 \times 10^{-7}$ \\
& Average & $5.8 \pm 1.0$ & $2.55 \times 10^{-3}$ & $1.22 \times 10^{-6}$ \\
& Standard deviation & 1.04 & $0.51 \times 10^{-3}$ & $4.83 \times 10^{-7}$ \\
& Coefficient of & 17.84 & 20.10 & 39.36 \\
variation (\%) & & & \\
\hline \multirow{4}{*}{$4.50 \quad$} & 26.00 & $12.07 \times 10^{-3}$ & $4.67 \times 10^{-6}$ \\
& 23.04 & $10.92 \times 10^{-3}$ & $3.67 \times 10^{-6}$ \\
& 5 & 21.00 & $9.57 \times 10^{-3}$ & $6.67 \times 10^{-6}$ \\
& Average & $23.3 \pm 2.5$ & $10.85 \times 10^{-3}$ & $5.00 \times 10^{-6}$ \\
& Standard deviation & 2.51 & $1.25 \times 10^{-3}$ & $1.53 \times 10^{-6}$ \\
Coefficient of & 10.77 & 11.53 & 30.55 \\
variation (\%) & & & \\
p & $<0.001$ & $<0.001$ & 0.015 \\
\hline
\end{tabular}

*p value of the variance analysis.

Table 5 - Range of the parameters proposed for $\mathrm{Cd}$ in residual soil (oxisol).

\begin{tabular}{lccc}
\hline \multirow{2}{*}{$\mathrm{HH}$} & \multicolumn{3}{c}{ Variation range } \\
\cline { 2 - 4 } & $R_{d}$ & $k_{d}\left(\mathrm{~cm}^{3} / \mathrm{g}\right)$ & $D_{h}\left(\mathrm{~cm}^{2} / \mathrm{min}\right)$ \\
\hline 1.35 & $5-7$ & $2.09-3.10$ & $0.4-0.9$ \\
4.50 & $21-26$ & $9.57-12.07$ & $2.2-4.0$ \\
\hline
\end{tabular}

oxisol and obtained values in the range of $10^{-8} \mathrm{~m}^{2} / \mathrm{s}$ and $10^{-9} \mathrm{~m}^{2} / \mathrm{s}$. This behavior can be explained by the difference in structures and mineral formation and direct influence of the low $k_{d}$ and $R_{d}$ values, which also reduced the $D_{h}$ values, which have been obtained through these parameters.

The behavior described makes possible to suggest the range of transport parameters for the $\mathrm{Cd}$ contaminant in the clayey residual soil (oxisol). Table 5 shows the variation range suggested to be used in numerical simulations in engineering designs.

\section{Conclusions}

The results and analyses presented led to the following conclusions:

- Increase in the solution's $\mathrm{pH}$ led to increase in the values of parameters $k_{d}$ and $R_{d}$.

- The $\mathrm{pH}$ increase led to an increase in the $D_{h}$ because their obtention is related to the $R_{d}$, which was influenced by the $\mathrm{pH}$.

- The values of the contaminant transport parameters obtained in this study can be used as indicators in the design of engineering projects in the residual clayey soil (oxi- sol), when percolated by cadmium dissolved in an acid medium.

\section{Acknowledgments}

The authors wish to express their gratitude to the Brazilian Research Councils (CNPq/MCT and CAPES/MEC) and Rio Grande do Sul Research Council (FAPERGS) for their financial support.

\section{References}

Adebowale, K.O.; Unuabonah, I.E. \& Olu-Owolabi B.I. (2006) The effect of some operating variables on the adsorption of lead and cadmium ion son kaolinite clay. Journal of Hazardous Materials, v. 134:1-3, p. 130-139.

American Society for Testing and Materials - ASTM (1995) Standard Test Method for Leaching Solid Material in a Column Apparatus - D4874, ASTM International, West Conshohocken, Pennsylvania, USA, 8 pp.

Azevedo, I.C.D.; Nascentes, R.C.; Matos; T.A. \& Azevedo, F.R. (2005) Transport parameters determination of heavy metals in an Oxisol compacted, Revista de Engenharia Agrícola e Ambiental, v. 9:4, p. 623-630.

Basta, N.T.; Gradwohl, R.; Snethen, K.L. \& Schroder, J.L. (2001) Chemical immobilization of lead, zinc, and cadmium in smelter-contaminated soils using biosolids and rock phosphate. Journal of Environmental Quality, v. 30:4, p.1222-1230.

Bermea, O.M.; Alvarez, E.H. \& Segovia, G.N. (2002) Heavy metal concentrations in surface soils from Mexico City. Bulletin of Environmental Contamination and Toxicology, v. 68:3, p. 383-388.

Buszewski, B. \& Kowalkowski, T. (2006) A new model of heavy metal transport in the soil using nonlinear artificial neural networks. Environmental Engineering Science, v. 23:4, p. 589-595.

CONAMA (2009) Resolution \# 420 - Provides for criteria and guiding values of soil quality for the presence of chemical substances and establishes guidelines for environmental management of areas contaminated by these substances due to anthropogenic activities. D.O.U, n. 249, Brazil, pp. 81-84.

Costa, P.O.S. (2002) Laboratory Evaluation, of the Contaminants Transport in Soil of Landfill Sauipe/Ba. Master's Thesis, Departamento of Civil Engineering, Pontifícia Universidade Católica do Rio de Janeiro, Rio de Janeiro, $171 \mathrm{pp}$.

Elzahabi, M. \& Yong, R.N. (2001) pH Influence on sorption characteristics of heavy metal in the vadose zone. Engineering Geology, v. 60:1-4, p. 61-68.

Giannakopoulou, F.; Haidouti, C.; Chronopoulou, A. \& Gasparatos, D. (2007) Sorption behavior of cesium on various soils under different $\mathrm{pH}$ levels. Journal of Hazardous Materials, v. 149:3, p. 553-556.

Jesus, C.S. (2004) Diffusion of Zinc in Compact Layer of Residual Soil of Gneiss. MSc Dissertation, Geotech- 
nical Engineering, Department of Civil Engineering. Federal University of Viçosa, Viçosa, Minas Gerais, $90 \mathrm{pp}$.

Knop, A.; VanGulck, J.; Heineck, K.S. \& Consoli, N.C. (2008) Compacted artificially cemented soil-acid leachate contaminant interactions: Breakthrough curves and transport parameters. Journal of Hazardous Materials, v. 155:1-2, p. 269-276.

Korf, E.P. (2011) Reactive and Hydraulic Behavior of a Cemented Soil Mixture for Use in Containment Barriers Contend Acids Waste Lead and Cadmium. MSc. Dissertation, Geotechnical Engineering, Federal University of Rio Grande do Sul, Porto Alegre, Rio Grande do Sul, $143 \mathrm{pp}$.

Krahn, J. (2004) Transport Modeling with CTRAN/W: An Engineering Methodology. 1st edition. GEO-SLOPE International, Calgary, $174 \mathrm{pp}$.

Lange, L.C. (2002) Study of contaminant transport in porous media applied to landfill disposal of municipal solid waste. In: Junior, A.B.C., Lange, L.C., Gomes, L.P \& Pessin, N. Alternatives to solid waste disposal for small urban communities: a collection of technical papers. PROSAB, Florianópolis, p. 85-92.

Lagrega, M.D.; Buckingham, P.L. \& Evans, J.C. (1994) Hazardous Waste Management. McGraw-Hill, Inc. Singapore, $1146 \mathrm{pp}$.

Lestan, D.; Chun-Ling, L. \& Xiang-Dong, L. (2008) The use of chelating agents in the remediation of metalcontaminated soils: A review. Environmental Pollution, v. 153:1, p. 3-13.

Lopes, C.M. (2009) Individual and Competitive Adsorption of Cadmium, Copper, Nickel and Zinc in Soil as a Function of pH. MSc. Dissertation, Soil Science and Plant Nutrition, University of de São Paulo, Piracicaba, $100 \mathrm{pp}$.

Meurer, E.J.; Rheinheimer, D. \& Bissan, C.A. (2006) Fundamentals of Soil Chemistry. 3rd edition. Evangraf, Porto Alegre, $285 \mathrm{pp}$.

Moncada, M.P.H. (2004) Laboratory Study of Characteristics of Collapse and Solute Transport Associated with the Infiltration of Caustic Liquor in a Lateritic Soil. Dissertation, Graduate Program in Civil Engineering, Department of Civil Engineering, Catholic University of Rio de Janeiro, Rio de Janeiro, 219 pp.

Nordberg, G.F.; Fowler, B.A.; Nordberg M. \& Friberg, L. (2005) Handbook on the Toxicology of Metals. 3rd edition. European Environment Agency, Copenhage, 224 pp.

Ogata A. \& Banks R.B. (1961) A Solution of the Differential Equation of Longitudinal Dispersion in Porous Media. US Geological Survey, Professional Paper No. 411-A.

Poleto, C. \& Merten, G.H. (2006) Quality of Sediments. Porto Alegre: ABRH, 397 pp.

Renella, G.; Landi, L. \& Nannipieri, P. (2004) Degradation of low molecular weight organic acids complexed with heavy metals in soil. Geoderma, v. 122:2-4, p. 11-315.

Repetto, M. (1995) Advanced Toxicology. Díaz de Santos, Madrid, $621 \mathrm{pp}$.

Shackelford, C.D. (1993) Contaminant transport. In: Daniel, D.E. (org) Geotechnical Pratictice for Waste Disposal. Chapman \& Hall, London, pp. 33-65

Shackelford, C.D. (1995) Cumulative mass approach for column test. Journal of Geotechnical Enginnering, v. $121: 10$, p. 696-703.

Sharma, H.D. \& Reddy, K.R. (2004) Geoenvironmental engineering: site remediation, waste containment, and emerging waste management technologies. John Wiley \& Sons, New Jersey, 968 pp.

Schwertmann, U.; \& Taylor, R.M. (1989) Iron oxides. In: Dixon, J.B. \& Weed S.B. (eds) Minerals in Soil Environments. ASA and SSSA, Madison, pp. 379-438.

Soares, M.R. (2004) Distribution coefficient $\left(K_{d}\right)$ of heavy metals in soils of São Paulo. Thesis Doctorate in Agronomy, Soil and Plant Nutrition, University of Sao Paulo, Piracicaba, São Paulo, 202 pp.

Streck, E.V. (2002) Soils of Rio Grande do Sul. EMATER, Porto Alegre, $107 \mathrm{pp}$.

WHO (2004) Guidelines of Drinking Water Quality, 3 rd edition, vol. 1. Recommendation. World Health Organization, Geneva, Switzerland, 515 pp.

Walker, C.H. (2006) Principles of ecotoxicology. 3rd edition. Taylor \& Francis, Boca Raton. 344 pp.

Yong, R.N.; Mohamed, A.M.O. \& Warkentin, B.P. (1992) Principles of Contaminant Transport in Soils. Elsevier, Amsterdam, 327 pp.

Yong, R.N. (2001) Geoenvironmental Engineering, Contaminated Soils, Pollutant Fate, and Mitigation. CRC Press, Boca Raton, 307 pp.

\section{List of Symbols}

$C / C_{0}$ - Relative concentration or concentration of percolated waste/initial concentration

$D_{h}$ - Hydrodynamic dispersion

erfc - Complementary error function

$i$ - Hydraulic gradient

$k_{d}$ - Coefficient of distribution

$L$ - Unidimensional flow distance

$n$ - Porosity

$\mathrm{p}$ - $\mathrm{p}$ value from variance analysis

$R_{d}$ - Retardation factor

CEC - Cation Exchange Capacity

SSA - Specific Surface Area

UTM - Universal Transverse of Mercator

$t$ - Percolation time

Vperc/Vv - Percolated volume / void volume

$v_{s}$ - Percolation velocity

$\mathrm{r}_{s}$ - Specific dry mass of the soil

$G_{s}$ Specific gravity of the soil

ZPC - Zero Point of Charge 
SOILS and ROCKS

An International Journal of Geotechnical and Geoenvironmental Engineering

\section{Publication of \\ ABMS - Brazilian Association for Soil Mechanics and Geotechnical Engineering SPG - Portuguese Geotechnical Society Volume 36, N. 3, September-December 2013 \\ Author index}

Alcantara, M.A.M.

Assis, A.

Auriol, J.C.

Awruch, A.M.

Braun, A.L.

Cavalcante, A.L.B.

Colla, L.M.

Consoli, N.C.

Costa, L.M.

Cunha, R.P.

Dantas-Ferreira, M.

Danziger, F.A.B.

Ersizad, A.

Espósito, T.

Fahel, A.

Fernandes, L.L.

Ferreira, S.R.M.

Galetto, D.

Gomes, R.C.

Guimarães, L.J.N.

Guimarães, M.G.A.

Guimarães, V.

Hassanlou, M.R.

Hassanlourad, M.

Hemsi, P.S.

Jafari, H.R.

Jannuzzi, G.M.F.

Korf, E.P.

Landi, A.

Langone, M.J.

Lemos, J.V.

Lima, D.C.
209 Lima, R.E.

231

241

159,171

159, 171

129

275

311

183

21

67

265

283

97

1

209

183

231

37

183

251

221

221

299

221

265

311

1

55

137

209

Lollo, J.A.

Mello, L.G.

Ndiaye, M.

Paiva, P.

Pando, M.

Peila, D.

Pejon, O.J.

Pirete, W.
Marefat, V.

Martins, I.S.M.

Meneghetti, L.R.R.

Moussai, B.

Ortigao, J.A.R.

Ozelim, L.C. de S.M.

Palmier, L.R.

Rathie, P.N. 129

Reiffsteck, P. 241

Rodrigues, J.K.G. 241

Ruiz, E.F. 299

Sandroni, S.S. 195

Schnaid, F. 55, 195, 277

Silva, J.C.B.J. 231

Soltani-Jigheh, H. 283

Souto, R. 1

Swamee, P.K. 129

Thomé, A. 275, 311

Tímbola, R.S. 311

Urashima, D.C. 251

Vidal, D.M. 299

Zuquette, L.V. 
GEOTECHNICAL SERVICES (onshore and offshore)

\section{IN-SITU TESTS}

Seismic CPT

Cone Penetration Testing Undrained-CPTu (cordless system)

Vane Shear Testing (electrical apparatus)

Pressuremeter Testing (Menard)

Flat Dilatometer Test-DMT (Machetti)

Standard Penetration Test-SPT-T

\section{INSTRUMENTATION}

Instrumentation, installation and direct import

Routine Monitoring

Operation and Maintenance

Engineering analyses

Consultancy, design \& geotechnical engineering services

\section{SAMPLING}

Soil sampling and monitoring

Groundwater sampling and monitoring

Field and laboratory testing

\section{ENVIRONMENTAL}

Environmental Services

Soil and groundwater sampling and monitoring

Field and laboratory testing

\section{6}

\section{São Paulo: +55 1181336030}

Minas Gerais: +55 $3185632520 / 86196469$

www.deltageo.com.br deltageo@deltageo.com.br

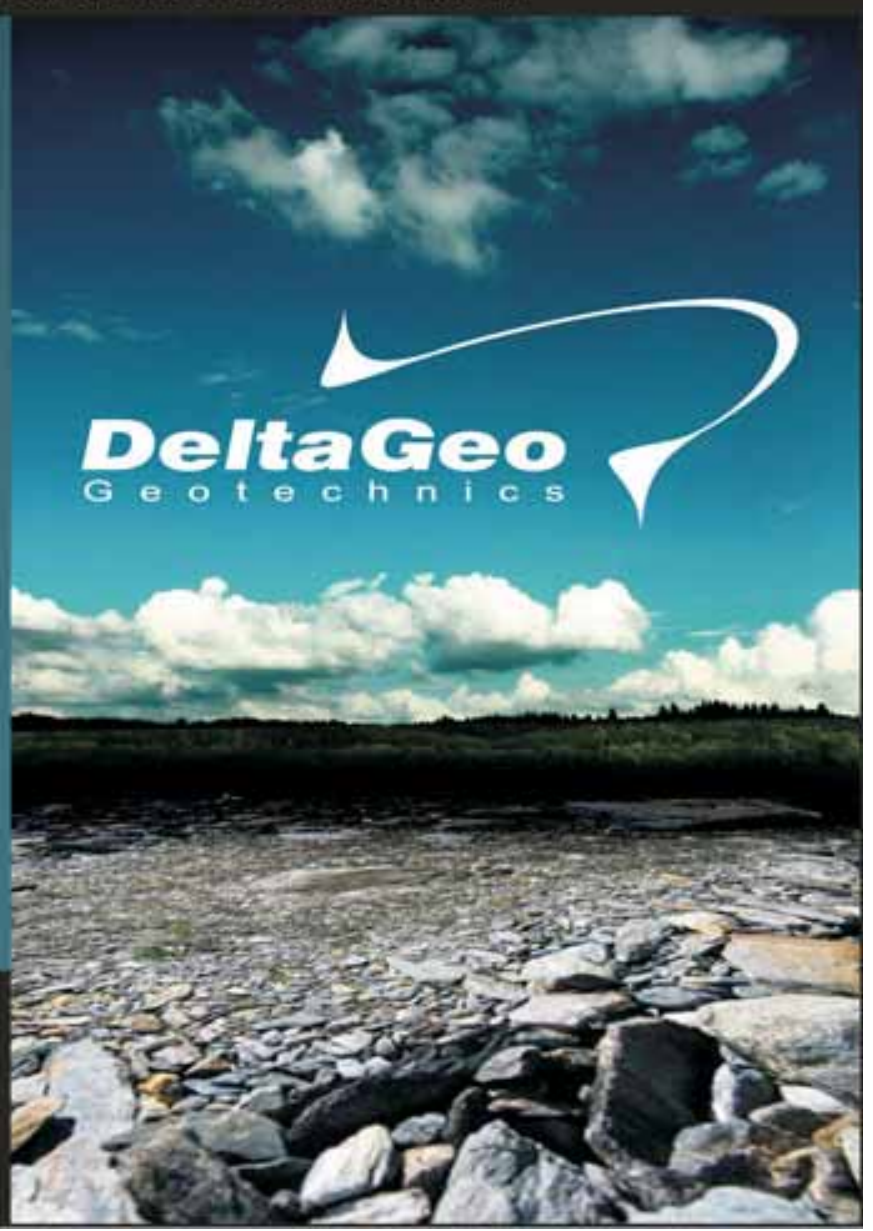


1) We're known for our strength $\ll$

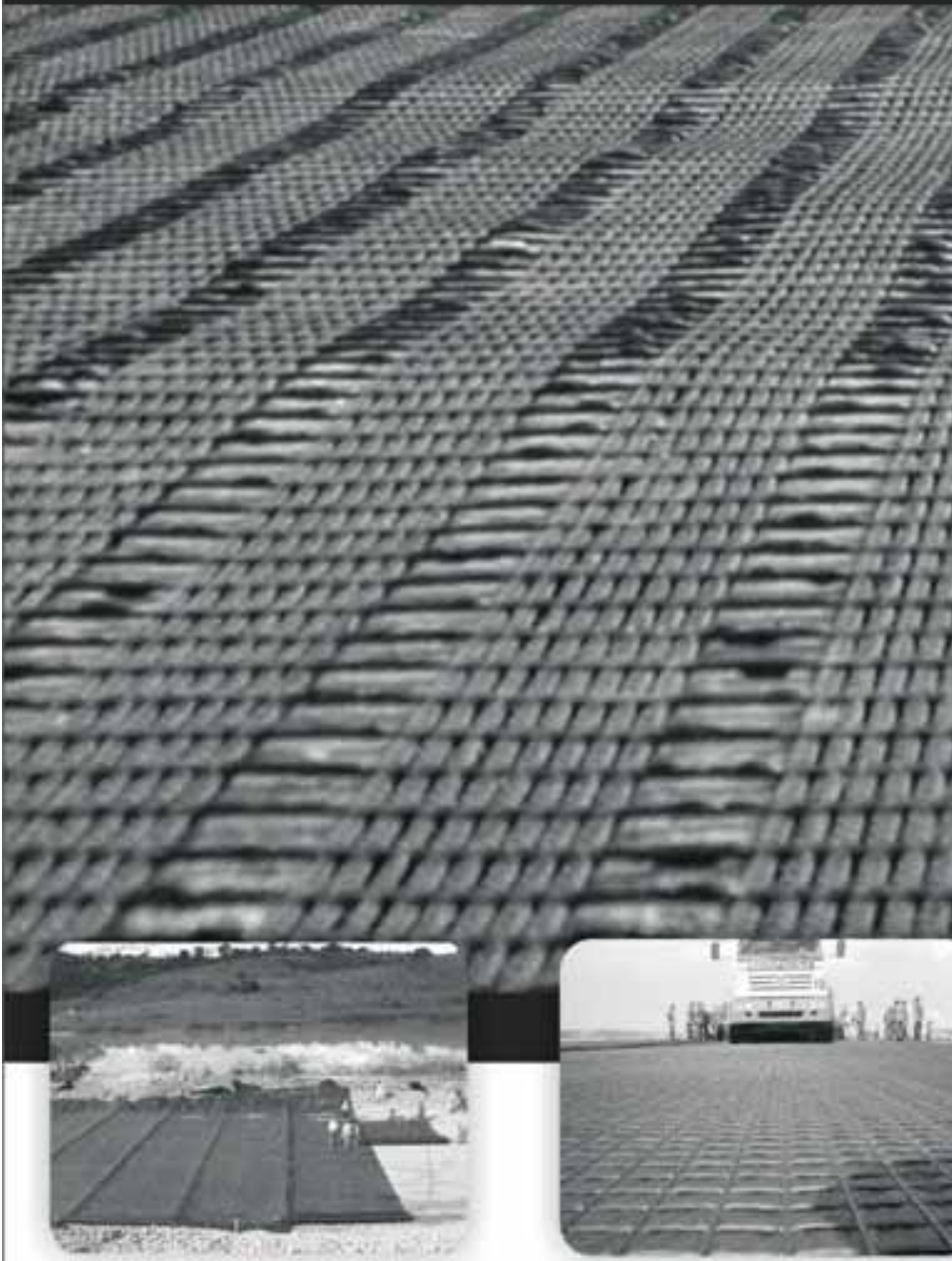

\section{Fortrac}

High tensile stiffness geogrid

for soil reinforcement

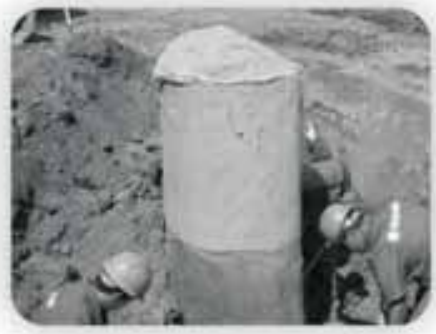

Ringtrac

Ring reinforcement for granular columns on soil improvement
HaTelit C

Flexible grid for asphalt reinforcement

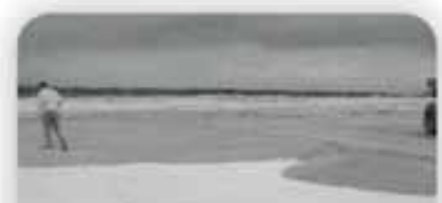

\section{Stabilenka}

High strength woven geosynthetic for soil reinforcement

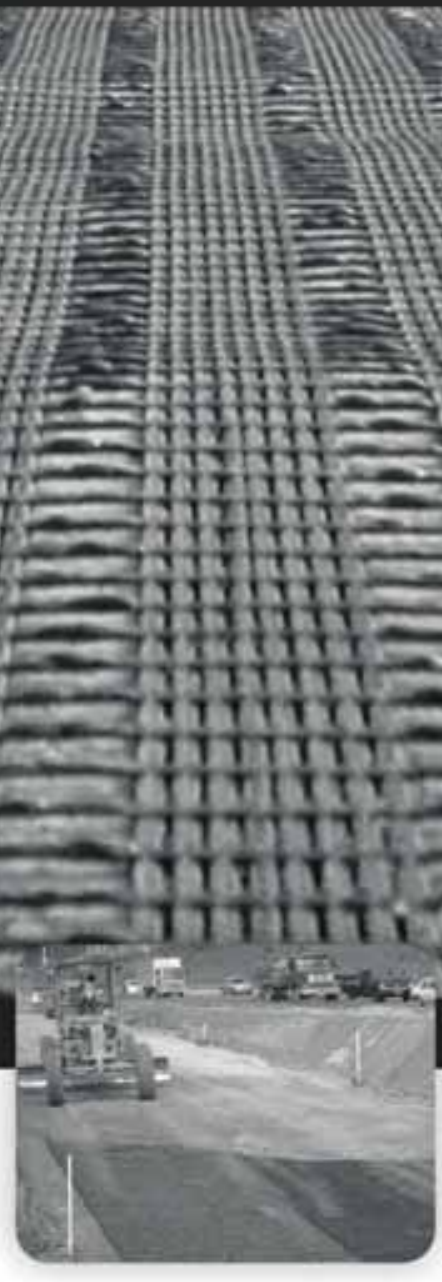

Fornit

Flexible geogrid for bose reinforcement

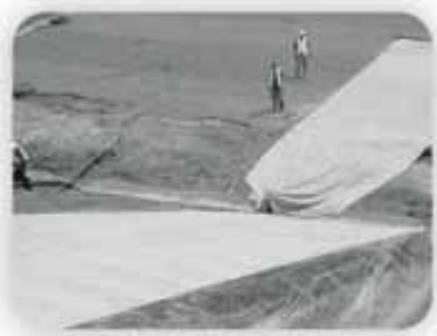

NaBento

Geosynthetic clay liner for sealing

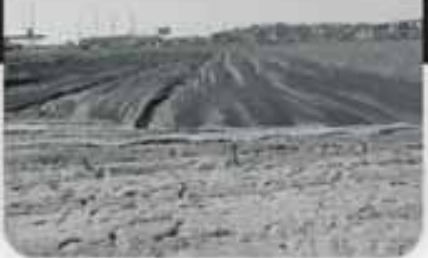

\section{HaTe}

Fabric for separation, stabilization and filtration

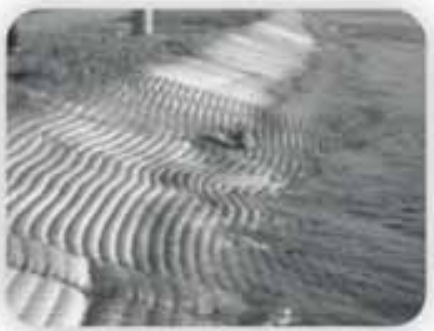

\section{Incomat}

Construction system for slope and bed protection

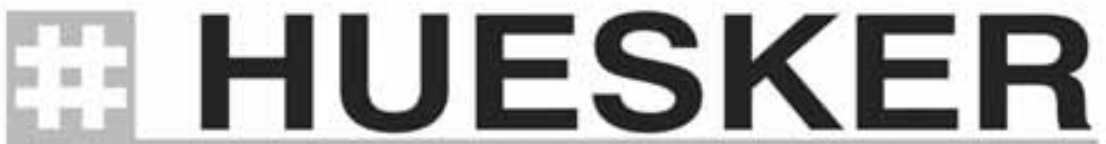

\section{Engineering with Geosynthetics}




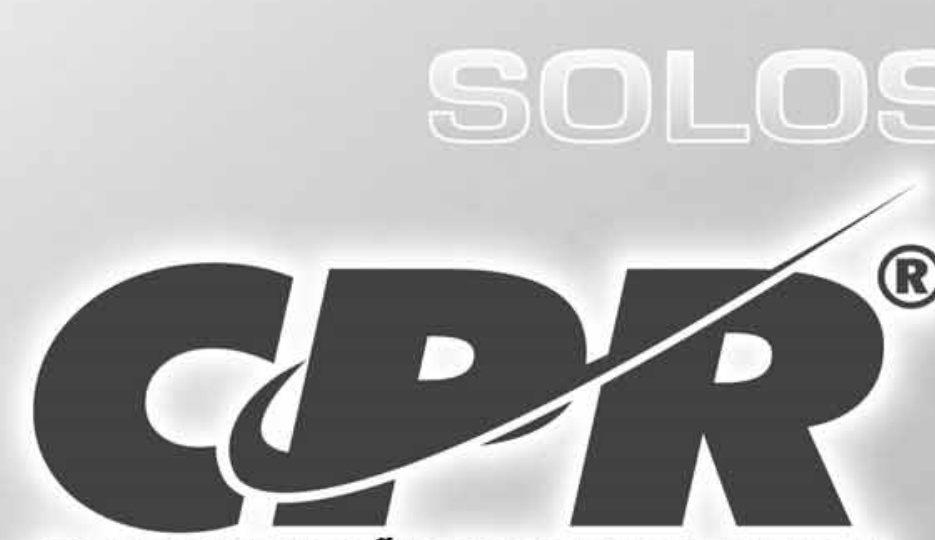

CONSOLIDAÇÃO PROFUNDA RADIAL

\section{O MAIS RÁPIDO E EFETIVO TRATAMENTO PARA SOLOS MOLES}

Processo de adensamento de solo mole, eficientemente controlado, monitorando-se o grau de consolidação desejado.

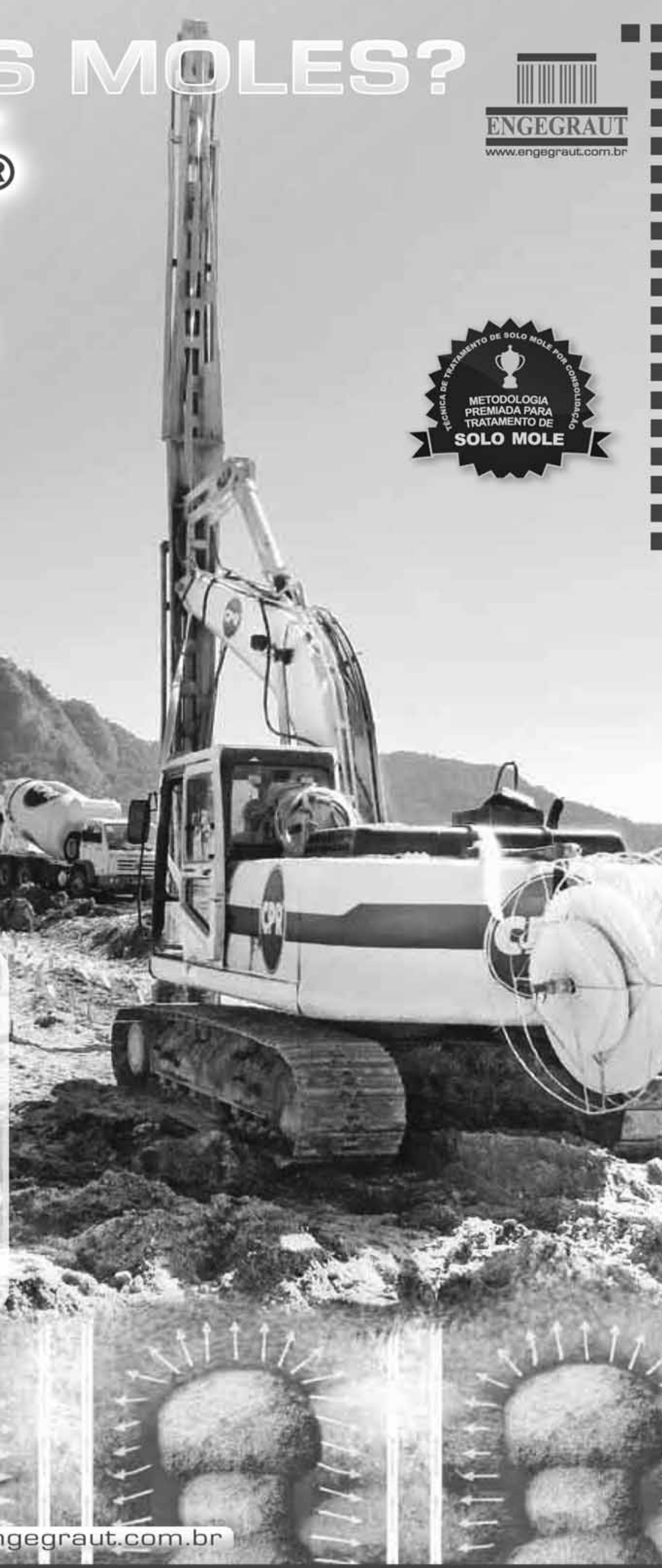



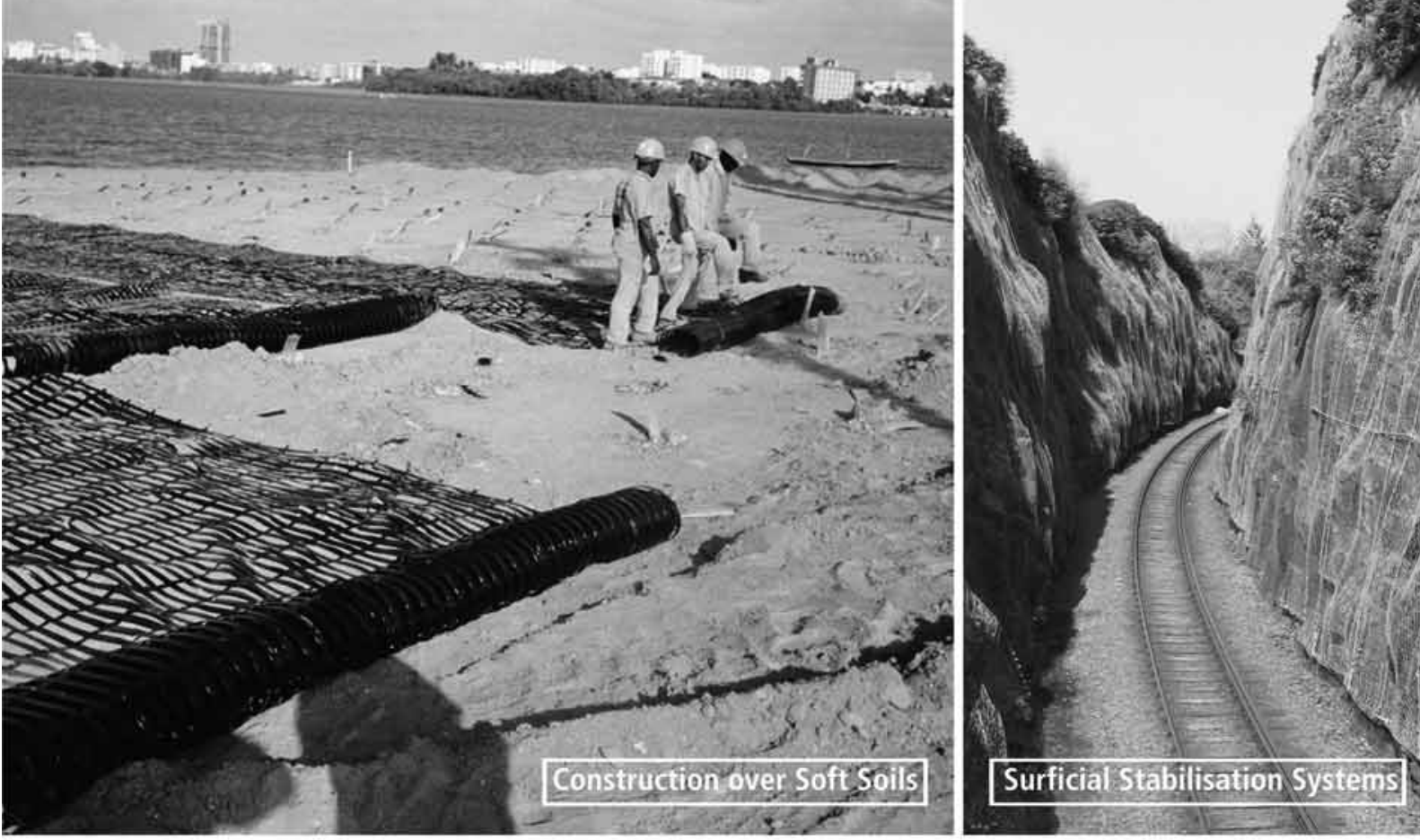

\section{SOILS AND ROCKS PROBLEMS? WE

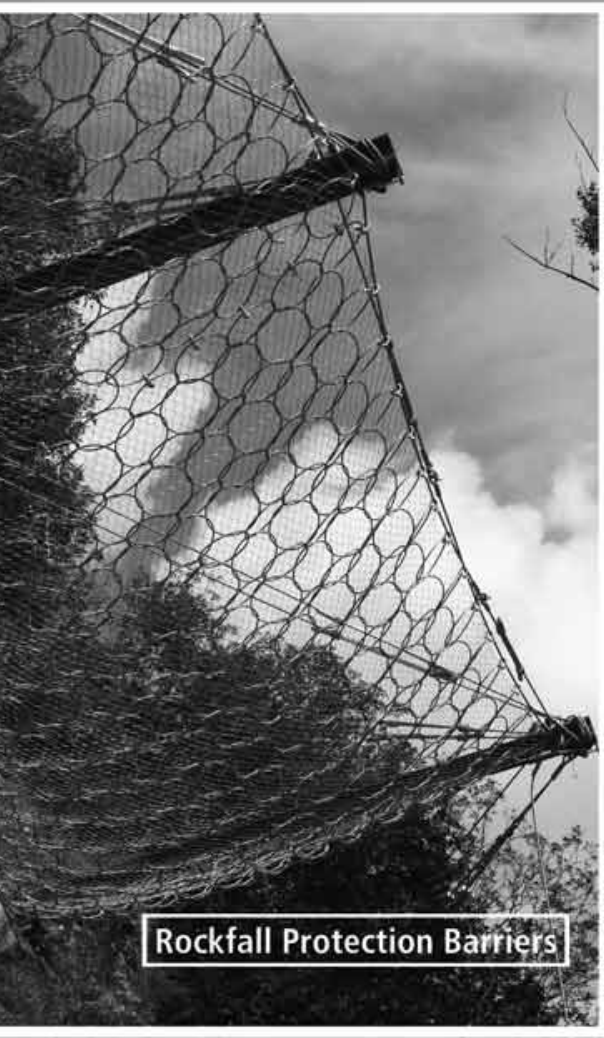

BRASIL

Phone: 55 (11) 4525-5000

Fax: 55 (11) 4599-4275

maccaferri@maccaferri.com.br

www.maccaferri.com.br
PORTUGAL

Phone: (351) 218968282

Fax: (351) 218968078

portugal@abianchini.pt

www.abianchini.es

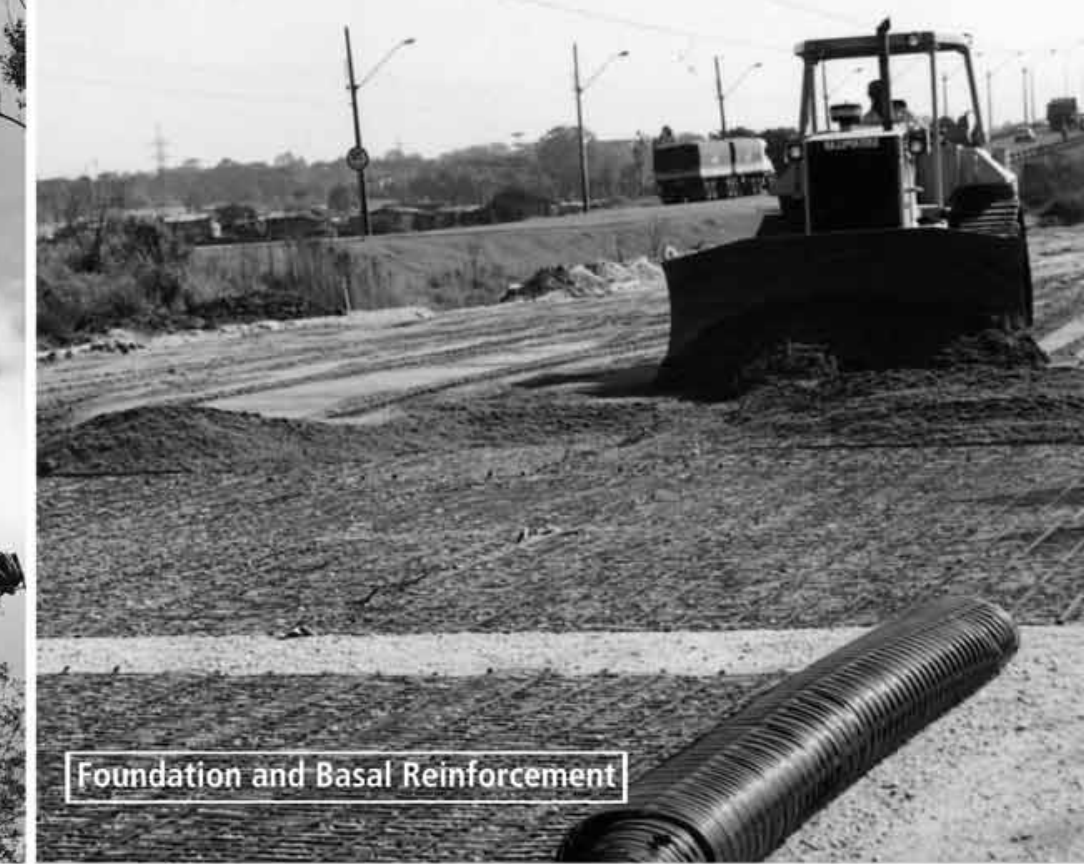

\section{MACCAFERRI}

Engineering a better solution 


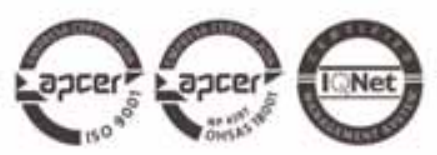

\section{Tecnasol}

\section{Geotechnics and Foundation Engineering}

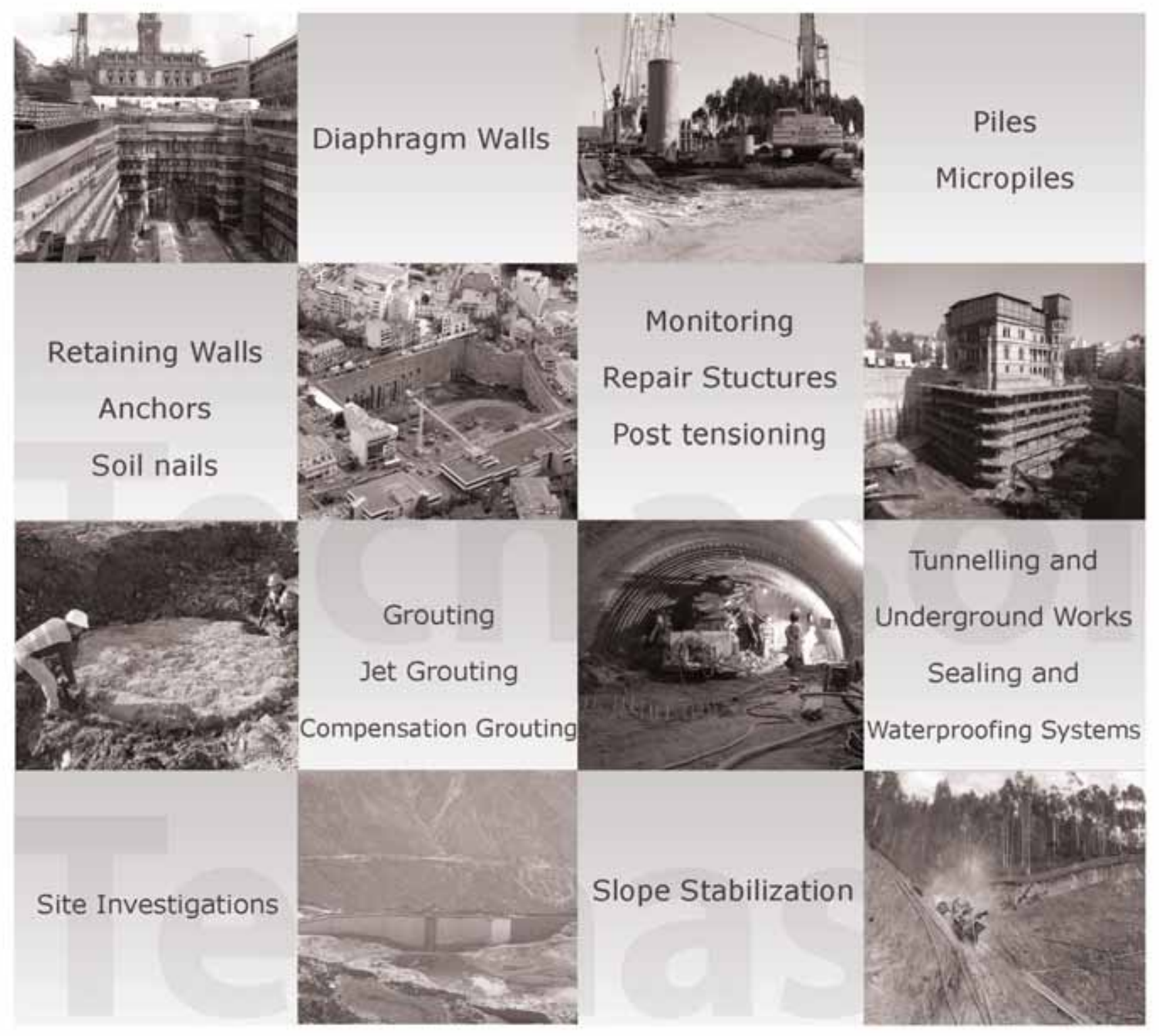

HEAD OFFICE

Estrada do Seminário, 4 - Alfragide

2610 - 171 Amadora - PORTUGAL

Tel. 00351214759000 / Fax 00351214759500

Madrid

Calle Rodriguez Marin, No $881^{\circ}$ Dcha

28016 Madrid - ESPANHA

Tel. 0034917450364 / Fax 0034914113187

\section{Angola}

Rusa Alameda Van-Dûnem, n, 0265 R/c

Lwanda - ANGOLA

Tel. 00244222443559 / Fax 00244222448843

\section{Porto}

Rua Eng. Ferreira Dias, no $1612^{\circ}$ Andar

4100-247 Porto - PORTUGAL.

Tel. $00351226167460 /$ Fax 00351226167469

\section{Barcelona}

Calle Comte d' Urgell, 204-20B 5,0 A

08036 Barceliona - ESPANHA

Tei, 0034934190452 / Fax 0034934190416
Madeira

Rampa dos Piornais, n.0 5 - Sala 1

9000-248 Funchal - PORTUGAL

Tel. 00351291221033 / Fax 0035129122 1034

Sevilha

Poligono Industrial de Guadalquivir, C/ Artesania, 3 41120 Gelves (Sevilla) - ESPANHA

Tel, 0034955762833 / Fax 0034955761175 


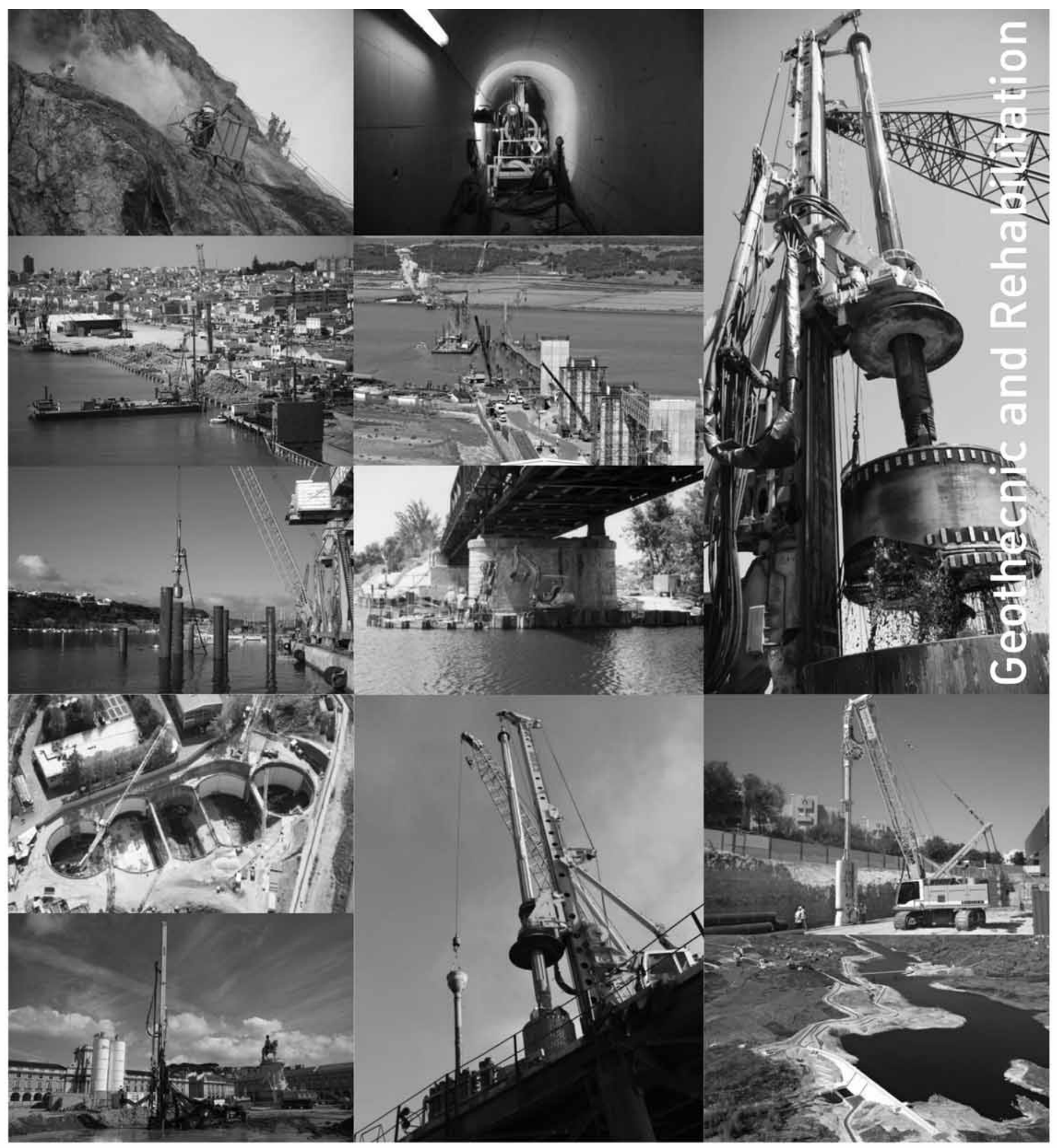

\section{TITEIXEIRA DUARTE \\ ENGENHARIA E CONSTRUÇŌES, S.A.}

- Head Office

Lagoas Park - Edificio 2

2740-265 Porto Salvo - Portugal

Tel.:(+351) 217912300

Fax: $(+351) 217941120 / 21 / 26$

- Angola

Alameda Manuel Van Dunen 316/320 - A

Caixa Postal 2857 - Luanda

Tel.:1+34] 915550903

Fax: $(+34) 915972834$
- Algeria

Parc Miremont - Rua A. №136 - Bouzareah

16000 Alger

Tel.:(+213) 21936283

Fax: $(+213) 21936566$

- Brazil

Rua Iguatemi, $n^{0} 488-14^{\circ}$ - Conj. 1401 CEP 01451 - 010 - Itaim Bibi - São Paulo

Tel.: (+55) 1121445700

Fax: (+55) 1121445704
- Spain

Avenida Alberto Alcocer, $n^{0} 24-7^{\circ} \mathrm{C}$ 28036 Madrid

Tel.:(+34) 915550903

Fax: $(+34) 915972834$

- Mozambique

Avenida Julyus Nyerere, 130 - R/C

Maputo

Tel.:(+258) 21491401

Fax: $(+258) 21491400$ 


\section{whr. cenor.pt}
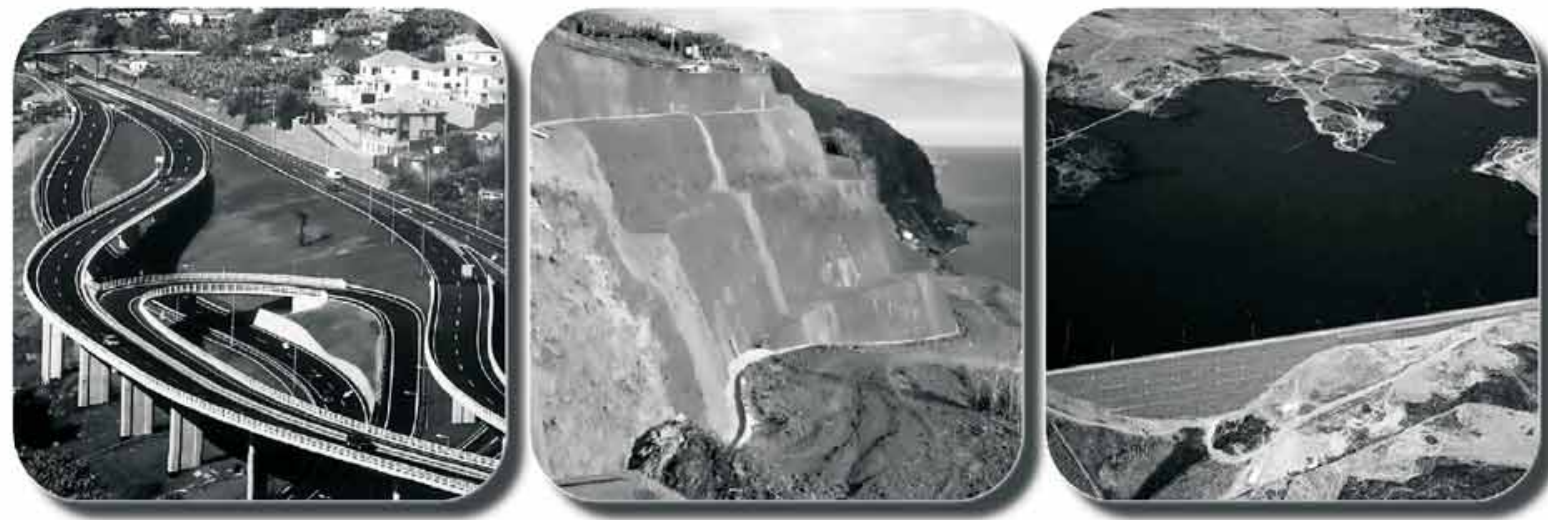

Geology - Geotechnics - Supervision of Geotechnical WoRKS
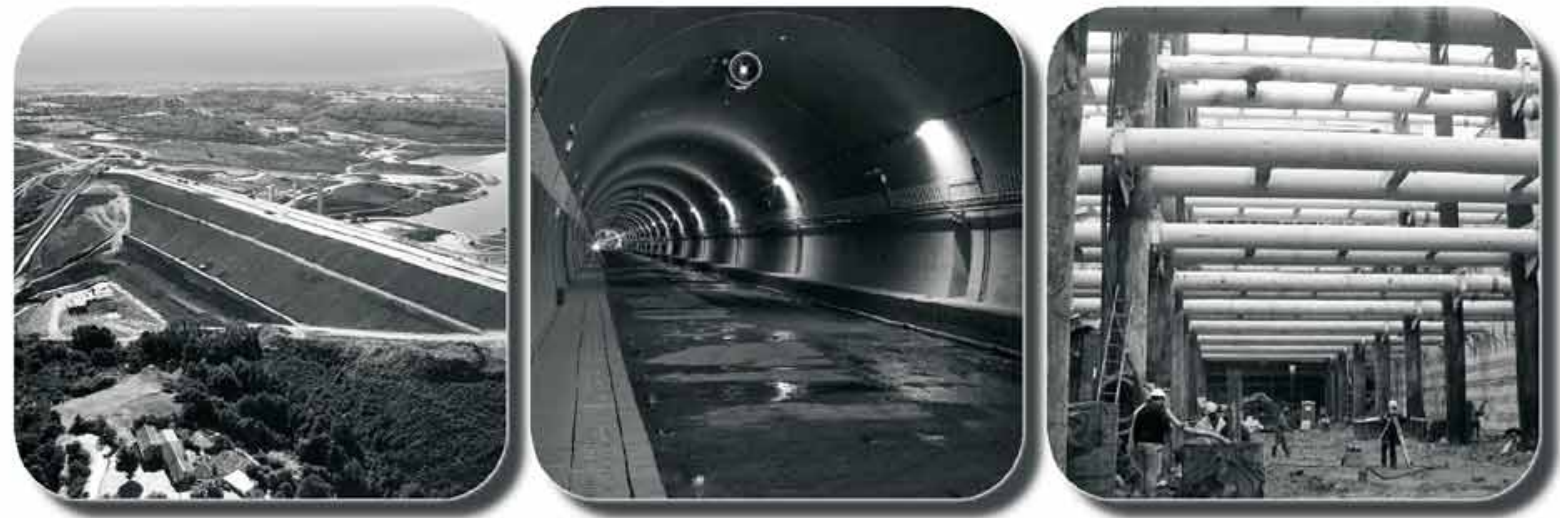

EMBANKMENT DAMS - UNDERGROUND WORKS - RETAINING STRUCTURES
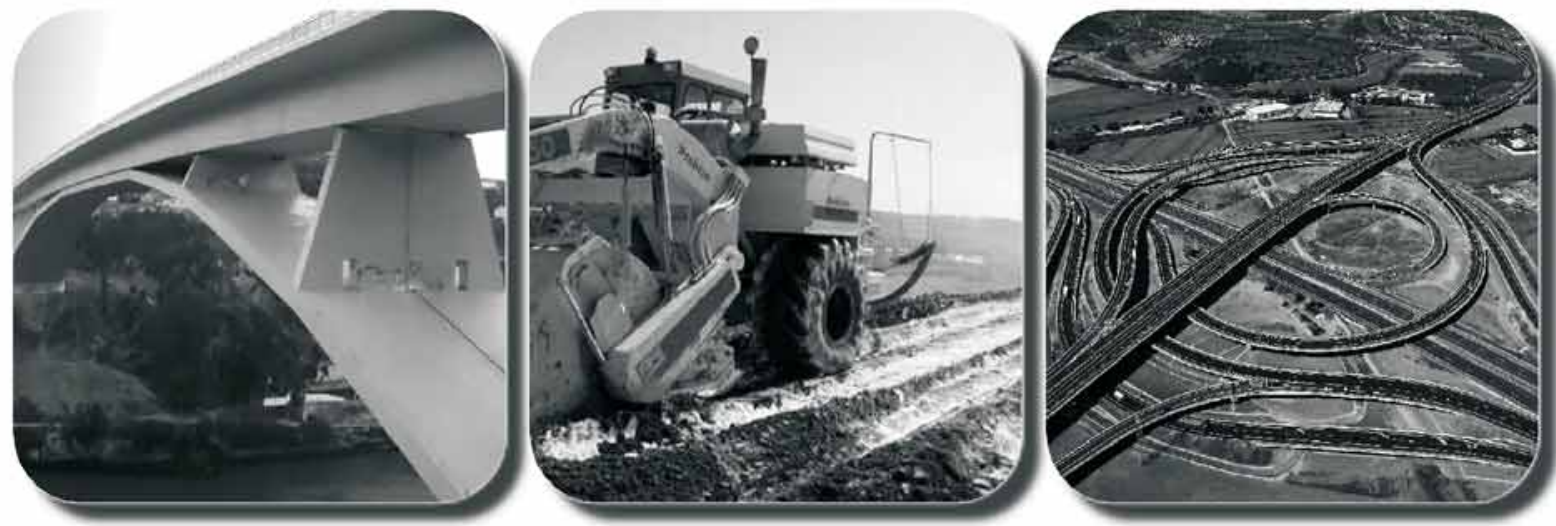

SPECIAL FOUNDATIONS - SOIL IMPROVEMENT - GEOMATERIALS

CENORGROUP

PORTUGAL, ANGOLA, ALGERIA, MOROCCO, ROMANIA, TIMOR

CENORGEO - Engenharia Geọtécnica, Lda.

Rua das Vigias, 2. Piso 1 Parque das Naçōes 1990-506 LISBOA . PORTUGAL

T. +351.218437300 F. +351.218437301 cenorgeolacenor.pt 


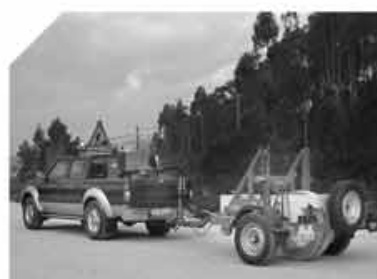

$>$ Prospecção Geotécnica

Site Investigation

$>$ Consultoria Geotécnica

Geotechnical Consultancy

$>$ Obras Geotécnicas

Ground Treatment-Construction Services

$>$ Controlo e Observação

Field Instrumentation Services and Monitoring Service

> Laboratório de Mecânica de Solos

Soil and Rock Mechanics Laboratory

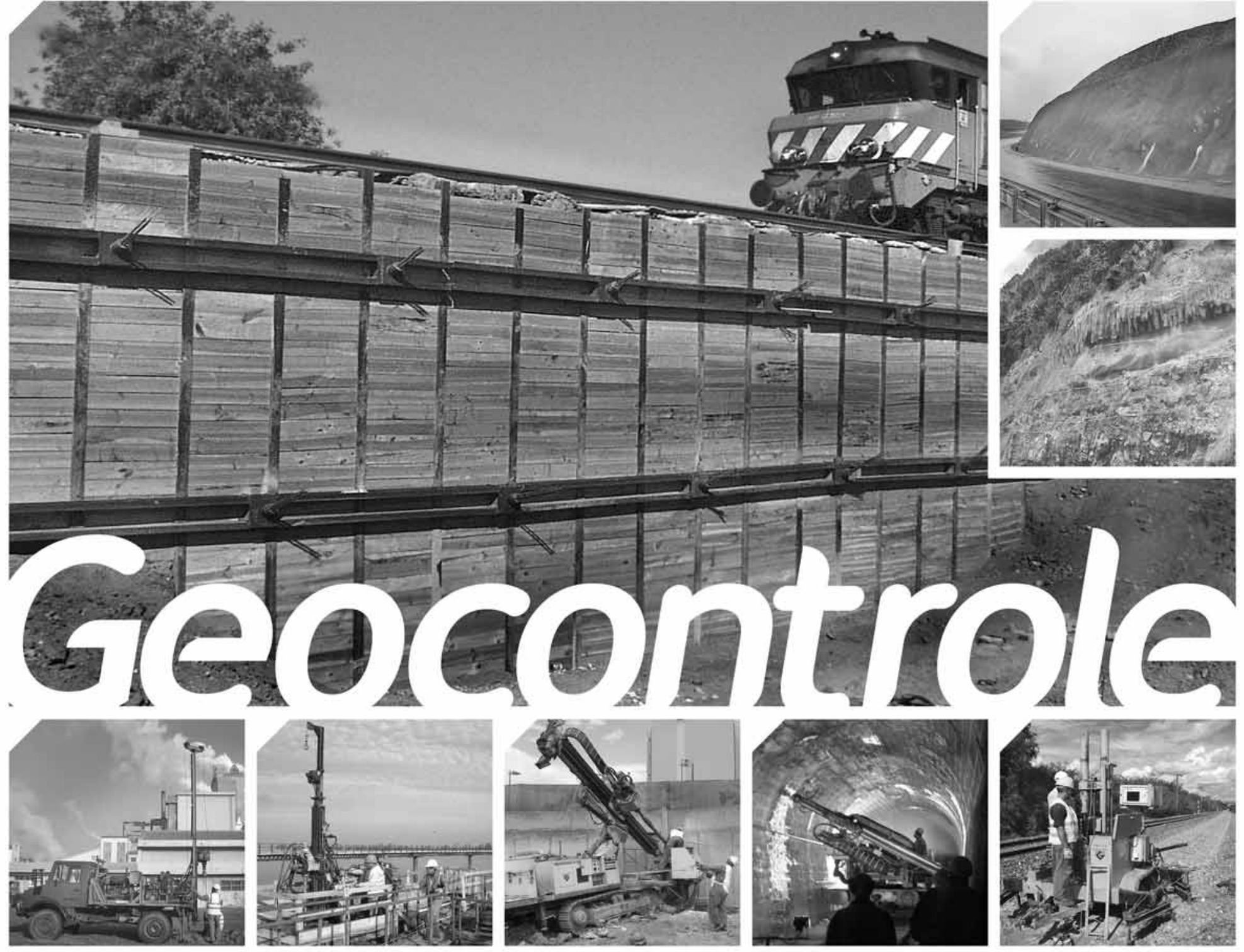




\section{tgeotecnia}

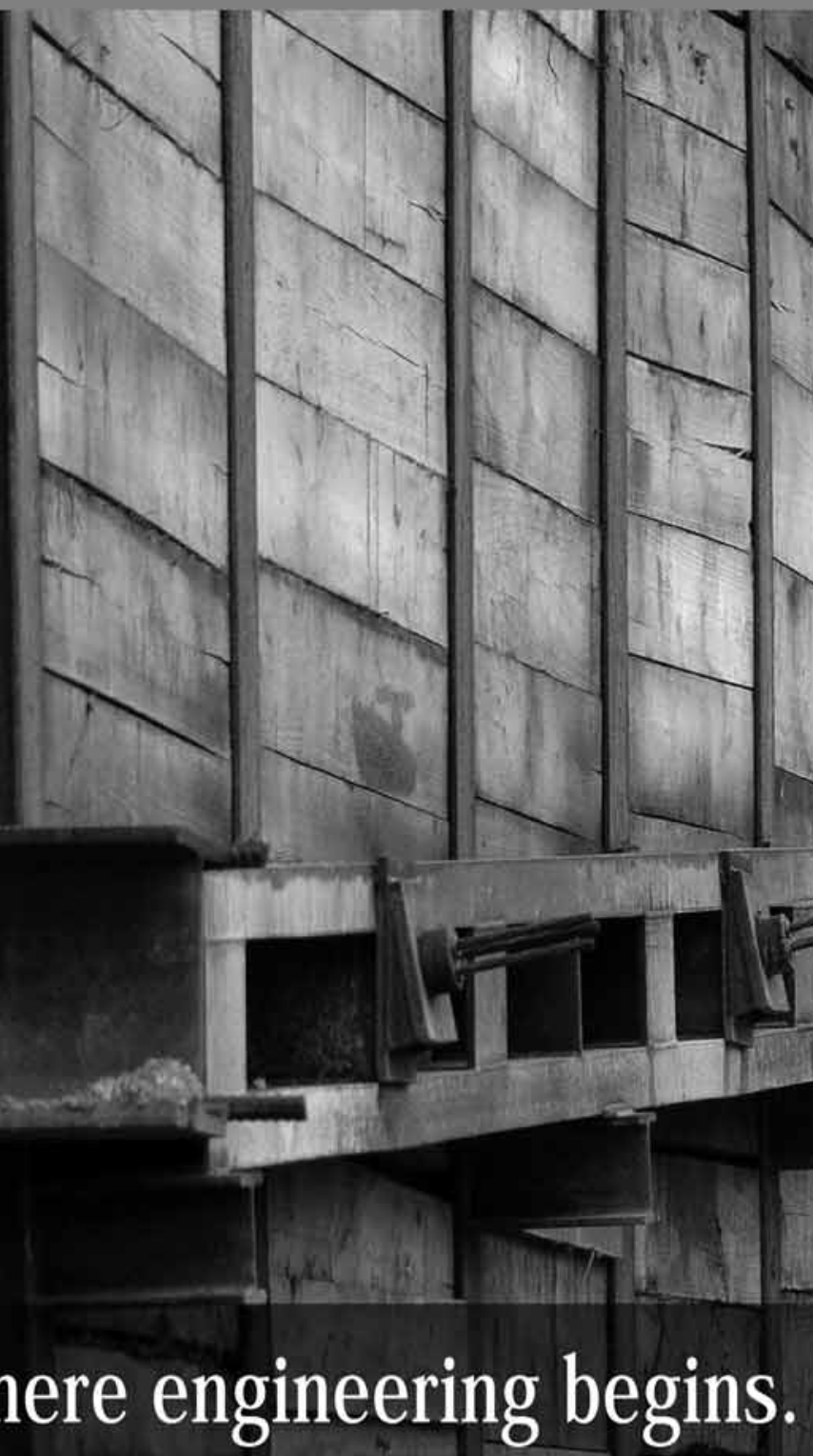

\section{Where engineering begins.}

Behind a great work there's always a great company.

tgeotecnia enters in national and Spanish market with a wide range of solutions, with state of the art technology and qualified means necessaries to engage geotechnical studies, projects and works.

Currently, tgeotecnia is specialised in all kinds of work, from geologic-geotechnical studies and project development to slope stabilisation, reinforcement, soil treatment and special foundations.

The works carried out and client satisfaction, as well as the growing number of projects, are the proof that it is worth making innovation the lever of development.

\section{tgeotecnia}

In the origin of construction
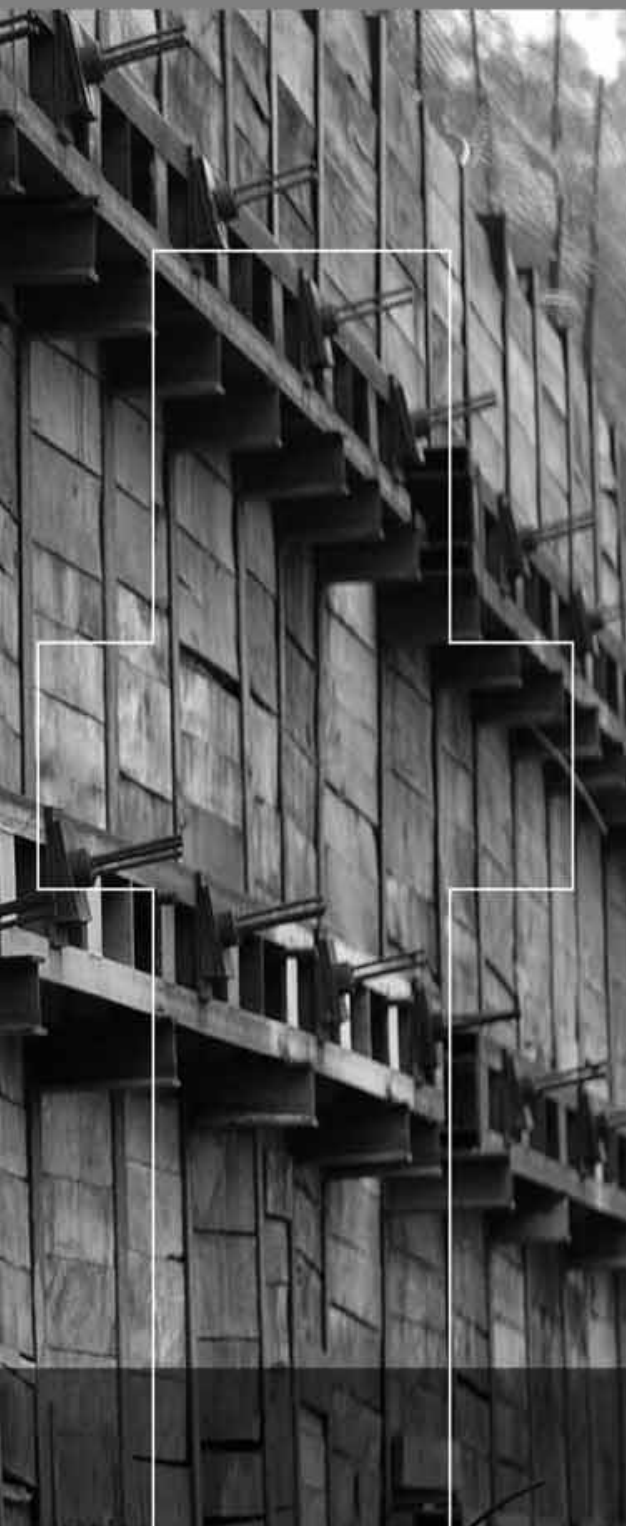

a dst group company 


\section{ENGINEERING AND ENVIRONMENTAL CONSULTANTS}
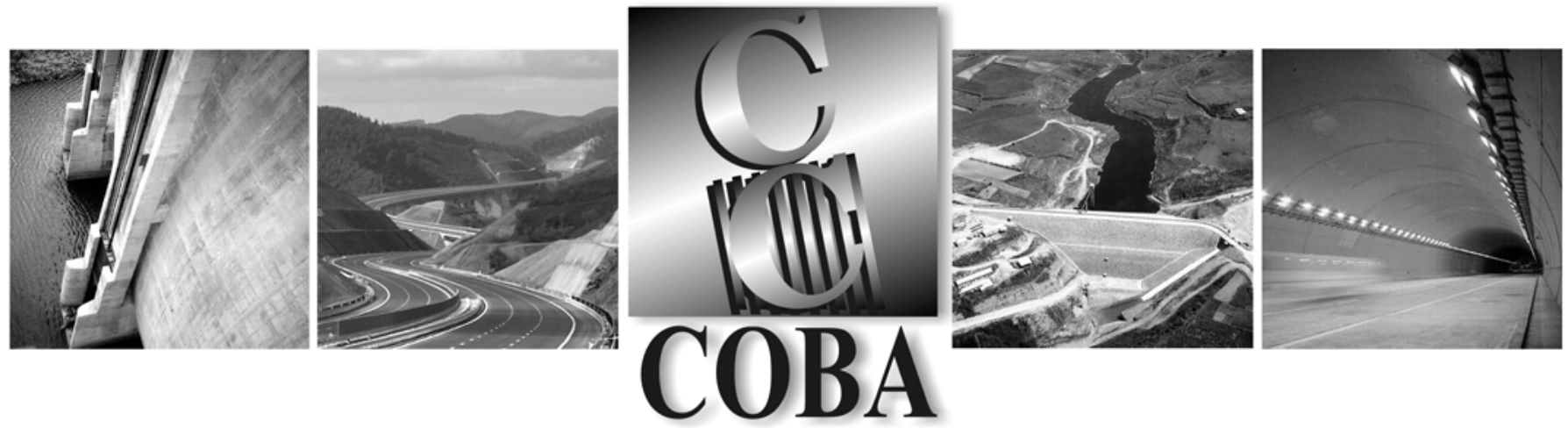

\section{GEOLOGY AND GEOTECHNICS}

Hydrogeology • Engineering Geology • Rock Mechanics • Soil Mechanics • Foundations and Retaining Structures - Underground Works - Embankments and Slope Stability Environmental Geotechnics • Geotechnical Mapping
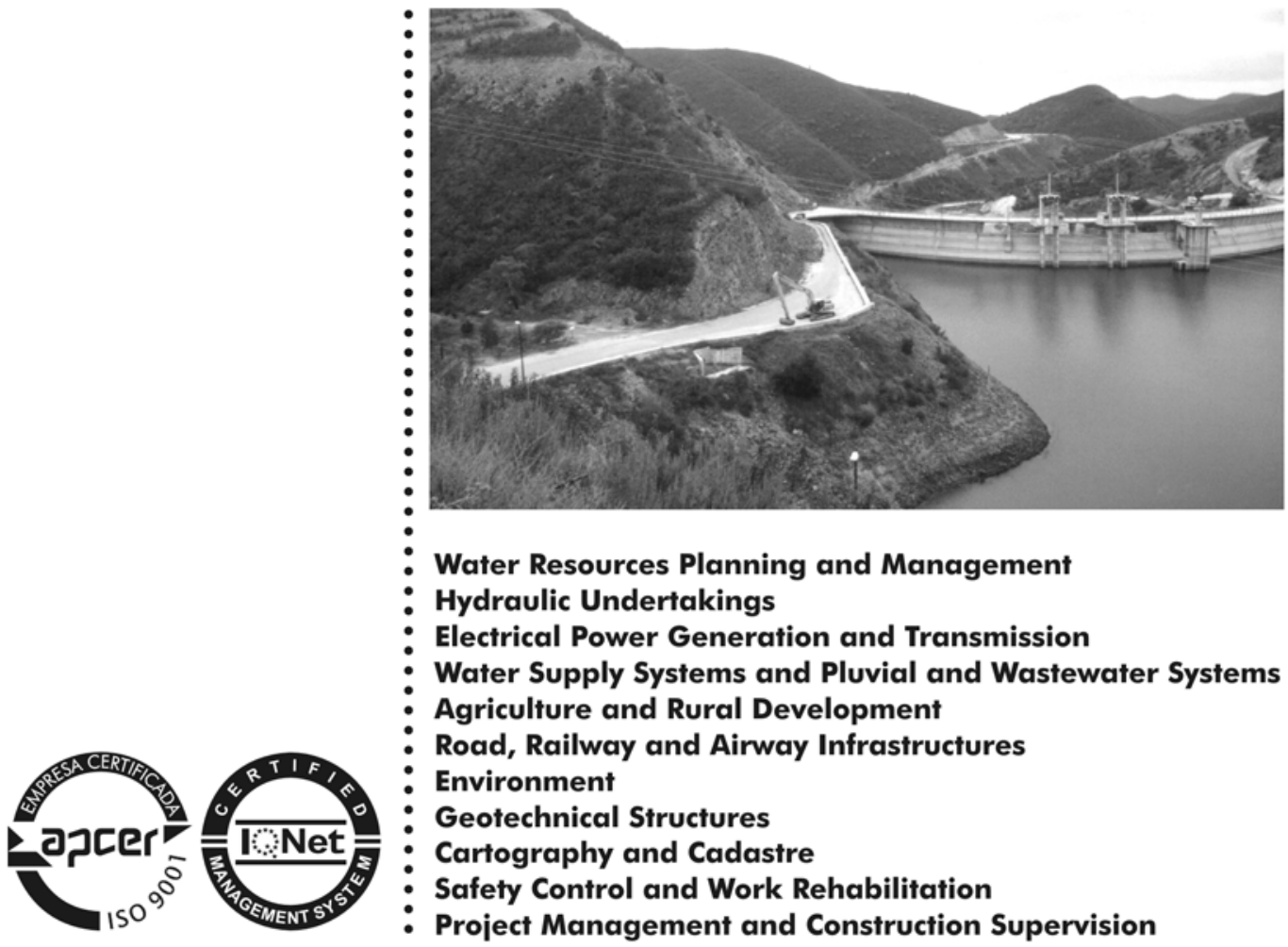

PORTUGAL

CENTER AND SOUTH REGION

Av. 5 de Outubro, 323

Tel.: (351) 210125000 , (351) 217925000

Fax: (351) 217970348

Fax: $(351) 217970348$

E-mail: coba@coba.pt

www.coba.p

Av. Marquês de Tomar, 9, $6^{\circ}$.

1050-152 LISBOA

Tel.:(351) 217925000

Fax:(351) 213537492

NORTH REGION

Rua Mouzinho de Albuquerque, $744,1^{\circ}$.

4450-203 MATOSINHOS

Tel:(351) 229380421

Tel: (351) 22938042

E-mail: engico@engico.pt
ANGOLA

Praceła Farinha Leiłão, edificio $n^{\circ} 27,27-\mathrm{A}-2^{\circ}$ Dło Bairro do Maculusso, LUANDA

Tel./Fax: (244) 222338513

Cell: (244) 923317541

E-mail: coba-angola@netcabo.co.ao

MOZAMBIQUE

Pestana Rovuma Hotel. Centro de Escritórios.

Rua da Sé n'114. Piso 3, MAPUTO

Tel./Fax: (258) 21328813

Cell:(258) 824099605

E-mail: coba.mz@tdm.co.mz

ALGERIA

09, Rue des Frères Hocine

EI Biar - 16606, ARGEL

Tel.: (213) 21922802

Fax: (213) 21922802

E-mail: coba.alger@gmail.com
BRAZIL

Rio de Janeiro

COBA Lłd. - Rua Bela 1128

Sáo Cristóvão

20930-380 Rio de Janeiro R

Tel.: (55 21) 35150101

Fax: (55 21) 25801026

Fortaleza

Av. Senador Virgilio Távora 1701, Sala 403

Aldeota - Fortaleza CEP 60170 - 251

Tel.: $(5585) 32611738$

Tel.: $\left(\begin{array}{l}55 \\ \text { F } 85\end{array}\right) 32611738$
Fax: $(5585) 32615083$

Fax: (55 85) 32615083

UNITED ARAB EMIRATES

Corniche Road - Corniche Tower - 5th Floor - 5B P. O. Box 38360 ABU DHABI

Tel.: (971) 26270088

Fax: (971) 26270087 


\section{STATIC LOAD TESTING HYDRODYNAMIC EXPANSION CELLS ${ }^{\circledR}$}

\section{ELIMINATES REACTION SYSTEM}

- Ideal for any load capacity.

- Cost savings, safety and speed in execution.

- Recommended for all types of foundations.

- Worldwide pioneer in bidirectional static load testing.

" 44 years developing advanced technologies, intelligent and creative solutions in the field of soil engineering."

\section{REINFORCEMENT OF FOUNDATIONS ARCOS MICROPILES:}

- Ideal for strengthening of foundations and pile driving in hard to reach places.

- Cost savings, safety and speed in execution. 


\section{Instructions to Authors}

\section{Category of the Papers}

Soils and Rocks is the scientific journal edited by the Brazilian Association for Soil Mechanics and Geotechnical Engineering (ABMS) and the Portuguese Geotechnical Society (SPG). The journal is intended to the divulgation of original research works from all geotechnical branches.

The accepted papers are classified either as an Article paper, a Technical Note, a Case Study, or a Discussion according to its content. An article paper is an extensive and conclusive dissertation about a geotechnical topic. A paper is considered as a technical note if it gives a short description of ongoing studies, comprising partial results and/or particular aspects of the investigation. A case study is a report of unusual problems found during the design, construction or the performance of geotechnical projects. A case study is also considered as the report of an unusual solution given to an ordinary problem. The discussions about published papers, case studies and technical notes are made in the Discussions Section.

When submitting a manuscript for review, the authors should indicate the category of the manuscript, and is also understood that they:

a) assume full responsibility for the contents and accuracy of the information in the paper;

b) assure that the paper has not been previously published, and is not being submitted to any other periodical for publication.

\section{Manuscript Instructions}

Manuscripts must be written in English. The text is to be typed in a word processor (MS Word or equivalent), using ISO A4 page size, left, right, top, and bottom margins of $25 \mathrm{~mm}$, Times New Roman 12 font, and line spacing of 1.5. All lines and pages should be numbered. The text should be written in the third person.

The fist page of the manuscript is to include the title of the paper in English, followed by the names of the authors with the abbreviation of the most relevant academic title. The affiliation, address and e-mail is to be indicated below each author's name. An abstract of 200 words is to be written in English after the author's names. A list with up to six keywords at the end of the abstract is required.

Although alteration of the sequence and the title of each section may be required, it is suggested that the text contains the following sections: Introduction, Material and Methods, Results, Discussions, Conclusion, Acknowledgements, References and List of Symbols. A brief description of each section is given next.

Introduction: This section should indicate the state of the art of the problem under evaluation, a description of the problem and the methods undertaken. The objective of the work is to be clearly presented at the end of the section.

Materials and Methods: This section should include all information needed to the reproduction of the presented work by other researchers.

Results: In this section the data of the investigation should be presented in a clear and concise way. Figures and tables should not repeat the same information.

Discussion: The analyses of the results should be described in this section. Conclusions: The text of this section should be based on the presented data and in the discussions.
Acknowledgenments: If necessary, concise acknowledgements should be written in this section.

References: References to other published sources are to be made in the text by the last name(s) of the author(s), followed by the year of publication, similarly to one of the two possibilities below:

"while Silva \& Pereira (1987) observed that resistance depended on soil density" or "It was observed that resistance depended on soil density (Silva \& Pereira, 1987)."

In the case of three or more authors, the reduced format must be used, e.g.: Silva et al. (1982) or (Silva et al., 1982). Two or more citations belonging to the same author(s) and published in the same year are to be distinguished with small letters, e.g.: (Silva, 1975a, b, c.). Standards must be cited in the text by the initials of the entity and the year of publication, e.g.: ABNT (1996), ASTM (2003).

Full references shall be listed alphabetically at the end of the text by the first author's last name. Several references belonging to the same author shall be cited chronologically. Some examples are listed next:

Papers: Bishop, A.W. \& Blight, G.E. (1963) Some aspects of effective stress in saturated and unsaturated soils. Géotechnique, v. 13:2, p. 177197.

Books: Lambe, T.W \& Whitman, R.V. (1979) Soil Mechanics, SI Version, $2^{\text {nd }}$ ed. John Wiley \& Sons, New York, p. 553.

Book with editors: Sharma, H.D.; Dukes, M.T. \& Olsen, D.M. (1990) Field measurements of dynamic moduli and Poisson's ratios of refuse and underlying soils at a landfill site. Landva A. \& Knowles, G.D. (eds) Geotechnics of Waste Fills - Theory and Practice, American Society for Testing and Materials - STP 1070, Philadelphia, p. 57-70.

Proceedings (printed matter or CD-ROM): Jamiolkowski, M.; Ladd, C.C.; Germaine, J.T \& Lancellotta, R. (1985) New developments in field and laboratory testing of soils. Proc. $11^{\text {th }}$ Int. Conf. on Soil Mech. and Found. Engn., ISSMFE, San Francisco, v. 1, pp. 57-153.(specify if CD $\mathrm{ROM})$

Thesis and dissertations: Lee, K.L. (1965) Triaxial Compressive Strength of Saturated Sands Under Seismic Loading Conditions. PhD Dissertation, Department of Civil Engineering, University of California, Berkeley, $521 \mathrm{p}$.

Standards: ASTM (2003) Standard Test Method for Particle Size Analysis of Soils - D 422-63. ASTM International, West Conshohocken, Pennsylvania, USA, 8 p.

Internet references: Soils and Rocks available at http://www.abms. com.br.

On line first publications must also bring the digital object identifier (DOI) at the end.

Figures shall be either computer generated or drawn with India ink on tracing paper. Computer generated figures must be accompanied by the corresponding digital file (.tif, .jpg, .pcx, etc.). All figures (graphs, line drawings, photographs, etc.) shall be numbered consecutively and have a caption consisting of the figure number and a brief title or description of the figure. This number should be used when referring to the figure in text. Photographs should be black and white, sharp, high contrasted and printed on glossy paper.

Tables shall be numbered consecutively in Arabic and have a caption consisting of the table number and a brief title. This number should be used when referring to the table in text. Units should be indicated in the first line of the table, below the title of each column. Abbreviations should be avoided. Column headings should not be abbreviated. When applicable, the units should come right below the corresponding column heading. Any necessary explanation can be placed as footnotes.

Equations shall appear isolated in a single line of the text. Numbers identifying equations must be flush with the right margin. International System (SI) units are to be used. The symbols used in the equations shall be listed in the List of Symbols. It is recommended that the used symbols 
be in accordance with Lexicon in 8 Languages, ISSMFE (1981) and the ISRM List of Symbols.

The text of the submitted manuscript (including figures, tables and references) intended to be published as an article paper or a case history should not contain more than 30 pages formatted according to the instructions mentioned above. Technical notes and discussions should have no more than 15 and 8 pages, respectively. Longer manuscripts may be exceptionally accepted if the authors provide proper explanation for the need of the required extra space in the cover letter.

\section{Discussion}

Discussions must be written in English. The first page of a discussion paper should contain:

- The title of the paper under discussion in the language chosen for publication;

- Name of the author(s) of the discussion, followed by the position, affiliation, address and e-mail. The discusser(s) should refer himself (herself, themselves) as "the discusser(s)" and to the author(s) of the paper as "the author(s)".

Figures, tables and equations should be numbered following the same sequence of the original paper. All instructions previously mentioned for the preparation of article papers, case studies and technical notes also apply to the preparation of discussions.

Editorial Review

Each paper will be evaluated by reviewers selected by the editors according to the subject of the paper. The au- thors will be informed about the results of the review process. If the paper is accepted, the authors will be required to submit a version of the revised manuscript with the suggested modifications. If the manuscript is refused for publication, the authors will be informed about the reasons for rejection. In any situation comprising modification of the original text, classification of the manuscript in a category different from that proposed by the authors, or refusal for publication, the authors can reply presenting their reasons for disagreeing with the reviewers' comments

\section{Submission}

The author(s) must submit for review:

1. A hard copy of the manuscript to Editors - Soils and Rocks, Av. Prof. Almeida Prado, 532 - IPT, Prédio 54 - DEC/ABMS, 05508-901 São Paulo, SP, Brazil. The first page of the manuscript should contain the identification of the author(s), or

2. The digital file of the manuscript, omitting the authors' name and any information that eventually could identify them, should be sent to abms@ipt.br. The following must be written in the subject of the e-mail message: "Paper submitted to Soils and Rocks". The authors' names, academic degrees and affiliations should be mentioned in the e-mail message. The e-mail address from which the digital file of the paper was sent will be the only one used by the editors for communication with the corresponding author.

\section{Follow Up}

Authors of manuscripts can assess the status of the review process at the journal website (www.soilsandrocks.com.br) or by contacting the ABMS secretariat. 


\section{Volume 36, N. 3, September-December 2013 Table of Contents}

\section{ARTICLES}

Universal Classification for the Use of Lateritic Soils in Low Cost Durable Pavements

J.K.G. Rodrigues, P. Reiffsteck, J.C. Auriol, M. Ndiaye

Dewatering Sludge in Geotextile Closed Systems: Brazilian Experiences

M.G.A. Guimarães, D.C. Urashima

Surprising Soil Behaviour in Soil Sampling

G.M.F. Jannuzzi, F.A.B. Danziger, I.S.M. Martins

Remediation Techniques Applied in Residual Clayey Soil (Oxisol) Contaminated by Diesel and Biodiesel

L.R.R. Meneghetti, A. Thomé, F. Schnaid, L.M. Colla

Behavior of Clay-Tire Mixtures Subjected to Undrained Monotonic Loading

H. Soltani-Jigheh, V. Marefat, A. Ersizad

Numerical Analysis of El-Agrem Concrete Face Rockfill Dam

B. Moussai

Numerical Analysis of Reinforcement Strains at Failure for Reinforced Embankments over Soft Soils

E.F. Ruiz, P.S. Hemsi, D.M. Vidal

\section{TECHNICAL NOTE}

Cadmium Transport Parameters in a Clayey Residual Soil with Different Values of Contaminant $\mathrm{pH}$

A. Thomé, E.P. Korf, R.S. Tímbola, N.C. Consoli 